
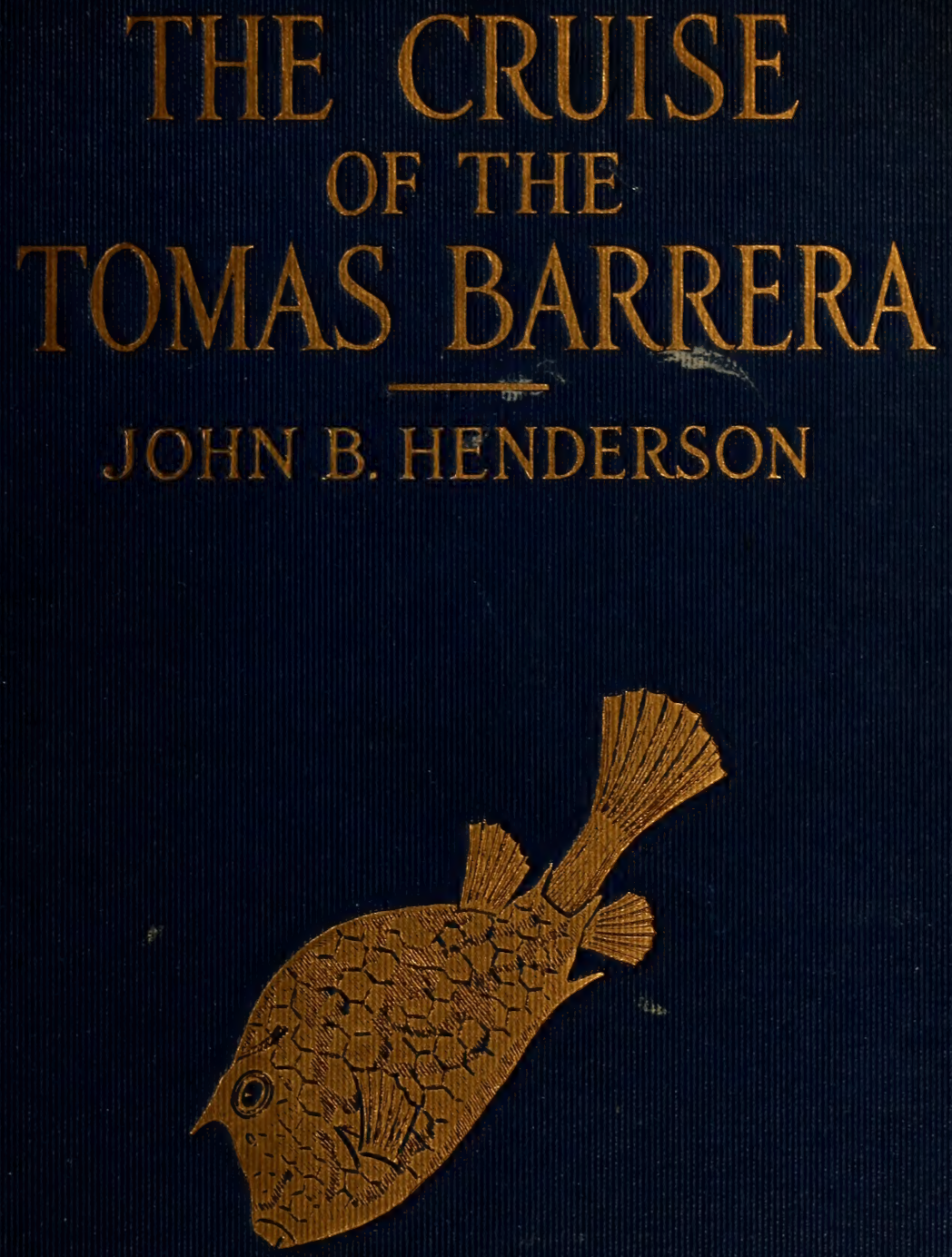


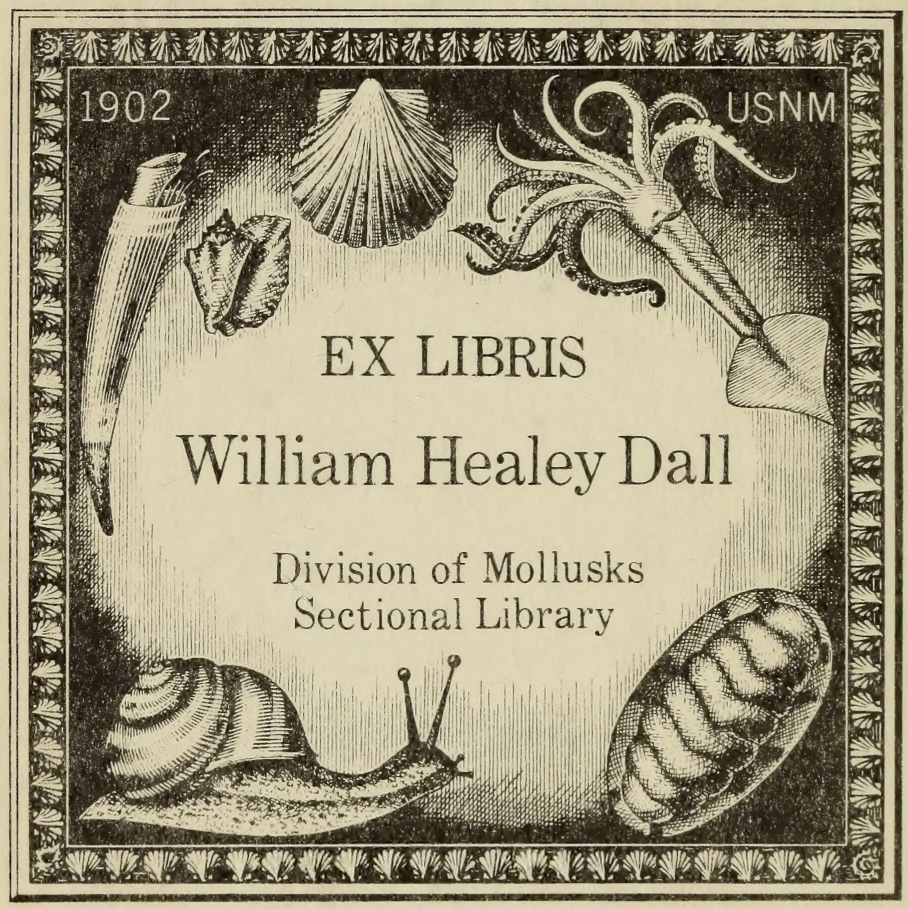


$\angle$ BARRERA.

Division of Mollusks

Sectional Library

Dr. Vivian Doe, will the archers compliments and regards. 






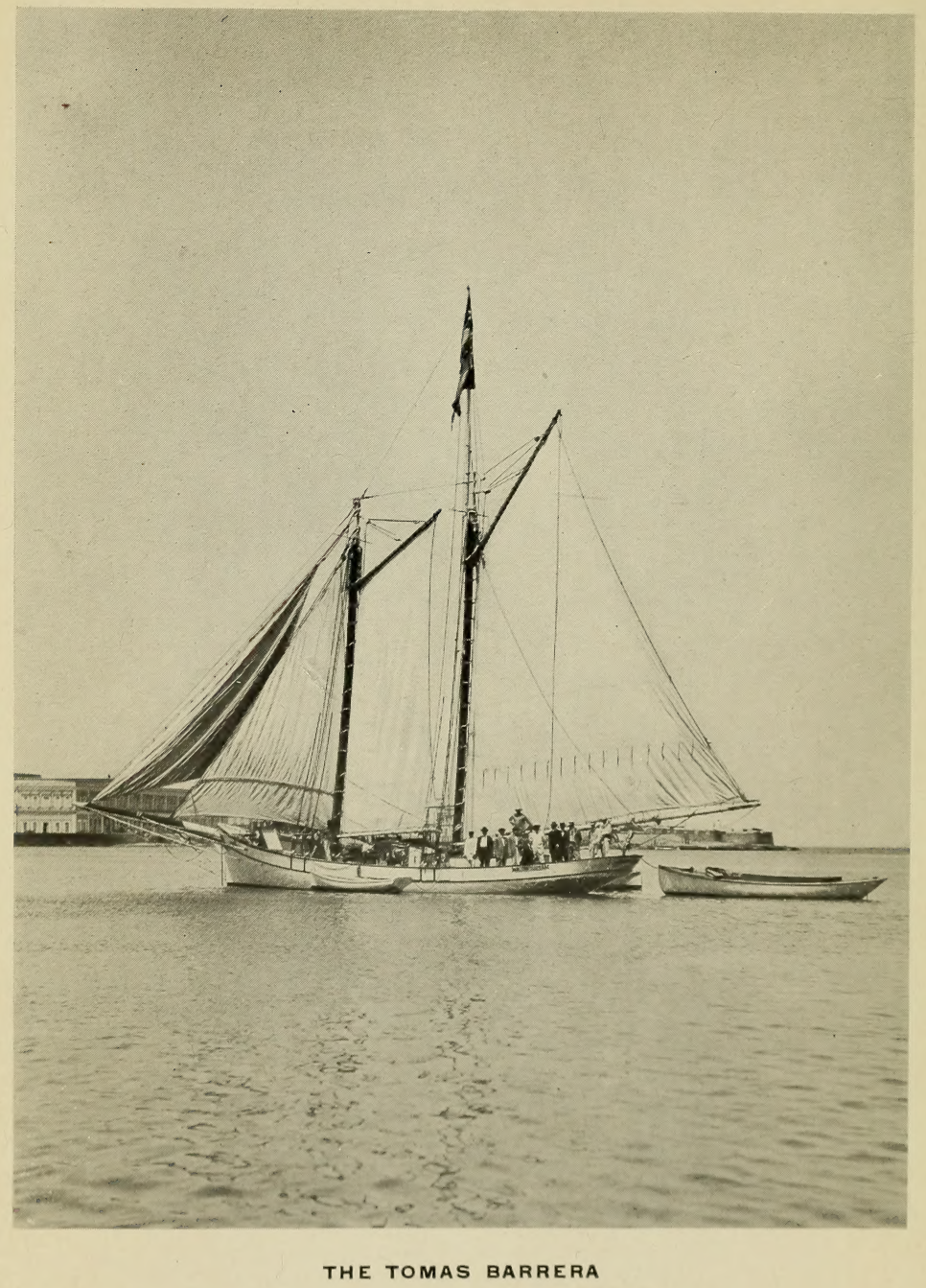

From a photograph by Rafael B. Santa Coloma 


\section{The Cruise of the}

\section{Tomas Barrera}

The Narrative of a Scientific Expedition to Western Cuba and the Colorados Reefs, with Observations on the Geology. Fauna, and Flora of the Region

\section{By}

\section{John B. Henderson}

Author of "Amerioan Diplomatic Questions"

With 36 Illustrations and Maps

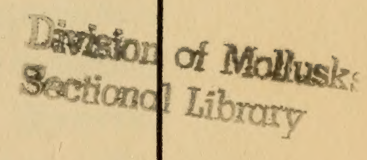

\section{G. P. Putnam's Sons} New York and London Tbe tknickerbocker Dress I9I 6

\section{SMITHSONIAN \\ JUN 081988}




\section{COPYRIGHT, I9I6}

BY

G. P. PUTNAM'S SONS

Tbe Tinickerbocker Dress, Wew 1gork 


\section{PREFACE}

$7 \mathrm{HE}$ following chapters are an expansion of a diary and field notes written every evening during our cruise. There are likely some errors in the conclusions set forth, for no student of nature is infallible. It is the province of each generation of naturalists to correct the mistakes of the past.

To all the members of the expedition-especially to Dr. Carlos de la Torre-and to various specialists of the U. S. National Museum staff, I am indebted for valuable assistance. To Mr. C. T. Simpson I owe thanks for the identification of plants. Finally I wish to express my gratitude to Dr. Bartsch for his keen interest as well as his aid.

The large amount of material collected by the expedition is now being critically studied and the results will eventually be published in the Smithsonian Reports.

Since the preparation of the manuscript, we have heard with much sorrow of the wreck of the 
Barrera at the Leña Keys during the hurricane of last August, with the loss of three of her crew. The same storm destroyed the house of the fine old man at Cape Cajon, and no trace of him or his family has been found. The family of the lightkeeper of "Roncali," at Cape San Antonio, who extended to us such cordial hospitality, were also killed by collapse of their house, and the wireless tower is destroyed.

J. B. H.

Washington, D. C.

January, I916. 


\section{CONTENTS}

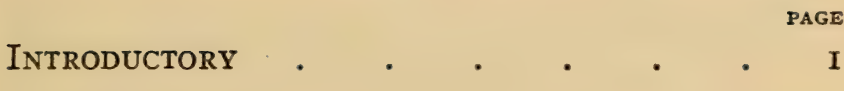
CHAPTER

I.-Overland to La Esperanza - I4 II.-LA EsPeranza • • • • $4 \mathrm{I}$ III.-Esperanza to Cayo Hutia • . 48 IV.-Cayo Hutia and the ReeF - • 55 V.-Santa Lucia to Azucar . . 69 VI.-PAN DE AZUCAR $\quad$. $\quad$. $\quad$. 79 VII.-Azucar to the Coast . . . 103 VIII.-Santa Lucia to Dimas . . II2 IX.-To Santa Rosia and Santa Maria . il 8 X.-Santa Maria to Los Arroyos . 125 XI.-Los Arroyos . . . . 137 XII.-Los Arroyos to Punta Colorado . I4I XIII.-Cape Colorado to Cape Cajon . 147 XIV.-Cape San Antonio . . . . 153 XV.-Leña Keys to Guadiana Bay . 212 


\section{vi CONTENTS}

CHAPTER PAGE XVI.-Overland From La Fe to Viñales . 215 XVII.-VIÑALES. • • • • • 224 XVIII.-SierRa dE Viñales • • . 234 XIX.-SAN Vicente Baños • • • 245 XX.-Esperanza to Cayo Levisa . 250 XXI.-La Mulata . • • • . 256 XXII.-Pan DE Guajaibon . . . 262 XXIII.-La Mulata to Bahia Honda • 287 XXIV.-Bahia Honda to Cabañas • . 294 XXV.-Cabañas $\quad$ • . . . 299 INDEX . . . . . . 315 


\section{ILLUSTRATIONS}

The Tomas Barrera . . . Frontispiece

Royal Palms along a Roadway • • 14

Ceiba tree on the Road from Pinar del Rio to Viñales . . . . . . ${ }_{1} 6$ ON the Way to Viñales . . . . 18

A Typical Mogote of the Viñales Region 22 Viñales and El Tumbadero . . . 26 Viñales . . . . . . . 28

Cove of Delight . . . . . $\quad 32$

Dr. Carlos de la Torre . . . . 38 La Chorrera . . . . . . 42 Spiny Lobster and Squirrel Fishes • $\quad 58$ M Coral Polyps . . . . . 60

Rock Beauty (In Color) . . . . 72 A Mogote near Viñales Showing Sierra Vegetation . . . . . . . 86 Cuban Todi (In Color) . . . . $\quad$. $\quad 92$ vii 
Balistes Vetula Linneds (In Color) • • 104 Mouse Fish (In Color) ' . . . . 126

A Shore Party about to Leave the Schooner 154 The Patron Collecting Sponges . . I6o Pylopagurus discoidalis in Dentalium Shell $\quad 178$ Cuban Trogon (In Color) . . . . 194 LA FÉ . . . . . . . 216

Typical Cuban Village in the Sierra COUNTRY . . . . . . . 220 The Cab of Martinez . . . . 224

Dos Hermanos. Sierra de Viñales in the BACKGROUND . . . . . . 226 The Tick-eating "Ani" Bird . . . 228 A Native Bohio in the Viñales Valley . 230 The Cuban Plow. Viñales Valley. Walls of West Face of El Tumbadero in BACKGROUND . . • . . 232

Portion of El Tumbadero, about 800 Feet Elevation . . . . • . 234 RodrigueZ AND THE "MAJA" . . . 236 La Puerta del Ancon . . . . 246 The Mimosa Tree at San Vicente Baño 248 
Costanera de San Vicente-South ElevaTION $. \quad . \quad . \quad . \quad . \quad . \quad .252$ Guajaibon • • . $\quad$ • . 262

The Guide “Pablo" . . . . . . . 286

Royal Palms '.

Ficus Trees along a Country Roadway . 302

\section{MAPS}

Diagrammatic Section across Pinar del Rio North AND South in about LongiTUDE OF VIÑLES, TO SHOW WARPING OF Strata and Subsequent Erosion - ilo

IDEALIZEd SKetch OF SHORE • . . I27

Cape San Antonio . . . . . . 154

Viñales Region . . . . . . . 224

Route to Gujaibon . . . . . 266

ROUTE MAP . . . . . At End 



\section{The Cruise of the "Tomas Barrera"}

\section{Introductory}

A SIX weeks' cruise along the northwest coast of Cuba and among the Colorados Reefs for study of the land and marine fauna and flora, and its salient geological features, was the outcome of an original plan for a single object only.

For some years, as opportunity offered, I had been making collections of marine mollusks in Southern Florida from shore stations to the hundred fathom line. This region of the Florida Keys is faunally Antillean, and the identification of the large amount of material secured necessitated a study of the entire marine molluscan fauna of the West Indies. There is no thoroughly satisfactory collection of these Antillean marine shells of moderate depths in the United States and doubt attaches to the identity of many of the species 
originally described by European authors. The types of these, that is to say, the actual specimens described, are in Europe, and their descriptions and figures are often inadequate and faulty. A real desideratum then was a full collection of Cuban marine mollusks to compare with those of Florida from similar depth zones.

In March, I9I4, I consulted with Doctor Carlos de la Torre in Havana about the details of such a collecting trip. In his opinion the richest field would be found among the Colorados Reefs of Western Cuba, extending from Cape San Antonio to Bahia Honda, where, within their living coral breakwaters, a large expanse of shallow protected sea would likely favor a flourishing marine life. An additional feature of interest attaching to this particular region lay in the fact that it is uncharted and to the naturalist almost unknown. Opportunity for some real exploration, and for possible discoveries of interest, would greatly enhance the pleasure of a visit to the Colorados, and we were delighted with the thought of untouched coral reefs, unvisited islands, and many hundred square miles of crystalline tropic waters. Besides all this, exceptional opportunities for shore work and 
collecting upon the northern slopes of the Sierra de los Organos would be presented,-localities of rich possibilities that had been denied us upon previous inland collecting trips, on account of their inaccessibility from the south or land side.

Dr. Torre found that one of a most attractive looking fleet of white fishing schooners, anchored under the walls of Cabañas fort, could be chartered. With great and unexpected generosity the owner, Raoul Mediavilla, placed the newest and best, the Tomas Barrera, at our disposal. This offer involving equally the generosity of her half owner, Gaspar Pellicer, brought to our use a splendid boat and crew, with a skipper-pilot thoroughly familiar with the waters we wished to explore. The owners positively declined to accept any charter price or remuneration whatever, leaving to us merely the cost of provisions.

Thus materialized our dreams of a naturalists' cruise in Cuban waters. It was like seeing burst into full flower a cherished plant one had long and tenderly nurtured.

With the ample proportions of the schooner and the possibilities of a much greater range of work than originally contemplated, Dr. Torre and I 
proceeded to enlarge the scope of the expedition by inviting other naturalists to join the party. Mr. George H. Clapp one of the directors of Carnegie Institute of Pittsburg, my enthusiastic companion of many collecting trips, was already preparing to leave for Havana by May Ist. Dr. Paul Bartsch, Curator of the Department of Marine Invertebrates of the National Museum at Washington, accepted an invitation to accompany us, and his connection with the expedition at once added new importance to the undertaking. Dr. Bartsch is a veteran collector of great energy and skill and is one of the best all-around field naturalists living. His chief object in joining the Barrera company was to make as extensive collections as possible of the entire fauna of the region and particularly for use in the exhibition series in the new National Museum building. An attempt is being made by the museum authorities, in the public exhibition series, to retain the precise colors of all specimens that must be kept in preservative fluid. Pigments have been found that are insoluble in alcohol, but the problem still confronts the preparators to employ the exact shades of color. Many of the marine creatures desired for exhibition purposes, 
possess such delicate shades of coloration that the most carefully taken color notes of the collector in the field fail to furnish the preparator with the exact data required for the high standard set by the museum. To meet this difficulty Dr. Bartsch proposed taking a skilled preparator along, who, with his paints and brushes, should be on hand ready to treat desirable specimens before their colors could fade. George W. Gill, of the museum staff, was detailed for this work.

An invitation was also accepted by Charles $T$. Simpson of Miami, Florida, to join us in Havana. He was a valuable addition to our company in that he is an expert in two specialties. He was formerly, for many years, connected with the Division of Mollusks in the Smithsonian at Washington and is a collector of wide experience. $\mathrm{He}$ is especially conversant with the land shells of the Antilles, gained by several collecting trips, with the writer, to Jamaica, Haiti, and Cuba. As a botanist, it may be said that his private grounds near Miami contain a greater collection of tropical plants and trees than is to be found in any botanical garden in the United States-a fact now claiming considerable attention by our Agricult- 
ural Department. $\mathrm{He}$ is an authority upon the Antillean flora.

The President of the Cuban Republic, Sr. Menocal, learning of our proposed expedition, took a lively interest in its success. He suggested that the expedition might be turned to some very practical uses by taking the opportunity to study conditions of food-fish life among the Colorados, to the end of better devising means for their protection and preservation. He asked to have accompany us the Havana Inspector of Fish, Sr. Manuel Lesmes. As an expert in all matters pertaining to the Cuban fisheries, we felt that he would be a most useful man on board. The President further directed an appropriation to meet certain expenses connected with the preservation of a series of all material collected for the University of Havana laboratories. To look after this and to assist in every way both in the field and in the daily preparation of the catch aboard, Dr. Torre detailed a university museum assistant, Victor J. Rodriguez, to accompany the party. Sr. Rodriguez proved to be one of our hardest workers and was always of the greatest assistance to the naturalists.

Dr. Carlos de la Torre, of the University of 
Havana, the Dean of Cuban naturalists and an authority upon all subjects dealing with Cuban natural history, was our most enthusiastic member -our guide, philosopher, and friend.

A large amount of collecting material was sent by the National Museum. There were four large copper tanks of alcohol of varying strengths, formalin, copper sulphate for "doping" the tide pools, the various narcotizing reagents for expanding and killing specimens requiring such treatment, apparatus for injecting vertebrates, an amazing quantity of wide-mouth bottles and jars, instruments for oceanographic work, and many articles of special use to collectors and preparators, all of which had been selected with great care by Dr. Bartsch. In addition to this we had brought from Miami a twenty-five foot Gurnet dory of excellent model, equipped with rotary pump and stationary sieves ranged outboard, a number of dredges of varying sizes and weights, and other special collecting apparatus. The launch was in charge of Capt. S. W. Greenlaw, whose long experience as skipper of the Eolis in our dredging operations in Florida made his services invaluable. Strong and active, a jack-of-all-trades, a fine seaman, and 
expert in handling the dory while dredging or threading the passages of the reef, Greenlaw was indispensable.

The various members of the expedition assembled in Havana between May $2 \mathrm{~d}$ and 5 th, and several somewhat trying days were spent in extricating our equipage from the labyrinthine mazes of the Cuban customs. When this was at last accomplished, the schooner deck presented a disheartening aspect. We gazed with dismay upon towering ranges of boxes, barrels, bundles, drums of gasolene, trunks, suit cases, bedding, and the constantly arriving crates of provisions. It seemed an impossible task to stow away this appalling amount of equipage, and we detected the covert smiles of our crew, whose modest needs for a six weeks' cruise could safely be packed in any one of our hundred boxes. To add to the confusion, reporters arrived together with many friends of the crew and numerous visitors with cameras. We did not know just who were or were not going with us from the multitude that swarmed the deck. The cook worried about the installation of his stove and the disposition of his pots and pans. The more immediate essentials among the 
provisions were buried beyond discovery beneath bedding and paraphernalia of all sorts. Everyone searched for his own particular trunk and suit case and then for a place to stow them. Two dogs belonging to the crew barked incessantly at passing craft and dashed frantically fore and aft in the discharge of their noisy sentinel duties. A white bantam rooster, that had fallen into a pot of green paint, scrambled over the peaks of dunnage seeking a haven of safety while marking at every step our belongings with a green fleur-de-lis. Boatmen with their little craft for hire ranged alongside, not caring to leave so novel and amusing a sight. Our native crew talked excitedly among themselves using many gestures that to our unaccustomed observation seemed very threatening. To extricate ourselves from this chaos required two full days' labor.

The Tomas Barrera is the prize member of a large fleet of fishing schooners of approximately similar design and interior arrangement. She belongs to a class of boats known in Cuba as viveros, which means that she is constructed with a large tank or well occupying the middle portion of the vessel and intended for keeping alive fish 
taken for delivery in Havana. This well freely admits sea water through holes bored in the schooner's sides and is open to the deck above through a hatch covered by a removable grating. This vivero proved of greatest use to us. Below, aft, is an ample cabin with open passageway forward (on either side of the well) to a forecastle under the forward deck. Save for the low trunk over the after cabin the entire flush deck is free of interruption. A wide bulwark of about eighteen inches height surrounds the vessel. Under the long bowsprit is stretched a net, attainable by a little acrobatic effort along the stays, which furnished, to one or two at a time, an admirable retreat for quiet siestas. The cooking arrangements consisted of a series of charcoal braziers enclosed in a supposedly fireproof casing, braced alongside the cabin trunk on the port side, the adjoining portion of the cabin roof serving for a kitchen table. Sleeping below is not favored in the tropics so we provided cots which during the day were stowed away forward under a tarpaulin. At night these cots were ranged on deck in rows. In the cabin below were kept all the personal effects of the party, also an improvised writing- 
desk where all records, logs, etc., were kept. Unhappily a large amount of provisions of the less bulky order was also stowed in the cabin, along with the hundred and one articles of all descriptions which could find no other suitable place. The confusion in the cabin was generally worse confounded by the clothes, shoes, hats, and other personal belongings of the men. A carpenter had constructed a large folding table for meals and to serve also for a work bench. At night or when under way this was folded and stowed forward out of sight.

The Tomas Barrera is 65 feet on the water line, 20 feet beam, and draws between 9 and Io feet, the wide beam giving her the appearance of a larger vessel than the dimensions would indicate. She is far more strongly constructed than American vessels of similar design, "stiff" and able and carries a press of canvas which seemed to us too great for her depth. There is no auxiliary engine. Besides our own Gurnet launch, already referred to, we had been most generously offered the use of a small auxiliary sloop-rigged vivero, the Tarpon. She is a high-powered little craft and served us well as a tug and for many side excursions into shallower waters. We also carried a tender. 
Our crew was made up entirely of Majorcan Islanders and better men and sailors it would be difficult to find. They were all good seamen, cleanly in habit, sober, and efficient. Their one desire seemed to be to serve us in every way and to help make our expedition a success. Too much praise cannot be given them. Our skipper, or the "Patron," as skippers are called in Cuba, is a man of exceptionally strong and pleasing personality and his authority in all matters of navigation was absolute. His perfect control of himself and of his men, his good humor, his fine judgment and common sense, made him greatly respected by all on board.

The following is a full list of the party:
Patron
Gaspar Pellicer
Mate
Pedro Juan Matas
Cook
Bartolo Palmer
Crew
José Riera
Bartolome Jofre
Guillermo Pujol
Engineer of Auxiliary Luis Palormino
Sailor
Pablo Lesmes
Naturalists
Dr. Carlos de la Torre
Dr. Paul Bartsch 
Naturalists

George H. Clapp

Charles T. Simpson

Victor J. Rodriguez

John B. Henderson

Preparator

George W. Gill

Fisheries Expert

Manuel Lesmes

Director of Dredging Sidney W. Greenlaw

The night of May 8th the Barrera finally departed from Havana with orders to proceed to La Esperanza, the port of Viñales, and there await the arrival of the party. Esperanza is the one accessible port to be reached overland within the Colorados Reefs and is, moreover, situated at about the beginning of the region we wished to explore. By sending the schooner ahead we could avoid the open sea run from Havana and at the same time avail ourselves of a day or two in the field about Viñales. Greenlaw and Gill remained aboard. 


\section{CHAPTER I}

\section{Overland to La Esperanza}

7 HE line of the Western Railway of Cuba follows the level central portion of the island and passes through the famous Vuelta Abajo. Just before entering the Pinar del Rio province the eastern projections of the Sierra de los Organos appear. From the car windows ranges of mountains to the north are thereafter always in sight, and many of the station names along the line recall places made familiar to us by the early naturalists of Cuba,Candelaria, Artemisa, Paso Real, Rangel, San Diego Baños,-all having a type-locality sound. The mountains as seen from the cars, however, do not present the characteristic sierra aspect.

The soil of the plain traversed by the railroad, called the "lower valley" (Vuelta Abajo) is of deep brick-red color derived from the iron salts leached out of ore beds that exist in greater or less extent throughout the hills of Western Cuba. It is 


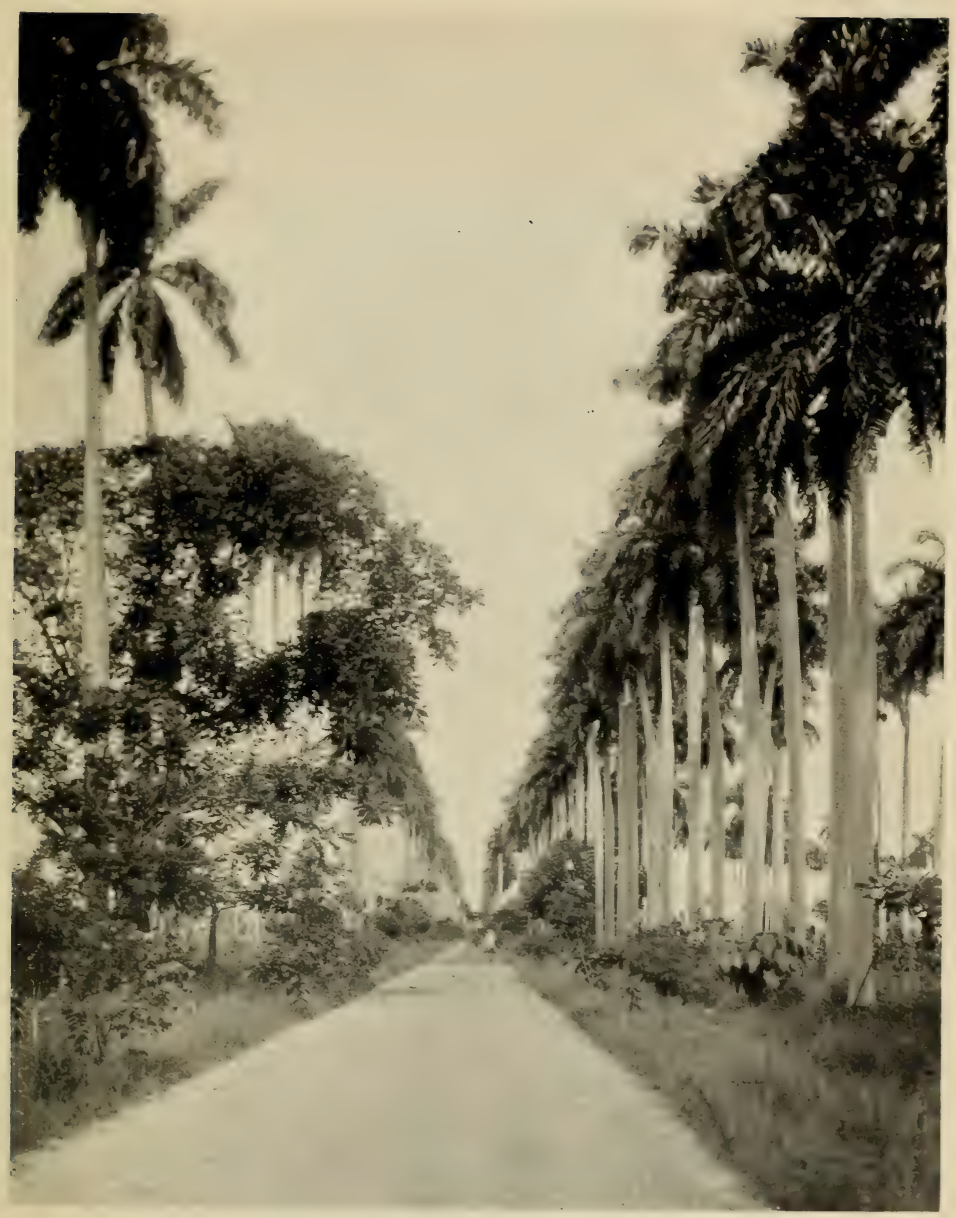

ROYAL PALMS ALONG A ROADWAY

Reproduced by permission of the American Photo Co., Havana, Cuba 

exceedingly rich and contains the peculiar qualities necessary for growth of the finest grades of aromatic tobaccos. Tobacco fincas (farms) are everywhere seen with growing crops covered by great tents of cheesecloth. At Herradura are met the large fruit farms of an American colony. The even rows of well-kept trees are agreeably suggestive of home orchards. It is only when the American houses of the town come into view that an unpleasant impression is gained. Pine board habitations, without a redeeming architectural feature, contrast unfavorably with the native Cuban houses, which, however primitive, have a certain charm for foreign eyes and seem better adapted to the needs of the climate.

The royal palms (Roystonea regia) are to $\mathrm{Cuba}$ what elms are to New England, poplars to Normandy, and her great towering pines to Norway, only, as Artemus Ward would add, they are more so. One can hardly conceive of a Cuban landscape without them. They are the botanic glory of the island. Although introduced into other countries where climate and soil are suitable, yet they never appear quite so well as in their native soil. Here, in attaining their full development, they represent 
the very acme of arboreal grace. In the Havana province, where a rich limestone soil is the rule, they reach their greatest splendor of even smooth straight stem and rich color of leaf. They are perhaps slightly less perfect in Pinar del Rio where their presence always indicates the best patches of soil. The beauty of these trees along the railway line is often marred, however, by the cutting of the great leaves for use in thatching the native houses or bohios, and the alternate thinning and swelling of the trunks indicate the successive despoilment of their foliage.

Proceeding west, a gradual change in vegetation becomes apparent. A straight stemmed cabbage palm (Inodes umbraculifera), tall growing and of stiff formal appearance, appears more and more frequently, the royals gradually disappearing. It suggests at once its near relative, the Floridan palm, Inodes palmata. Besides this cabbage palm, one or more copernicious palms of low growth and large fan-shaped leaves appear, and in places almost dominate the landscape. Then comes the Acrocomia lasiospatha, a palm of swollen fusiform stem, thickly covered with spines, first appearing singly and then scattered about in groups. 


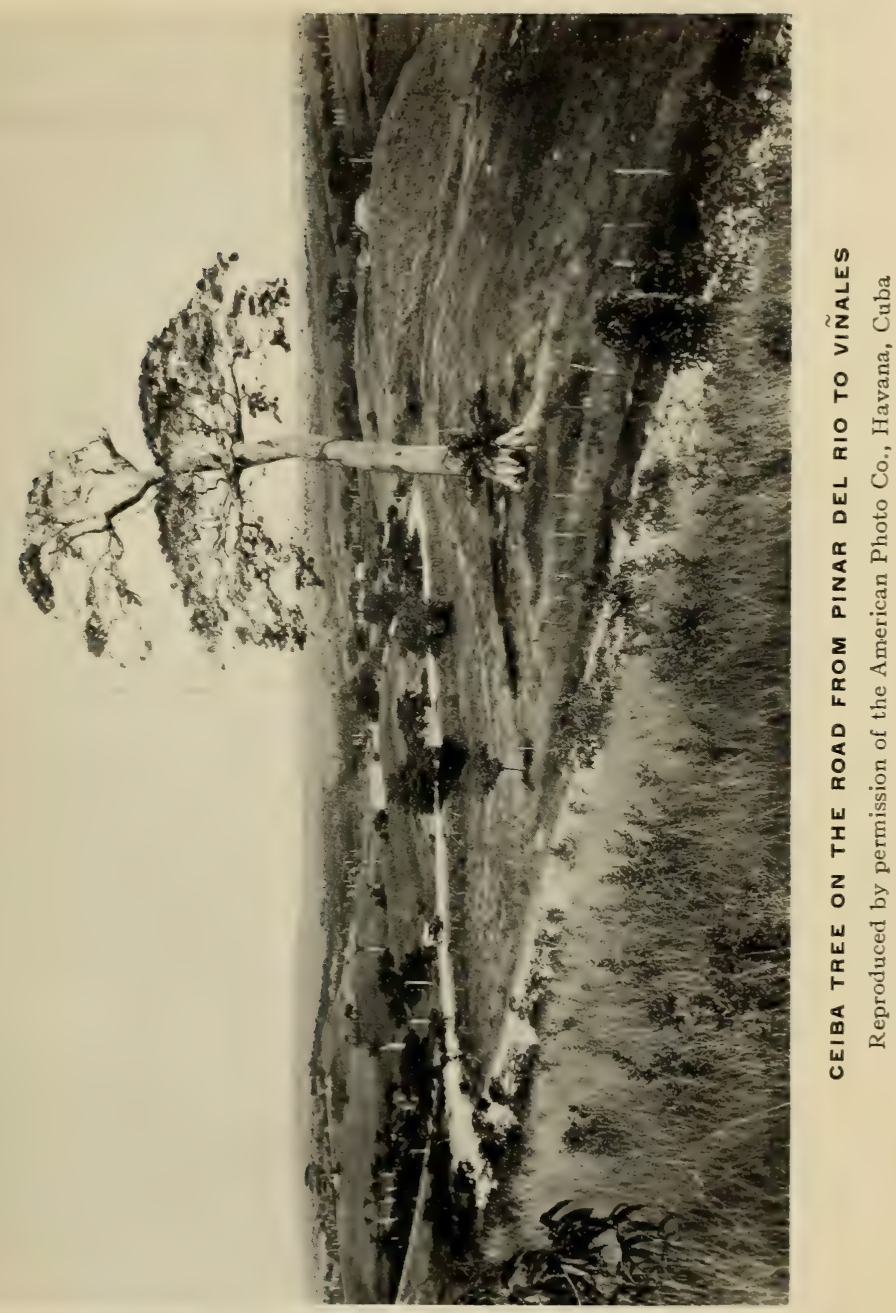



As the train approaches the city of Pinar, a more abrupt change in the vegetation occurs. Occasional pine trees appear, and the palms, already noted, give place to the extraordinary "bottle palms" which are confined to the narrow geographic range of the western central portion of the Vuelta Abajo. These palms (Colpothrinax wrightii) carry to laughable exaggeration a swelling in the trunk which to a far less degree is characteristic of many other species. This bulbous swelling, however, is absurdly out of proportion to the otherwise spindling stem, and the tuft of leaves at the top is straggling and insufficient, making the tree seem very grotesque. Simpson's tender reverence for all palms often involved him, as their champion, in heated arguments for their defense, against the claims for beauty or usefulness we urged for other types of trees, yet even he declared that the sight of these bottle palms was enough to excite the risibles of a sphinx. This species flourishes only in a soil too poor for royals.

No very important use for the soft porous wood of palm trees has yet been found, and their dead trunks are left to decay. We speculated as to their 
possible use for wood pulp, and entertained the disquieting thought of an invasion of pulp mills.

About all the stations along the line, the railway company has shown good taste in planting many flowering shrubs, mostly of foreign origin. Among these one is struck by the blossoms of the Chinese Hibiscus (Hibiscus rosa-sinensis) which present large splashes of brilliant color. To northern eyes the greatest charm of these miniature botanic gardens is in the wonderful Bougainvillea vines that smother the fences and lattices and sometimes the station houses themselves, hiding them beneath a mantle of deep royal purple. The rich color of this creeper is derived from the two or three last leaves upon each stem and not from the flower itself which is an inconspicuous little yellow affair scarcely noticeable amid the riot of purple splendor. Some varieties of this wonderful creeper seen at the railway stations are of a reddish tint equally startling. Among the trees in the station enclosures one's attention is immediately drawn to the Sacred Ti or Bo trees (the Ficus religiosa of India). These trees with perfectly round smooth trunk and ball of dense olive-green foliage have a decidedly artificial appearance as though intended 


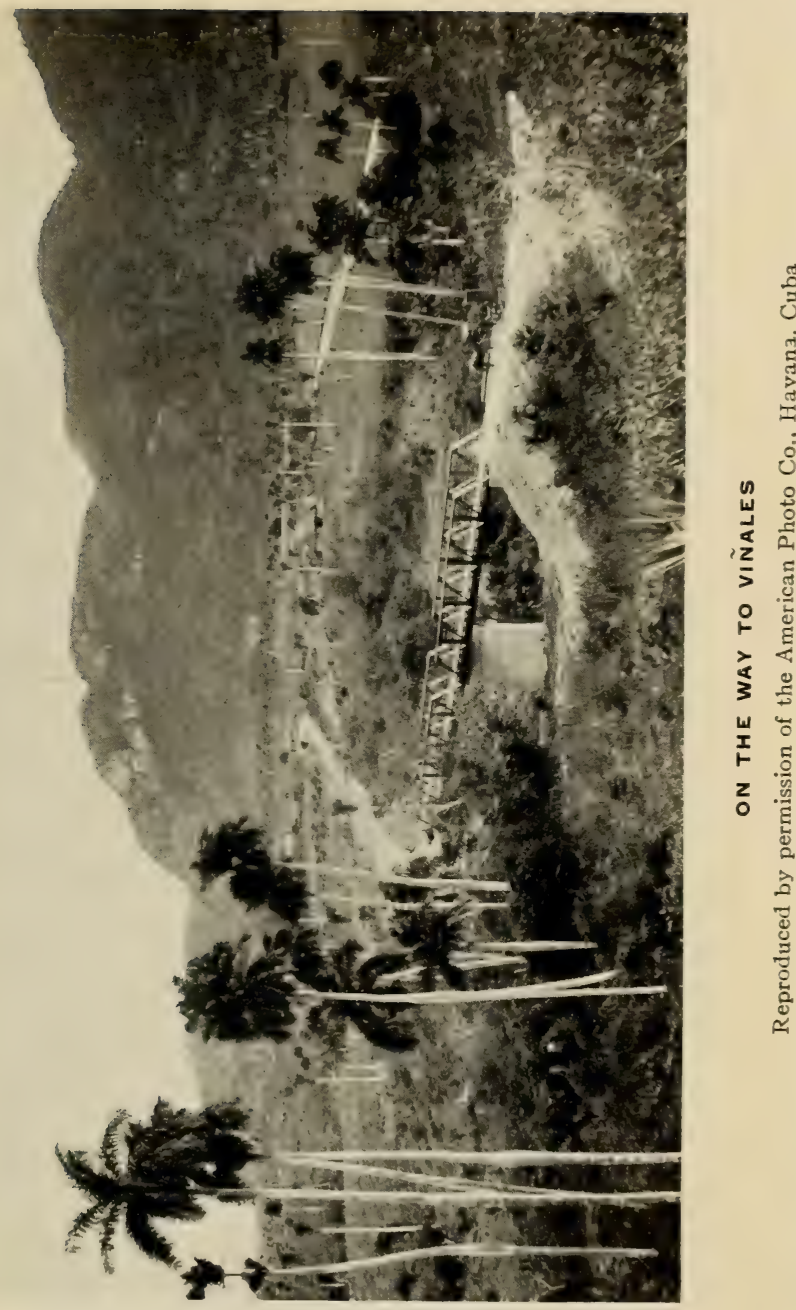



for huge tubs to line the garden walk of some Brobdingnag's palace.

At Pinar we selected two cabs that looked as if they might possibly hold together as far as the Ricardo Hotel. The old Ricardo is the human clearing house of Western Cuba. It is the starting point for all travelers bound to the tobacco regions in the sierras. For us it was our last outpost of civilization.

The next morning (May 9th) we started early by automobile for Viñales. Those of us who had made this journey before in a ramshackle trap, bumping along the execrable road over the mountains, could scarcely realize the change. The former journey of a day's length can now be made in an hour by motor over a fine macadam road. It is to be hoped that the Cuban Government will keep up the good roads policy inaugurated by the Americans during the first intervention. The sierra country of western Cuba, with its perfect climate, is one of surpassing loveliness, and given easier approaches and good roads it should become a favorite winter resort and playground for the Americans who go south. There is nothing quite like it in the United States. 
With clanging of bells, shriek of Klaxon, scattering of children and domestic animals, our chauffeur fairly shot out of Pinar, taking the Vinales road with a rush that made us beg for mercy. Arrived at "Kilometer I4" we stopped to explore a mogote, the isolated remnant of a limestone sierra, which, with two or three smaller mogotes near by are the last surviving portions of a vanished range of mountains.

As we shall have more to say of mogotes and their importance to us in our work, it would be well to explain here just what they are, and why we were always eager to visit them. The Spanish language is rich in nomenclature of all that pertains to topographical features. The word mogote (only used in western Cuba) indicates a limestone elevation more or less isolated from a main range of mountains and standing alone or at least semidetached. The word loma is applied to a hill of rounded smooth outline which is generally composed of slate or sandstone shales along with the clays and sandy soil resulting from the disintegration of those classes of rocks. The different origins of these two types of elevations give to each a very characteristic appearance. The mogote is 
weathered into a more or less precipitous elevation of white limestone and festooned with the rank vegetation a rich soil produces. The lomas are less steep and often quite barren of trees, their clays and sands affording but scant vegetation. Usually, however, they are lightly covered by an open forest of scattered pines and a wiry long grass. In their valleys and arroyos where moisture is more permanent, a growth of tree ferns is often met, bu' they always lack the rich lush vegetation of the mogotes, above which the plumes of tall palms are a distinct element.

All the northern half of the Pinar del Rio province is a mountain maze of high rounded lomas, a former elevated plain of some fifteen hundred feet now eroded into great land surges without particular alignment or system. Directly up through the central portion of this mountainous area are projected a series of more or less parallel limestone ranges. These great ridges have east and west axes and attain a greater elevation than the lomas. They are known as "sierras," and though distinguished by many individual and local names are called in general the "Sierra de los Organos" or "Organ-Pipe" Mountains. The 
appellation is not inept, for, like limestone mountains the world over, they have been carved by atmospheric agency into all manner of fantastic shapes and often present from a distance this organ-pipe appearance. They are always very steep, often displaying vertical walls (paredones) of quite one thousand feet elevation. They are densely overgrown, wherever vegetation can find lodgment, with a very characteristic flora, and harbor a rich and varied fauna both altogether different from that of the lomas or of the lower plains. It is upon the sierras, that Cuba's astonishing wealth of molluscan life exists. As these land mollusks cannot maintain themselves away from the limestone of the sierras, their restricted little world may be said to consist of the "continental area" of the sierras and the "islands" represented by the mogotes. From whatever source was derived this extraordinary aggregation of land shells with its many unique species and genera, it is reasonably certain that it developed to its climax only since the elevation of these sierras. Since this elevation, the forces of demolition have been actively at work, and their original range of habitat has continually dwindled in area. Their "conti- 


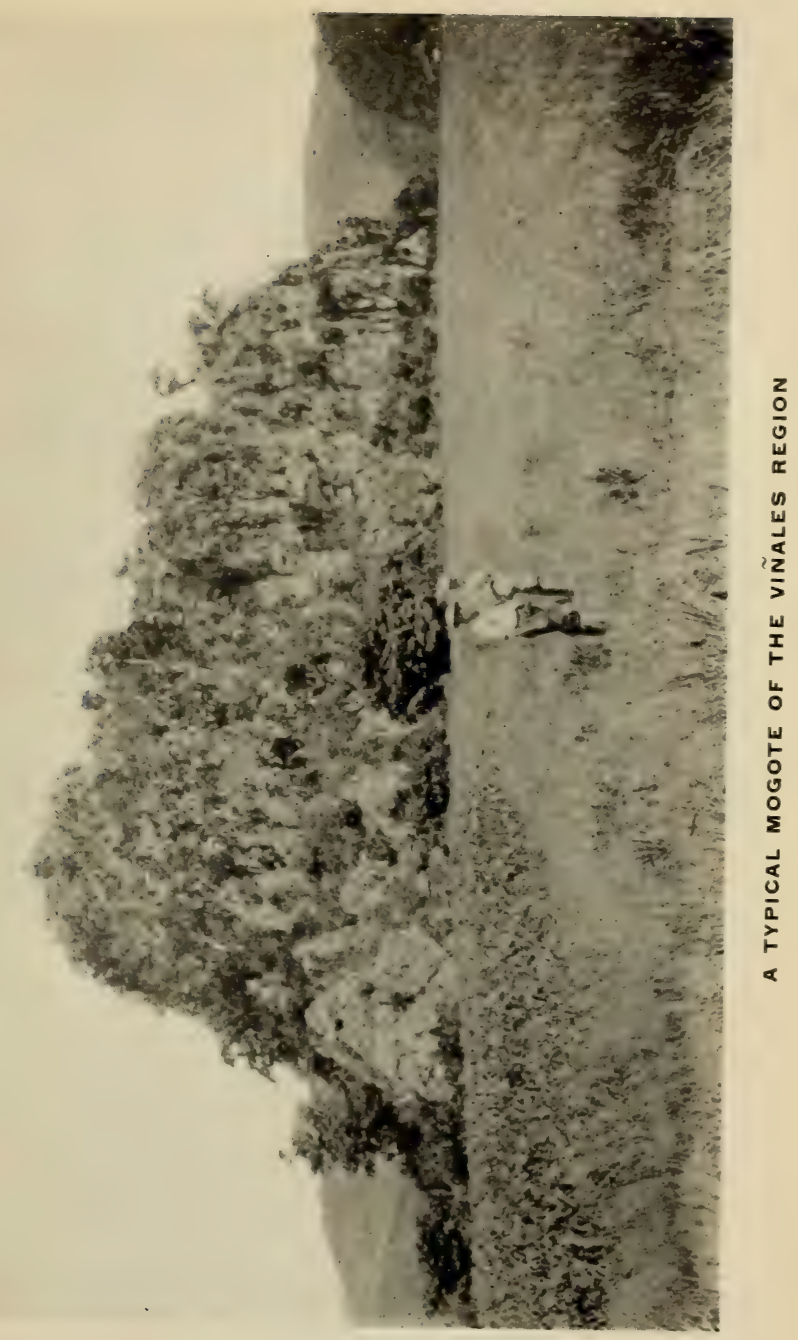



nent" has been broken into several long series of interrupted sierras and the innumerable "islands" mogotes. The constant mutations slowly going on in all living species are most strikingly shown by a comparative study of the life, especially of the mollusks, that have suffered isolation upon the lesser sierras and the mogotes; indeed the answer to most of the puzzles concerning the origin and the development of the Cuban fauna must be sought in the modified faunas of the mogotes. This line of investigation, with abundant material offered for study, becomes a most absorbing one.

In every faunal area of the world there are certain genera that appear to be more "plastic" or quick to adapt themselves to changing conditions of life. Among land snails the Cerions of the Bahamas and coastal Cuba, the Clausilias of Europe and Asia, and the Urocoptids of the Antilles may be cited as good examples. Many more could be given of quite the opposite characteristics among genera and species which have suffered extermination through comparatively slight changes of environment. Hence for material for evolutionary study we were always hunting for mogotes in Cuba and on the mogotes our special 
object of search was the Urocoptids, the "plastic" upland genus of the island.

We fell upon the mogote at Kilometer I4 with great enthusiasm, first, because it is so far away from the nearest line of sierras and is apparently in the axis of a former range now eroded away, and, second, because it was our first collecting station and we had the ardor of great expectations.

At the time of this our first visit here, the rainy season had not yet set in, and as a consequence of dry conditions, the collecting was not so good as we hoped to find it. The land mollusks of Cuba have but one period of activity which is during the wet season beginning in May and June, and lasting until October. During the balance of the year they remain for the most part in a state of æstivation, an occasional rain during the dry months not being sufficient to awaken them to activity. During the winter months, however, many of the operculates remain attached to the rocks and can easily be found. The Helices with few exceptions hide away beyond easy discovery, though many of them select less hidden places for the long sleep. Dead specimens can always be seen in proper localities and these furnish an index to the fauna. 
We were pleased at Kilometer I4 to take a Chondropoma and a Urocoptis quite new to science. A little blind snake, the Typhlops lumbricalis, fell to our collecting. This primitive degenerate little creature lives entirely underground burrowing about much like an angle worm and feeding upon grubs and insects. Having no further use for vision the skin of the head grows over the eyes which may be detected by a careful inspection as tiny little spots. The diminutive snake seemed very ill at ease when exposed to the open air and sought to bury his head between one's fingers and to work downward and out of sight. They are quite common in the soil of the fields and can usually be found by following a plowman.

Having traversed several miles of dreary pineclad elevations the macadam road surmounts the last loma and begins a steepish descent into the valley of Viñales. Photographs give but a poor idea of the sublimity of the scene that confronts the delighted traveler who views for the first time this exquisite valley. Ranges of sierras on the north rise abruptly from its level floor, while other and still higher ones, forest-covered and brilliant in green and white, tower beyond. Through gaps 
in the ranges, narrow passes open into cul-de-sacs almost wholly "land locked" by perpendicular walls; and scattered over the level floorlike surface of the valley are verdure-clad mogotes resembling giant ruined castles and ancient battlements. The great bulk of the sierras dissolves from view on the east and west horizons where individual higher peaks, purplish and indistinct, loom up above the hazy mass. Down in the valley trails like red ribbons wind past groves of royal palms, cultivated patches of vivid green, and the many palm-thatched bohios of the natives. Off to the right at the foot of a huge mogote, El Tumbadero, lies the little village of Viñales, its tiled roofs glistening amid the foliage of its trees. A small yellow cathedral with bell tower, like some ancient church in Andalusia, occupies a central square and guards the faith of the inhabitants. Large birds float lazily two thousand feet above. We quieted the motor that we might enjoy undisturbed this rare scene of beauty.

The valley of Viñales must not be compared with the Yosemite or the Grand Canyon, nor with some famed Alpine passes, for it cannot display the astounding contrasts of these or many well- 


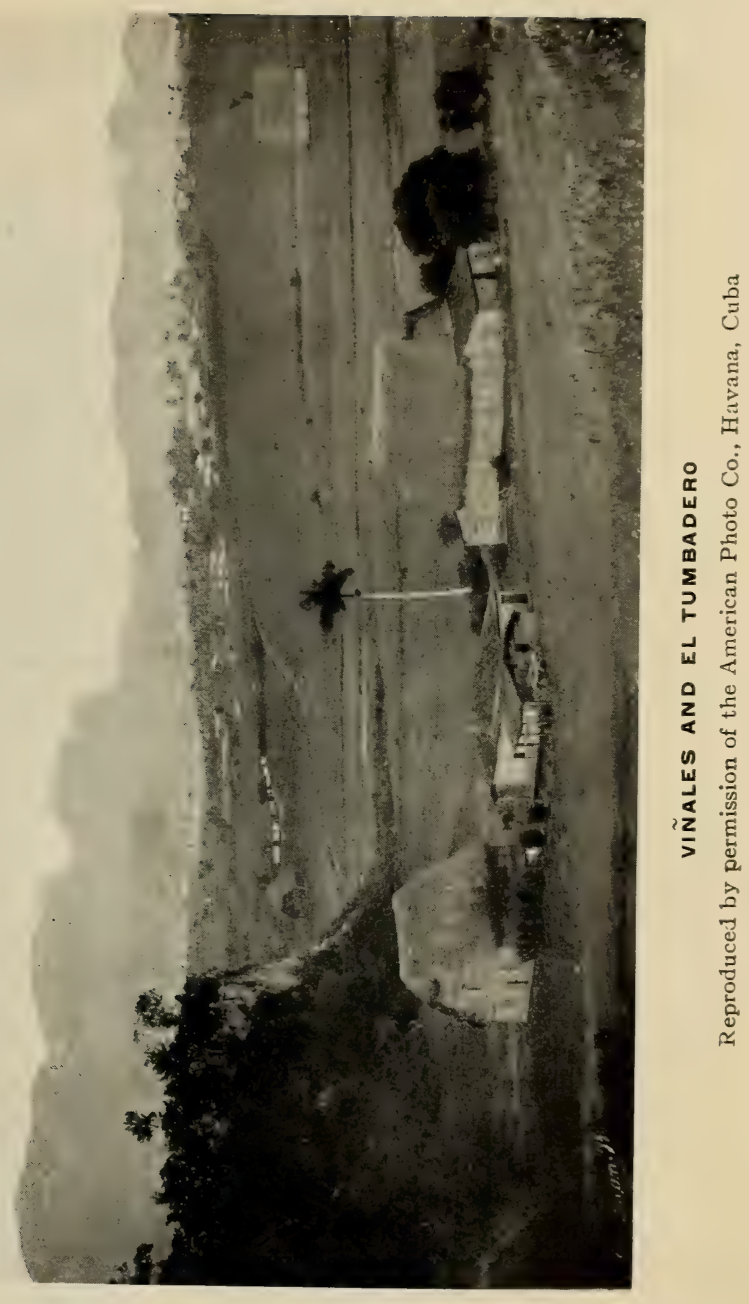



known valleys among the higher mountains of the world. We were all of us traveled men who viewed this panorama, but all agreed that never before had we gazed upon so charming a sight. There are recesses among the Rocky Mountains of Canada into which one gazes with awe and abated breath, where the very silence oppresses, and the beholder instinctively reaches for support to guard against slipping into the awful chasm below. But on the contrary, the Valley of Viñales seems to soothe and lull the senses. Like the great birds suspended in the sky we longed to soar above it and then alighting within some palm grove far below to rejoice in its atmosphere of perfect peace.

A swift descent brought us into the little village of pink and blue houses fronted with rows of columns, and to the inn where our host, of good memory, greeted us with a cordiality that made us feel like wanderers returned home.

The little inn at Viñales is so very old Spanish that we liked to fancy Don Quixote and the faithful Sancho Panza entering at any moment through its big open door. Mounted upon Rosinante and the donkey had they passed quite through the dining-room to the courtyard beyond, we should 
have had the only touch necessary to defraud the calendar of some five hundred years and to transport us to medieval La Mancha. What the inn may lack in luxurious beds and modern conveniences is amply compensated for by a quality of charm that made us content the moment we entered. In the early evening the young people of the town gathered in the square opposite to parade up and down, girls together and men together, native fashion, for inspection and admiration of one another. The girls' black eyes flashed sidelong glances against the bolder gaze of the rustic young men. The church bell in the open tower above pealed forth a clanging discord to give notice of service to be held within. In the street an itinerant orchestra executed music of a primitive kind. All native Cuban music is set to a "time" that we AngloSaxons cannot understand nor easily imitate. It combines an element of negro syncopation with much monotonous repetition of one note, so characteristic of Moorish music, but it is thoroughly Spanish in scheme of harmony. The usual broken accompaniment is more or less strictly followed; the theme is always suggestive of some Spanish song heard long ago, but vaguely recalled. 


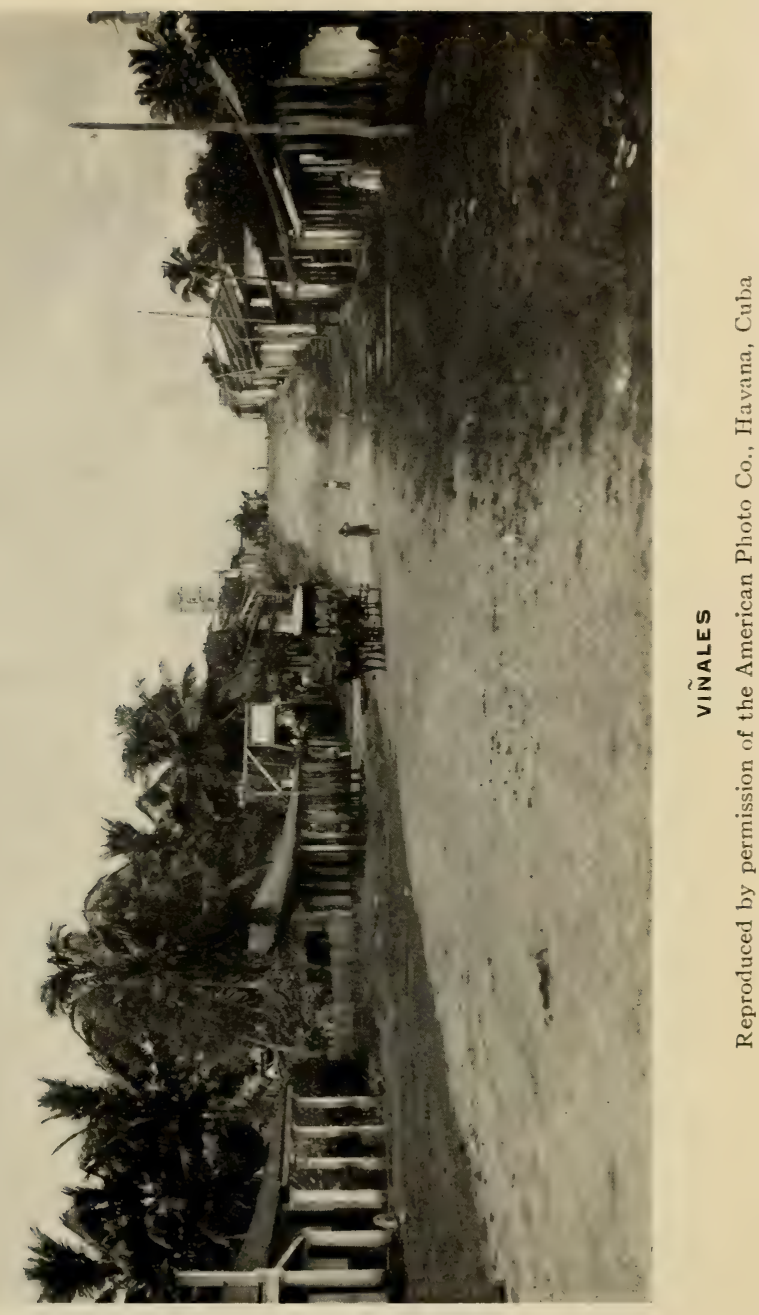



The drums, a prominent feature, beat a tattoo that suggests the barbaric interrupted rhythm of the tom-toms in Haiti. When all appears to be going well and strong, the music abruptly stops, only to begin again by repeating one note in greatly accelerated time. Then it stops for good as you begin to shuffle your feet in hopeless attempt to mark the curious time. The final note is usually not the tonic of the key, hence you are left dissatisfied and wish the orchestra would either finish the composition or move away altogether. The curious effect in the rhythm is produced by employment of two tempos-the $3 / 4$ and $2 / 4$-at one and the same time, or, frequently the mingling of thirds and seconds in a manner that (on the piano) one hand plays three notes while the other strikes but two. This sort of music is heard over all rural Cuba, but in Havana only at the cheaper places of amusement. Elsewhere in Havana the music is the same as in the United States, and the frolicsome American "rag time" has apparently captured the Habaneros as it has all Europe.

To the naturalist in search of specimens for his laboratory or cabinet, Viñales is a paradise indeed. 
At this particular point the Sierra de los Organos may be said to be at its very best. Several more or less distinct ranges come close together and offer the great advantage of convenient passes from one to the other. The collector of landshells, or insects, or reptiles, or birds, - the botanist with his herbarium, the geologist with his hammer seeking to unravel the mystery of the mountains, - must stand at first a little confused, not knowing just which way to start, the outlook being so inviting in every direction. These calcareous mountains are areas of great concentration of life, and they are therefore very generous to him in search of specimens. They are full of wonderful caves, deep gorges, perpendicular walls, overhanging cliffs, rivers that appear from underground and disappear again quite as mysteriously.

No one uninoculated with the virus of nature study can quite understand the feelings of a naturalist who first stands upon the threshold of his promised land. The hunter has his thrill at sight of game and he derives a savage and elemental sort of satisfaction when he destroys its life. The fisherman loves the feel of a strike and he too lives faster as he watches his victim gasp out its 
life at his feet. But neither of these knows the intense and more intellectual pleasure of the naturalist, he with problems to solve, and secrets of nature to probe. When arrived at last where the book of nature lies open before him, its language acquired and its characters understood, he feels a real exaltation. Our naturalist has most likely studied in laboratories and museums among depressing specimens of preserved life. $\mathrm{He}$ has measured bones of dead creatures, dissected their hardened and distorted tissues, but dreaming always of some happy day when he may see them alive amid their own surroundings.

We could scarcely curb our impatience to secure the only cab of Viñales-a vehicle even more pitiful than the Pinar cabs-and drive to $\mathrm{La}$ Puerta del Ancon, a narrow pass through the Sierra de Viñales and by which the road enters another beautiful valley beyond. At this place we knew there were some fine land-shells to be found; and just "around the corner," on the north side of the Sierra de Viñales, a cove of surpassing beauty, is the special haunt of one big lusty land-shell that we much wanted (Cepolis subtussulcata). We fell upon the spot and in three or four hours had 
secured a notable catch of remarkably fine landshells, many insects, moths, and butterflies. We observed on the vertical walls at the Puerta del Ancon a most interesting plant of the genus Anthurium with large cordate glossy leaves and now exhibiting spaths of dull purplish flowers. This curious plant, with even more curious relationships and which we never observed elsewhere, is related to our calla-lily and belongs to an order abundantly developed in the American tropics; another near relative is our Indian turnip.

In the cove on the north side of the Sierra which we christened the "Cove of Delight" we met with a truly remarkable development of many species of ferns, conspicuous among which are Adiantum or "Maiden Hair," Hymenophyllum of delicate lace-like texture, Davallia with wonderfully cut leaves, and Trichomanes with triangular fronds. From the trunks of most of the trees hang long grass-like tufts of various species of Vittaria.

When we returned to the inn flushed with excitement, we chattered about our experience like so many schoolboys after a ball game.

At the Puerta del Ancon, an excellent example is furnished of the manner in which the cave forma- 


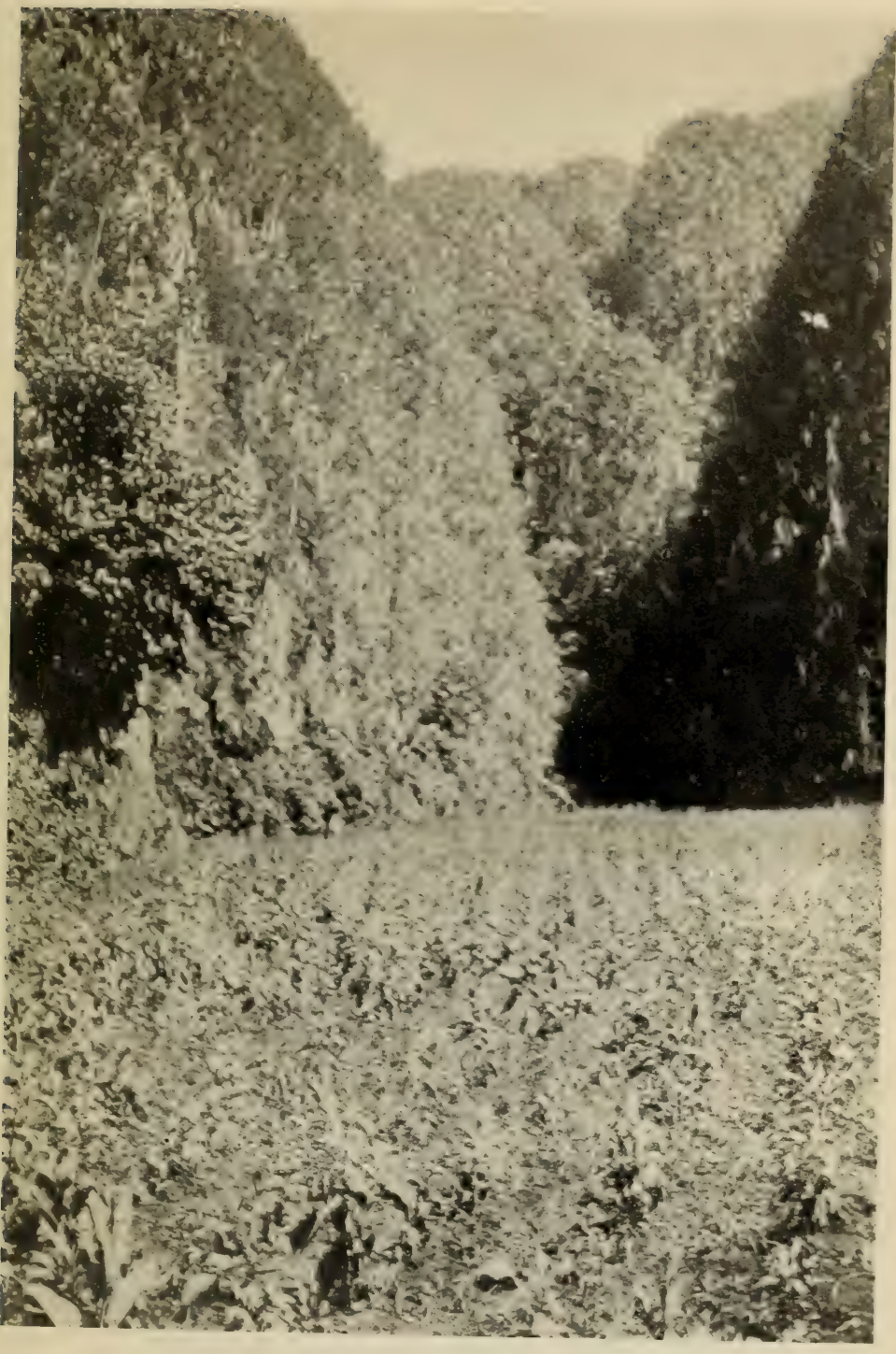

COVE OF DELIGHT

Tobacco in the foreground 

tions, always going on within the sierras, break down the mountains, ultimately entirely destroying them. The walls on both sides of this pass are concave and exhibit remnants of huge stalactites. It is obvious that at one time the sierra at this point was unbroken and continuous, but that a cave formed gradually enlarging, until the weight of the roof carried it down in a great crash. Some of the remnants of this roof still exist in the form of great boulders lying within the pass through which the macadam road is built. This cave formation explains many of the curious topographical features of Cuba and Jamaica-the round deep valleys (hoyos) of the former, and the "cockpits" of the latter.

Cuba is the richest island in the world for land mollusks. It possesses more genera and species of greater diversity and loveliness of form and color than can be found in any other island, or equal continental area in the world. The total is composed of three faunulas, or elements,- - corresponding with the three mountain systems of the island. While this can be recognized as "Cuban" in the broader sense, it is nevertheless quite true that these three subfaunas differ so markedly there is 
ground for belief that they possess different origins and have developed independently. One of these subfaunas is of the Sierra de los Organos, another of the mountain systems of central $\mathrm{Cuba}$, and the last is of the highlands of Oriente or Santiago province. These three subfaunal areas are equally marked by the distribution of other Cuban animal forms, such as the insects and reptiles, but probably by them not so sharply differentiated, for in course of time both insects and reptiles could have migrated more easily than the slow-moving snails, and could more quickly traverse intervening regions not suited for a permanent home. Besides these well-marked subfaunal areas there are three others less distinctly recognizable owing to their more composite elements. These are the much eroded limestone mountains of the Havana and Matanzas provinces, the Cubitas range of northern Camaguey, and the low-lying coastal strip of recently elevated coral reefs which almost encircles the island.

From whatever source came the Cuban land snails, whether from some remote land connection with Yucatan or Honduras, or whether, like Topsy, they "just growed" from native origin, it is 
reasonably certain that the three subfaunal provinces once constituted three separate islands. Such was the condition at the close of the Jurassic period and continued through the Tertiary epoch. At the close of the Tertiary, the mere yesterday of geologic time, the Havana province was raised from a shallow sea and its hilltops appeared as an archipelago of small islands. These derived their fauna from both the large islands then existingthe Organ Mountains to the west and the Trinidad Mountains to the east. The last chapter in Cuban geological history has been the successive elevations of coral reefs built upon her narrow island shelf. Here we find a suitable home for land-shells in a limestone rock and soil but with life and food conditions different from that of the high sierras. The species that have migrated there from other and older regions and have survived the changes of environment have become modified into a group of almost subfaunal importance.

The remarkable land-shells of Cuba have been made known to science chiefly through the efforts of four distinguished naturalists, who combined with their interest in mollusks an equally great interest in other forms of Cuban life. The first 
of these was a German named Gundlach. He came to Cuba with Louis Pfeiffer in I830 and died but a few years ago. Contemplating only a short visit to the island, so fascinated did he become with its charms he never again left its shores save for short periods. His entire life was devoted to the study of Cuban natural history, and because of a zealot's contempt for the material things of life he accepted willingly the sufferings of poverty as a price for freedom to study. In his old age he sold his valuable collections to the Cuban Government in order to raise money to rescue from want a family that had formerly befriended him, they having lost their fortune in the civil wars. I once asked Torre, who knew him, what manner of man was Gundlach and he replied: "He was a saint."

Charles Wright, an American collector of plants for Asa Gray and Ghiesbach, spent four years in Cuba during the latter fifties and early sixties. With a long patriarchal beard, taciturn and unsocial, he was a man of great physical strength and endurance. At that time the Cuban mountains were overrun with brigands and outlaws of every description and to travel among them required nerve. Wright, without speaking a word of 
Spanish, traversed the length of the island afoot leading a little donkey upon which he packed his precious collections. For weeks at a time he slept in caves, ate wild honey, and lived like the aborigines. Once, when searching for rare water plants in the great swamp jungle of south Cuba (Cienega de Zapata), he was observed, by some startled natives, swimming in the crocodile-infested black waters of the swamp, his long beard floating back while he blew the water from his mouth like a grampus. The natives thought him to be some unheard-of animal and beat a hasty retreat while there was yet time. Wright was a wonderful collector and some of the finest Cuban species discovered by him have never since been found, notwithstanding the fact that he carefully recorded localities in a journal and in correspondence still preserved.

Felipe Poey was the third of the Cuban naturalists to make known the land shells of the island. He was not himself a collector like Gundlach and Wright, but a student and teacher. He is regarded as the father of Cuban natural history and his students from all over the island supplied him with material for his two-volume work entitled Memoria 
sobre la Historia Natural de la Isla de Cuba. The last of this "big four" was Rafael Arango who collected extensively and published a critical list of both marine and land shells of the island. Many others have contributed to our knowledge of this subject, notably the distinguished French naturalists Orbigny and Morelet, and lastly, Dr. Carlos de la Torre, whom we claim as our own, both because he has received the distinction of an honorary degree of Doctor of Science from Harvard University on account of his research work in the natural history of his native island and because he was with us on our trip. Indeed, he arrived from Havana that very evening along with Rodriguez and Lesmes.

The next day was devoted to collecting about San Vicente de los Baños, a charming spot at the foot of La Chorrera. Los Baños, as it is locally known, is on the way to Esperanza and about three miles from Viñales. Here we greatly enjoyed the hospitality of Señora Piad and her interesting family. There are some warm springs of sulphurous water at Baños, but the hotel that once sheltered many guests seeking their curative effects is now in ruins, the result of a hurricane that devastated this region some years ago. 


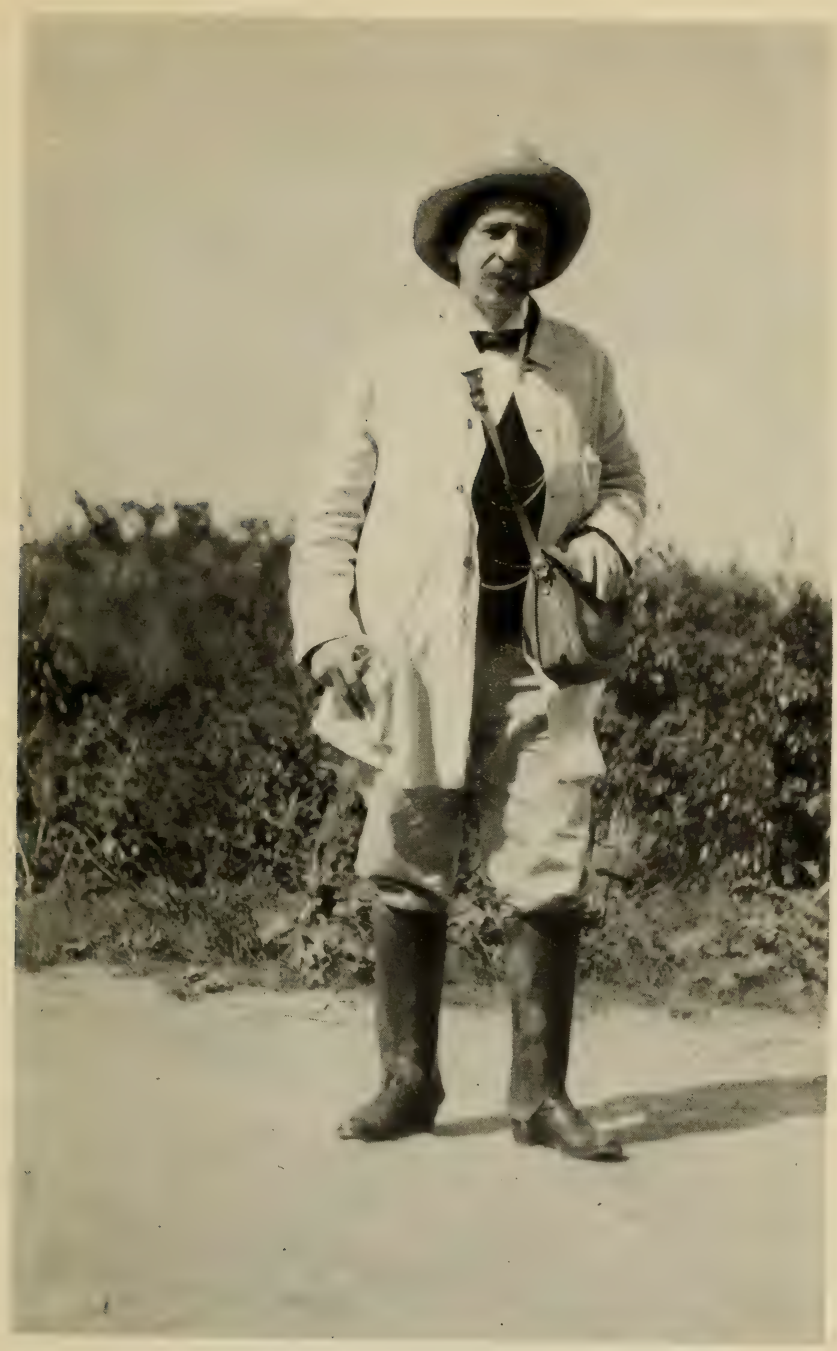

DR. CARLOS DE LA TORRE 

There can be no more perfect and spontaneous hospitality than is found everywhere in Cuba, but especially, perhaps, in the western province of Pinar del Rio. We were many times embarrassed by the refusal of our rustic hosts to accept pay for food or accommodation and often in the cases of peasant families where our entertainment must have been a burden. Unfortunately many American tourists who visit the country beyond Havana assume, perhaps unconsciously, an air of superiority over the natives. The sensitive Cubans detect this and resent it. Throughout a journey that took us into the remotest wilderness we never met with a single act of discourtesy and we were daily taught, by example, lessons in graciousness of conduct.

Late in the afternoon, after a strenuous day of collecting on La Chorrera, we took the motor diligence to Esperanza. The road passes through superb scenery, especially as it skirts for a mile or so the perpendicular walls of the Costanera de San Vicente. This sierra is a part of the northern range presenting its northern side to the sea. The motor bus lumbered along across the sandstone lomas, now bereft of their pine trees by the same 
cyclone that destroyed the hotel at the baths. The great north range of sierras seemed to rise higher and higher as we left them behind us on our route to the coast. We bid them farewell, for a time, to join the schooner that now awaited us at Esperanza. At dark we reached the uninteresting little port, scrambled upon a decrepit dock, and took the launch for the Barrera. We received a noisy ovation from Luis and Mulatica, the two dogs on board.

The Barrera was anchored about two hundred yards from the dock. A northeast breeze ruffled the water into phosphorescent whitecaps. Scudding clouds opened and closed to view intensely bright stars that shone without the twinkle they have in the north. We groped about the obscure deck for our beds and turned in, full of enthusiasm and lively anticipation for the morrow-our first day of the cruise. 


\section{CHAPTER II}

\section{La Esperanza}

Monday, May IIth. According to a very flowery Spanish writer, "the glorious star of day arising from a couch of burnished cloud" revealed to us a more hopeless confusion on board than ever. The Gurnet dory lashed on deck, looked as big as a Cunarder. The chaos above, however, was nothing as compared with conditions in the cabin below.

Before anything else could be done, a second house cleaning was in order. The bunks on one side of the cabin were again cleared for the reception of our bottles and jars, boxes, electric lanterns, and collecting receptacles of all kinds-our naturalist's lazaretto; the desk, set in the best position for light, was already overcrowded with reference books, papers, logs, writing utensils, instruments, and a multitude of small objects of doubtful use. Our trunks and bags were on end and upside down. To open any one of them necessitated doing 
violence to another's outfit. There was no place to hang anything except upon the decorative frame of a mirror and a picture of saints, so the mirror and saints were quickly concealed behind a dozen coats and sweaters, so to remain during the entire cruise. Everyone exchanged his land costume of khaki and leggings for the nautical white duck. It is a phase of human vanity to wish to appear sartorially all right at sea, especially at the start. There were none to admire our fine clothes, yet we bedecked ourselves as if to appear at a yacht club regatta. In a very few days, however, we were a sorry looking lot of halfdressed vagabonds, and had it not been for the painful effects of a vertical sun, we would likely have reduced costumes almost to the "altogether" and thereby scandalized our crew. The modesty of a Spaniard or a Cuban and his objections to nudity while in the water was to us a matter of some surprise. We always stripped for the morning plunge and our crew never recovered from shock at sight of such outrageous immodesty.

If the prospect close at hand was discouraging, the distant view was truly inspiring. None of us had ever looked upon the Sierra de los Organos 


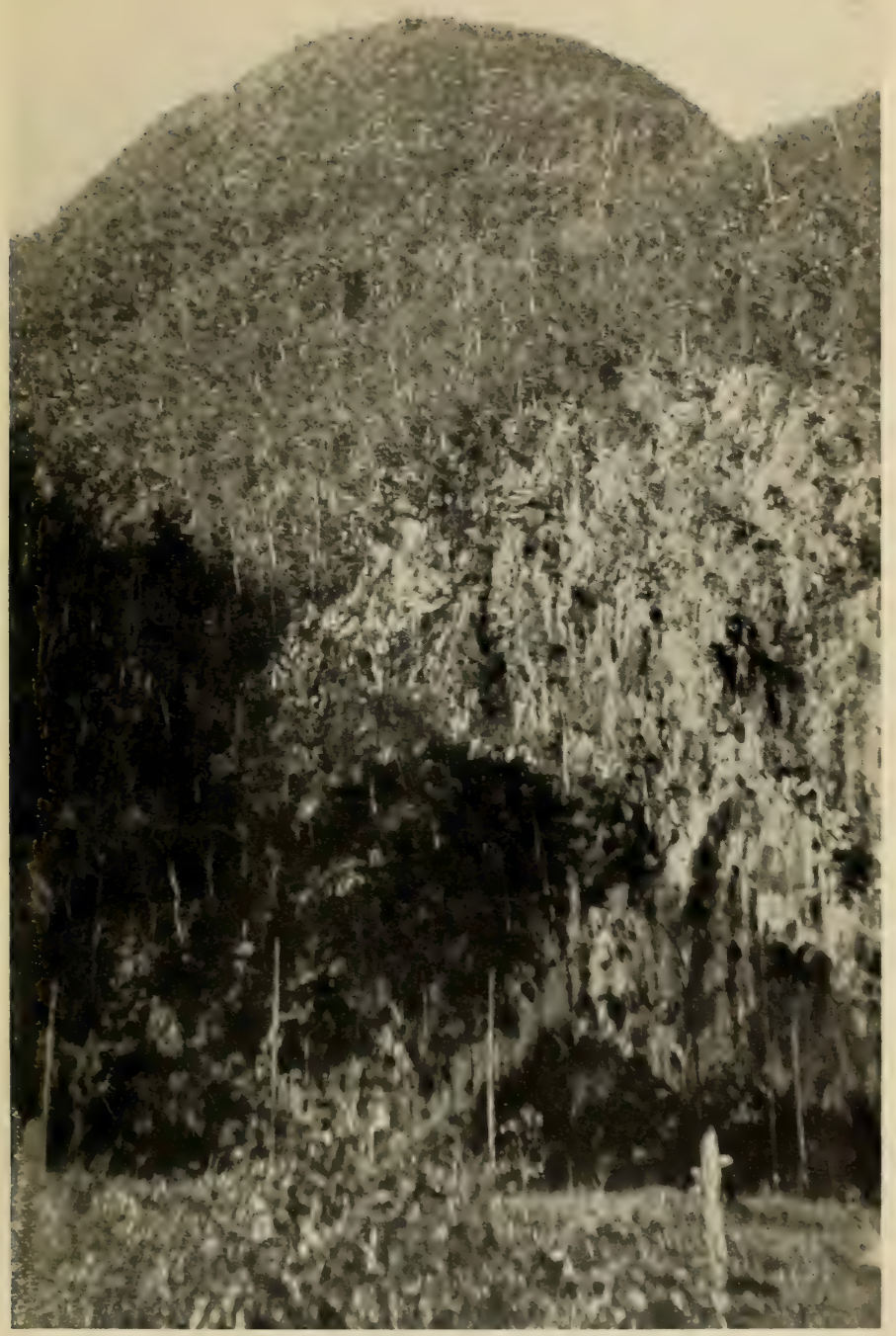

COSTANERA DEL ABRA 

from the sea, and the sight of these mountains eight or ten miles inland is superb. From Guajaibon, vague and indistinct in the east, to Azucar in the west-a stretch of seventy milesthe sierras fill the southern prospect. We could distinguish the San Andres Range, unknown to naturalists, the Mogotes de la Sagua, that final scene of Arango's exploration when as a feeble old man and partially paralyzed he had sought to make a last stand in his labors against the grim old monster that conquered him a few months later. After many hardships he reached these great mogotes only to be driven away by the natives as a suspicious character. Next in line comes the precipitous Mogote de la Mina towering like a volcanic cone amid a fringe of lower hills; then, just opposite us, arises the almost vertical twelve hundred feet wall of the Costanera de San Vicente -ending abruptly in a deep narrow pass. This is followed by the equally abrupt walls of the Costanera del Abra. Off to the western limit of vision could be seen the curiously shaped Mogote de Pan de Azucar, and lastly, the indistinct mass of the Sierra de Pan de Azucar.

Various members of our party had at one time 
or another visited most of these mountains, approaching them by horseback trail through other ranges to the south, but Guajaibon on the east and Azucar on the west remained terra incognita to all of us, and were two of the main objective points of this trip. How best to reach them we did not know, but from some points along the coast we proposed making dashes for them, however difficult the way. Those who have "hiked" only in temperate regions can hardly understand worrying about a matter of ten or fifteen miles. In the tropics, however, there is a difference. Exuberance of spirit and that do-or-die feeling one has in the northern wilderness ooze out after a few hours' struggle in a tropical jungle.

When partial order had been attained and the launch was transferred to the water, a party was selected to go dredging, and another, in the auxiliary, to visit an island not far away to explore for Cerion. Our search for Cerion was neverending. The various species of this interesting molluscan genus reported from the northwest Cuban coast are little known, and as all of us secretly entertained theories about the evolution of this group of salt-air-loving land-shells, we were 
always keen about collecting them. The dredging party (Clapp, Simpson, Bartsch, Greenlaw, and myself) explored the shores of a key and the waters of a pass between the key and the mainland, making a number of shoal-water hauls on soft weedy bottom. The results were a large number of holothurians, large starfish of several species, some common sea-urchins, many worms and anemones, and a few large mollusks. The sieved dredgings later showed many small species of mollusks of considerable interest. At one point we discovered an old tree lying in about five feet of clear water. Making fast to this, we began a systematic search among the submerged trunk and branches for the many forms of marine organisms that seek such stations, and a notable catch of crustaceans rewarded our efforts. It was here that Simpson in his enthusiasm jumped overboard forgetting to remove an unforgiving watch.

Gill, with his paints and brushes, now being provided with material, started upon his labors which never ceased during six weeks of strenuous collecting. From this time on there was never a moment during the hours of daylight, except when the schooner was actually under way, that there was 
not at least one party in the field, and the steady acquisition of specimens necessitated constant work aboard, sorting, preserving, packing, and otherwise caring for the catch. Many of the specimens required unusual care and attention, such as those needing expanding by narcotizing. All material brought in called for immediate attention, and often the entire force worked far into the night in order to be able to "start at the beginning" the next day. When collecting was good we scarcely took time to inspect our specimens, so great was the hurry to save them. It was in this continuous scramble for results, this never-ending work, that we found keenest delight and abounding health.

In the afternoon great storm-clouds enveloped the mountains and a chilly wind from the northeast, the regular trade, whipped the open "bay" of Esperanza into a white-capped flutter causing the launches to dance a veritable rumba astern of the more steady lying schooner. Dr. Torre was engaged forward in a conspiracy involving ice and the grinding of a freezer, so that evening, when Captain Eduardo Tapia, captain of a Cuban revenue cutter, came aboard, resplendent in his 
uniform to pay us an official visit, we could offer him helado de guanabana-or soursop ice-that delicacy of all Cuban delicacies. When the Americans discover guanabana as a flavoring for ices and beverages there will be a great trade in this delectable fruit. We blessed Torre for this nice little attention. Our first dinner on deck was in a stiff breeze that blew the arroz amarillo off our forks. We had not learned then, as we did later, how to protect ourselves from the elements.

The Cerion hunting party met with no success whatever. Their island proved to be merely a mangrove flat harboring swarms of mosquitoes. They made some good dredge hauls, however, in two fathoms of soft bottom near Cayo Arenas.

We slept fully dressed and under blankets, this, our chilliest night on board. 


\section{CHAPTER III}

\section{Esperanza to Cayo Hutia}

Tuesday, May I2th. A superb morning. At 7 A.M. the air temperature $75^{\circ}$; water $82^{\circ}$. One cannot resist going overboard with such temperature combination, in water clear as crystal, and bottom at fifteen feet seen as through a plate glass. The morning dip was always a joyful function tempered only by one element of reserve-sharks or barracuda-here called picouas. The subject of sharks was one that always could be relied upon to precipitate a discussion on board that assumed as it progressed all the outward signs of an anarchistic rally. Men of the Latin race enter upon arguments with an earnestness and amount of feeling that perplexes the Anglo-Saxon. Is it not likely, he asks aside, that these men will do each other violence? Our fish expert (Lesmes) cherished gruesome memories of sharks and he was positive that they are always very dangerous. His eyes gleam with apparent rage; with quick threatening 
gesture he suddenly approaches his disputant and hurls at him an argument like canister hot from the cannon's mouth. The other staggers, but recovering from the charge and reinforced by others who rush into the wordy affray, he delivers back an argumentative broadside and the battle is on. We of the north glance at each other apprehensively. Something really should be done to quell this riot before our fine crew is destroyed or we ourselves, as innocent bystanders, shall be injured. Then the cook announces that coffee is ready and the dove of peace flutters in and the shark swims out.

This shark debate was never settled. Apparently there never will be a unanimity of opinion on the subject. There are, however, certain incontestable facts to be accepted in any shark discussion: first, there are sharks everywhere in Cuban waters and big fellows too; second, thousands of people enter the water and are not attacked; third, there are authentic cases of "accidents." A careful sifting of evidence from many sources, reliable and otherwise, tend to show that the Antillean shark is not nearly so dangerous as are certain species living in Australian and South 
Pacific waters, but he will sometimes attack a man. In shallow water (fifteen or twenty feet), especially if clear, sharks are timid. Close to a boat anchored where the bottom can be seen, a bather is quite safe. In deep water even near a boat the risk increases. A long swim away from a boat or the shore is not to be advised. If there is blood in the water from a wounded man or fish, a bather is in real peril. There are certain places where sharks prowl about for food, such as city dumping grounds, fish-cleaning docks, slaughterhouses near the shore, etc. To enter the water there, would, of course, be attended with danger. They are in fact indifferent lazy creatures of a low order of intelligence that become instantly aroused to a frenzy of activity by the smell of blood. At such times they will attack anything that moves,--even each other, and are of course exceedingly dangerous. We relied upon the Patron's advice entirely and only kept out of the water when he actually warned us, and this was seldom. Indeed we dived into the deep pools of the sand-bars near the reef where sharks abound and were often in sight, but we dared not jump overboard in Bahia Honda or Cabañas harbors where never a shark was seen. 
As to the picoua danger, not much can be said beyond mentioning the general fear of this aggressive fish. He resembles a huge pickerel or muskalonge with protruding jaw armed with very long sharp teeth. He prefers rocky places about the reefs, especially in the deeper passes, where, lying motionless near the bottom, he darts at his prey with a swiftness that baffles the eye. His sinister appearance, astonishing quickness, and occasional habit of ranging the waters in schools, like squadrons of submarine destroyers, have combined to give him a bad name. This is the "barracouta" (Sphyrcena barracuda) of Florida and Bermuda, a well-known game fish. The maximum length is about six feet. As a matter of fact we feared these far more than the sharks.

Promptly at seven a field party started in the launch for Cayo Arenas to make a more thorough exploration for Cerions and to study the abundant bird life there. Torre, Lesmes, and some of the crew went ashore for final marketing. At noon all were mustered aboard and preparations for sailing began.

A fine northeast breeze sprung up in the early afternoon. At three we were under way, the 
Patron climbing the mast better to locate the channel. Our course took us between the island and outer reef through a passage of ten or twelve feet depth, the bottom soft and weedy. The freshening breeze from astern drove us along "wing and wing" at about six knots, the sea making up enough to cause anxiety on the part of some who had not yet found their sea legs. At 7.45 P.M. we anchored near Hutia Light, under shelter of a little sandy key. As this little islet lies close within the coral patches we looked forward eagerly to the morrow for our first introduction to the actual reef.

After dark we experimented with the submarine light with most gratifying results. This is simply an electric light bulb enclosed in a waterproof globe and connected with a storage battery by a heavily insulated cable. Lowering this light into the water, a vast quantity of small marine life is attracted to it which may easily be captured in scoop nets of cheesecloth. Large fish will not approach, but the smaller species, along with myriads of small crustacea, worms, larval forms innumerable, small cephalopods-that host of creatures referred to as "plankton"-simply 
swarm about the light. Fish up to four or five inches in length circle rapidly about it forming a revolving wheel of some eight to ten feet in diameter. This we called the "Life Wheel." Inside this revolving circumference and nearer the bright bulb, myriads of plankton dart about confusedly as though greatly excited and fascinated by it. This method of fishing brought easily and quickly to our collections a great quantity of organisms that otherwise could only have been captured by uncertain laborious process. The amount of our catch differed very greatly according to type of bottom and possibly to weather conditions. This was one of our most successful nights with the light. Until one has actually had experience with the submarine light one can form no true conception of the abundance of living organisms that swarm in the warm sea water of the tropics. Within the circle of bright light about the bulb every cubic foot of water harbors at least a hundred living creatures without counting a vastly greater number of organisms not visible to the naked eye. Probably seventy-five per cent. of the whole are larval,--velagers of mollusks, the megalops of crustacea, newly hatched medusæ, etc. 
A large proportion of the total assemblage are more or less transparent displaying their internal anatomy with the clearness of an idealized drawing.

Before transferring the plankton to formalin it was always placed in bowls of sea water and about these our crew would gather in fascinated gaze, their curiosity seemingly never satisfied by closest inspection of the undreamed of wonders of the sea. They had thought they knew their sea so well. After all, all knowledge is relative. Possibly we who explained these things to the crew knew but little more about them than they, and possibly those who have dedicated their lives to these busy little creatures in the bowl know but little more about them than we. The recollection of a political campaign speech kept intruding, where the frank orator prefaced his remarks by saying: "You know nothing about the silver question and neither do I, therefore I shall explain it to you." 


\section{CHAPTER IV}

\section{Cayo Hutia and the Reef}

Wednesday, May I3th. Cayo ${ }^{x}$ Hutia is a real island and not merely a mangrove swamp as all of the keys so far examined had, to our disappointment, proven to be. We landed near the lighthouse first to make a search for Cerion, as the low-lying shore vegetation seemed to offer a favorable station, but we found none whatever. Myriads of jejenes (the Florida "sand-fly" and the northern "punkie") assaulted us as we waded ashore. The jejenes are a veritable scourge along the coastal strip of Cuba. They are too small to guard against by use of ordinary netting and their bite is peculiarly poisonous to the newcomer. One eventually becomes more or less inoculated and immune against the venom of their bite which then leaves little or no after-results, however annoying at the time. Fortunately the tiny insects cannot operate if any wind is blowing.

rThe words "Cayo," "Cay," and "Key" all signify an island. 
Our stay on Hutia Key was short, for the call of the nearby reef was very urgent. Beyond the little sand key we could distinguish dark patches of this reef with water swirling about them. There was not enough sea at the time to break over them and conditions were ideal for a visit. Those of us who were especially keen about marine mollusks were always hoping to discover a reef exposed at low tide upon which we could prowl about and overturn the dead coral rocks for our treasure trove beneath. Such places are not infrequent along the Florida Reef, and some of them had afforded us in times past most profitable hunting grounds. Along the entire extent of the Colorados we never encountered a dry spot, though there are many patches where coral heads come within a foot of the surface.

Fully equipped for reef work the entire company, excepting Torre and Lesmes, proceeded in the launch to the sandy key. Each carried a water glass and as many receptacles for specimens as he could manage; several brought sieves and one a 'demijohn of copper-sulphate solution for "doping" the hiding-places among the corals. All wore shirt, trousers, and canvas shoes. Wading along the 
edge of the key disturbing many nesting birds we rounded its northern end and struck out directly for the reef some two hundred yards beyond. Approaching this, the sandy bottom, at first soft with grassy patches of Thalassa, becomes hard, smooth, and dotted with gorgonians, sponges, huge starfish, and quantities of short-spined seaurchins and many large holothurians. Occasional small living coral heads (Mceandra areolata) appeared and an increasing amount of dead coral blocks. About the edges of such patches of dead reef rock waved many plumes of large branching hydroids. We waded out cautiously to where the water was breast deep. We were then upon the inner edge of the main reef upon which any further progress would have been difficult on account of the rapidly increasing number of the long blackspined sea urchins, the diademas (Centrochinus setosum), and because of the increasing irregularity of the bottom. Caverns opened to view displaying floors of gleaming white sand and literally swarming with fish. From holes and crevices in the dark-colored rocks projected the long antennæ of the large spiny-lobster or crayfish (Panulirus argus), and a general scuttling about 
of lesser crustaceans was sensed if not always clearly seen. Ponderous-looking fish (Groupers) frequented the deeper spots and lazily swam out of our range of vision. Occasional schools of fish of about four to five pounds' weight approached us and suddenly taking fright would turn in perfect military precision and dart away. Around and about all the coral heads and openings in the rocks, gorgeously hued small fish lingered quite indifferent to our presence so long as we remained still, but vanished at any sudden movement to reappear cautiously in a moment. These brilliantly painted reef fishes which represent numerous species and genera are one of nature's living color marvelslike butterflies and orchids. Their conspicuous colors are not protective in any simulation of their surroundings but it is quite possible that they are protective for quite the opposite reason. Their would-be enemies possibly can more quickly recognize in these metallic-hued creatures indigestible morsels that had best be left alone.

The interest of our immediate surroundings, however, was lessened by comparison with that of the wonderland in plain view just beyond us, on the main axis of the reef. This was not more than 


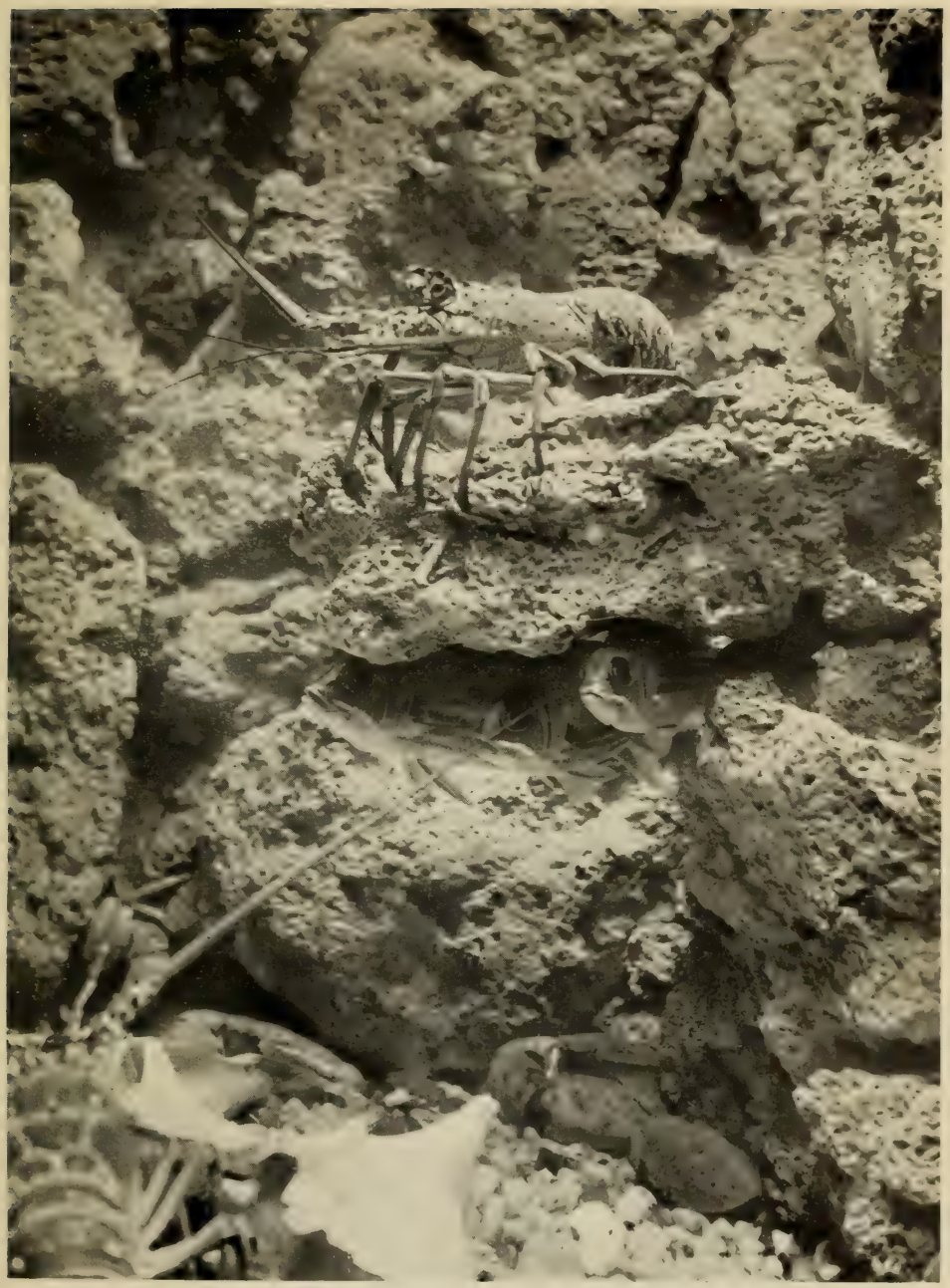

SPINY LOBSTER AND SQUIRREL FISHES

Photograph by Elwin R. Sanborn

Reproduced by permission of the New York Zoölogical Society 

fifteen feet away and could be perfectly seen by tilting the water-glass at an angle and gazing obliquely down. Through the refractive and magnifying medium of water, clear as crystal, all details were exaggerated in size and color producing an exquisite effect. As in some luminous gleaming atmosphere lay a dreamland where rocks and stones are alive, and miniature trees and huge flowers are animals; where the gentle swaying of its vegetation is indescribably graceful; where all is aglow in color and grotesque in form; where all is mystery and enchantment.

The thought comes that this prosaic water pail with its window-glass bottom has suddenly become bewitched, to enable one to peer into realms never intended for mortal gaze. But this fairyland of the sea, like some fantasy of the imagination, is no welcome place for the vulnerable body of a human being. Everything there, however beautiful in its soft liquid medium, is a merciless enemy. The black diademas, with long needle-sharp spines, would pierce his flesh, and the dreaded green moray eels lurking about would lacerate him like vicious serpents. The lovely little polyps that project like tiny pinkish and brown tufts from the 
myriad perforations in the coral heads would sting him to desperation with invisible nettles. And, at last, how far could the big lazy fishes be trusted, should a drop of blood scent the water. Despite all such warning reflections, what a longing possesses one to descend into this garden of the sea, to yield to the hypnosis of the rhythmic movements of its algæ, to creep into its mysterious caves and hobnob with octopi, the big pop-eyed groupers, and the rainbow-tinted fish that dwell within them!

Indeed it is usually the case that the most seductive places, those blessed spots that make the strongest appeal to the poetic imagination, are quite unfit for human comfort or safety. How often one sees some spot in the tropic jungle, smothered in cool green vegetation and seemingly dedicated by a kind Providence for a siesta, yet forbidden to all, save the newcomer to the jungle.

It was our object as far as possible to secure good specimens of every living thing, animal or vegetable, that inhabited the reef-obviously an ambitious program. We worked strenuously nearly all day. The Patron frequently gave us remarkable exhibitions of what might be called the 

"human amphibian." Inside the true reef, any object upon the bottom that was fixed too solidly for us to detach, he would secure by going down and wrenching it loose. He crawled along the bottom, examined into crevices, and extracted all manner of creatures that had taken refuge in such retreats. We had all flattered ourselves that when it came to diving for things we were not altogether inefficient, but we stood humbled before this aquatic man. We at once conceived a new respect and admiration for the Patron in whose own environment of jungle and sea we city dwellers could only make pretense.

Our experiments with the copper sulphate in open water turned out well, and by it many of the brilliant little fishes were stupefied and driven into our nets. While working about these coral heads in water, chest deep, we were at first amused and then annoyed by a gentle heave of the sea which persisted in lifting us off our feet and redepositing us just a few inches away from the positions carefully taken for best capturing our game. Again and again, when all was set to receive our desired specimen escaping from some crevice, a scarcely perceptible swell 
would gently elevate us all and our quarry would elude us. We had all been in the water far too long when suddenly one of our party relaying specimens to the launch broke into a lively dash for shore, and a commotion in the water near him raised the alarm of tiburon (shark). Although the shark in question was a very young one and evinced no interest whatever in us, we seemed then and there to lose enthusiasm. One casually remarked that he had reached his time limit in the water, and all felt that the balance of the day was none too long for the preparation and stowage of our material.

Needless to say, in so favored a locality as this, we made a notable and remarkable catch. This consisted chiefly in fine anemones, madrepores, gorgonians, corals, sponges, echinoderms, worms, crustacea, and fishes. The paucity of mollusks surprised us, although we took probably twentyfive or thirty species.

Although this was the first time we had seen any part of the actual Colorados, its conditions of growth at once suggested it to be of that class known as a "Barrier Reef." It occupies the outer edge of a submerged platform which it has prob- 
ably extended seaward to some extent by the well-known process of reef expansion. No better example could be presented than that before us to demonstrate the constant warfare going on between the upbuilding coral polyps and the hosts of destructive agents that tend to break down and destroy the reef. The greater part of the solid material on this particular patch is dead coral undergoing gradual disintegration by myriad boring organisms and giving to the mass of rock an indescribably rough and altogether fantastic appearance. Living coral polyps are constantly finding lodgment upon dead blocks of more or less altered coral rock and starting anew the upbuilding process. As might be expected such new growth is more apparent upon the outer or seaward portion of the reef, where, in general, the coral is more flourishing and appears to be growing with considerable vigor. On the inner side of the reef are many flattish blocks of complicated structure which appear to be fragments of coral once riddled and bored by worms and mollusks but now with crevices and holes filled with sand and calcareous mud and the whole apparently recemented together. In these blocks but little trace of the 
coral structure is noticeable although occasional shells are imbedded. The generally flat shape is probably owing to the polishing action of current swept sand. On the inner portion of the actual reef the conditions of life do not appear to be proper for very active growth of the coral polyps but entirely so for many other organisms of close relationship, such as anemones and sea-fans. Larger masses of dead coral observed explain their greater immunity from the various disintegrating processes by their coating of hard coralline algæ. These stony algæ are of exceedingly brilliant color and give to portions of the reef the appearance of having been painted in gorgeous hues. One cannot at once determine just how much of the massive rock floor of the reef is composed of older coral limestone once exposed to the air and recrystallized beyond easy recognition as ancient reef rock but now submerged again to form the base or foundation of the present reef.

I think we were all too much excited by the intense interest of the place, and too much affected by its loveliness to make the detailed and careful observations we intended. But other opportunities were abundantly offered us later on. 
Returning to the schooner in the afternoon we found that Dr. Torre and Lesmes had gone ashore at Santa Lucia to investigate the possibilities of making an inland excursion to Azucar, this being the point of nearest approach from the shore to that mountain.

Our first chubasco or rain squall struck us this afternoon. These chubascos within the northeast trade belt are very prevalent at this time of the year. They correspond in many respects with our northern thunderstorms but are usually more severe than the average summer shower of the United States. With threatening display of angry clouds, they arise with great suddenness, the wind reaching a terrific violence for a few moments; but the storm path is very narrow. There may or may not be rain or electric phenomena. The origin of these chubascos is certainly quite the same as that of our own thunderstorms. A hot sun expands the air, the colder upper air rushes in to fill the vacuum, condensing the moisture, and until the equilibrium is reëstablished a very lively row goes on. When conditions are right for their creation an extensive area may be filled with wandering chubascos that do not necessarily travel 
in the same directions. When they meet, little whirlwinds are born that occasionally produce waterspouts. These are miniature cyclones and explain very well the origin of the greater circular storms that so often cause terrible havoc in these latitudes during the summer months.

Our returning shore party announced that the trip to Azucar was not only feasible but easy of accomplishment on account of a road recently built by a mining company located some ten miles inland, and that horses could be obtained at the mine for the balance of the journey. In fact arrangements were already made for an empty ore wagon to take us the next morning to the mine. This was indeed good news. A party was made up of Torre, Clapp, Simpson, and myself. The khaki and boots were resurrected from the piles of clothing that littered the cabin floor, and all was made ready for an early start.

A dredging party in the late afternoon added another lot of specimens to our already overburdened table. These hauls were made in three to four fathoms (mud) and contained among the mollusks captured some very acceptable Tellinas.

Dr. Torre had obtained ashore a number of 
chickens and turkeys which were allowed their freedom on deck until coops for their reception could be hastily constructed. Luis and Mulatica, our dogs, resenting their presence, some of the fowl fluttered overboard. There is probably nothing so helpless in the water as a chicken or a turkey. These wretched creatures floated about frightened beyond making any effort to escape. We rescued and then regaled them with corn which they immediately ate as though nothing had happened. In a moment they were preening their feathers and uttering sounds of content. This instant recovery to a normal state of calm from a situation of the gravest peril seems to be a characteristic of all animals as distinguished from man. Cattle, wild with fright, will stampede, killing each other in their insane flight, and in another moment will be peacefully grazing. This sudden readjustment of the mind must be owing to lack of imaginative faculties. Man considers the horror of death or thinks of the pain and suffering that is about to be visited upon him. From the very intensity of his imagination he derives a physical shock that unbalances his entire nervous system. 
The day departed in a blaze of glory to the west. As darkness fell upon us great banks of cloud over Azucar seemed to expand with light as continuous threads of heat lightning played about them. Every trace of wind died out, the schooner floating in stolid repose. All was quiet excepting for distant squawking of water-fowl among the mangroves of Hutia Key. One by one we slipped away to bed, or nodded over the submarine light; but by 9 o'clock a pirate could have boarded us with heavy tread, save for Luis and Mulatica. 


\section{CHAPTER V}

\section{Santa Lucia to Azucar}

Thursday, May I4th. At a very early hour in the morning, Torre, Simpson, Clapp, and I left the schooner in the auxiliary amid a salvo of shouts consigning us to the care of God. Our equipment for the journey to Azucar, reduced to the very minimum, was all packed within one canvas bag that could be thrown over a saddle. The personal allowance for each consisted of one complete change of clothes. There were also some bags, small boxes, and bottles of spirit for specimens. We took neither provisions nor firearms; they are not required in Cuba. The food problem in most islands of the Antilles can only be solved in one way by the wanderer from the beaten path and that is by taking the essentials along. In Cuba there seems to be no region so remote but that some natives can be found, and wherever a native house is met, there is always food to be had 
and usually acceptable as to quality and cooking. In the little palm shacks or bohios, without floor or furniture or comforts of any sort, where grim poverty has hung out its ragged sign, hospitality awaits a stranger. Knowing that in some cases no remuneration would be accepted for food, our bag always contained certain knickknacks for the children. On one occasion after a serving of coffee when a dollar had been surreptitiously given a child, and we were quite a mile away, the father came running breathlessly after us to return the money.

Leaving open water, the auxiliary entered a muddy river winding about a jungle of mangroves and landed us at the mining company's dock, its point of shipment for ore. A little settlement at the landing is forlorn beyond description. It is planted in the most unhealthy-looking site imaginable and is still in the makeshift state of newness, evidenced by unpainted rough boards, and deep sticky mud. A species of huge horsefly with the bite of a cobra assailed us as we awaited our team for the trip to the mine eleven miles inland. All about are swamps of oozy black mud and buttonwood trees. Bubbles of gas from decaying vegeta- 
tion below charge the dirty water of many shallow pools. An army corps of fiddler-crabs scuttled about in the slimy mush and a fetid odor thickened the air. Clouds of mosquitoes and jejenes added to the discomfort of our half-hour's delay, and the heat was appalling.

We finally embarked in a big ore wagon for our slow journey inland. Passing the swamp region, which is but a narrow coastal belt, we entered a semi-open prairie country of gentle undulations. There many royal palms caress the eye and groves of live-oak, scattered about in park-like fashion, suggest the hand of a landscape architect. Lack of communication prevents this unpeopled stretch of rich country from becoming a garden spot of Cuba. This prairie belt is about two miles wide, and then begins the hilly region of pine-bearing elevations-the typical pine lomas already noted that flank the central sierras on both sides. These hills are not regularly aligned, but suggest a once elevated plateau, now eroded into a confused jumble of rounded knobs of from one hundred to five hundred feet. They are composed of soft friable sandstone and shale, iron-stained and disposed in strata much tilted, distorted, and twisted, 
and as far as we could discover, devoid of any fossil traces of organic life. The company road winds about through these hills with a gradual ascent following as far as possible the crests and ridges of the hills to avoid the washouts to which a valley course would subject it.

The vegetation of the pine hills is very scant for a tropical region, the royals entirely disappear and are replaced by another feather-leaf palm (Calyptronoma swartzi). On the slopes of the hills are occasionally found groups of Copernicia with gray leaves and slender stems, at this time in full bloom, though quite different from the stronger growing and richer colored species of the plain. Here and there in the valleys we noted a tree fern (Cyathea) which occasionally reaches a height of fifteen feet. In the lower parts of the hills was an occasional fine Ceiba, or silk cotton tree, but on higher elevations these are replaced by the Cashew-nut (Anacardium occidentale) which flourish everywhere in the poorest soil. The entire region is thinly covered with tall straight pines (Pinus caribaa) now mostly dead, the result evidently of the great hurricane of a few years ago. Whether this wholesale destruction of 


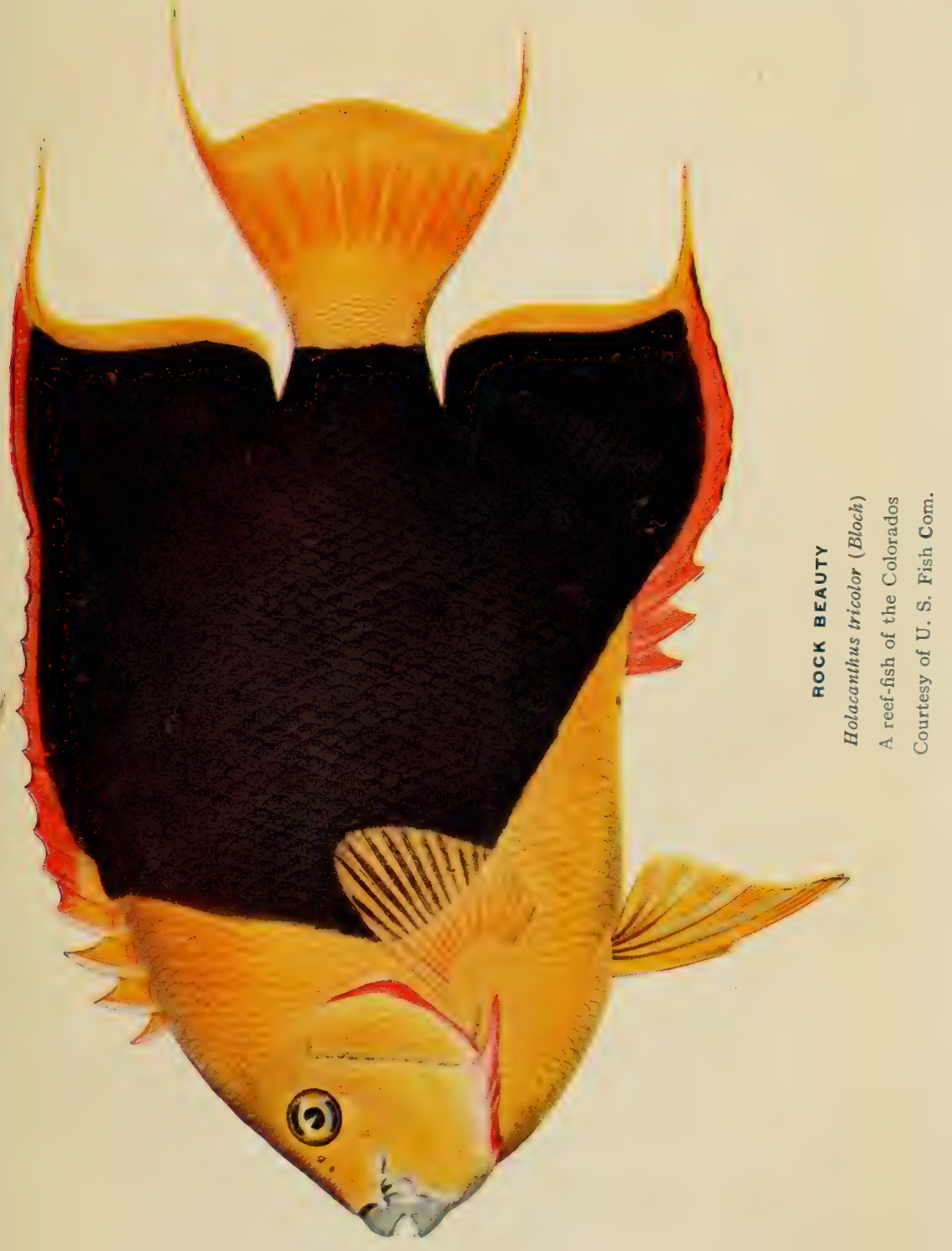



the pines which we first noticed at Esperanza was effected by the stripping of the leaves or by some unknown process of electrocution is impossible to say. The fact remains that millions of pines from the sierra to the sea and over an east and west extension of forty or fifty miles have been wholly destroyed, and yet there are but few evidences of the trees having been struck by lightning and but comparatively few blown down. The live-oaks here, always growing in patches, resemble closely the Florida tree, but probably are specifically distinct. A melastomaceous shrub, with spikes of white, and a Malpighia, with spikes of brilliant yellow flowers, now in full bloom, are everywhere found over the hills and form perhaps the bulk of the vegetation. Two pines are reported from western Cuba, but we were not able to distinguish here more than one. The ground is carpeted with a long wiry yellow grass. In general the flora is the outcome of the very poorest soil.

The hills become much higher as we approach our destination. A last turn brings into view the camp of the Matahambre mine, quite an imposing settlement. With a background of barren hills, it reminds one of mining camps among the 
foothills of Colorado. Here are all the essentials, the stables and corrals, the dormitories, the laboratories and machine shops, the residence of the officials, and perched upon the steep sides of the highest loma we had yet seen-Matahambreare the sheds covering two tunnel openings, with ore dumps trailing below. The Matahambre property, though still in swaddling clothes, has passed the stage of a "prospect" and is a mine of proven output and real value. It is privately owned and its stock is not for sale, a truly remarkable mining concern.

We were cordially received at the administration building by Mr. Morse, the director of the mine, and bidden to a luncheon of luxurious quality. With great kindness he had already arranged for horses. We were all provided with good mounts relieving us from the chief worry and fatigue of Cuban mountain travel. The trails in the sierras are often very steep and in the rainy season are always slippery. A horse not accustomed to them would soon come to grief, but even among the mountain ponies, there is a great difference. The best of them are sure-footed as goats and show much intelligence in negotiating a bad path, and on level 
stretches they adopt a fast walking gait or fox trot. Such a horse is a treasure but is not often for hire. The usual hired pony has a decided disinclination to accelerate his pace above a slow walk, hence the guide, upon his own good horse, gets far ahead, while we, in constant desire to catch up, must beseech and belabor our mounts. When we do manage to increase speed for a few brief moments, the result is a fearful shaking up. In steep and slippery places poor horses exhaust their riders more than themselves. We fully appreciated Mr. Morse's courtesy in securing for us the right kind of animals.

After luncheon we enjoyed an illuminating chat with our host when he gave us the benefit of his observations upon the geology of the region and the occurrence of ore beds in the neighborhood. His conclusions concerning the geological history of the mountains and the relation of their limestones to the flanking sandstone and shales did not fully coincide with our own somewhat hazy ideas, but we had to confess that our opinions on the subject were by no means fixed.

In a driving rain we set forth with our guide Alvarez leading the way up the steep Loma de 
Matahambre to its very summit (one thousand feet). From there we caught a superb view of Azucar and the ranges east and west. Between us and the sierra we could trace our route over many lesser lomas, the path zigzagging along their crests. After some two hours of travel we descended sharply into a valley where the vegetation suddenly assumed the sierra character, and blocks of white honeycomb limestone appeared beneath a drapery of leaves and the matted stems of creeping vines. Here, then, were the remains of an old mogote, far removed from the main sierra and possibly a treasure island for us. We dismounted in a hurry to explore the rocks, exhilarated by land-shell possibilities. A perfect little gem of a banded Eutrochatella (E. regina) of the Azucar type of coloration and sculpture, but of miniature size rewarded us, but there was nothing else of importance.

Throughout this region of lesser lomas we observed many low trees of a species of Spondias, bearing a plum-like fruit related to the Otahite apple, which is eaten by the natives. There are also several species of Ficus, among them $F$. crassinervia with leaves resembling those of the 
familiar rubber tree cultivated in the north for ornamental purposes. A number of species of small trees related to our hackberry and of the genus Celtis are noticeable features of the flora. One of these, Celtis aculeata, is armed with small hooked spines making it difficult to penetrate their thickets.

About dark we entered the valley at the base of Azucar (lower than the mine) and following the Malas Aguas River eastward along the base of the sierra we soon reached the tiny little settlement of E1 Punto. The tienda (store) at E1 Punto is made glorious only by the good will and intentions of its proprietor. Our arrival created considerable stir among the population who no doubt wondered why three Americanos and the distinguished professor of Havana should turn up at the Pan de Azucar. When they discovered that we were naturalists, the youth of the village started in then and there to collect anything and everything that they thought might interest us. It was night when we arrived quite ready for bed, but we were obliged to remain up for some time to receive the consignments of fireflies, bats, and other objects that the boys brought in. Not until the proprietor 
of the inn closed and barred his doors for the night could we retire to the "guest room." Soon there were no sounds to disturb our sleep except the scurrying of innumerable rats.

While the shore party was on its way to Azucar, those remaining on board the schooner put in a busy day. At 5.30 A.M., Bartsch, Rodriguez, and the Patron, with Greenlaw, again visited the reef and some sandspits off the north end of Cayo Hutia. They ran a line of dredgings between the coral patches of the reef, taking bottom samples but finding little life. In the early afternoon a shower of three inches fairly deluged the earth. Later, Bartsch, Gill, and Greenlaw, made another series of dredgings along the mainland shore taking some new starfish and a quantity of small material. In the evening the opportunity offered by a perfect calm was taken to try out the submarine light on the reef. A position was taken in ten feet of water immediately over a large mass of Acropora palmata. The results were excellent in a fine lot of small crustacea, worms, and plankton. A second station occupied over a grassy patch also yielded good returns. 


\section{CHAPTER VI}

\section{Pan de Azucar}

Friday, May 15 th. In all tropical regions, the forests and open glades appear to reach their acme of splendor in the early morning hours. This is not owing simply to atmospheric effect, which we so much consider in the viewing of all landscapes, but because of the freshness of the vegetation and the reawakening of all life at that time. During the prolonged heat of a tropic day, all nature seems drowsy. The birds cease their calls and disappear; insect life is less in evidence and the vegetation itself loses in vigor. After the cool of the night and a refreshing dew bath, the coming day is greeted by a general rejoicing. Every plant thrusts forth its leaves to absorb the sun's rays while still tempered by morning mists. All animal life is rejuvenated and busily sets about its day's task with a vim that begins to flag by nine and is dissipated by ten o'clock. This, of course, 
does not apply to the night-prowling creatures whose daylight hours are spent in concealment, but they, however, do not figure in the visible forms that make up our tropical scene.

This same stimulus of the dawn is felt by man himself. Indeed, below $23^{\circ}$ latitude, the success of the day is largely dependent upon an early start. In the north there is no such hour upon the calendar as 4 A.M. In the tropics it is the beginning of the best hours for accomplishment.

At daylight we emerged from our guest room, assisted our host to remove the barriers from his doors, and then for the first time we saw Azucar at close range. Directly before us arising precipitously a thousand feet and heavily draped in dense vegetation it presents every feature of the typical sierra.

The east and west extension of the mountain is about five miles. Farther to the west and separated from Azucar by a valley of a mile or so in width arises the large mass of Peña Blanca-a mountain belonging to the series of north and south axis that terminates to the south in a series of high mogotes about Guane and Mendoza. Azucar, itself, marks the western end of the ranges having 
an east and west axis, and belongs rather to that particular series called, about Viñales, the "Sierra de Viñales" and the "Infierno." It is not therefore an integral part of the Costanera, or northern range, which is in plain sight from the sea, although it has every appearance of being a detached extension of that northern system. Between the western end of the Costanera and the eastern end of Azucar (centered in a gap of five or six miles between them) rises the conical Mogote de Pan de Azucar. The land-shell affinities of Azucar at once showed its connection with the Viñales range and not with the Costanerato which latter system belongs the large conical mogote. It was partially to determine this fact that we were here, and our eagerness to get started, while we awaited our horses at the door of the inn at El Punto, made each minute seem an hour. We set forth at length with a definite plan of attack that should enable us to accomplish the most and cover the greatest possible area in the one full day at our disposal. Simpson was to begin collecting immediately in front and work west-to the end if possible; Clapp and I were to take the eastern end and work back, while Dr. 
Torre and Alvarez were to go on for an examination of the mogote. This sharp peak is so important a landmark to sailors that it has come to be called the "Pan de Azucar." The name is, however, erroneously given, for the true "Pan" is the greater mass of the sierra itself, and the so-called "Pan" should be the "Mogote de Pan de Azucar." This is in conformity with the localities given by Arango when he visited Azucar, and the name is correctly given upon a map prepared by American army engineers just after the Spanish War.

There is need of better maps of this entire region. The old standard maps of the Spanish cartographers, made half a century ago, are very incorrect, and their lack of topographical data is a serious omission. A few sheets prepared by the American engineers covering parts of this region, though hastily prepared and without careful triangulation or positive measurements, are reasonably correct.

Leaving Simpson to attack the Pan at the nearest point opposite, the balance of us rode off to the east, fording a river and following the valley along slippery trails. At a point about three miles east of the tienda and near the east end 
of the mountain, Clapp and I stopped. Here is the house of one Rodriguez who raises tobacco and gathers mangos and cocoanuts from old trees surviving the destruction of the ancient finca (farm) of the rich Francisco Marti. At the very foot of Azucar this beautiful place, enclosing a large area within the fertile valley, was once a famous estate. Ruins of stone buildings now in picturesque decay attest the importance of the place when Pancho Marti, now many years dead, lived here in true country gentleman style. A gloomy atmosphere now broods over the fields the jungle is reclaiming. The fine fruit trees are sadly neglected, and the once symmetrical rows of palms have followed nature's less orderly scattering of their seed. Amid these stone ruins are now the floorless thatch houses of the present proprietor upon whom poverty and isolation have set their mark. But no heartier welcome could have been offered the stranger by the departed Marti than is now offered by the living Rodriguez. He picketed our horses and bade his rather pretty young wife to fetch coffee. She returned with a pot of coffee in one hand, a baby supported on her other arm, and a torpedo-like cigar between her 
lips. It was at this very spot that Arango stopped fifty years ago and made the first scientific exploration of the region. Since that time the mountain has not been visited by naturalists, or at least no published records of such visits exist.

Notwithstanding the labors of Charles Wright, who, as already noted, for four years collected the Cuban plants for Asa Gray and Ghiesbach, it would seem that the botany of the sierra is even yet very imperfectly known. Standing at the base of Azucar-or any other typical sierra of the Organos ranges-one is a little dazed by the heavy mass of vegetation composed of an infinite number of species of trees and shrubs. The lower portions of the sharp elevations are densely covered with a tangle of vegetation almost impossible to penetrate. The "pull and haul" vines (Pisonia aculeata), that in the more favored situations attain almost the dignity of trees, present a barrier as effective as barbed wire. The curved spines of this vine point in two directions and are so disposed upon the stems that they catch and hold the bewildered victim in a double grip tearing his clothes and lacerating his flesh. It was to us a frequent occurrence to become so hopelessly 
entangled in their painful grasp that without aid movement in any direction was impossible. Throughout this mass of vegetation along the base of the mountains (and up for a short distance) Celtis aculeata, a small tree with short stout spines, is always encountered, and one must constantly be on guard against grasping this tree for support. Among the wilderness of vines, the spineless Pithecoctenium aubletii binds the forest in every direction and is ably assisted by another spineless creeper, with stems of rope-like strength (a Chiococca), which often makes a tangle defying penetration. These lianes catch one's feet, bind one's arms, or encircle one's neck in the most exasperating way. Another, and one of the most curious of all the creepers, occasionally met in such stations, is the Bauhinia heterophylla. The stem of this luxuriant plant is flat and so moulded as to resemble a heavy anchor chain. These ponderous "chains" lie along the ground, sometimes twisting one about another and finally ascending out of sight in the foliage of the highest trees. It possesses bilobed leaves disposed in pairs, each leaflet separate. Everywhere is a mixed assemblage of tropical trees that cannot at once be determined 
by the botanist-a perfect wilderness of rich, lush, bright green vegetation.

An abundant tree on Azucar is the Gliricidia platycarpa with compound leaves and bearing a pink flower very similar in form to our own sweet-pea blossom. Among other flowering trees there is an Erythrina, also with large compound leaves, which bears long clusters of dazzling scarlet bloom. They illumine the dark green of the forest like elfin beacons. Another tree of very scant foliage bears a vivid yellow flower growing directly from the trunk or larger branches-a peculiarity quite startling to the northern beholder. Another yellow flower is that borne by the vine, Mucuna urens, an abundant creeper throughout the sierra, which climbs to the top of the tallest trees. These flowers hang in clusters and are succeeded by large prickly seed pods in which nestle the red and black "sea beans." These beans, when washed down to the sea, float indefinitely, and many of them are eventually cast up on the Florida beaches. When polished they are sold for ornaments or charms against evil fortune. It is generally understood that no one carrying a sea bean in his pocket can 


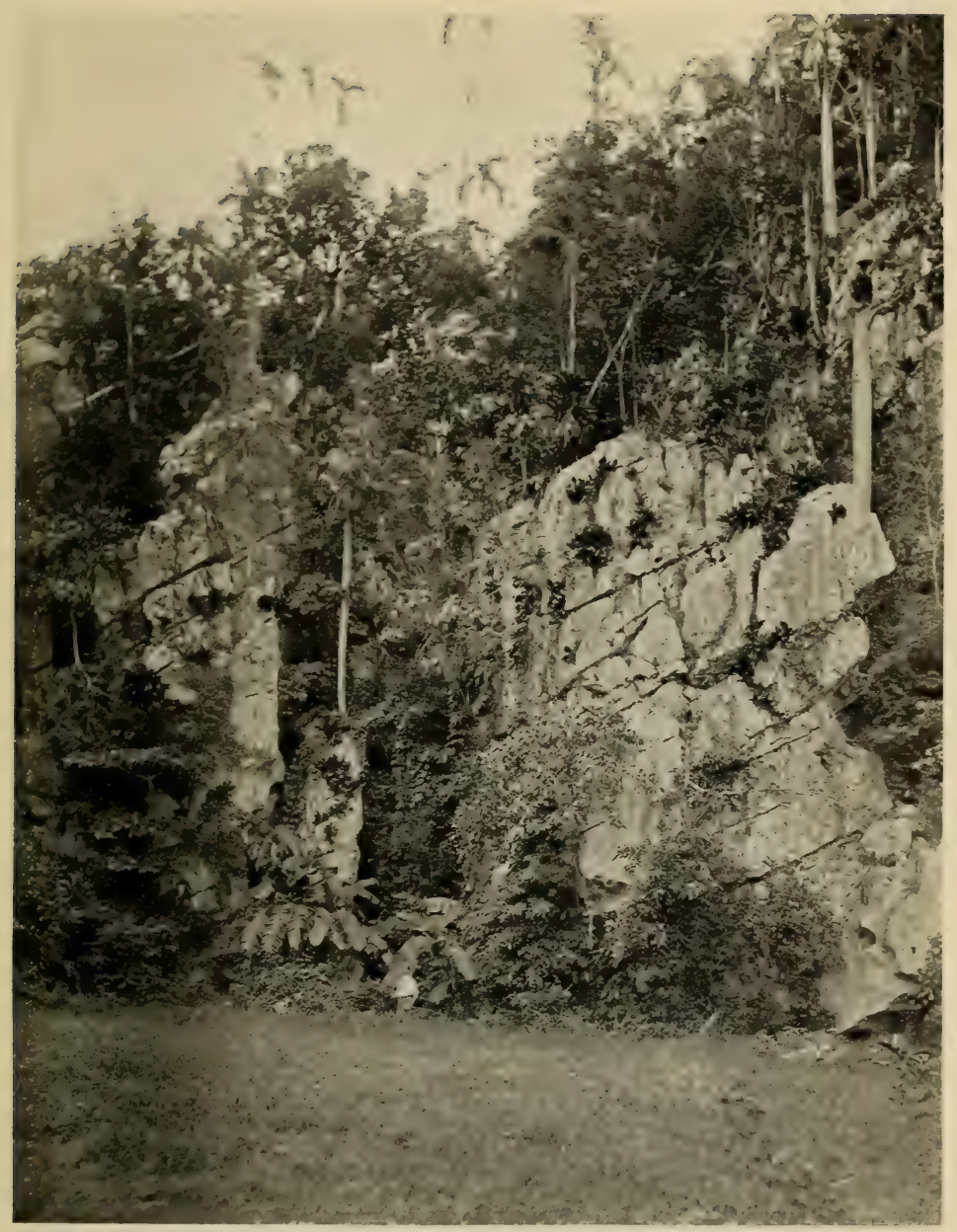

A MOGOTE NEAR VIÑALES SHOWING SIERRA VEGETATION

Reproduced by permission of the American Photo Co., Havana, Cuba 

suffer harm through that bogy of bogies-Bad Luck.

Some of the most remarkable growths of the sierra flora are the Clusia of various species, though chiefly $C$. rosea. This diabolical tree begins its career as an innocent-looking little vine clinging tenderly to some great tree as it pushes its tendrils upward to the sun and light. Gradually it envelops the tree in a network of green stems which, growing larger and stronger, bind the tree trunk in an ever tightening grip. In the meantime the upper reaches of this remorseless vine in a deadly caress is choking the leaves of its host. Gradually the spaces between the vine stems fill up as they expand, and finally the original tree is completely enveloped in a solid casement and soon dies for lack of air and light. As the wood of the dead tree decays, this curious plant grows in, filling the hollowing space and becomes an endogen or complete tree. This Clusia is but one of many plants of similar habit, but it exemplifies in the most cruel fashion the remorseless warfare of the jungle. Here, indeed, is subject for thought. Is there "justice" in nature? Does nature recognize a right and wrong? Is there any right and 
wrong beyond the creation of those terms by man? In the vegetable kingdom we may assume that the life process goes on guided only by that invisible, unknowable force within, and free from any possible influence of mental perversion, and yet for this vine to reach its maturity and bear seed it must destroy another life, and this without animus or enmity or the excuse of self-defense. It is a wholly unconscious process. Nature study forces the conclusion that "right" and "wrong" are social rather than natural considerations.

I have already referred to some of the commoner thorny plants of the sierra, but one is so devilish in its ingenious arrangement of spines that I must mention it. This is the Malpighia urens, a large shrub with lanceolate leaves which carry upon their borders small forked spines pointing in two directions and delicately attached to the leaf edge by the slenderest thread. These become detached by the slightest touch and painfully injure the flesh. There is also one other "aggressive" plant frequently encountered about the base of the sierra -the "cow-itch" (Mucuna pruriens). This villainous ground-creeper bears a fuzzy brown seed pod liberally sprinkled with microscopic spicules. 
When dry, these spicules are scattered into the air by any disturbance of the vine and falling upon the skin produce an irritation which drives one almost frantic.

Climbing higher up the talus of limestone blocks, the area of densest vegetation is soon passed, and among many species of large smooth bark trees, all more or less bound in lianes, a number of long slender-stemmed palms are met, the Gaussia princeps, with bottle-shaped base. There are usually a few royals and several species of Thrinax with fan-shaped leaves. At an elevation of about one hundred feet the top of the talus is reached, and there begins the perpendicular paredon or wall which rises anywhere from twenty to several hundred feet. Its face may be a solid smooth expanse of white rock offering no foothold whatever for vegetation, or it may present interruptions in its even surface furnishing narrow shelves where vegetation can find lodgment. From such situations exceedingly narrow-stemmed palms (Euterpe mancle) rise to great height, and many cacti and agave plants cling to their insecure perches. Of the numerous cacti the most prominent is the climbing Cereus pitajaya whose rounded small 
stems, covered with little acute spines, festoon most of the large boulders exposed to the sun. Rhipsalis, with long slender drooping stems, hang from high places; and in crevices, sheltered from the strong glare of the sun, many species of ferns find lodgment. One of the most remarkable objects of the very steep slopes of high altitude is a green, smooth-stemmed tree with swollen barrel-shaped trunk, small head, crooked branches, and almost no leaves whatever. The roots of this extraordinary tree are long, smooth, sinuous, and bright green, wandering over and under the rocks like great snakes. They feel soft to the touch and give a shock to the climber, who, with nerves already on edge by reason of insecure position, fancies, for a dreadful moment, that he has seized a boa.

One of the most strikingly beautiful objects in this bewildering botanic exhibit is a soft wooded tree with immense palmate leaves which are dark green above and silvery white beneath (Cecropia peltata). In a breeze these great leaves flash their white under-surfaces in alternation with the rich green of the upper portion, making a moving picture that fixes an exclamation point in one's confused memory of an overwhelming flora. 
At the time of our visit to Azucar the rainy season was well on. The warm moisture-laden atmosphere insured ideal conditions for the collector, though not for his personal comfort. Passing the heavy belt of vegetation at the mountain base to attain the steep talus of limestone blocks, now dripping wet, we fell upon a collecting experience most pleasant to dwell upon in retrospect. Creatures theretofore sought by laborious overturning of many rocks now in astounding abundance appeared in open sight. It was not a question of searching for specimens but rather one of selection of the best from many. Among land-shells the large Pleurodonte guanensis, with its elongate corrugated body fully extended, crawled about in every direction, sometimes several individuals in sight. The vitreous Oleacina straminea, with yellow body and long tentacles, crawled rapidly over the rocks and vegetation seeking their living prey. Everywhere the big Helicinids of the Emoda group were active as well as the lovely smooth banded Eutrochatella regina, a varietal form confined to this one mountain. We reveled in a conchological paradise, soon filling our bags and every available receptacle, even resorting to the 
makeshift of folded leaves, handkerchiefs, and hats. Active myriopods darted about the fallen wet leaves, quantities of the milleped Iulus of more sedate habit ranged the rocks and ground, and a wealth of insect life invited capture.

While busily collecting, a flash of green and red darted past and lodged upon a shrub not five feet away-our first todi.

One of the most beautiful birds of Cuba is this little todi (Todus multicolor Gld.) which, excepting for the humming-birds, is the smallest of the feathered inhabitants of the island. Its entire length from the tip of bill to tip of tail is about $33 / 4$ inches. The entire dorsal parts of the bird are brilliant grass-green. There is a large throat patch of bright scarlet, bordered by a zone of white at the angle of the bill, which is replaced toward the posterior end of the patch by a bright blue. The under parts are white and smoky and the flanks are washed with a pale scarlet. This little jewel of a bird may be found anywhere in western Cuba, usually in low shrubbery bordering some path, and he invites your attention by a song, which recalls faintly a relationship to the kingfisher, for if one analyzes the kingfisher's rattling note by repeat- 


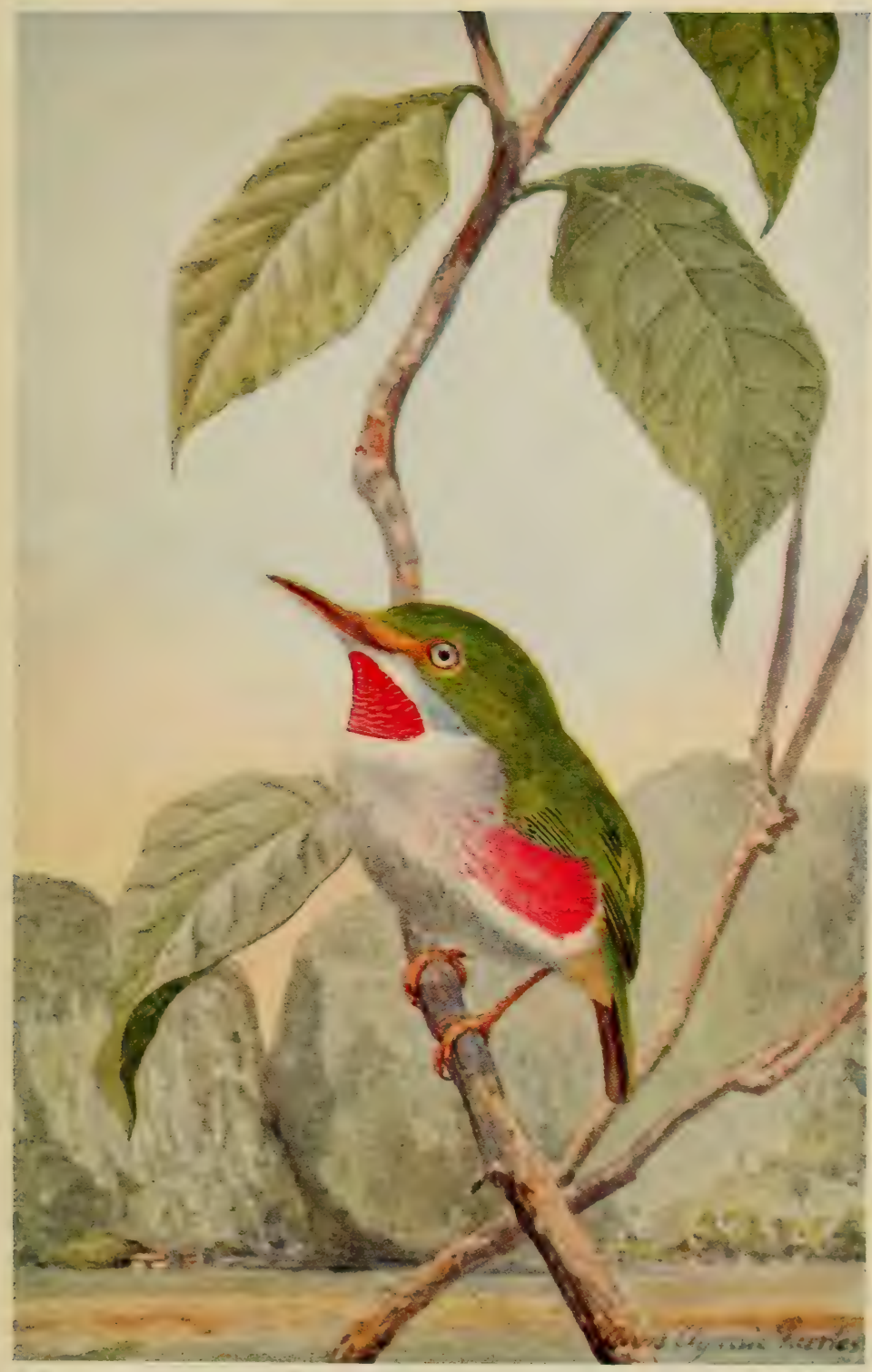

\section{CUBAN TODY}

(Todus mullicolor Gld.)

Drawn by Louis Agassiz Fuertes 

ing it slowly on a graphophone it gives a somewhat similar result. The song of the todi is chu-chu-chu, quickly repeated four to ten times. He has also another note that resembles his name, which is simply a call-note emitted at irregular intervals. The song, on the other hand, is often repeated, and once having learned this note, it is not at all difficult to find its source. The little chap is quite fearless and permits one to approach within a few feet while he sings for dear life, paying no attention to the intruder. In feeding habit they are flycatchers, snapping up insects on the wing, then returning to the perch and sitting quietly, with head drawn in, the beak pointing upwards, patiently awaiting the near approach of another victim. In nesting habits, however, they resemble the kingfisher, depositing their pure white eggs in holes which they dig in the banks of ravines or ditches.

The todies are peculiar to the Greater Antilles, one species being found in Cuba, two in Haiti, one in Jamaica, one in Porto Rico, and another of unknown habitat. They are general favorites with the natives on account of their excessive tameness and lovely plumage. The Jamaican 
species is known to the inhabitants as "robin redbreast."

We also encountered here-as almost everywhere in the sierras-the Cuban lizard-cuckoo, generally called by the natives the arriero, on account of his note so closely approximating the call of the plowman to his oxen-" cklk-o-o-o-o." This lizard-cuckoo (Saurothera merlini Orb.) is a rather large individual, about twenty inches in length, of which the long, broad tail makes up three-fifths of the entire length, while the bill adds almost two inches at the other end. $\mathrm{He}$ is a veritable clown, of curious, inquiring turn of mind and extremely amusing in his antics. $\mathrm{He}$ can readily be called by repeating his note. He comes very near, but always insists on keeping some branches between or at least he remains in the shade, thus rendering photographing difficult. Having responded to your call he will inspect you carefully, moving his tail side-wise, to almost right angles with the body or cocking it upward like a wren. He may then sneak away slyly, almost like a shadow, or he may spread his wings and tumble over himself, chattering away as if he had discovered the most amusing thing in the world 
and was bubbling over with mirth. At such times he is so comical that one cannot help joining in his laughter. The arriero is one of the most interesting members of the Cuban avifauna. The color of the bird is pale grayish brown with a metallic flush, the throat and the anterior part of the under surface are grayish, washed with pale brown, while the posterior portion is pale reddish brown. The large, broad tail feathers, excepting the inner ones, which are the longest, are tipped with white and crossed by a broad band of black just within the white tip.

During the course of the afternoon we surmounted a low crest at the eastern end of the Pan and entered a hoyo or crater-like depression within, on the floor of which some enterprising families cultivated tobacco. These hoyos, or sunken round valleys within the sierras, are another manifestation of the cave formations constantly going on. In the case of all hoyos the roof has long since fallen in and disintegrated into a soil of excessive richness, which produces by the most primitive cultivation a superior grade of tobacco leaf. As a rule the dweller within the hoyo must obtain water for his family use from rivers without, 
hauling it up the steep sides of the sierra, and then down again the equally steep sides of the "crater." The paths worn by his little horses seem hardly fit for a mountain goat to travel.

While perched high upon the rim of the circular valley, seeking to gather some arboreal Urocoptids from the trees and at the same time to take in the superb view, a thunderstorm of great severity burst upon us. Swirling banks of mist united to form dark clouds from which lightning leaped in terrifying flashes, and the thunder seemed to rock the mountain beneath us. In the presence of such a mighty manifestation of Nature's forces, man's natural powers of self-preservation are feebler than those of the lower creatures about him. He alone cannot afford to get wet for risk of illness. Every animate thing about him cares little for the wetting or even finds in it a positive benefit to his life economy. By a superior intelligence the human animal has built about him artificial protections-his armor of clothes and the fortress of his house. Just so much as he has done for himself his mother Nature has left for him to do. When suddenly stripped of his own self-devised guards, he stands naked among the wild creatures 
of the earth, the most helpless and vulnerable of them all. His sensitive skin cannot resist the sun nor stand a change of more than a few degrees of temperature. His tender feet cannot bear the touch of the earth. He is helpless before the common parasites and would fall before the attack of any animal of half his size and weight.

It was well towards evening before Dr. Torre and Alvarez arrived from their long ride to the mogote and to the Costanera beyond. They had remained at each just long enough to make a hasty collection of the land-shells in sight. The return journey to the inn was made in the dark over trails the more slippery by reason of rain actually falling, and the river ford had taken on an ominous look and sound.

Simpson awaited us at the inn not wholly satisfied with his portion of the day's work. The western end of Azucar had not proven as rich in mollusks as he had hoped, but he took a quantity of cuttings from shrubs and trees for propagation in his botanic garden in Miami, and many specimens for the herbarium. An experience during the earlier part of the day, of a kind which occasionally overtakes the mountain prowler and usually 
leaves him somewhat unnerved, had befallen him. He had just missed toppling over a height with a sheer fall of fifty feet, having saved himself by grasping a none too securely rooted tree which for a moment threatened to go over with him. Before fully recovering his equanimity and still hanging on "by all fours" he suddenly found himself gazing into the face of a maja or Cuban boa,-a not altogether sweet-tempered serpent of 8 to Io feet in length. Simpson, who is not a herpetologist, simply and tersely described the snake as a "big one" which gave such unmistakable evidences of displeasure at the interruption that his already excited nerves received a supplemental jolt.

Apparently all of the residents of E1 Punto were awaiting our return to the inn to present us with all manner of "curiosities" which they had gathered during the day. There were many fresh-water fishes and crustaceans and some interesting insects, among which were fine specimens of the large luminous beetle (Pyrophorus noctilucus L.).

These wonderful beetles are altogether different from the common North American firefly, and while no doubt the light-producing processes in both are the same, the two belong to quite distinct 
generic groups. These luminous elater beetles are distributed over entire tropical America and are represented by several species. This one is about an inch and a half long and of a black or rusty brown color. Its light is emitted from two oval yellow spots on the prothorax and one beneath extending over a portion of the metathorax and the first abdominal ring. Unlike our northern fireflies this beetle emits a steady continuous greenish light that glows with startling brilliance. The process appears to be wholly voluntary, for if disturbed (or when feeding) the beetle shuts off the light and as suddenly "switches" it on again upon resuming flight. The physiological-chemical reaction involved in the production of this light still remains a mystery. Experiments with the bolometer to measure the heat of the glow have given only negative results, although this sensitive instrument responds to the heat of a star. The luminous efficiency of the glow emitted by the beetle is remarkably high $-96 \%$, and is, for its expenditure of energy, actually the most efficient light known. The luminous efficiency of a candle, for instance, is less than one-half of one per cent.-for a tungsten electric bulb about $4 \%$. Notwithstanding 
this perfection of economy in the production of a light, the actual candle-power of the light is extremely low. On account of its rays being confined to green in the spectrum, the light emitted would be of little use as an illuminant, for it would distort all objects not of green color. The eye is most sensitive to green, and the firefly having produced a light that is restricted to the green spectrum has succeeded in producing a perfect light to be seen, but not a good light for the illumination of objects. But such is obviously not the purpose of the glow. It is almost certainly for sexual attraction of other individuals of the species. This beetle has the curious habit of all chickbeetles of "snapping" by a convulsive muscular movement causing it suddenly to leap without employing either legs or wings. The elfin beauty of the moving lights through the woods or over the fields is very pleasing to the sight and inclines one to accept again his childhood theories concerning fairies.

The party remaining on board devoted the day to a thorough examination of the shallow waters along the mainland shore and within the small lakes of the mangrove shore belt. The dredgings 
were not rich, although a number of mud-living forms, especially worms and some excellent hydroids, were secured. Of mollusca, they took several species of Tellina, one of Lavicardium, some large Bulla, and a number of the Veneridæ. Among the dead mangroves bordering the mainland Bartsch's party discovered a large rookery of water-birds. Here they observed large numbers of breeding Mexican cormorants, some of the nests containing fresh eggs, while others had almost fullgrown young. Here also were noted the anhinga or snake-bird; a pair of West Indian tree ducks, breeding in an old tree; some American egrets, the reddish egret, the snowy egret, the Louisiana heron, the little blue heron, the Cuban green heron, and a yellow-crowned night heron, all having nests in this colony. In addition to these they saw between two and three hundred white ibis, but could not locate their nests, but it is possible that the time of the visit did not coincide with their breeding period. This rookery Bartsch reported to be a rather large one, extending over a little more than a mile of the coast, and there appeared to be many thousands of birds occupying it. 
Hauls of the dredge in the middle of the bay on harder bottom brought up many ophiurans-one a new species, - and a number of Strombus pugilisan old mollusk friend of Western Florida waters. 


\section{CHAPTER VII}

\section{Azucar to the Coast}

Saturday, May I6th. As the rainy season had begun in earnest and an afternoon deluge could with certainty be expected, we decided to hurry back to the mine before another torrential rain should make the trails too bad for travel. A longer sojourn at Azucar, with a visit to Peña Blanca, would have been desirable, but the expedition schedule forbade more than three days for this particular inland trip.

The chief grievance of the student traveler of to-day is lack of time. The great naturalists of a generation or two ago, Wallace, Bates, Belt, Gosse, and many others of lesser reputation, who have left us fascinating accounts of their travels, spent years in the countries they explored. None can appreciate better than ourselves the inadequacy of a month or two in western Cuba for any real acquaintance with its natural history. A hasty 
visit, such as ours, can offer no more than a glimpse at the fauna and flora and that too only in its particular phase of the season, and naturally no attempts can be made to inquire into the life history of the creatures observed. One would suppose that the rapid transit of to-day, condensing months and weeks into days and hours, would yield to the collector additional time in the field. Such, however, seems not to be the case. Indeed, the very reverse is the result. The habit of haste has been bred in us, and we must gallop through paradise,time-table in hand. The coming aeroplane packets will still further shorten our days for travel.

With temporary packing for horseback travel of our very large catch of fragile material it was quite 8 o'clock before we swung into single file and began the slippery journey back to the mine. At the little mogote, surrounded by sandstone hills, we stopped once again to search more thoroughly for Urocoptis, hoping hereby to forge another link in our chain of animal migration and development, but no trace of this genus could be found, despite much grubbing about in the vegetation.

Banks of clouds that early indicated an afternoon deluge were forming over the mountains, 


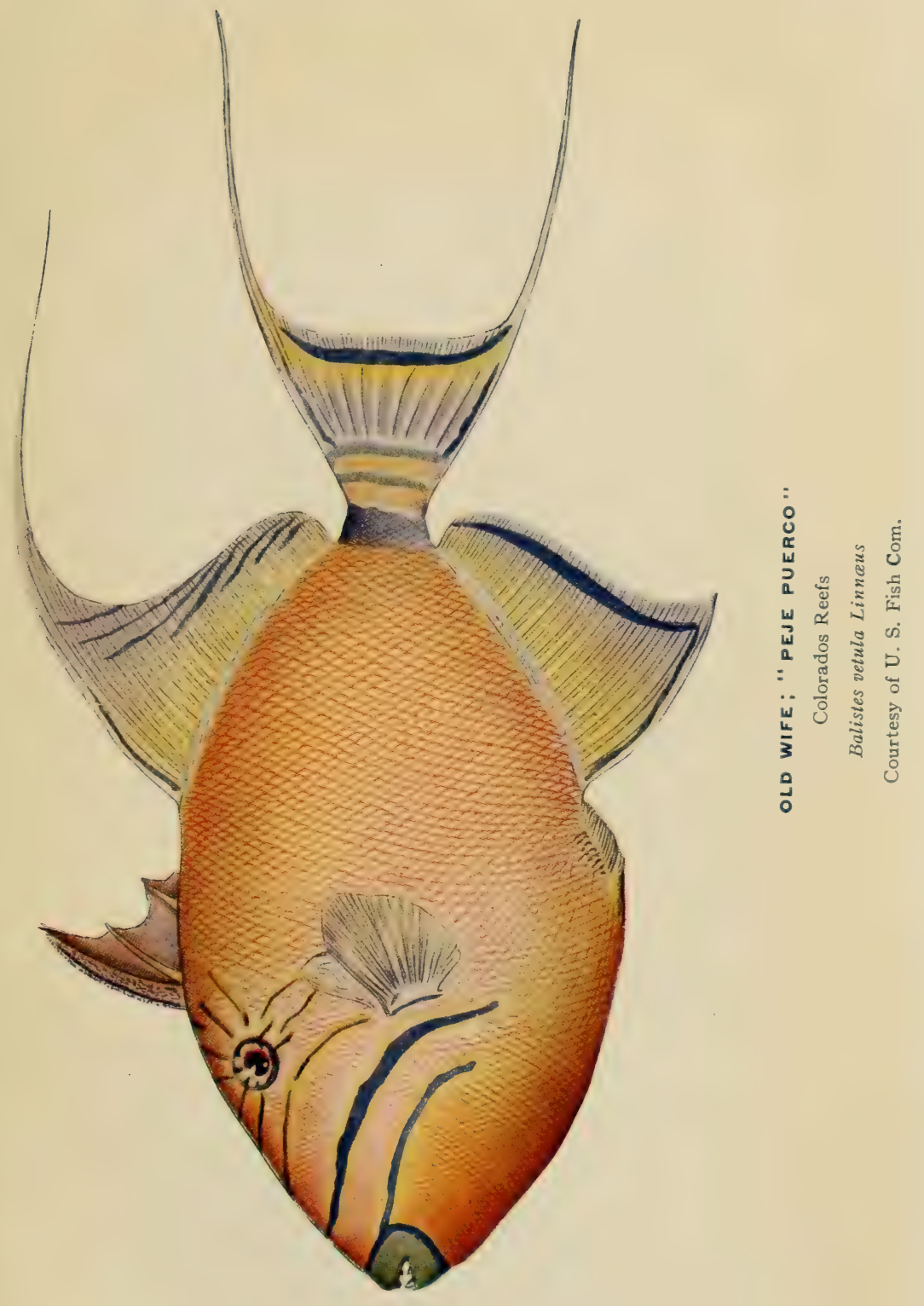



and a heavy lifeless atmosphere forbode more than the usual downpour. We hastened to cross the streams along the way. The final climb of Matahambre and the steep descent on the north side to the mine was accomplished just in time. The very heavens opened as we entered the office building and received a second welcome by Mr. Morse and the mine officials.

The Matahambre mine represents one of the few successful attempts in western Cuba to extract copper ore in paying quantities from the sandstones of the lomas. The copper deposits of this region occur in faults and are clearly intrusions through the several fault channels which interrupt the stratas of sandstones, shales, and slate composing these hills. Mineralization has taken place on both sides of the central east and west axis of the province, but it is principally on the northern side that ore in workable quantity has been found. Along certain fairly well-defined channels, considerable iron ore also occurs as a residual or mantle deposit. According to Mr. Morse-who has made a close study of the subject-there have been in this region three distinct movements which fractured and shattered the sedimentaries. 
The first faulting opened up the formation and resulted in a slight mineralization through the deeplying serpentines below. The second movement refractured and fissured the formation, and at that time the heavy mineralization occurred. The third reopened, fractured, and further faulted the strata and permitted of a renewed enrichment of mineral. These various movements which opened fissures through which the mineral welled up and replaced the sandstones and impregnated the adjacent strata with copper salts, have left a very complicated series of faults for the mining engineer to contend with. His first problem is to chart the slips and vertical changes. Mr. Morse conducted us through the main tunnel pointing out the fault evidences and demonstrating how a disappearing ore-bed can be relocated, without the hazard of guesswork. Typical analyses of the mixed sulphide copper ores from the mine show:

$\begin{array}{lrlr}\text { Copper } & 23.39 & \text { Magnesia } & .91 \\ \text { Silica } & 36.55 & \text { Arsenic } & .02 \\ \text { Iron } & \mathbf{1 3 . 0 4} & \text { Silver } & \mathbf{1 . 8 0} \\ \text { Aluminum } & 7.35 & \text { Gold } & .02 \\ \text { Water } & 7.80 & \text { Lime } & \text { trace } \\ \text { Sulphur } & 7.89 & & \end{array}$


The actual output of the mine and profits accruing, for obvious reasons, are withheld, but it is no breach of confidence to say that the mine has paid handsomely and has already netted its owners a substantial fortune.

The area of mineral deposits is within a strip extending from the Havana province line west about one hundred miles-and in width from the north face of the sierra to the coast-an average of ten miles. Throughout this area of high sandstone hills, copper intrusions as at Matahambre, are more or less in evidence and no doubt other rich discoveries will be made. Transportation to the cost and harbor facilities are serious considerations in this region.

The return trip to the coast was made in an ore wagon and without incident. As we neared the coastal strip of swamp we encountered almost our entire ship's company who were enjoying a ramble ashore. They had collected many lizards and with their guns looked like a lot of pirates on mischief bent. To this accusation they replied with equal force that we gave an excellent imitation of a company of bandits, so honors were even. They climbed into our ore wagon and all sang and 
shouted in the exuberance of health and high spirits. So disreputable a looking lot of merrymakers were no doubt eyed suspiciously by the few natives about the landing sheds of Santa Lucia and they probably felt relieved when we departed for our ship a mile or more away.

We had had a better opportunity upon this Azucar trip to observe the geological features of the country than had heretofore been presented to us. The general features here are altogether the same as evidenced in a cross-section about the longitude of Viñales. This consists, as heretofore observed, of a central high range of precipitous limestone sierras, with occasional detached outlying mogotes, and flanked on both sides north and south by a wide belt of less elevated rounded hills of sandstone and shales. The strata in both are usually tilted out of the horizontal, dipping northerly on the north side and southerly on the south, the high limestone sierras of the center making what would appear to be an anticline along its east and west axis. The even trend of the lines is often distorted and partially obliterated, and the continuity of the strata, as already noted, interrupted by faults. The sierra limestone some- 
times is metamorphosed into various grades of marble and in some localities well-preserved Ammonites are found. In the highly altered and disturbed sandstones and the more compact shales of the lomas no fossils have as yet been discovered. On the outer edges of the sandstones-to the north and south-are occasionally found much denuded patches of overlying Tertiary limestone. In the deeper valleys among the lomas evidences of an underlying serpentine may be detected,- the basic foundation of the island upon which all the sedimentaries have been laid.

If the sandstones of the lomas can be accepted as belonging to a later horizon than the limestone of the sierras, a simple solution of the geologic structure of the region is at once suggested. Taking the limestones to be of secondary age-probably Jurassic-as indicated by the Ammonites, we may imagine a horizontal strata of it of considerable thickness resting upon the serpentine core of the island and overlaid in the Cretaceous by the sands and clays of the present lomas. Before, or at the beginning of the Tertiary, a warping or folding of the strata along the axis of the Organos Mountains produced the wavelike conditions of strata shown 
opposite. The softer sandstone resting upon the sides of the folded limestone below, yielding more rapidly to denudation and gradually receding from the sierras, finally left them exposed and to weather down in their own peculiar fashion of fantastic castellated peaks and vertical walls. The sandstones, on the other hand, have been eroded more evenly into smooth rounded hills without particular alignment or system. Subsequent subsidence and elevation would account for the occasional Tertiary deposits and the Pleistocene coral rock fringes.

The absolute correctness of this explanation can only be confirmed by the determination of several facts-as yet unknown. One would be the finding of limestone of the sierra series below by borings through the sandstone, or by the discovery of a point of actual contact of the two series, or, finally, by discovery of fossil remains in the sandstone to determine its age.

As a contribution to the theory of overlying sandstones, Mr. Morse cited the lack of calcite about the ore beds lying within the sandstone. As these ore beds are intrusions from below forced up in acid solution through the fault channels, the presence of calcites scattered about the shales 

would be an almost certain result, had an overlying strata of limestone existed. This is, of course, negative evidence, but nevertheless carries weight.

An objection (also negative) to the hypothesis of overlying, and therefore more recent, sandstone, is in failure to find any examples of strata in situ showing such relative positions. Surely, it might be urged, somewhere in this area of denuded sandstones there must remain some trace of an underlying limestone.

In all other parts of Cuba, limestone, wherever occurring, is clearly superimposed upon all other rocks and not infrequently only caps the highest hills. Thus we were inclined to view the situation in Pinar del Rio with an a priori theory that the sierra limestone must be more recent than the heavy flanking of sandstones and shales. Until a careful recognizance by some trained geologist is made, no positive conclusions need be accepted as to the relative ages of the two systems, but in the light of present observation it seems certain that the Organ mountain limestone underlies the sandstone and that its present dominance above the other along a central axis is due first to folding and then to the more rapid weathering of the softer sandstone. 


\section{CHAPTER VIII}

\section{Santa Lucia to Dimas}

Sunday, May I7th. With the return of the Azucar party, we resumed our westward journey toward Cape San Antonio. The morning opened with cloudless sky and gentle east wind. At 7 o'clock the air temperature was $78^{\circ}$ and the water $82^{\circ}$. Our morning plunge precipitated the usual discussion anent the dangers of sea bathing, but on this particular occasion the debate was exceptionally violent, for Lesmes happened to recall an especially gruesome shark episode. We narrowly escaped a general massacre.

Bartsch, Torre, Clapp, and Rodriguez proceeded in the launch to take photographs of the Lucia bird colonies, while the schooner was put under way, and made out through a pass in the reef to blue water beyond-the inside passage between the reef and Cayo Hutia being too shallow for the Barrera. The open sea without was calm; the most sensitive being spared any doubts. 
Landsmen at sea would surely hail a remedy for mal de mer, accomplishing its end without paralyzing the nerve reflexes. Seasickness is a nervous disorder that may be likened to an acute prostration, nausea being merely a resultant secondary symptom. Medical treatment would seem to call for a doping of the nerves. As sensible people object to "dopes," the remedy is not desirable. It is a duty of our nerve centers to warn and protect us from danger. In an abnormal unstable condition of equilibrium these telegraphic messengers, with danger alarms ringing and unheeded, become wild and crazed, and the entire system of delicate adjustments goes awry. By a forced reasoning process our dutiful nerve centers may sometimes be made to accept the unaccustomed motions as both safe and agreeable and they become reconciled. This satisfactory subconsciousness may be brought about, by imagining oneself pleasantly swaying in a swing or dancing some pirouette. To combat the unsteady movements but adds to the nervous panic.

As the sea was smooth and the water perfectly clear we were here given an excellent opportunity to study the reef while slowly crossing it. That 
the reef is a very flourishing one and occupies the outermost edge only of the island shelf is altogether certain. The gradient of depth without the reef is exceedingly steep, the dark blue of ocean depths being entered at once upon crossing the barrier. For lack of proper apparatus for obtaining bottom samples from the deeper water without the reef we were unable to determine whether or not a line of dead reef exists on the slope without. From other indications, however, we were of the opinion that the platform (the island shelf) is of fairly recent submergence to about its present depth and that the present living reef is too young to have expanded very far in a seaward direction. The coral polyps find here almost ideal conditions for growth,-shallow water, high temperature, and a steady current, richly laden with food sweeping the edge of the shelf. No rivers with burden of silt interfere and the water is of exceptional purity.

Along a rising coast successive lines of fringing reef with occasional inner patches of dying coral might be expected, the outer ones being in the most flourishing condition. The Colorados, however, present but a single line of almost continuous living reef without the inner patches of living 
young coral which would find suitable conditions on a gradually deepening shelf. There are apparently no young inner reefs to menace navigation within the outer barrier. A further evidence of present stability of the platform and the youth of the reef is furnished by the complete lack of coral islands along the main line of the reef. Practically nowhere is the reef exposed save in a few spots where an exceptionally heavy sea might uncover a menacing tooth.

The bird-photographing party overtook the schooner while off Cape Hutia, the light draft launch permitting a short cut directly across the reef. Failing wind obliged us to tow for a time, but soon the northeast trade sprung up and we bowled along at excellent speed. The sensation of sailing in a heavy schooner is very agreeable. Accustomed only to engine-propelled craft, we enjoyed, as a real luxury, the steady gliding motion, silent save for the swish of water at the bow and the straining of cordage. When all goes well with favorable wind and tide one can idealize in poetic measure the sailing craft, but with a failing wind one is inclined, like King Richard, to offer much for horse-power. 
At two o'clock we anchored in the harbor of Dimas, which, like all the "harbors" along this portion of the coast, is no harbor at all. A dredging party immediately started out in the launch. Lesmes gathered his fish-traps and put forth in the auxiliary to set them. Torre, Simpson, and Rodriguez proceeded ashore to look for Cerion and to induce the natives to capture for us a specimen or two of the little crow (Corvus minor Gundl.) that lives here within a remarkably restricted range.

A final assault upon a stretch of shore line presenting an elevated bank-the first so far seen -netted us some snakes and lizards, a few crustaceans, jelly-fish, anemones, and some mollusks. There were no Cerions and our little crow eluded capture.

Up to the present we were not wholly satisfied with our marine collecting. The uniformity of the soft bottom and the generally swampy character of the shore had not given us the variety of conditions we hoped to meet. Assurances of our crew that more favorable conditions would be encountered farther west made us impatient to get on.

Some wandering chubascos threatened us in the 
late afternoon, but finally resolved themselves into a sunset of marvelous splendor. We turned in at dark to be prepared for an early start the next morning. 


\section{CHAPTER IX}

\section{To Santa Rosia and Santa Maria}

Monday, May I8th. At seven we were on our way with Santa Maria or the Estero de los Camarones as the objective point, for there fresh water of fair quality is obtainable from a river. Reckless extravagance had depleted our supply more quickly than expected, and the necessity for replenishing our casks was brought home to anyone daring to ask the cook-the guardian of the tanks -for a basin of water.

Little wind permitted but slow progress, so a dredging party took to the launch for a series of hauls near the reef in four to five fathoms, on soft weedy bottom. In somewhat shoaler water, another line of dredgings on harder sandy bottom of sponge and broken shell yielded the best returns so far with the dredge. Many Pecten were secured which flitted about in a tub of sea water on deck, by spasmodic opening and shutting of their shells. 
These lively bivalves, like Lima and some allied genera, possess a row of eyes upon their mantle edges which, although not likely capable of clear focused vision, nevertheless are extremely sensitive to light stimuli. A passing shadow causes every scallop instantly to close his shell, and any attempt to seize one sets him darting about with surprising quickness. Rapidity of movement and ability to elude enemies is not in itself remarkable even in quite low orders of life, but it is so in Pecten, because they belong to a group of animals (Pelecyopda) comprising many genera and thousands of species of slow-moving creatures rarely possessing traces of specialized visual organs. If this apparent freakishness of nature were carried out to the same degree among the higher orders of animals, we would be justified in expecting species of mammals with undeveloped sense organs, or races of men with one eye centrally placed, or possibly a row of eyes up and down the spinal column or on the ends of the fingers. In the lower orders specialized organs seem to be easily attained or lost according to their use or necessity in the vital economy of the species. One is forced to the conclusion that all specialized 
organs of the senses, of digestion, of the circulation, or any particular function, are in a sense merely luxuries and extra gifts, for they are not fundamental necessities of life. Countless millions of creatures, possessing none of these perfected organs of special purpose, live in our world, fight their battles, propagate their species, and survive, while numerous higher orders, possessing many, have failed in the life struggle. It seems clear that the possession of any perfected special organ imposes at once a dependence upon it which increases as the organ develops. A blind scallop would have small chance, while his near relative the lowly oyster, who has no eyes at all, gets on perfectly well.

We took here also some specimens of that extraordinary looking fish called the "toro" or "cow-fish" (Lactophrys tricornis). As these peculiar "trunk-fish" (of several species) are very abundant and well known they have been figured and described in many books. Their remarkable feature is a bony carapace that almost completely envelops the animal and through which project the tail and fins, the mouth and eyes. Only these parts are movable, otherwise the body is 
rigid. The shape is also very bizarre. We found them about rotting sponges, mangrove roots, and in weedy bottom.

The feature of the morning's dredging was a specimen belonging to an aberrant group of polychæte worms of unsuspected presence in these waters.

About II o'clock very threatening weather with violent wind squalls compelled the dredging party in the launch to overtake the schooner, a difficult task for the little craft that made a bad mess of it in the increasing chop, while the schooner with straining sails and following sea "carried a bone in her teeth." Arrived at the Estero the crew entered upon the laborious task of watering. All the big wine carboys stowed below were piled aboard the auxiliary and filled from the sluggish river that drained a swamp. We regarded with suspicion this dark beery looking water, but it proved to be excellent. Bad weather throughout the afternoon interfered with further collecting operations and with the preparation, as well, of previously taken material. However, some dredging was accomplished, and a later afternoon expedition to the shore netted us some especially fine 
Medusæ and Actinians which were successfully expanded in the magnesia bath. Among the trophies of the day were some exceedingly beautiful Eolids of pure white, with edges painted in brilliant yellow. These nudibranch mollusks are the veritable butterflies of the sea. Their colors are startlingly vivid and their schemes of decoration often fantastic and wonderful. This extensive group of beautiful creatures inhabiting all seas, of infinite variety and of superlative interest, offer a most inviting field for investigation. Many genera and species have been described and illustrated in color plates, but every day's collecting in favorable stations brings to hand specimens that defy identification and are more beautiful than any yet pictured in books. It takes a practiced eye to detect them in the mess of rubbish dumped from the dredge, for when disturbed these delicate creatures contract into shapeless little masses that appear to be of no importance and are allowed to fall into the discard. When placed, however, in a jar of clear sea water and permitted to rest for a time undisturbed, these little lumps of nothingness gradually unfold into exquisite beings. For purposes of preservation, the beauty of our nudibranch 
is like the loveliness of the orchid,-evanescent and fleeting. Unless killed and expanded with greatest care the graceful body shrinks into shapeless distortion in alcohol or formalin and even at best the glorious colors soon fade. The poor little creature, bereft of its soul of beauty, presents a pitiful object for study when finally placed in its graveyard of bottles upon some museum shelf.

It seems useless, however, to comment upon the beauty of any one particular object of nature that happens to fall into our nets. That which we consider beautiful is the approximation of some form or color accepted in our narrow range of observation as pleasing. The truth is that all living things possess a beauty that is almost perfection, our own personal judgment being a matter of education. The dullest hued and most inconspicuous creatures when studied are transformed into objects of superlative beauty. Even the despised cockroach and the common edible crab of Long Island Sound are perfect creatures in their own way and wonderfully beautiful. We have a natural abhorrence for worms, because we instinctively dislike anything that progresses in an undulatory motion. It suggests snakes, and snakes 
suggest poison, and poison suggests death. For such remote reasons, therefore, a worm is taboo, and from a conventional and probably even an inherited point of view, ugly and repellent, but no phylum of the animal kingdom can offer a more astounding array of beautiful creatures than does the Annulata.

The submarine light brought us a particularly fine catch at night. 


\section{CHAPTER $\mathrm{X}$}

\section{Santa Maria to Los Arroyos}

Tuesday, May Igth. An early morning visit to the river for water (the third expedition for the purpose) sufficed to fill our casks, while a field party made a collecting tour farther up the river, returning quite exhausted by the intense heat of the swamp.

A desperate effort was made this morning to put the cabin in order. Its confusion was twice confounded by the quantity of damp clothes that had accumulated. Every member of the expedition by this time had become more or less aquatic. We entered the water for collecting purposes whenever necessary and usually without bothering to remove clothes. The rigging of the schooner was always festooned with articles of raiment which, because of saturation with salt water, never would thoroughly dry. The coming of the afternoon rains precipitated hurried raids upon the rigging to rescue the garments for storage below, and the 
result was a hopeless confusion of trousers, shirts, underwear, and shoes on the cabin floor. Collecting parties returning to the schooner would strip off their meet clothes on deck and then hasten below to overhaul the junk pile for something to wear. Those fine discriminations between meum and tuum, supposed to characterize civilized man, became dulled, and the search for clothes was not so much for one's individual and particular garments as for any garments that seemed reasonably dry and of approximate fit. Thus there were many good-natured accusations of theft. "Some infamous scoundrel has stolen my only dry shirt" was a frequent complaint of the late arrival, and our crew was always vastly amused by our arraignments of each other upon such serious charges. Whenever, under dire necessity, one had to tap his trunk for a fresh article of clean, well-laundered linen, avarice shown in every eye and little plots were hatched.

We had by this time seen enough of the coast to form some definite idea of its configuration and the reasons therefor, and we had had ample opportunity to study the island-shelf over which we had been sailing day by day. The rough sketch opposite, 

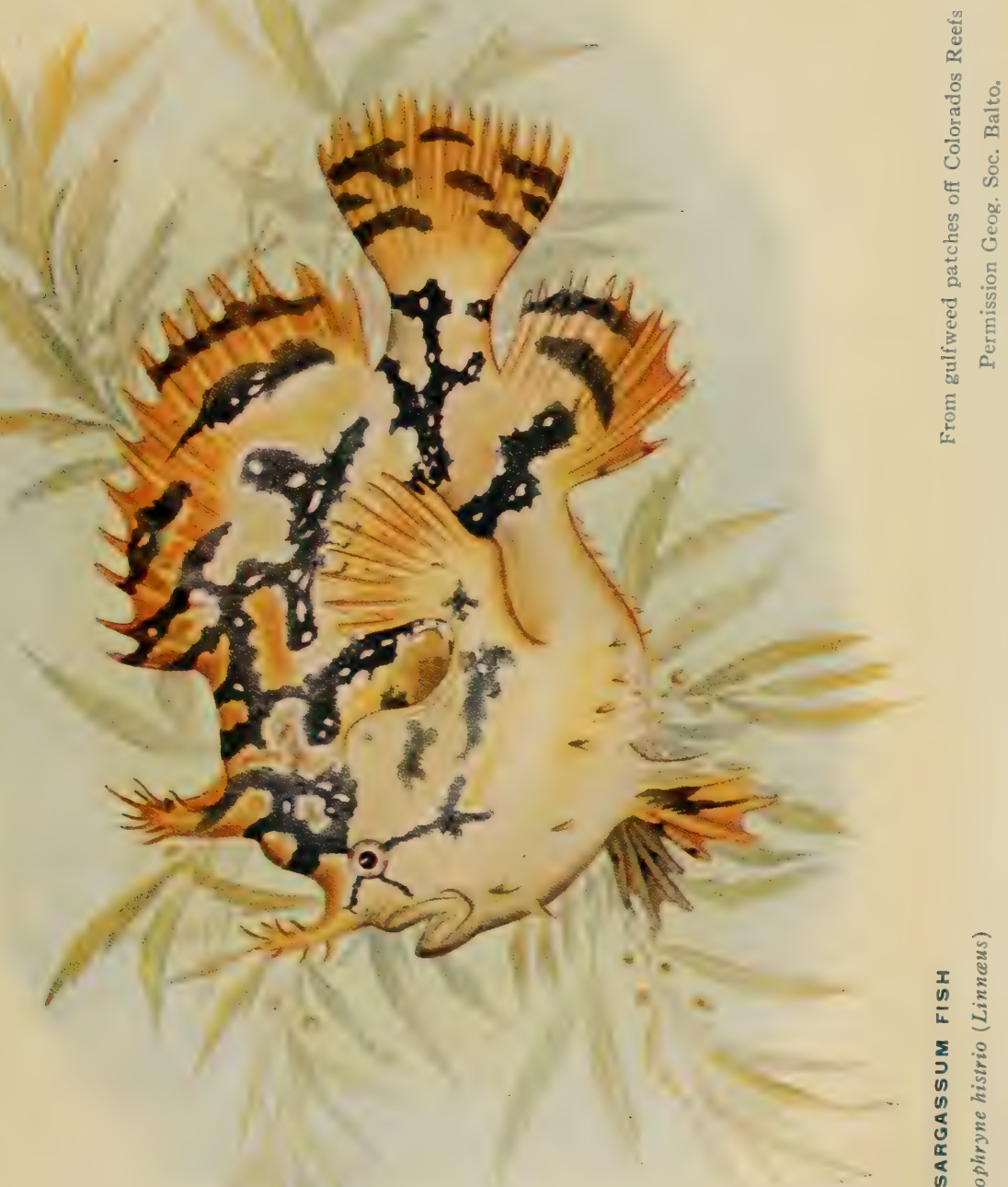

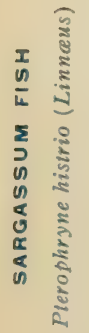



though not an actual map of any particular spot, shows in a simplified form the physical conditions of the shore line and of the submerged plateau, which are repeated continuously over a hundred miles from Cape Gobernadora to the Bay of Guadiana. West of this latter point (to Cape San Antonio) conditions are materially different.

From the base of the pine-covered hills, usually two or three miles inland, the coastal strip is composed of soils brought down by innumerable small rivers, the topography showing a gentle gradient shorn of all conspicuous elevations. A relatively slight sinking of the coast in very recent time has flooded the shore strip giving an indefinite shore-line of swampy character. At intervals of two or three miles are islands of mainland formation disposed at about right angles to the general trend of the shore. These islands represent the scant remains of low elevations between the eroded river valleys now "awash" and covered by a rather dense growth of mangrove. Some of these islands have a core of solid land. Tidal passages have been cut through some of them, and their separation from the mainland is not always positive. 
Between the outer ends of the islands and the coral reefs, a distance varying from one to five miles, is a comparatively open water-way-the "fairway." Through the fairway the alternating tides sweep east and west, keeping the channels scoured out, save for occasional accumulations of coral detritus and sand in eddy spots where sandbars, partially exposed, have formed by process of tidal action. These little outer islands, surrounded by elongated east and west bars, are composed of coarse hard-packed sand, broken fragments of coral, and vast quantities of broken shells, and are generally devoid of vegetation. Within and through the surrounding sand flats are numerous deep channels with steep banks cut by supplemental tidal action. The depth of these passages is about the same as the floor of the fairway. It is, of course, obvious that these sand islands, which usually lie just within the reef, have nothing whatever in common with the mangrove islands already referred to. Their formation in all cases is likely due to some original coral obstructions on the bottom which offered a trap for the tide-swept detritus of the reef and which were further aided by the fact that they happened 

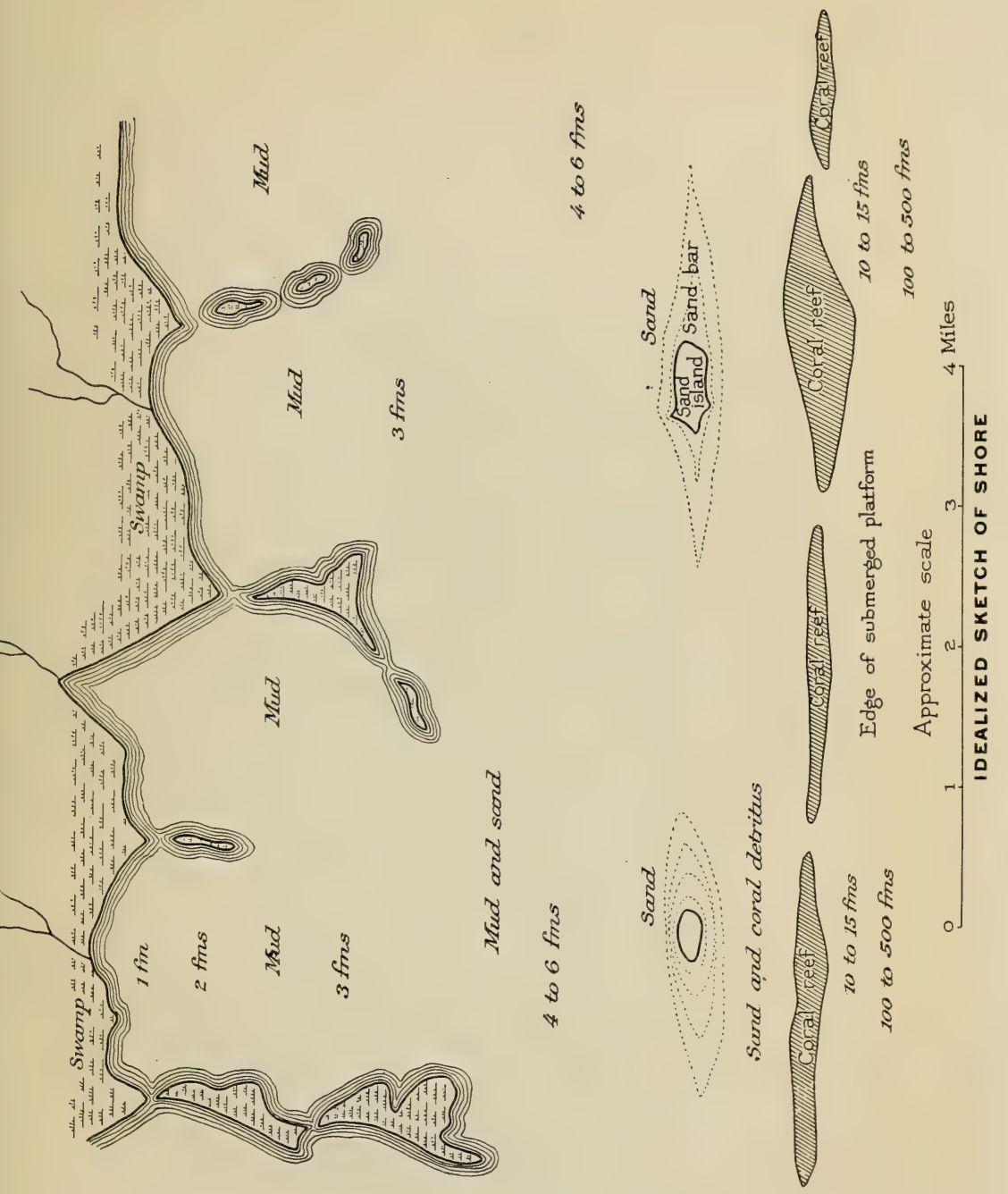

to be eddy spots, or areas where the currents meet and, becoming confused, release their cargoes of sand and other material derived from the nearby reef. The configuration of the bars is invariably lengthwise with the direction of the current, and attenuate at both ends. The very small part of the bars usually exposed are gradually building up by wave action. These bars now form the chief obstruction to navigation by larger vessels of the reef-enclosed waters.

Between the mangrove islands projecting out from the shore at intervals of two or three miles the depth of the intervening bays is very uniform, shelving gently from shore to about four fathoms, mud and sand bottom. In the area between the ends of the mangrove islands and the reef the normal depth increases to five or six fathoms and is uniform and continuous save for the occasional interruption of the fairway by the sand flats and bars already described. The bottom within this area is more diversified, but is usually a mixture of coarser sand and finer mud in varying proportions. The bottom, in general, even close to the shore beaches, seems to be composed far more of material derived from the reef than it is of sediments from 
the land. Whatever silts are brought down by the small and unimportant rivers appear to be caught by the shore swamps through which the rivers sluggishly meander before reaching the sea. Over all the bottom there are evidences of deposit of a certain amount of oolitic mud resulting from the activities of the denitrifying bacteria that release the calcium in sea-water solution into infinitely fine particles calcium-carbonate. The amount here of this oolitic "mush" is exceedingly small as compared with the vast areas covered by it in southern Florida and the Bahamas.

Over much of the bottom is a growth of Thalassa and other grasses and weeds, especially within the bays. In the fairway are extensive areas of clean sand-bottom interspersed with patches of marine vegetation. Except within a belt adjacent to the reef there are but few gardens of sponge and gorgonians.

The last feature of the region, as already noted, is the reef itself on the outer edge of the island shelf. It varies in width from a few yards to a half-mile, and its continuity is broken by numerous channels across. Some of these afford ample way for entrance of vessels of ordinary draft. 
The presence of the Gulf Stream, which impinges upon the reefs, together with the high temperature of the water within the outer barrier $\left(82^{\circ}\right.$ to $84^{\circ}$ in May and June), would justify belief that a great wealth of marine life must here exist. Our expectations in this respect were not fully realized, a lack of diversity of bottom conditions probably accounting for it. It is hardly correct to speak of a paucity of life within the area described, but better of a lack of diversity of animal groups that a wider range of stations would certainly provide. Throughout the entire length of this section of coast, there is no trace of shore limestone; none of the Tertiary beds of the east, nor of the elevated Pleistocene reefs of Cape San Antonio.

About noon, while proceeding toward Arroyos, we sighted, just off our course, a large sand flat with about a half-acre exposed. We dropped anchor fifty yards from the little island and all put ashore with collecting equipment. This sand flat presented an exceptionally fine opportunity for study of such character of station, and we made a very thorough exploration of it. Owing to the shifting nature of the sands the flats seemed to be 
very bare of life, excepting for the many whitespined sea-urchins, some large stars, and a few holothurians. All of these creatures, especially the latter, were busily at work triturating the coarse sand by digestive action. They eat the sand for the organic matter it contains subjecting it to a grinding process. The amount of coarse sand thus quickly reduced to finer particles is far greater than one would at first suppose. No doubt the feeding habits of these echinoderms constitute an important factor in the breaking-down process of reef from massive rock to fine mud. Eddy rows of dead shells along the edges of the channels gave us a fair index to the molluscan species existing a little farther out on the reef, although they afforded but few good cabinet specimens. The excellent taste shown by the short-spined seaurchins in the selection of shells for their protective armament aided us very greatly, and the choicest specimens were obtained by robbing the urchins of them. Standing upon the edge of the deep channels and basins in the flats, we could see with the aid of our water-glasses quantities of large fish that swam lazily about their clear limpid depths. These fish were not the usual reef species, 
but those more eagerly sought by the fishermen for the Havana markets.

Our Patron again distinguished himself by his aquatic accomplishments. A large shark appeared in the shallow water, and those near by decided to capture him. The launch was brought around; the Patron, poised on the bow with the grains, watched for an opportunity to strike. The rapid little launch with throttle wide open dashed about like a polo pony following the ball. When the right moment came, the Patron did not merely hurl the spear, as might have been expected, but threw himself with it upon the shark in order that his weight would drive home the sharp points. Fortunately for the big fish, the grains bent double on his back and he escaped amid a great splashing and swirling of water, in the midst of which floundered the Patron. Soon after, we had more excitement in an attempt to capture a huge skate that flapped his way over the shoals. I am sure we all felt relieved that our prey had escaped. As we could have done nothing with either shark or skate had we caught them, our attack upon them can only be attributed to a flare-up of our savage natures-an assault with intent to kill for the pleas- 
ure of killing. There is nothing more distressing than the wanton wish to destroy life. This desire amounts almost to an instinct and is a surviving impulse from our carnivorous ancestors of the cave-dwelling era. In thoughtless and heedless manner and under the elastic term of "sport" we have exterminated many harmless birds and animals, and now with the opening of Africa we are destroying the last survivors of the big mammals. If our civilized women who treat their pets and domestic animals with lavish kindness could only realize the cruelties of the plume hunter and the fur trappers of the north, they would surely find substitutes for the feathers in their hats and the fur for their garments. Much has been written of the egrets and other birds that now approach extermination through the wholesale slaughter inspired by human vanity, and happily there has been found enough humane feeling to check it. Less, however, is known of the suffering of the fur-bearing animals of the north, that perish miserably in the steel traps, if they fail to gnaw off the imprisoned foot that is lacerated in its steel jaws. A feeling of comradeship with all living creatures of the forests meets a response with 
many a resultant pleasure. It brings happiness of a higher quality than can the momentary satisfaction of a good shot at cost of a life. Life is a sacred thing. We do not know what it is; we cannot create it; it is the mystery of the universe. To wish to take it wantonly can only be explained on the hypothesis of a survival of primitive instincts. That this must be the case is demonstrated in the fact that a people, representing the highest type of civilization and who individually are the kindest men and women in the world, enjoy to the utmost the "sport" of slaughtering pheasants by the hundreds and thousands that have been raised for that special purpose.

With a strong breeze we continued our way, arriving at Los Arroyos about 6 P.M. and anchored off the steamer pier. Los Arroyos is a port of call of a coasting line of steamers from Havana and is a town of several hundred. As we needed alcohol and some few provisions, a shore party immediately landed. Our crew showed much interest in Arroyos, and all of them made preparations for a visit to the town. A vast amount of prinking and unlimbering of neckwear followed, and some of our crew we hardly recognized in their 
new apparel. The reason for all this hair brushing and cologne appeared later when we learned that Los Arroyos cherishes a tradition of pretty girls. The Patron, however, alleged that all good traditions of Los Arroyos were only myths. While on the subject, however, he did not mind telling us that he knew a place where the women were all beautiful and the men all brave, and that was his own blessed island of Majorca in the far-away Mediterranean Sea. 


\section{CHAPTER XI}

\section{Los Arroyos}

Wednesday, May 2oth. A combination of circumstances decided us to remain at Arroyos a full day. In the first place, May 2oth is a day of fiesta, and Dr. Torre was in demand as an orator to help out the festivities arranged by the loyal sons of Arroyos in celebration of this, the Cuban day of independence. The genial doctor, whom we called Don Carlos, appearing in his ceremonial garb of black, proceeded ashore in much state, to be met at the wharf by the Alcalde and a committee of distinguished citizens. Greenlaw had also announced that the engine of the launch had a distemper that required treatment. The electrical equipment from constant wetting leaked from every pore of its soggy insulation. We were overwhelmed with material collected that needed proper treatment and packing. And finally, a Havana steamer was due with mail.

By noon the last of the tagged parcels wrapped 
in cheesecloth were consigned to the alcohol tanks, the last bottles sealed, the remaining snakes, lizards, and fish were injected with formalin and stowed away. The actinians and medusæ from the Estero, having received their bath of magnesium sulphate and cocaine, started on their progressive course through the various alcohols. The last of the material from the Azucar expedition was finally disposed of, and the satisfaction of having caught up with our work rested joyfully upon us. Only Gill with his paints and brushes toiled on, for his task was, in the very nature of things, never-ending. What a luxury it would be upon a collecting expedition to have along a corps of well-trained preparators to do nothing but look after the catch! With collectors constantly at work, the material multiplies very rapidly and for satisfactory results the specimens require immediate attention when brought aboard. Half the value of a catch depends upon quick and skillful treatment, while many groups of marine creatures brought in are lost if not put through an immediate process of killing, expanding, and final baths in alcohol. The field parties usually return to the ship tired, longing 
for dry clothes, rest, supper, and bed, and sometimes they are ready for bed without the preliminaries.

About noon, the Havana steamer, the Antolin Collado, an ancient side-wheeler, flapped into port, but alas, brought us no mail.

Vicious-looking chubascos gathered about shortly after midday, and a hot moisture-laden wind sapped our energies already depleted by the long morning's work. Later, the wind shifted to a land breeze blowing cool and fragrant with the scent of trees and bearing to us strains of the curious Cuban music that was probably a part of the day's merrymaking in Arroyos. The effect of a drop in temperature was like wine. Everyone pulled himself together and found something to do. The chickens in the coops forward ceased drooping; Simpson began to pace the deck impatient to get busy, and making uncomplimentary remarks about the Spanish-American weakness for fiestas. Lesmes awoke and began repairing his traps. Unable to stand further inaction under the stimulus of the cooler air, a dredging party went out in the launch, now restored, and made a series of very successful hauls in two to three fathoms, off 
Buena Vista Key. A shore-collecting party met with less success.

In the early evening Dr. Torre arrived on board. He was happy but hoarse, for he had made a number of speeches that "took" and had met with a very cordial reception. About dinner-time the versatile Don Carlos was busy forward superintending the making of pineapple ice, and thus in a way we all of us shared in the celebration of Cuba's independence. 


\section{CHAPTER XII}

\section{Los Arroyos to Punta Colorado}

Thursday, May 21st. Before starting again on our westward journey another landing had to be made for fresh provisions ordered the day before. At 9 o'clock we were under way with all supplemental sail set. The weather outlook was anything but encouraging. Great banks of stormclouds, forming over the sierras, gave forebodings of trouble, and puffy shifting winds warned us to be alert. The chubascos were getting more frequent and angry, while the steady northeast trades were being more and more interrupted by fickle winds. We were now very desirous of getting into the waters about the western extremity of Cuba, for there we believed would be encountered more varied conditions of bottom for the dredge. The extension of land from Guadiana Bay to Cape San Antonio we knew to be geologically different and we anticipated there better collecting conditions. Punta Colorado, 
until yesterday (geologically speaking), was the northwest extremity of Cuba. To the west of it extended for many miles a shallow sea covering the island shelf. Along the southern part of this shelf a wide coral reef was built. Then a Pleistocene elevation of about forty or fifty feet added this reef to the main island with Cape San Antonio marking the western terminus. This recently acquired territory, as might be expected, presents a very different aspect from that of the older country to the east. It is low and level but not the result of denudation, and on account of its limestone (reef) foundation is heavily forested.

As we closely passed Points Avalo and Pinatillo to avoid the shoals of extensive sand flats without, the storm-clouds that had obscured the receding sierras dissolved revealing for a time the north and south range already alluded to which, beginning in Peña Blanca on the north, traverses the island. This mountain system may be the result of a second warping that elevated the limestone mass along an axis at right angles to that of the Organos series. The range, from our present point of view, seemed to be continuous to a point about Guane near the southern coast where 
it is then broken into detached peaks of considerable height. The last points of land jutting out from the mainland-Capes Avalo, Pinatillo, and Colorado-differ from the series of projecting islands which we had been passing every day, only in that they are more elevated and consequently not merely mangrove patches. Upon them are some houses, but their trees (as along the entire coast from Esperanza) appeared to be either dead or greatly injured-probably the result of hurricanes. It was a relief to see white sand beaches replacing the monotonous mangrove littoral.

Through some misunderstanding of orders we overshot our mark at Punta Colorado and sailed on toward the land dimly discerned beyond-the beginning of the raised coral reef region already referred to, that terminates some forty or fifty miles farther west in Cape San Antonio. Where this new Pleistocene peninsula connects with the older mainland is a deep indentation in the coast called the Bay of Guadiana at the head of which is the little village of $\mathrm{LaFe}$. This is the last port of call for the coasting steamers plying west of Havana, and from it may be reached by a somewhat uncertain stage line the terminus of the railroad at Guane. 
Finding ourselves at Punta Tolete, west of Guadiana, we decided upon a prospecting shore raid. Our disappointment was great to find the shore a hopeless mangrove jungle with no trace of calcareous rock in sight. The exposed coralthe backbone of the land-was too far back from the swampy coast to have justified an attempt to reach it from this point, so we contented ourselves with making a number of dredge hauls. The species taken were largely different from those of any dredgings theretofore made.

We had special reasons for wishing to stop at Punta Colorado, as a reported sponge bed near the end of the point gave promise of some good collecting, and an American-owned fruit-farm on the cape offered opportunity to replenish our supply of oranges now about exhausted. Accordingly we put back, coaxing our way against a diminishing wind. It was too late to accomplish anything when we finally anchored in the open off the cape, but a shore party utilized the remaining hours of daylight for a preliminary survey of the beach.

The bottom hereabout seemed to be of hard sand and fairly paved with sea-urchins and stars. At night the submarine light brought us unusually 
good returns, a notable feature being a fine large species of Hippocampus - the "sea-horse."

At dinner that night we had an instructive conversation upon man's ability to accomplish wonderful feats of strength and agility when under the stimulus of great fear. The subject was introduced by a member of our crew who had acquired a good working knowledge of unnatural history through extensive reading of the Sunday supplements. His imagination, so nourished, peopled the earth and the waters beneath with many strange creatures, which, if captured, would necessitate a complete revision of zoölogical classifications. He recounted with perfect faith the exploit of a friend who, being capsized upon the reef, found himself surrounded by sharks. His efforts to gain a footing upon the sharp corals only resulted in cruel laceration of his feet and hands. In such predicament he was forced to mighty effort to save himself and he then and there accomplished what might seem, to one of limited experience, a very miraculous thing. He ran along the surface of the water for a hundred yards or more-to be exact, a trifle over an even hundred yards-to shore and safety. We were all stunned into silence. 
From the total of our combined experiences and reading we could recall no such defiance of the laws of gravity, save possibly the one of biblical reference which delicacy forbade mentioning. Then Dr. Torre forged to the front and saved us from a humiliating rout. With great solemnity he told of a friend of his own who had accomplished what might appear to the ignorant as a wholly impossible feat. Said friend merely in a mood of sportiveness was once running around a tree just to see how fast he could do it. His speed increased until he fairly seemed borne upon the wings of a cyclone. So great had become his momentum that he was unable to stop and danger became imminent lest the strain upon heart and brain would result fatally. Then it was that a great inspiration came to him, and like the man on the reef he also made a mighty effort. Reaching forward he actually seized himself around the waist and hanging on for dear life succeeded finally in dragging himself down. He certainly saved himself from an awful fate.

We turned in a little apprehensive, for our anchorage was exposed, the holding ground bad, and the weather very threatening. 


\section{CHAPTER XIII}

\section{Cape Colorado to Cape Cajon}

Friday, May 22d. Our anticipations of a bad night were fully realized. The wind howled dismally, creating an ugly chop. At daylight the Patron, Bartsch, Clapp, and Rodriguez, in the launch, followed a native fishing sloop bound for the flats to haul seines. By means of a "silver hook" they obtained fine specimens of the commoner species of fish taken in the sloop's nets. A few dredge hauls added but little to the morning's foray, the most notable acquisition being a slender smooth species of Dentalium, new to our collecting, and some spiny murices. The reported sponge bottom could not be located, the roughness of the water preventing any clear view of the bottom. The American fruit-farm, like the sponges, proved traditional, and our visions of golden fruit were dispelled. If there is such a farm it must be located far back in a better and greener land than Cape Colorado presents to the view. Possibly 
the cheerless dull sky lent some of its own gloom to the land below as dull skies everywhere are likely to do. We felt no desire to explore the country but rather to push on rapidly as possible to the "promised land" of Cape San Antonio. Anticipations of great success collecting about San Antonio had gradually taken on a rosy glow. Our fancies of the place were stimulated by repeated assurances of our crew, that there the particular marine conditions we sought would be found. At that point the majestic Gulf Stream sweeps in close to shore, while rocks and reefs abound and large tide pools harbor the very aristocracy of marine life. By degrees we even began to believe that there, beneath an everlasting sunshine, the waters were always calm and sparkling, with no rain to chill, no wind squalls to baffle, and no choppy waves to vex.

By Io o'clock we started upon our long run with every sail set. Our boats-the auxiliary, launch, and tender-trailed behind in single file. At first we made fine progress with a strong following wind bellying out the big try-sail, the small craft astern threatening each other in a race down followirg seas to overtake the schooner towing 
them. Having passed the entrance to Guadiana Bay we followed, about a mile out, the straight densely forested shore line of the low peninsula. Then the wind ceased and a fine drizzling rain set in. We performed various feats of necromancy to entice the wind, but by some error in the process we brought only puffs from the wrong direction. A succession of calms, hard squalls, and shifting light airs was meted out to us, and the fine rain never ceased. Only some attempts to dredge from the launch during the calm periods seemed an effective method of bringing wind from the right direction to our sails and then we would have to scramble aboard again, and the wind would at once disappear. Besides this, the launch engine had caught some new ailment from the damp air, that left it very weak. We gathered about it, felt its pulse, and inspected its tongue, but our solemn consultations took on the funereal aspect as of those administering the last sad obsequies to a dearly beloved engine. Let it be recorded that a high-tension jump-spark ignition system is not the best for exposure to rain and spray. A low-tension make-and-break outfit is more reliable under such conditions, and absolute 
reliability of the power plant is of first importance in navigating about coral reefs.

All, including the crew not on watch, finally settled down for an afternoon of quiet resignation. As many as could do so crowded into the cabin and lay about in various attitudes suggestive of discomfort or actual suffering. The floor of the cabin seemed to be an exceptionally hard one, but this evil could be mitigated somewhat by gathering together as many clothes as possible (not already appropriated by others) to form a thin mattress and by using the edge of a steamer trunk or suit case for a pillow. It remained always a question whether it were better to stay below where there was no air but it was dry, or go on deck where there was an abundance of air but it was wet. The solution of the problem seemed to be found in that the other place was the better, and a more or less continuous procession of the discontented crawled up and down the ladder to test out their theories on the subject.

About 3 P.M. the rain ceased and a fine east wind sprung up-the normal trade reasserting itself-and immediately life became worth while. The clearing skies revealed a water horizon back 
of us, the sierras now having dropped out of sight. On the horizon ahead, tops of trees, apparently far out to sea and raised high above the water by mirage effect, gradually developed into solid forest as we approached. The upright steel column of the wireless station at Cape San Antonio appeared indistinct above the forest. Finally the Cayos de la Leña, a group of small mangrove islands lying close into shore, were passed and just beyond them we anchored at 6.30 , about a halfmile from shore. Two or three miles beyond is Cape Cajon which, had we rounded it, would have placed us beyond and west of Cuba, for here the shore turns for a few miles to the south and then to the east "on its way back." About midway along this north and south stretch is the Lighthouse "Roncali" and this is Cape San Antonio. It would have been quite possible to round Cajon and take a position for the night off the light but our Patron advised against it. The currents there are strong, the holding very bad, and the position exposed to all but east winds. The pseudobasin formed by the Leña keys, the arching-in line of shore and the projecting Cape Cajon, offered a better haven with its partial shelter and 
good bottom for the anchor. Although a bad place in a norther, the chances of one are practically nil so late in the season.

At last we had arrived. In the failing light we distinguished limestone rock ashore-at one point quite clearly discernible. We would therefore make the Ensenada de Cajon our headquarters and use the launch and auxiliary to reach all other points of interest, to visit the light, and to explore the shores. The Patron warned us, however, that this was a veritable graveyard of ships and the place where all bad weather was manufactured.

We turned in early, eager for the morning to come and end our laborious inaction. 


\section{CHAPTER XIV}

\section{Cape San Antonio}

Saturday, May 23d. Daylight brought a perfect realization of our rosy day-dreams concerning the waters about Cape San Antonio. For the first time in a number of days the sun arose into a cloudless sky, and a fresh dry atmosphere presaged fine weather. The water about us was crystal clear. We could see the anchor chain winding along the bottom through the marine growths until lost by refraction twenty or thirty feet beyond. Lying in a cove near the shore were several large schooners loading sacks of charcoal for Havana. It was disappointing that the shores in sight were swampy and fringed with mangrove and buttonwood. In one spot, however, near a deserted house toward Cajon Point, was an indication of limestone rock. At the point of land nearest us, and opposite our anchorage, appeared a narrow opening into the forest with a rude dock; otherwise there seemed no break in the 
solid forest front, and the country appeared to be an uninhabited wilderness.

The Leña keys were obviously mangrove though probably built upon a core of coral rock. Looking north, over the open sea, no evidence of the coral reef, the Colorados, could be distinguished. From Antonio to Cape Colorado the reef lies far out, quite out of sight of land, and presents a grave menace to ships, being unmarked, unlighted, and uncharted. It is placed on the very edge of profoundly deep water and is swept by currents whose directions, force, and frequency are but vaguely known.

Torre, Clapp, Simpson, and Rodriguez elected to join forces in a shore party. They entered the woods through the little opening at the dock, finding there the terminus of a roughly laid narrow gauge track, used by the charcoal men to bring out their sacks of fuel from the interior forests. A mule-driven car was captured that had just discharged its cargo, and was about to return, and so the party enjoyed the luxury of a ride, which, however rough, was better than walking along the widely spaced ties. Traversing a swamp of about a mile, the party encountered the first solid rock, 


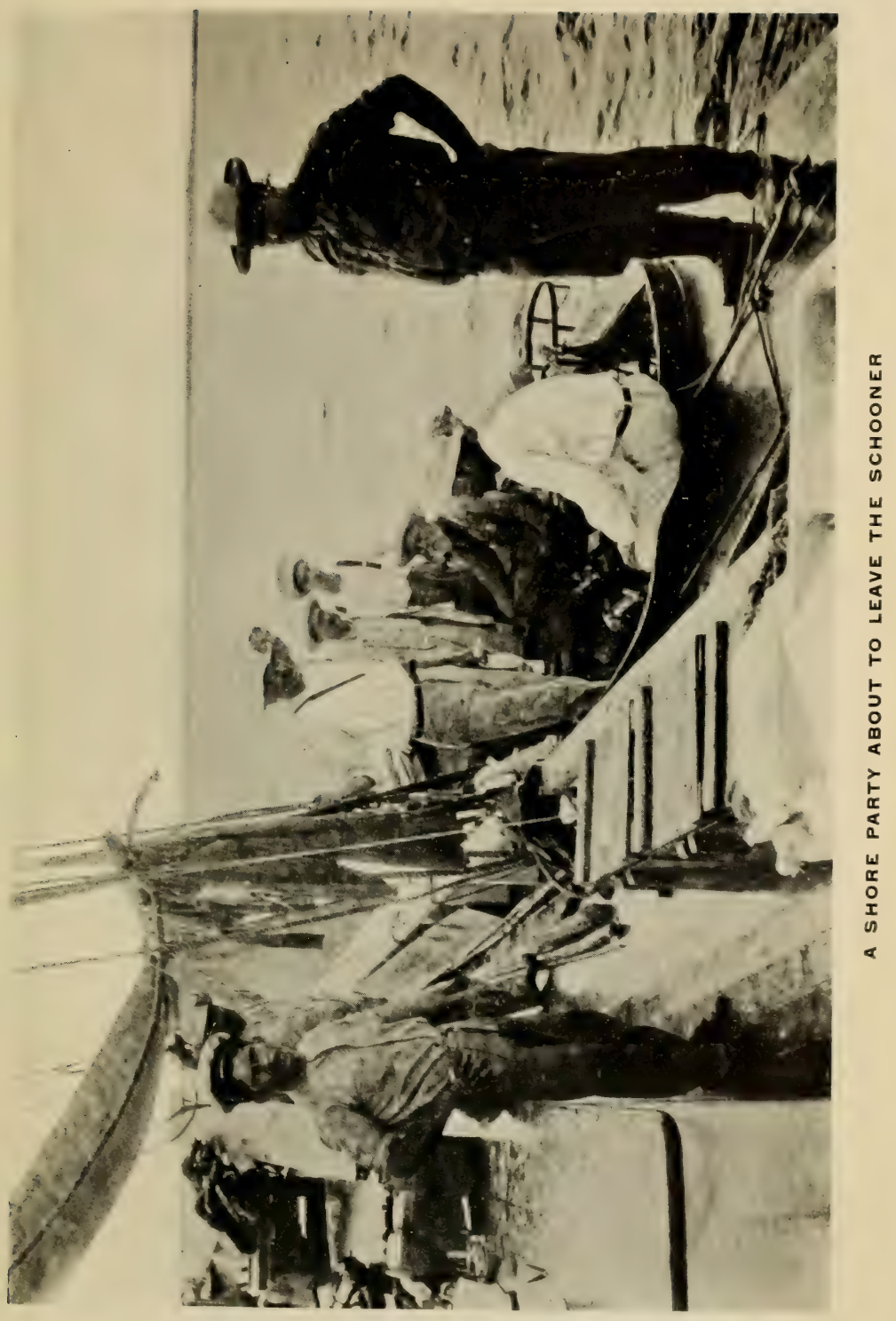



a reef-formed limestone, and there they began a search for land-shells.

Barring one or two species of Urocoptids taken by Charles Wright some fifty years ago at La Jaula, in the extreme eastern end of the peninsula, there are no records of land-shells from this entire region. It is, indeed, a terra incognita to the naturalist. As it differs in all physical characters from the sierra, or the pine loma region, it was reasonable to suppose that some discoveries of interest might result from our visit. This country is of a type that corresponds closely to the flat slightly elevated coastal strip found south of the Cienega de Zapatos and also in the south half of the Isle of Pines. Its forest character is quite the same and all the physical conditions of life are wholly similar. We believed that its fauna would prove to be generically similar but specifically distinct, at least among the land-shells, and such proved to be the case to a very large extent.

The shore party was obliged to combat clouds of mosquitoes that never ceased their ravenous attack from the moment they entered the woods. Continuing some three miles farther, collecting along the way, Clapp and Simpson abandoned the 
car in order to make a short cut of about two miles to attain the other-the Caribbean side of the peninsula. Here, to their great joy, the first Cerion were taken. Torre and Rodriguez continued in the car bound for the cape, eventually arriving at the lighthouse.

The return journey afoot of Clapp and Simpson through the hot forest and swamps was a heartbreaking experience. As this was intended for a preliminary skirmish to get the lay of the land, note the character of its vegetation and prospect for the best collecting stations, more time was spent by them in forging ahead to explore than in actually searching for specimens. However, the land-shells they did obtain were of great interest and specifically different from anything so far collected upon our expedition.

Having provisioned the launch for a day (the engine had revived under drier weather conditions) and with a great array of collecting paraphernalia, Bartsch, the Patron, and myself, with Greenlaw in charge, set out for adventure, prepared to follow wherever it might lead. We first inspected the Leña keys and made some hauls in the narrow deep passages between the islands where a bottom 
$\stackrel{\text { Current }}{\longrightarrow}$

$D^{e^{e p}}$ blew water

$\rightarrow$ Line of refs

Reef

Reef

Sand 5106 fms. Scattered coral patches

1

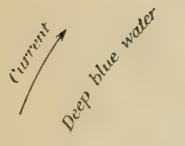

Reef

Sand $\rightleftarrows$ Tide currents

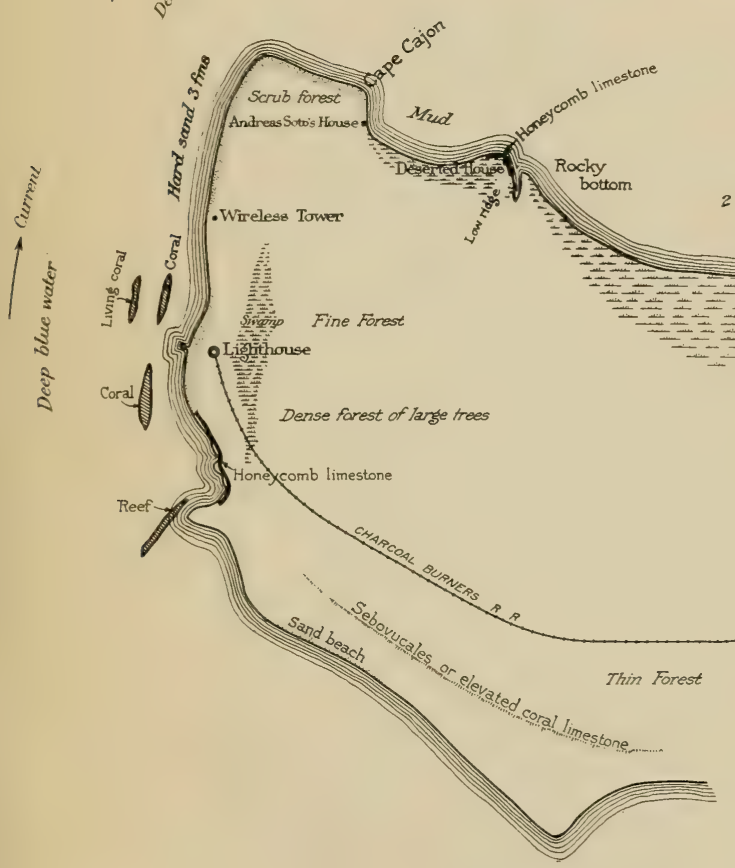

sand and mud 3 to 5 fins. 

of soft peaty character thinly overlays a flat rock foundation. Outside of a narrow belt of such vegetable deposit, immediately adjacent to the keys, the bottom takes on the character of a young reef growth, and through perfectly clear transparent water presents the fascinating "marine garden" aspect. There are occasional isolated coral heads of considerable size (Porites), about which hover many of those brilliantly colored little fish that seem always to be associated with such stations. These little sea children of the spectrum find security close to the sting rays of the actinians, and those that do not live about the coral heads and among the caves and holes of a reef follow closely under the shelter of floating medusæ, relying upon their poison filaments to protect them from their enemies. That the streamers of the Physalia, for instance, afford good protection there can be no doubt, for nearly every floating "Portuguese man-of-war" harbors a little colony of these commensal fish. Such a sea bottom as here found is a favored station for many sponges, the sea-fans, purple and yellow (Rhipidogorgia flabellum) and other gorgonians (G. acerosa, heptogorgia, virgulata, and Xiphigorgia anceps), Plexaura, hydroid colo- 
nies of large bushlike appearance, and the many little tree-like madrepores.

It was here we saw our first sponges; they were exceedingly abundant and large. Of the several species and their varieties that are sought for commercial purposes in Antillean and Floridian waters, I think we noted here about all, but I do not know that any sponge fishing has ever been regularly followed in this region. If not, it may be owing to lack of the only really valuable species -the "Sheepswool" (Spongia equina gossypina) in these waters. None of us were sufficiently expert to identify the different species merely by looking down at them through the eight or ten feet of water, for several of the sponges while growing on the bottom look much alike to the uninitiated. This would certainly seem to be an excellent field for prospecting on the part of the Key West spongers who are now hard driven to find fresher fields for their industry. One of the most usual as well as picturesque sights in Southern Florida and Bahaman waters is the fleet of spongers with their strings of diminutive little tenders trailing out behind their sloops, and in each tender the collection of long poles 
with hooks attached. We saw none of these in Cuba.

Again our Patron acquired merit by his wonderful aquatic accomplishments. Any interesting looking object on the bottom that we coveted, needed but to be indicated and he would dive, never failing to secure it for us. Once, after a long struggle, he wrenched loose from its moorings and brought to the surface a huge loggerhead sponge, weighing quite fifty pounds, his breast and arms smarting with its spicules. Thus thr? Patron obtained for us a fine lot of choice spec:mens of gorgonians, madrepores, algæ, etc. For the less obvious life of the "gardens" we had resort to the dredge, although such a bottom is not well adapted to this mode of collecting. Besides the difficulty of frequent fouling below, another trouble beset us each time the dredge was brought up. This was the usual presence in the net of the diadema sea-urchin (Centrochinus setosum). The long purple-black spines of this creature are sharp as needles and minutely sculptured with recurved hooks. They are brittle as spun glass so the effect of contact with them, however slight, is to break off in one's flesh glassy splinters which defy extraction. 
To make an "accident" still worse, these spines are more or less bedaubed with a slimy acrid substance which acts as a powerful irritant. From a slight wound on the hand one may suffer pain even to the shoulder and for some moments actually feel faint. While these spines may not be extracted, they do eventually absorb and disappear. One experience, however slight, with a diadema, is quite sufficient to inspire great respect for them ever after. During the hours of bright sunshine the diademas seek cover under the rocks and coral masses, and their presence is betrayed only by occasional tufts of their bristling bayonets that project here and there from beneath their hiding-places. In the late afternoon when the slanting rays of the sun illumine the reef bottom less brightly, they issue forth en masse in search of food and probably continue their slow wanderings throughout the night. In localities where hidingplaces are few, such as upon sandy patches in or near a reef, the diademas are always more or less in evidence. No protective covering-short of a steel armor-would offer any real security. Constant vigilance and care, when entering their domain, is the only safeguard. 


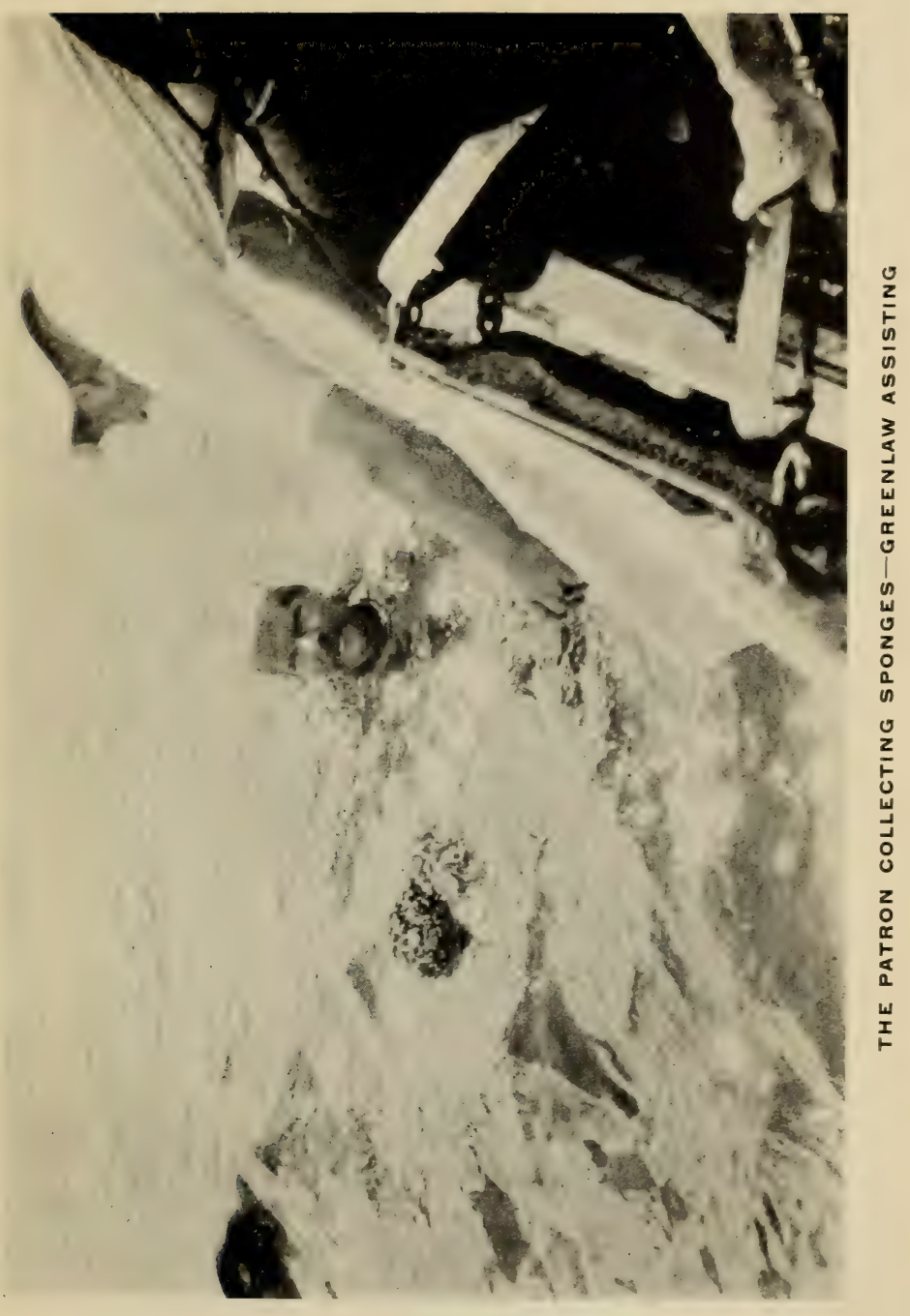



Our bulky trophies soon obliged a return to the ship for their consignment to the vivero.

Our next point of attack was upon the limestone outcrop at the deserted house. This dark colored, hard, and brittle rock arises from the water some six or eight feet, concaved below by wave action, and "honeycombed" above by erosion into a peculiar irregular surface of sharp ragged knifeblade projections. This rock, never mixed with corals nor containing any fossil remains of marine shells, must be of the same origin as that which forms the foundation of this entire forested region; it is generally encountered in Cuba wherever the coastal strip has been elevated from a previously shallow sea. The appearance of the rock that immediately lines the shore, not only here, but along so much of the Cuban littoral, is quite characteristic and very different from the rock a short distance back, although, as observed, it must be of the same origin. This narrow shore belt of very hard brittle stone of homogeneous structure owes its hardness and its peculiar appearance to a special process of weathering resulting from exposure to the salt spray dashed over it by waves breaking upon its seaward face-a process to which the 
rock farther removed from the beach is not subjected. It is to this salt spray action that the peculiar quality and the extraordinary carving into sharp knife-blade projections are undoubtedly due, but just why this combination of salt spray with alternate drying and wetting, rain-water, and sun, should produce this remarkable result I cannot even hazard a guess.

The appearance of the rock, all of reef origin, that begins just back of the shore strip and forms the floor of the entire peninsula is also exceedingly rough. It is full of holes great and small, the mass being tunneled and eroded into a jumble indescribably complicated, but the results of weathering show rounded edges and never the knife-blade effect. It is also somewhat less homogeneous and shows in some places its coral structure. As practically all the interior of the peninsula ending in Cape San Antonio is forested, the exposed rock of the forest floor is subjected to a special form of erosion which may explain its own peculiar appearance. Every little hole and crevice on the surface receives a deposit of humus, twigs, and leaf mould which, soaked in rain-water, distills some organic acids which act upon the 
limestone, tending always to enlarge the holes and thus eventually to destroy the rock. The results of such chemical action must provide a very rich soil, however scant in amount it may appear upon the surface, for upon this seemingly unsatisfactory base has sprung, as from the rock itself, a forest of slowly growing hard woods and a jungle of lesser but intensive growth. The roots of these wander deep down into the crevices searching out the little accumulations of soil hidden away below.

When we consider that all this area from Guadiana Bay to the cape is a recently elevated coral reef, the query naturally arises, Why do we see so little coral upon it? This, I think, can be explained for two reasons. Wherever a coral reef exists, whether barrier or fringing in type, a very considerable area about it is composed of the various residues from the breaking down of the dead portions of the reef. These are the large and small coral fragments near the actual reef, the coarser and finer sands, and finally the white soft mud, assorted and deposited by currents over areas often many miles in extent. When raised to form dry land by far the greater part of the 
materials so exposed consist of these various coral residues, and an exceedingly small portion of the whole consists of the actual coral itself. Furthermore much of this coral detritus is obliterated as such by the processes of atmospheric welding into rock. Masses of coral heads, bored and riddled by many living creatures, become filled with sand and mud, shells, and the tests of many lowly organisms, and when finally exposed to the air and rain-water the whole undergoes certain changes, the various component parts being partially dissolved and cemented and recrystallized to a greater or less extent. In such limestones the coral structure can only be detected by a microscope.

Throughout the Antilles the narrow little strip of honeycomb limestone upon the shore edge is peopled by a very similar group of animal forms. One would naturally suppose that so inhospitable a station would never be selected by any living creature for its permanent home, yet the little assemblage of species here found have become so adapted to their uncomfortable surroundings that they are practically never encountered elsewhere. Several crabs are numerous, particularly the red and black Goniopsis cruentata. These 
exceedingly lively crustaceans scamper about the rough surface taking refuge, when pursued, within the crevices or under projections, and, if persistently followed, leaping into the water. Of this particular crustacean, as of the majority of the commoner forms of Antillean animals, little or nothing is known of either habit or life history. What a fascinating thing to do if one but had the time to learn the stories each of these myriads of creatures could tell. The systematist will be for ever rearranging his classifications and seeking new species, and there can be no end to it; but a richer field is open to the naturalist who will become personally acquainted with his living beasts and will study them sympathetically and patiently. The eternal "Why?" that we all seek may never be found, but the nearest answer we can ever hope for must be sought from these little people of the forest or the sea. Among the mollusks of the station are the Littorinas, L. zigzag and L. lineata, showing various color patterns through an extensive range of local varietal forms; occasional colonies of $L$. angulifera are to be seen and most abundant of all are the two Tectarius, $T$. nodulosa and $T$. muricata. These marine mollusks are in a fair way of becom- 
ing in time Pulmonates. Although they still retain the normal gills of prosobranch mollusks, they have acquired power of absorbing into the blood the lifegiving oxygen from the air, if only their gills are moist, and they pass days and weeks without entering the water. Other marine mollusks that conspicuously inhabit this same sort of station are the Neritas which seem to be traveling along the same route towards a terrestrial existence. It is more than likely that all the great assemblage of land mollusks have in the remote past a marine ancestry, and the gradual process of change from gills to a lung sack is the result of just such change of habit as noted in the forms now found upon these rocks.

About the submerged base of this little cliff we searched for possible rarer forms of lesser general distribution. Such stations are usually very productive and merit careful exploration. One find of considerable interest among the mollusks was a large black Drillia of uncertain identification.

The deserted house perched upon the ledge and backed by a cocoanut grove has very high ceilings and is built of hard woods in a manner denoting something more important than the ordinary 
dwelling or bohio of the Cuban peasant. While taking an al fresco lunch upon its dilapidated veranda we speculated upon its history; could it once have served some modern buccaneers? It is strange that these Colorados Reefs, so well suited for piratical enterprise, bear no traditions of the sort. They were slighted indeed when we consider how thickly planted with Captain Kidd's treasure chests is our own Atlantic coast from Nova Scotia to Florida and how every cove and beach of the West Indies was once a rendezvous. We were afterwards informed that this deserted house had been a filibustering station for the reception of arms and contraband of war.

While resuming work about the rocks, there appeared, coming from nowhere in particular, a young man in the very minimum of tattered clothes. He poled along silently a very small boat. We fell upon him for information, he being the first human we had seen, and we accepted his invitation to visit his grandparents' house farther along towards Cape Cajon.

The approach to a dilapidated little landing stage in front of their place is through a tangled mass of turtle pens made by driving stakes close 
together in the soft bottom. The house itself stands back in a little clearing made in the buttonwood swamp and is constructed from the timbers of wrecks, the ribs of which were apparent in all directions. Curiously enough it is roofed with excellent red tiles, probably another salvage contribution from the sea. Having by honeyed words overcome some emphatic protests on the part of a large ferocious-looking dog we climbed upon the wide veranda and shook hands with an old man of keen bright eyes and quick intelligence. The women of the household shyly inspected us from behind doors. They could hardly be blamed for reserve any more than should the dog for his ill temper, for we were a most suspicious looking crowd. At any front door in the United States we would have been rejected or at best informed that the wood-pile was in the back yard and that the price of a piece of pie was so much wood cut in such and such lengths. The old man is Andres Soto and a fine type of pioneer. He is the father and grandfather of a numerous progeny that live in the same house. One of his sons is the Alcalde of Cape San Antonio, which means of the lonely forests in all directions. All of them are turtle 
hunters and wreckers and they can read and write. The usual Cuban sense of hospitality was not lacking in this remote place and we were served coffee and made welcome. In a cage hanging from the roof of the porch were two native wild doves (the white-crowned pigeon, Columba leucocephala $L$.), gentle lovable creatures that cooed softly. The old man brought out some corn and told us to feed them from our lips, and these wild creatures caressed us and begged for a return of the compliment. Our hearts went out to those birds. Such admiration had the usual result. To our embarrassment, the doves were then and there presented to us, and no refusal of the gift would be considered nor price accepted. If the women of the family, who doubtless loved them, ever winced at the parting, they gave no sign. These doves are now domiciled in the Zoölogical Park at Washington.

The young man who had brought us to the house of his grandfather now considered himself our guide and friend. He spoke of a sand beach just beyond and we stampeded for it, floundering some two hundred yards through a morass and then emerging upon just such a stretch of sand beach as we hoped from the first to encounter. 
The vegetation back of it was ideal for a Cerion colony. This is of the true sand soil kind, presenting at first low isolated bushes and long streamers of broad-leaved vines (Ipomøa pes-capre) which sprawl flat over the hot sand under a glaring sun. This is the most characteristic creeper of the Antillean sand beaches. It bears a purplish fiower. One wonders how this plant can withstand the withering heat of a sun-drenched tropic beach, lying as it does directly upon the hot surface of the dry sand. Also abundant here is the common "Sea Grape" (Coccolobis wvifera) growing directly from the sand into tall treelike bushes. Its leaves are dark olive green with reddish midrib, and from its branches depend long racemes of green grapes (purple when ripe). The seeds within the grape are large and the fruit itself is hardly edible. I believe this shrub attains in other places a height of not less than forty-five feet, but none that we observed were more than half that height. There are quantities of a dense-growing domeshaped bush bearing inconspicuous white flowers and, like the Coccolobis, growing directly from the sand (Tournefortia gnaphaloides). It is related to our common hot-house heliotrope. 
A fringe of the fan-leaf palm, Thrinax wendlandiana, forms the outpost of a scrub forest just back of the beach. The most notable tree of this scrub is one of some twenty-five feet height (Chrysophyllum oliveforme) and which on account of the sheen upon its leaves is called the "Satin Leaf." These are elliptical pointed, leathery, and thick, and are of a bronze green above and a golden brown beneath. It is related to the star-apple and bears a small round fruit.

The thick leathery leaves of so many of the sand beach plants as well as of the trees that grow near must be for some special reason related to the intense glare and heat of such stations.

In this wood from tree trunks and stems we made a fine catch of a very small Cerion of an undescribed species and took also many Cepolis supertexta.

There was little to interest us in the flotsam of the beach. The barrenness of tropical beaches is often a great disappointment to the northern visitor who recalls childhood days upon the shellstrewn beaches of his native land. One naturally expects upon any sea beach, and more than ever upon a tropical one, to find beautiful shells-and 
large ones too, that reveal from within the muffled roar of the sea. As a matter of fact most tropic beaches are too well guarded by coral reefs which catch and hold anything swept in from beyond; and as a rule the sea depths beyond are too great for the ocean surges to affect the bottom and sweep in loose material. Inside the reef the scouring force of the great ocean waves is lost and all that lives there upon the bottom is fairly secure from danger of being torn from its moorings and cast ashore. The beaches that met our childhood expectations for pink shells are those that face a gradually deepening sea for many miles out and are unprotected by reefs or shoals.

Greenlaw brought the launch and we embarked with a good wetting through the surf. Soon after reaching the schooner we spied the shore party waving from the charcoal landing and rescued them. Torre and Rodriguez had remained at the lighthouse. Simpson and Clapp were quite exhausted after their day of exceptionally hard work tramping through many miles of hot mosquito-infested forest. The auxiliary was despatched to retrieve the Doctor and Rodriguez who did not arrive till 9 or Io o'clock. We had 
begun to feel anxious about them but they seemed none the worse for wear.

As if to put finish of good measure to a day of great pleasure, activity, and success, we were vouchsafed a glorious sunset followed by a quiet night of brilliant stars. Over the tree tops to the west flashed the light of Roncali warning any that might see of dangers near by. To the southeast, just over the forest top, the Southern Cross appeared.

Tired as we all were the night seemed too beautiful to lose in sleep and we lingered along the rail while the cook sang Majorcan songs. Forward, an occasional spark of a cigarette puffed into a glow illumined for a second the nose and cheeks of some member of the crew who also felt the spell of the night and could not sleep. It was past midnight when Luis and Mulatica took full charge of the ship.

- Sunday, May 24th. We determined to devote this day to another inland foray. The route taken by the party yesterday along the charcoal burners' tram-line offered an opening into the interior, but the wide swamps made the journey very long and tiresome. At the deserted house, a ridge of 
dry land presented a possible way back with collecting conditions excellent from the beginning. We decided upon this for our point of attack, so Bartsch, Clapp, Simpson, Rodriguez, the Patron, Greenlaw, and I proceeded in the launch. Torre, with the auxiliary, set out for the lighthouse around the point of Cajon to organize and instruct a corps of native boys, children of the lightkeeper and a few others, in the methods of collecting butterflies, insects, and land-shells. The Doctor had always been very successful in training youthful collectors, having a delightful way of interesting children in natural history.

When we left the schooner no more perfect day could be imagined, but before we had progressed a mile, a lively flock of chubascos organized, gave chase, and not only administered to us a thorough soaking but filled us with horror and fear by deafening volleys from their batteries. When these chubascos, the flying artillery of Heaven's forces unlimber their guns, they strike terror and dismay into helpless mortals below. After an angry chubasco with fury of wind and bolts has passed by and is raging on as though to destroy the very earth itself we feel thankful that we are only wet 
and not dead. Following close behind these aërial squadrons come the sun's rays and a blessed peace - like a merciful Red Cross - to dry our wet clothes, warm our chilled bodies, and calm our ruffled spirits.

After landing us at the deserted house, Bartsch and the Patron with Greenlaw proceeded on to explore the waters beyond the cape and to dredge upon a certain shoal reported to exist well out to seaward of the reef and surrounded by deep water.

Passing through an old cocoanut grove back of the house our shore party filed into a path following the ridge. This rocky ridge is only about fifty to one hundred yards wide and bordered upon either side by buttonwood swamps containing some mangroves. The soft black mud of the swamps is pitted with the holes of fiddler-crabs into which the little creatures disappeared after some display of hostility to our approach.

The dry land is wooded with small trees, mostly the Cuban bast, many low broad-leaved palmetto palms (Thrinax wendlandiana), and a Metopium of uncertain species, a poison tree related to our northern sumacs. Open patches of light scrub alternate with denser groves of trees, but there 
are here none of the larger forest trees of the interior.

Throughout the woods were many hermit crabs, from tiny little fellows, occupying miniature shells of terrestrial snails, to the big hairy red Pagurids (Ccenobita clypeatus) that laboriously lumbered along, dragging their cumbersome houses of heavy marine shells. The habits of these creatures would make an even more interesting study than the red Goniopsis of the rocks had one the opportunity to watch them day by day. They are, of course, marine animals with gills; their larvæ are aquatic, and the adults spend a part of each year in the sea. For gills to maintain their functional activity on land it is necessary that they be kept in a moist condition. This the big hermit carefully attends to by rubbing them with dew from the leaves if no pool of water is about. Specimens brought home by Bartsch have been observed to dip water from a pan by their legs and splash it over their gills although they show no desire to enter and immerse themselves in the water. The specimens in captivity prefer rice to any other diet. Their terrestrial habit is likely a recent development, but it is certain they pass 
many days far away from salt water, and it is a little perplexing to understand just how they manage to get back again for deposit of their eggs in the sea. The hermits are obliged to "move" frequently, as their habitations do not grow with them. Those coming from the sea usually occupy marine shells but later they exchange them for land-shells if such can be found of suitable dimensions. The limit in size among the inland shells of Cuba is found in Liguus and Ampullaria and these are extensively used by them. They are relatively very light in weight and probably are especially desirable. The larger species of hermits, however, must eventually content themselves with the more ponderous marine shells of Strombus or Livona.

However unnatural and makeshift in character is the life of the terrestrial hermit, he nevertheless has succeeded in making good in the competitive struggle for existence. Although omnivorous in habit, it seems strange that so handicapped a creature can manage to find enough food on land. The rustling sound of these hermits over the ground tends to keep one's senses constantly alert, as it unpleasantly suggests serpents gliding through dry leaves. 
In all of our dredging operations we encountered hermit crabs of many species. Probably no single group of animals of as high rank in the biological series displays a wider range of adaptation to special life conditions than do the Pagurids. Many species appear to have chosen some particular mollusk-shell for their abodes, and in order to fit comfortably within they have altered their "figures" in most surprising fashion. One case coming under our observation is especially noteworthy-the Pylopagurus discoidalis which has adapted itself, or better, "fitted" itself, to the long narrow confines of a Dentalium shell, the entire body having straightened and elongated itself out of all semblance to the usual hermit's shape, and one claw has become beautifully modified to serve as an "operculum" or trap-door which perfectly closes the shell aperture. This modification of the claw is no rough amateurish job but is a perfect accomplishment even to the minutest details of what a protecting cover should be. Aside from the wide range of their interesting evolutionary changes, the Pagurids offer still more of interest to the nature student. They are such restless nervous little beasts, so pugnacious, 


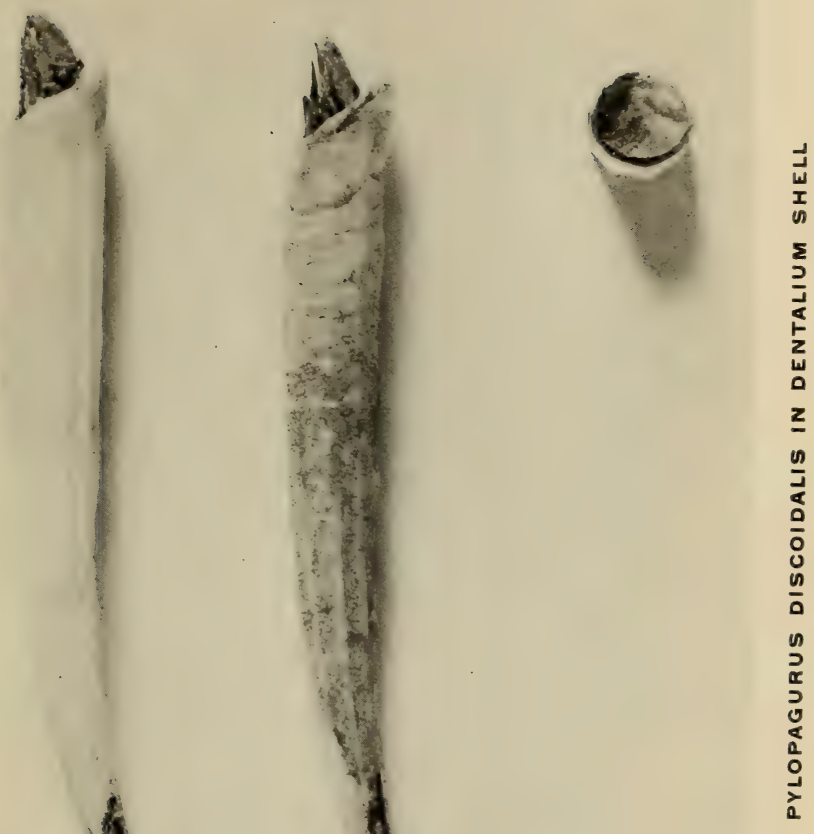



so alert and busy, so wary and cunning, they almost tempt one into a suspicion of intelligence on their part. There is a sort of "personality" connected with them which must appeal to anyone who observes them however casually.

Besides the hermits there were here also many land-crabs (Cardisoma guanhumi), large repellentlooking crustaceans, with bluish-tinged ashy gray carapace, long stalk eyes, and large weak-looking pincers. The land-crabs here are of the same species commonly met with everywhere throughout the Antilles and in Southern Florida. They sneak about warily, stepping with great caution to make no betraying noise, or, hiding behind some protecting object, they peep out in most ludicrous fashion. If cornered they put up a show of fight by rising upon "tiptoe" in a menacing attitude and brandishing their wide-open pincers. As soon as an avenue of escape is discovered they make a surprisingly quick exit. Probably no creature that has come out of the sea inspires a more general feeling of antipathy than do these large land-crabs. Yet they are eaten by the natives in many of the islands. Throughout a part of the year they remain inactive and concealed in their burrows 
near the margin of swamps, fresh-water ponds, or close to the shore, the burrows being slanting and deep enough to reach water. For breeding purposes they probably seek the sea and possibly betake themselves to offshore stations, for nothing is seen or known of them during any period of an aquatic existence. They never seem to fall into fishermen's nets, nor are they caught in the traps set for edible crustaceans in shallow water. At certain seasons they appear in countless numbers, and for a time fairly overrun the land, devouring everything in their path. Apparently anything that can be broken by their claws or masticated by their mandibles serves for food. They enter houses, rattling and scraping over floors and climbing upon tables. When swept out they sneak back. When visited by a dreadful carnage on the part of an outraged housewife or a desperate gardener, others arrive quite unaffected by sight of the slaughter of their relatives. On the contrary, they are probably attracted by their mangled bodies which are no longer capable of self-defense. Such visitation of land-crabs does not last very long. The main army gradually disappears, nevertheless some remain throughout the year skulk- 
ing about the back yard or under veranda steps.

This large Antillean land-crab is one of the most interesting examples of a marine animal that has become by special adaptation almost wholly terrestrial in habit, although he still breathes by gills. As a matter of fact very little is definitely known about their life history-even the assertion that they deposit their eggs in the sea cannot be positively affirmed. By digging into their deep slanting burrows where they hide most of the day, it might develop that their young are hatched in the water at the bottom of their subterranean retreats.

Among the wet leaves on the ground and in the little heaps of stone were many fine coleoptera and myriopods, and about the tops of the shrubs and low trees fluttered many tempting butterflies. Processions of leaf-cutting ants marched along in narrow columns bearing their irregularly shaped green parasols. Students have made close study of this numerous tribe of leaf-cutting ants, and the reports given of their life history and economy read like fiction. There can be no question but that these intelligent little creatures have reached 
a high degree of civilization in their well-ordered communal existence. They understand the value of division of labor, maintain a police force, raise crops, and store the residue against famine. Indeed, most of the essential features of man's civilization finds a counterpart in the lives of these extraordinary creatures. Termite nests occupied forks in some of the trees and their sheltered runways marked many of the trunks. Large solitary ants with black thorax and red abdomen ranged about like solitary bandits seeking their prey. Numerous other species of smaller ants were encountered living in colonies under stones and in rotting wood; groups of nervous yellow wasps clung to their hexagonal larval cells attached to leaves, and were busily building them out with gray vegetable pulp prepared in their mouths. This little ridge of dry rocky land was the richest insect locality we had seen. Of birds there were also many, although in this respect the place was not notable.

Of land-shells we collected two small Urocoptids, some small operculates, including a lovely little Helicina; a peculiar form of Cepolis (C. cubensis jaudenesi) was sparingly taken. None of us had 
ever before seen this rare arboreal land-shell. From the trees a few Cepolis supertexta were gathered but neither Liguus nor Cerion. Altogether we took some fourteen or fifteen species but only at the cost of hard labor, for land-shells were scarce and still occupying dry-weather stations. This fact seemed to us remarkable for the time of year and after so many daily rains. At Pan de Azucar we had found all life to have taken on its rainy season activities. Probably this little strip of land is exceptionally dry during many months of the year and it required more than ordinary wetting to awaken the æstivating mollusk.

We wandered back about a mile finding no new conditions. The heavy forest was not far beyond, but this, we believed, could be more easily reached from the lighthouse. Had it not been for the generous use of an ointment which had been recommended to us by a well-known sporting goods firm in New York, we could not have withstood the mosquitoes of this region. It is not likely that these pests are so bad during the dry winter months, but at this time the hot moist air filled them with energy and sapped it from us. They would have devoured us had it not been for this 
excellent salve which we applied like butter on bread. The debilitating moist heat of the scrub forest was getting in its insidious work. When we finally returned to the deserted house we were exhausted and in the physical condition of depleted vitality that invites any infection.

The dredging party picked us up in the launch a little later and all returned to the schooner. The search for an offshore bank or shoal had been unsuccessful. Several such places are doubtfully indicated upon a general chart of Cuba (there are no detailed charts of this region), and vessels have reported from time to time other uncharted danger spots off Cape San Antonio. Our Patron insisted that beyond the reefs and shoals that fringe the shore there is nothing but deep blue water. At all events the launch party were unable to locate any shallows beyond the line of green water. Bartsch made a number of hauls in seventy-two feet and a second series of dredgings at an average distance of a quarter-mile out from a point opposite the light to Cape Cajon, three to four fathoms. This is a bottom of coral sand with patches of grass and sponge and is constantly swept by strong currents. The results were not brilliant, 
although some material of interest was secured, particularly some fine calcareous algæ quite new to our observation. Another feature of the catch was some forty or more specimens of a polychæte worm belonging to the genus Ammotrypane. This species, quite unknown to us, is an aberrant form approximating in appearance the Lancelot, which we at first supposed it to be. There were also some very acceptable club-spined sea-urchins. Among the mollusks were an apparently new Calliostoma and some fine living Pyramidella dolabrata.

The amount of material collected the last two days had accumulated so rapidly that a suspension of further acquisition was imperative until a "clean up" could be made. We longed to get out microscopes and lenses and inspect our trophies more critically, but such indulgence could not be permitted. In the field the naturalist cannot study his catch, nor must he revise his notes. He can only collect, rest, and collect. Time is too precious to let a moment slip by without acquiring more material or rough information. The balance of the day was given over to the least enjoyable of our duties-the preservation and packing away of our booty. 
About dark Torre arrived from the lighthouse, in the auxiliary, full of enthusiasm over the day's results but, on the other hand, depressed by the necessity of returning to Havana. A wireless message had brought him information of a death in his family. Mr. Simpson regretfully took this opportunity to return also, he having already remained away over his time limit. About Io o'clock at night, the weather conditions being fine, Torre and Simpson departed for La Fe in the auxiliary in charge of Matas, the mate, where, all going well, they expected to arrive in time to take the early morning stage to Mendoza, some thirty miles beyond, and thence train for Havana. Their departure cast a gloom upon us all, for besides keenly missing them both, we felt that their departure marked the turning point in our expedition. From that time on we seemed to be on the way back rather than proceeding on.

Monday, May 25th. Having accomplished all that seemed possible in the two previous days about the region east of Cape Cajon, we determined to devote this day to the western extremity of Antonio and to explore the heavier forests back of the lighthouse. Cape San Antonio consists 
of two or three miles of approximately north and south line of beach, the turning point on the north being Cape Cajon. At the south end the beach gradually sweeps around to the southeast without interruption by any very definite points. To various spots, however, where the curve of the coast is slightly more pronounced, names have been given such as "Punta de los Cayuelos," "Cabo Falso," and "Punta Perpetua." These are merely map names, rather than locally accepted appellations, and testify to the fondness of Spanish cartographers for special designations of every turn in the road. As a rule these names justify themselves, if only for beauty of sound or meaning.

In about the middle of the cape stands the old lighthouse, marked in big letters "Roncali."

It is a round cemented stone tower perched upon a rock base above the beach and is of the old-fashioned solid type of construction. The light is of first order in point of visual range, casting its rays upon a danger point in the route of vessels bound to and from Central American ports. Despite its warning flash, the cape has laid heavy toll upon passing craft, and the hidden Colorados to the northeast have gathered to its stony bosom 
many more. Forty miles or so to the east, on the south side, is a land projection called Cape Corrientes which appears from the sea a counterpart of San Antonio. Vessels from the south seeking to round the cape are sometimes borne to the eastward of their course by currents, and first sighting Corrientes mistake it for Antonio, soon finding themselves in the Ensenda de Corrientes with land ahead, to the right and left; but if they recognize their error in time, they can make good their escape. Many vessels so confused have not recovered in time, and their bones upon the reefs of Corrientes make appeal to the Cuban Government for a light upon this very misleading point of land. Having successfully passed Antonio from the south, vessels bound for Havana and the Atlantic-as most of them are-have still to face even more perilous conditions. While beating against the northeast trades they fall within the influence of the lateral wash of the Gulf Stream, bearing them rapidly eastward toward the line of the hidden Colorados. For some fifty or sixty miles north and east of Antonio these dangerous reefs lie well out beyond sight of land, and to make them even a greater menace, their proximity can- 
not be determined by the lead. During the autumn and winter months frequent northers of great severity add to the other propelling forces that sweep in to the reefs, and during the spring and summer months, almost daily chubascos of fearful though short-lived violence obscure the horizon and lash the waters in this their favorite playground. A light upon the Colorados is as essential as one upon Corrientes in order to relieve old Roncali of a triple duty it cannot well perform.

On the beach between the light and Cape Cajon is a wireless station maintained by the United Fruit Company for the benefit of its fleet of white steamers that constantly use this highway. The station is in charge of a few lonesome Americans whose only communication with the world is from the top of the high single tower along the air routes to the masts of the passing fruiters.

With full collecting equipment, marine and land, we left the schooner early for the light. Before reaching Cape Cajon, a company of the wickedest-looking chubascos we had yet seen, began forming in battle array with the apparent intention of annihilating us. The Patron's words were pearls of truth,- - "this is the factory where 
all the chubascos are made." One series of these lively little tornadoes came out of the east sweeping along the north coast of the peninsula. Another company came sailing along the south coast, the two groups converging to the cape where they met to join forces. Then another corps came booming out of the southwest across the sea from Yucatan and headed also for the cape. When all met there was a lively half-hour. We ran in close under the beach and received our soaking of rain with the usual thankful spirit that that was all.

Just in front of the light there is a rickety dock somewhat protected by reefs just without. This is the shipping point for a vast quantity of charcoal. At the time of our visit, the wharf was piled high with coarse bags of the fuel awaiting shipment.

For cooking purposes throughout Cuba charcoal is the only fuel used, and the resulting demand for it is constant. There are various qualities offered, by far the best being that obtained from certain hardwood scrub trees growing in the swampy coastal lowlands, particularly the Cuban "bast" (Poiretia sp.). Charcoal-burning is the only in- 
dustry of this region. The company operating it maintains a fleet of schooners and the tramway already referred to. The life of the charcoalburner is a lonely one and full of trouble, for he must live amid clouds of mosquitoes and jejenes, and his pecuniary rewards are small.

Landing in a drenching rain we sought shelter in the lightkeeper's house where we met with the accustomed Cuban welcome and hospitality which we had learned to accept as a matter of course. Coffee and hot milk (canned) were served in glass goblets, while the numerous progeny of the house fanned us to keep off the mosquitoes that otherwise would have carried us off bodily.

At the light a wall of coarse much-weathered Pleistocene limestone rises perpendicularly about twenty feet from the sand beach, and upon this shelf or platform are built the lighthouse and its auxiliary buildings and also some few houses belonging to the fraternity of the charcoal men. South of the light, the sand beach is interrupted with patches of rock, sometimes being wholly replaced by areas of coral limestone (Seboruco), while occasional reefs project from the shore. Back of the rocky ledge of the shore is a narrow 
swamp area in which, immediately behind the light, the trees have been cut revealing across the open space a solid wall of dense forest of large fine trees growing upon the dry solid land. Along this coastal ridge, running southeast, is the track of the narrow gauge tramway, part of the same system already referred to and used by the charcoal men. The track following along the ridge crosses the swamp area and enters the heavy forest. The usual coastal belt of scrub growth and sandbeach vegetation is very narrow or wholly absent, and the more majestic forest is quickly attained.

This forest is typical of such regions, but is probably heavier here than elsewhere in Cuba. This is probably the nearest approach to the "high woods" of the low-lying damp regions of Central and South America that can be found in the island. The trees are large and vigorous and of many species including mahogany, gumbo-limbo, Spanish cedar, and a host of others that defied our attempts at identification. A thick growth of smaller trees and bushes of infinite variety fills in the space below the high branches of the major trees and the whole being bound in a living cordage of lianes. A great variety of air plants festoon 
the branches of the greater trees. Among the epiphytes, great quantities of bromeliads, in particular, Pitcairnias and Catopsis, fasten upon the branches. Many tillandsias, with unusually narrow leaves, festoon the limbs of the larger trees. We observed also several of the Echmeas, with broad strap-shaped leaves, clinging to the tree trunks. Orchids were here exceedingly abundant, both as to species and individuals but few were in bloom-one, however, an Epidendrum with yellow and orange brown, and another with purplish, flowers, were noted. We took many specimens of Oncidium with thick heavy leaves-Brassavolas, Crytopodium, and Brassia. One unknown orchid, high up upon the branches of a great tree, had hung out some lavender lamps that shone faintly and about which many butterflies and a tiny little humming-bird hovered. Some flowering shrubs illumine the edges of the forest, especially along the clearing for the track, but within its shade few patches of color relieve the somber green of the denser jungle.

The endless variety of leaf form is most bewildering. Huge thick fleshy leaves of very dark green stand out from the confused mass giving one a 
disagreeable feeling of being more alive than leaves ought to be. They have a yielding, uncanny feel to the touch and one instinctively avoids them, with a vague sort of apprehension that they might enfold and smother one in a cold clammy embrace. It would take a botanist years of study to conquer such a flora-such an appalling array of vegetation. Before it, one stands humbled and reverent; within it, one feels a sense of awe; one calls to his companion and says "let us keep together."

Showers continued to fall and many large horizontal leaves poured little cascades upon us as we disturbed them. Between showers, the air grew hot and steamy, and the mosquitoes charged in swarms and clouds. Under foot, the way is exceedingly rough and beset with holes and pitfalls in the spongy-looking limestone. Throughout the forest there appeared to be a wealth of animal life. Insects abounded, particularly about the edges of the woods or in any semi-open spot where some great tree had fallen crashing through the jungle and opening a space for the light above to flood in. Land-shells, now in full activity, crawled about the tree trunks and the stems of bushes or upon the broad palmate 


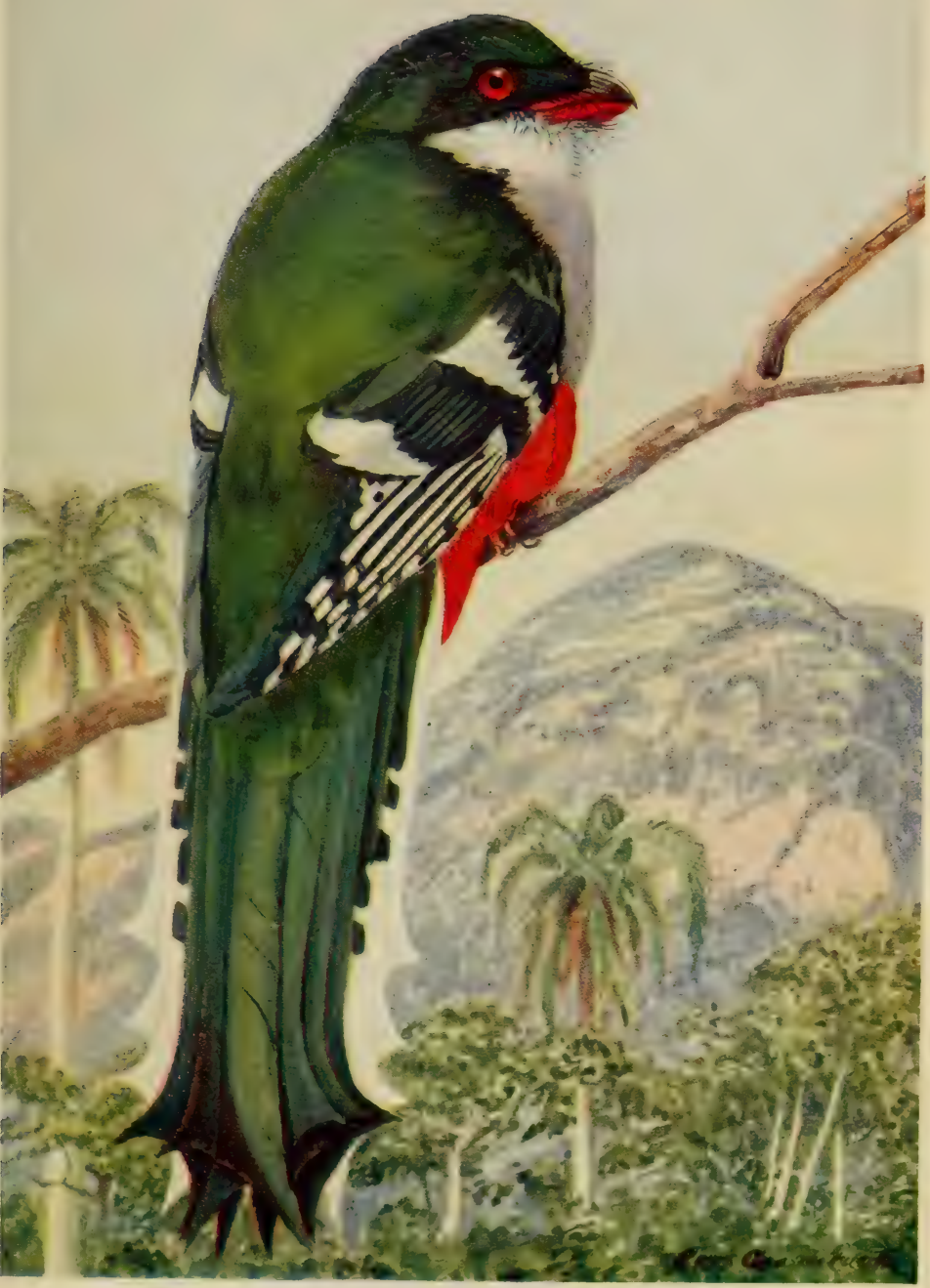

CUBAN TROGON

(Priolelus temnurus temnurus Tem.)

Drawn by Louis Agassiz Fuertes 

leaves of palmettoes. White porcelaneous Liguus, with bands of vivid green, their long sluglike bodies and tentacles fully projected, were busy rasping with armored tongues the smooth bark of the gumbo-limbos. The pretty Cepolis superiexta, black, brown, and yellow, were here abundant, and a host of smaller mollusks, alive and in perfect condition, were easily taken. Many birds kept up a chatter or song but in the thick foliage could not always be seen. We did, however, catch glimpses of the supercilious woodpecker (Centurus superciliarus), the Cuban green woodpecker ( $Z$ iphidiopicus percussus), and the white-eyed vireo ( $V$. griseus), the Cuban grackle (Haloquiscalus gundlachi). The most strikingly colored bird noticed here, barring the lovely little todi, is the Cuban trogon (Priotelus temnurus). Like the todi he is a well-finished color study from nature's studio. The top of his head is metallic purple, the entire back metallic green, the under parts pale gray (a little lighter on the throat), the posterior belly and undertail coverets scarlet; the primaries of the wing and part of the secondaries are marked by white bars; the outer tail-feathers are also tipped with broad bands of white, the combination giving to the 
bird a strikingly brilliant appearance. The trogon is inclined to conceal his beauty in thickets and rarely displays himself in the open. His call suggests that of our northern cuckoos.

The Patron, with his ancient muzzle loader, brought down from a lofty limb a large hutiathe poor wounded beast struggling to maintain its weakening hold upon the high perch and seeking to wipe away the pain in its side where a shot had entered. With a look down, as if to measure the distance of the fall, the wretched creature toppled over and fell crashing into the jungle below, to gasp out its life in the branches of a small tree. When finally recovered it proved to be a female with young, and a feeling of revulsion swept over us, including the Patron himself, who had committed the murder. We could not stifle the thought of the little ones that, awaiting in vain their mother's return, would finally perish, miserably beset with the forest scavengers before they fully starved. What a thoughtlessly cruel sport is hunting!

The Antilles are singularly poor in indigenous mammals. In Cuba there are three hutias and the peculiar ant-eater, Solenodon, which repre- 
sents the entire native mammalian fauna. The word "hutia" or "jutia" is the Cuban name for the three species of Capromys inhabiting the island; of these, Capromys pilorides is the largest and is generally distributed over the entire area. It weighs about ten pounds when fully adult and may frequently be seen in the tree tops of the forested regions. This is the one the Patron killed. The other two species of Capromys are not over half the size of the former. C. prehensilis makes use of its long rat-like tail for hanging from limbs, as do our opossums. The third species $(C$. melanurus) is confined to the Oriente province. The distribution of Capromys outside of Cuba is represented by one in Jamaica now almost extinct, one in the Bahamas, and one, strangely enough, in Swan Island; there are none in the mainland. The hutias are all arboreal rodents, but those of the mountains rear their little families among the boulders of the sierras where the feeble voices of the young can always be heard by attentive listening. Their faint cry is very suggestive of the peeping of little chickens. In the native peasant houses one often sees tamed hutias kept as pets. The species so kept is usually the $C$. prehensilis 
which resembles too closely in appearance a huge rat to be wholly acceptable as a playmate.

The large rodents, as a New World product, attained their maximum development a very long time ago, during the middle Tertiary. Since that remote time the group has been a steadily diminishing one, and the extensive land areas over which they ranged have undergone many changes. Capromys is likely a strandedremnant upon theAntilles, and its ancestral connections are difficult to trace. It is a living twig upon a large spreading tree that is slowly dying.

Reptilian life in such a forest is no doubt very abundant, but we saw less of it. Two snakes, hubos (Alsophis angulifer) were captured by Rodriguez, who was well bitten by one of them before it could be placed in the bag. The name "hubo" is applied by the Cubans to almost any medium-sized snake which is not a young boa. This particular one is a very common species throughout the island and is a lively rather than a vicious reptile. A curious habit noticed about it is the tactics employed to avoid capture. Instead of gliding away it is more liable to make directly for you and in the resulting confusion 
from so unexpected a move it disappears in the opposite direction to your pursuit. On account of the charge it has acquired the reputation of being a bad customer to meet. Its scales are rather large and smooth. The genus is common to the West Indian region and is related to South American forms of the east coast.

Before returning to the light, a survey of about a mile of the rocky beach was made. Among the numerous tide pools, in the honeycomb rock, we found by far the richest littoral collecting yet encountered. These pools are veritable aquaria of marine life. Although we took a large series of mollusks, including Livona, Chiton, Pisania, Conus, Mitra, and other representatives of the "aristocratic" genera along with many crustaceans as well, we soon realized that here was too inviting and rich a field for so hasty a visit as the lateness of the hour would permit.

Our catch was largely augmented by the material brought in by the Boy Scouts that Dr. Torre had mobilized. The children gathered about us eager to exchange their shells, bugs, lizards, and what-not, for our pennies. To compute the amounts due them required a vast deal of counting 
over of specimens spread out upon the light-keeper's floor. The entire population of the place gathered about to witness the extraordinary scene of apparently normal men buying with real money such trash as snails and beetles. No doubt our limited knowledge of the local dialect spared us disparaging comments that falling short of our understanding, exploded harmlessly about us.

During our hours in the forest, Greenlaw had made a number of hauls of the dredge in shoal water off the cape, working as closely as possible to the coral patches. He had captured some exceedingly interesting echinoderms and a few mollusks.

To do any sort of justice to this region, a naturalist should remain at least a month or six weeks in the rainy, and an equally long period during the dry, season. In that way some definite idea of the fauna and flora could be obtained and valuable observations made upon the habits and life histories of its commoner forms. For the naturalist, the advantage of a track through the forest is very great, enabling him to conserve all his energies for actual collecting work. A light launch that could be beached in times of rough 
sea, or even a canoe with a portable engine, would furnish all the craft necessary for exploration of many miles of an exceptionally interesting coast.

Our return to the schooner involved a stop at the old man's house at Cajon to take the lovable doves and a pair of tree ducks (Dendrocygnea arborea) added to the original gift. The journey around Cajon and to the ship was made laborious by the head-sea that caused our rapid launch to deluge us with warm salt spray.

The auxiliary had arrived back from La Fe during the late afternoon, bringing us our first mail from home, long expected and long deferred. All sought lanterns and quiet spots to read letters. One first reads eagerly and nervously, fearful lest bad news be found. If not, then one goes back and reads all over again, absorbing every word in the full knowledge that all is well.

Tuesday, May 26th. Like our political orators, we again had cause to "view with alarm" the everincreasing bulk of our collections which once more demanded attention at whatever sacrifice of time. Accordingly, Clapp and I resignedly set aside this day for a general clean-up of land-shells and other 
material that had been somewhat slighted in our eagerness to collect. Bartsch, Rodriguez, Gill, the Patron, and Greenlaw, started early for the cape to make a more thorough investigation of the tide pools and the rocky reefs and to search farther for some of the ground snails in the woods. The "cleaning-up" process on board continued throughout the whole day.

When lying at anchor one could generally see from the schooner's deck many small fish that hovered about. At times members of the crew would amuse themselves catching them with small hook and line. Of the various species so taken one is notable by reason of the peculiarity of its jaws. It is a very slender fish of the gar type but possessing a greatly elongated under jaw, a projection into a long sharp beak. The upper jaw is so short it may be said to have none at all. It is a species of Hemiramphus (H. braziliensis?) and appears to be very common throughout Cuban waters. The hemiramphs make long leaps out of the water and are quick active swimmers. Of the leaping fishes we frequently encountered is a Tylosurus though not usually over a foot long. These slender elongate fish with jaws prolonged 
into a beak have a curious way of leaping from the water and skipping along the surface with surprising rapidity while beating the water with their tails, the body appearing to tremble violently. The "flight" is fully fifty feet. As these have not the expanded pectoral fins of the flying-fish which serve as "wings" for sailing through the air, it is not altogether clear just how the Tylosurus accomplishes its long skipping flight, for it cannot be possible that the initial momentum acquired could sustain its weight so long above water. If there are small waves running they appear to bound from one crest to the next thus seemingly aided in prolonging their "flight."

The field party, aided by Torre's Boy Scouts, made a successful raid upon the woods at a point about a mile farther along the tracks, securing the Urocoptids and land operculates we desired, but the chief operations of the day were directed against the residents of the tide pools. The nimbleness and powers of concealment possessed by many of these dwellers of the pool failed to save them from the copper sulphate method of attack. The process is very effective, for it not only makes easy of capture all that can be seen, but it brings 
to light a most astonishing number of creatures that are not otherwise detected. A gallon or two of strong solution of the blue salt is emptied into the pool and results quickly follow. The fish succumb at once and float to the surface gasping for air. All mollusks emerge from beneath their hiding-places and there is a general effort to leave the pool. The wariest of cephalopods, the small sneaking octopi, are forced to abandon their caution and boldly expose themselves. Little crustaceans that are practically invisible upon algæ or among the rocks, the color of which they simulate, abandon their color fortresses. Holothurians and echinoids appear from unsuspected places, and worms with undulating motion swim to the surface. It is a general stampede, quick and nervous or slow and deliberate, according to the nature of the beast.

The tide pools yielded a remarkable catch of about six hundred fish of fifty-seven species, many being young of reef-dwellers, quantities of ophiurans and other echinoids, many mollusks including the octopi, worms of many species, and a fine lot of crustaceans representing several orders. A good tropical tide pool, that is, one with abun- 
dant supply of sea water and proper irregularity of sides and bottom to offer the necessary hidingplaces and relief from the sun, is a veritable biological world in miniature. To describe it adequately would require a volume; even a census of its inhabitants would cover many pages. When first approached it looks merely to be a basin in the rock painted in many colors by its algæ which gleam with added brilliancy beneath the two or three feet of transparent water. Of animal life one at first sees little. After quietly gazing into it for a few moments a movement here and there reveals some living thing of almost perfect color adaptation. Presently a school of little metallic blue fish ventures cautiously out from some crevice. A very slight movement in one corner betrays a larger fish, the movement being the opening and closing of the gills, and then the fish is perfectly apparent and the undulating dark lines of his back are quite distinct; and then there is a slight blur of sediment in the spot and the fish is not so plainly visible, for, in fact, he has gone and the place he left looks about the same as it did before. On the floor of the pool there are a number of little highly colored tufts that were not there at first. They 
are the expanded plumes of worms that withdrew into their burrows when your shadow first fell upon the pool. From beneath a rock the tips of antennæ of a spiny-lobster, likely a young one, are beginning to project out, for he is a very cautious creature with many enemies. Some particularly bright bits of color at first accepted as algæ are the mantle-edges of Lima and then it appears that there are many of them. They are exquisite. One wonders why he did not see before a curious fish partially concealed behind a sea-weed; he has two round spots at either end, one must be an eye, and it is hard to determine which end goes first. A surge from without causes an inflow of water, and the contents of the pool sways slightly. Something darts in with the inflow, circles the basin with incredible swiftness, and darts out again.

One by one new discoveries of animal forms emerge into view or dissolve from sight amid the riot of color like the changing pictures on a screen until one begins to question the normal condition of his vision, but it is simply the perfection of color adaptation of the residents of an exposed station. A large proportion of the fishes are 
the young of reef-dwelling species-marvelously painted creatures-and so the tide pool becomes a sort of nursery or training school for the larger marine world without.

Some time devoted to the reefs that project from the shore was less profitably employed although the locality yielded some good things.

Although we had not made as close a study of the reefs about Antonio as we had of the Colorados farther east, yet, from such data as we had been able to gather while dredging or passing from the schooner to the lighthouse, we felt fairly convinced that the coral patches hereabouts belonged to the fringing-reef type. No doubt the barrier reef extends along the edge of the submerged plateau to some point northeast of the cape, but a complex of inner reefs about the cape, and indeed to some extent from Guadiana West, surely indicates fringing reefs. The sea bottom off Antonio is not charted and is practically unknown. We could determine the fact, however, that very close to shore flourishing reef-corals exist in scattered patches. Deeper living reefs could be discerned below as far as the transparency of the very clear water would permit us to see. The Patron in- 
formed us that approach to the cape even in light draft vessels is very difficult even though the deep blue of the Gulf Stream seems but a stone's throw out.

The field party returned to the schooner after dark reporting rain squalls, great heat, mosquitoes, and jejenes, even in excess of the previous day. No doubt they were very bad but they could not have been worse. Some things are impossible.

Before turning in for the night, we held a roundrobin to decide upon our future best course of action. Further work about the cape seemed needless unless several weeks could be taken for an intensive process of collecting and this, of course, was out of the question. Another fortnight would about mark the time limit of our stay in Cuba, and we decided that the fourteen days could be better utilized by extending our explorations to the east of Esperanza, giving us opportunity to visit the great Pan de Guajaibon and to try out some dredging in Bahia Honda and Cabañas Bay. By leaving the schooner at $\mathrm{La} \mathrm{Fe}$ and proceeding overland to Viñales we would secure at least two days' collecting there, while the boat was making the return journey to Esperanza. 
This program was accordingly decided upon and in the morning we would bid the cape adios.

Wednesday, May 27th. The very large catch of the previous day necessitated considerable labor before the deck could be cleared for sailing. We were very desirous also of making a few hauls of the dredge in deeper water before finally leaving the cape, and believing there would be ample time for it, we set out in the launch for the edge of blue water off Cape Cajon. A number of hauls in four to six fathoms yielded very poor results beyond some algæ new to us. Further progress out was prevented by the menace of more chubascos, indeed, we scarcely had time to take shelter, close in under the beach at Cajon, before the first of the squalls struck and deluged us with rain. Following the chubascos this time there was no sun, and the elements refused to compromise. A strong wind, whipping about from one point to another, continued to blow, and the sea made up into a steep chop. All hope of further work had to be abandoned and we headed for the schooner already standing out under full sail.

After an hour or two of beating against a strong wind and heavy chop, the water boiling up through 
the lee scuppers and swirling over the deck, and with weather conditions growing steadily worse, the Patron advised making harbor among the Leña Keys for the night. Although the distance to Guadiana Bay was not over forty miles the chances were slight of reaching its shelter before dark, and the necessity of spending an uncomfortable night in the open off a lee shore would likely result. The little cove of San Juan, sheltered by one of the Leña Keys, offered us a harbor which we gladly accepted. It was an immense relief to get out of the smother, into the quiet of the cove. Once at anchor, the tables were put up, the tent raised, and we proceeded to "clean-up" the last of the catch and get it properly stowed.

The night was bad, rain and wind, but we rejoiced in our snug berth under the sheltering islands.

It seemed now that the squalls and atmospheric disturbances of the past few days had been merely forerunners of the real storm that had set in. The Patron explained that this stretch of coast, from Guadiana to the cape, is the terror of the fishermen. Mischief is always brewing above, and safety conditions below are not good-poor holding 
ground, no harbors (save one at the Leña Keys), and a shore always a lee one through the prevailing northeasterly direction of the winds. In summer it is swept by chubascos, in winter it is open to the force of frequent northers, and between times it is subject to both. 


\section{CHAPTER XV}

\section{Leña Meys to Guadiana Bay}

Thursday, May 28th. By 5 o'clock we were under way. The wind had moderated during the night and held more steadily from the east. Once clear of the keys, a disproportionately heavy sea was running, into which we bucked. An easterly current of about one knot accounted for this. During the whole tedious day of beating in long tacks against the wind and the sea, to accomplish only forty miles in a straight line, we experienced every kind and description of weather, generally adverse and disagreeable. The schooner is very stiff and carried all regular sail. Although she made excellent weather of it with easy pitch and roll there was too much motion for work. It was by far our most uncomfortable day aboard, for without employment there was no relief from the contemplation of our unhappy surroundings.

When rain squalls arrived, the crew would quickly remove their clothes and slip into trousers 
and shirts of very heavy white wool which they found preferable to any sort of rubber or oil-skin protection. One would reasonably suppose that such a covering would be intolerably hot in the temperature of $76^{\circ}$ (about the day's average). There is much that is peculiar about the relation of the body to air temperature in the tropics. Very slight changes of temperature, especially a drop of four or five degrees, are keenly felt. On a bright sunny day with a temperature of, say $78^{\circ}$, one dresses in very thin clothes and seeks the shade. If a passing shower depresses the glass to $74^{\circ}$, one may find a wrap comfortable. At $69^{\circ}$, one may positively suffer with cold, especially if the air is damp, and a temperature of $60^{\circ}$ fairly shrivels up a community. Apparently a residence in the tropics, where temperature changes are relatively slight, deprives the skin of its adaptability acquire in colder climates. Humidity in the air, whether north or south, greatly increases the effect of temperature upon the body, but this is even more felt in the tropics. In New York, for instance, a temperature of $76^{\circ}$, with a high degree of humidity, would be hot and uncomfortable. Here it gives a feeling of cold. The dividing line 
in temperature, below which moisture in the air gives a cold impression and above which it gives a hot impression, is somewhere near $80^{\circ}-82^{\circ}$. In our northern homes we think nothing of a drop of twenty or twenty-five degrees in half as many hours, or indeed in as many minutes, and a very little addition of clothes suffices for bodily comfort. In the late afternoon we reached Guadiana Bay and anchored at 6 o'clock about a mile from La Fe.

As we proposed leaving the schooner here to rejoin her at Esperanza, Rodriguez was detailed to go ashore and arrange for a conveyance to take us the next day to Mendoza. A general scramble below to find suit-cases and appropriate clothes continued up to bed-time.

What a delight it was to rest upon even keel in the still waters of Guadiana Bay! To really appreciate and enjoy the good things of life one must have experience of the bad. 


\section{CHAPTER XVI}

\section{Overland from La Fe to Vinales}

Friday, May 2oth. At daylight there was great activity aboard the Barrera, the overland party making ready to debark and the crew preparing for a continuous journey to Esperanza. Bartsch, Clapp, Rodriguez, and I were landed at $\mathrm{La} \mathrm{Fe}$ before 7 o'clock where we found awaiting us a three-horse outfit to take us to Mendoza (Paso Real), a station on the Western Railway near Guane, the terminus. The journey of twenty-one miles was completed in a little over three hours.

From the Bay of Guadiana (on the north side of the island) to the south coast is not over fifteen miles of low-lying flat savanna. This lowland area extends east almost to Mendoza, and west for a shorter distance to a point where begin the elevated coral reefs of the western extremity of Cuba. This Guadiana region is obviously but a recently and slightly raised shallow sea bottom, where reefs, if they ever existed, were smothered under 
the silt deposited by the rivers bringing down the sands and mud from the high lomas and sierras to the east. In late Tertiary times the western end of Cuba as already suggested was marked by Capes Avalos, Pinatillo, and Colorado, and the then western coast followed thence roughly a line passing not very far south of the present Mendoza. The river depositions derived from the sierras and lomas and poured into the shallow sea immediately bordering the coast became but little admixed with coral sand and reef detritus. The elevation of the peninsula is along an axis coincident with the south shore, giving to that coast line a more abrupt appearance (farallones). From the greater elevation of the south shore, the land tilts downward to the north, ending, as already noted, in a lowlying swampy area along the north coast. Not having had opportunity to study the farallones of the south coast I can only hazard a guess that the elevation of the peninsula was about two hundred feet along its axis. The uplift of the Guadiana sea bottom was much less. The differences in character and general aspect of these two regions are well marked. The Guadiana basin is a flat sandy prairie or savanna with occasional 


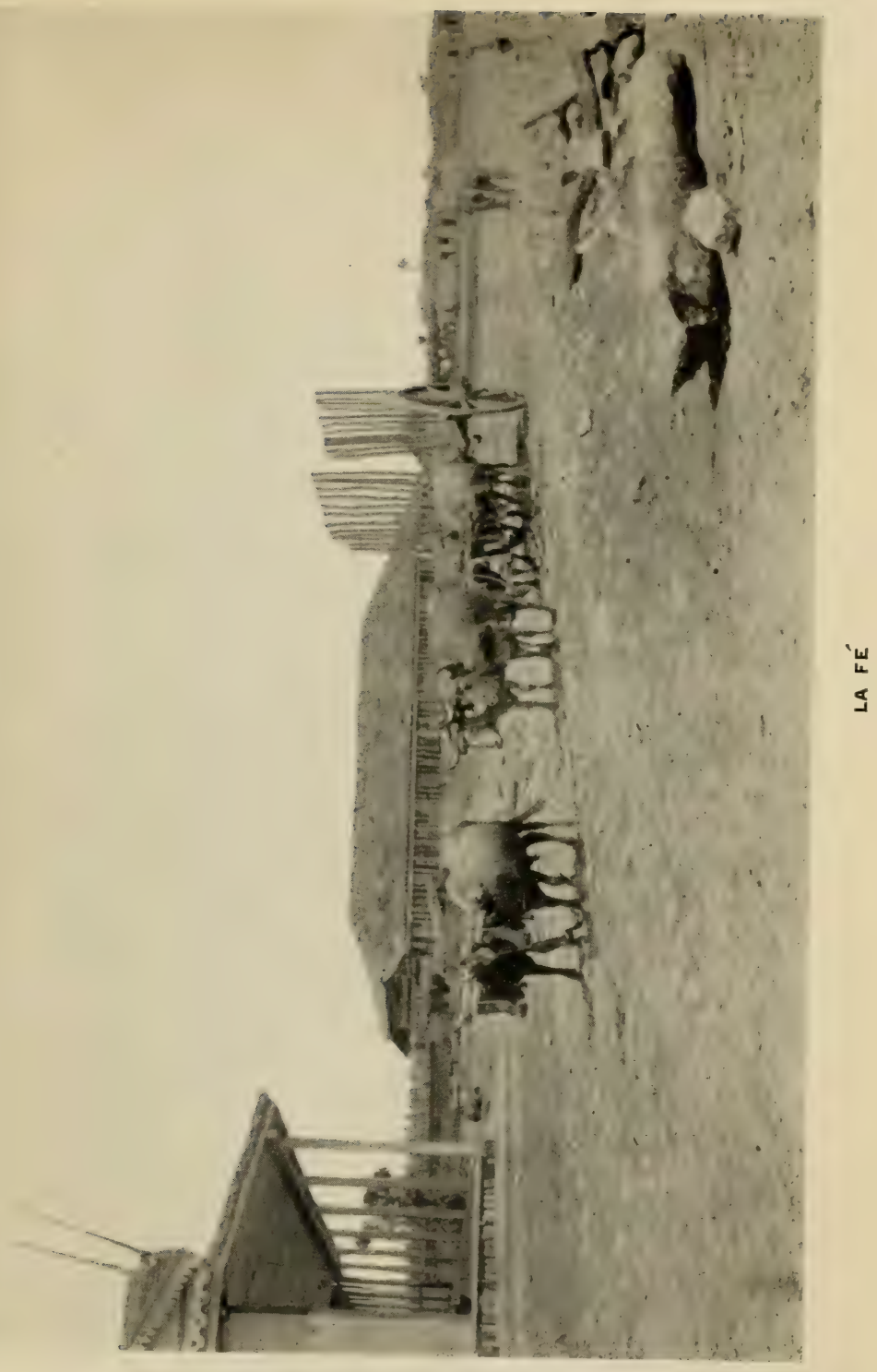



slight depressions now occupied by shallow lakes and very thinly covered by straggling pines ( $P$. occidentalis), grasses, and some cabbage palms. The sandy soil is unevenly mixed with clay derived from the sierras from which source came also a trace of leached-out iron salts that now give the characteristic reddish stain to the ground.

The country traversed along the twenty-one mile road from $\mathrm{La} \mathrm{Fe}$ to Mendoza interested us greatly, as it is different from anything seen before in Cuba. The general aspect is that of a northern country, and we were continually reminded of the pine barrens of Georgia or, better, of the pine regions of the Atlantic coastal plain of the United States. The northern aspect is made the more striking by many wild flowers that carpet portions of the ground, and also by the fact that certain of these flowers, themselves of northern type, grow in considerable profusion-a northern rather than a tropical habit. By removing from sight the occasional clumps of palmettoes it would be difficult here to imagine oneself in Cuba, or even in the semi-tropics.

Barring a few indications of fresh-water shells 
we found no trace of mollusks. Insects were scarce, save for some butterflies. Of reptiles we saw none but we were told by the driver that there were crocodiles in the lakes.

There were many birds. Among pigeons we noted the West Indian mourning dove (Zenaidura macroura), the Zenaida dove (Zenaida zenaida), and the Cuban ground dove (Champelia passerina aflavida). The Cuban bob-white uttered its cheerful note from all directions; this is a smaller, darker bird than our American quail, but the latter is also found in Cuba. A rather rare bird that we had opportunity to watch as it stood stiffly rigid to avoid detection is the large Cuban sandhill crane (Grus nesiotes). These large birds stalk about the grassy plains near La Fe usually along the margins of the shallow ponds. The ubiquitous turkey buzzard is here and the little Cuban sparrow-hawk (Cerchneis sparveria dominicensis) is even more abundant. Of other birds of prey we saw here our only example of Audubon's caracara (Polyborus cheriway). The common mocking bird of the south, to whom Linnæus gave the appropriate name of Mimus polyglottus orpheus, is usually in evidence if not always by sight. 
Bartsch our ornithologist enumerated twenty-six species along the way.

Approaching Mendoza, the two large mountains, "Sierra de Guane" and "Sierra de Paso Real de Guane," loom up high and imposing, and a gradual transition is apparent in the country round about. The sandy soil changes to clay and the vegetation becomes wholly different. Royal palms appear in groups, and the pines are left behind along with the flowering shrubs and cabbage palms. Ceibas and hardwood trees with denser foliage are met. The Pleistocene sea bottom is now crossed and we emerge upon the older mainland of Cuba-the old coastal strip. Entering the town of Mendoza and bumping along its only street, part of the ancient royal road, we reached the end of our carriage journey at a tienda opposite the railway station.

The two high sierras-better called mogotes - of "Guane" and "Paso Real de Guane," directly in front of Mendoza, are the last mountains of considerable size belonging to the north and south range, already referred to as beginning in the north with Peña Blanca. South of these two large and steep mountains is a series of small 
mogotes and rocky patches, forming the attenuated southern end of the range. Just how far they extend-if to the coast-we do not know, but probably traces of them might be found even into the Ensenada de Cortes.

Back of the inn at Mendeza is one of these small mogotes from which the road builders are blasting out a pure white limestone for road macadam. We regarded it with hungry eyes, for this would be our only chance to try out some collecting in this range. We bolted breakfast and made a dash for the spot with a time-allowance of just one hour before our train was due. The hour was well spent, for we fell upon a remarkably interesting lot of land-shells, among which was the extraordinary Urocoptis dautzenbergiana. The reported habitat of this very locally distributed snail is the large mountain of "Paso Real de Guane" and we had not counted upon the good fortune of finding it upon a small isolated mogote. We caught our train by a second's margin. The railroad passes east through the sierra belt where the elevations are eroded down to merely a rocky region of huge limestone boulders, vine-covered, and very appealing as collecting stations. The 


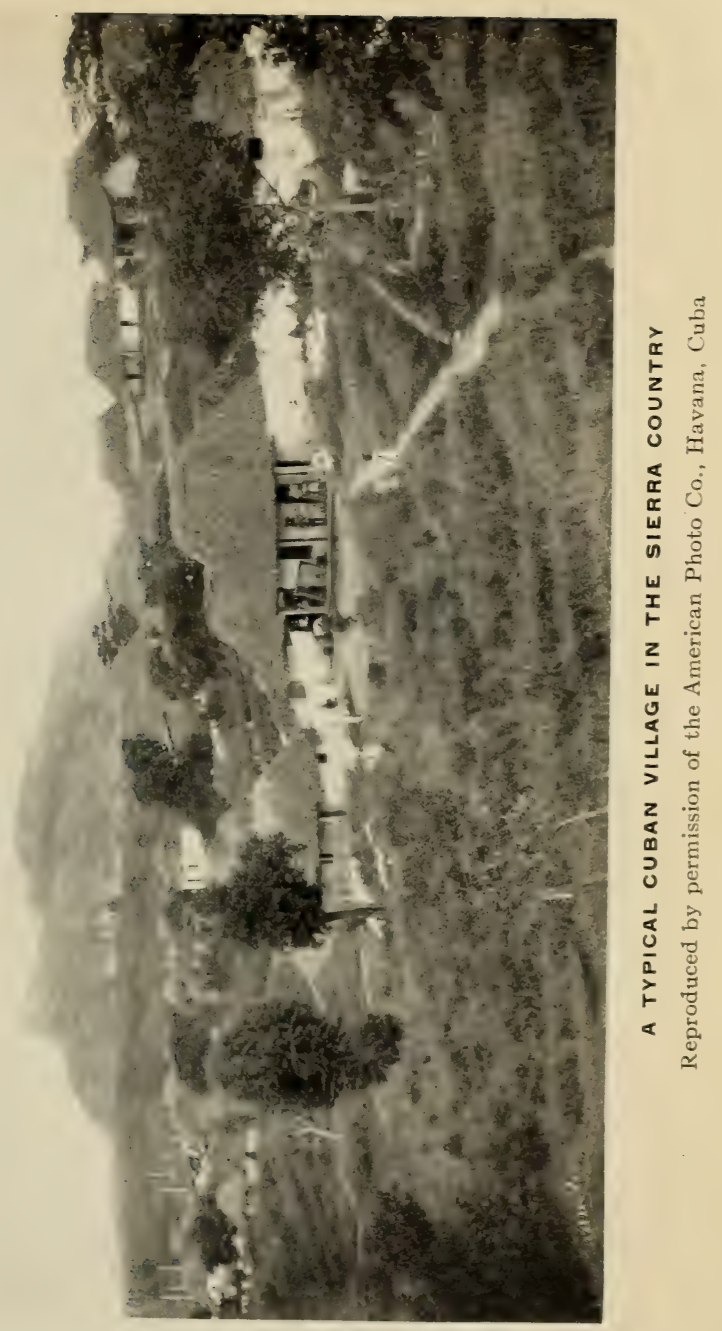



rocky belt is narrow, and having crossed it the train enters the wide Vuelta Abajo, with pine lomas in view off to the north.

At Pinar del Rio we proceeded once more to the Ricardo hotel and arranged for a motor to take us immediately to Viñales. We had the pleasure at the hotel of encountering our good friends, Mr. Morse and Sr. Diaz, of the Matahambre mine, who had so hospitably received us at their house when we had been en route to Azucar. We were very impatient to get started, as we had planned upon this occasion to make an examination of the little mogotes to the west of the road at Kilometer I4. The larger one to the east of the road we had thoroughly explored a month before, and the gratifying results of our collecting there had filled us with desire to complete the work by doing the others. These mogotes, as already noted, are remnants of a line of sierras now almost wholly eroded away, leaving but widely scattered fragments amid the lomas. Their special fauna, as a relic of a practically extinct one, is of special interest.

The two mogotes to the west of the road are about a mile away, small and inconspicuous. We 
apportioned to them an hour each, obtaining from both a valuable catch of highly prized material. On one of these mogotes, Bartsch met with a painful accident, though fortunately not serious. When hopelessly entangled among lianes and beset with "pull and haul" vines, he fell into a patch of cactus on a rock-level some six feet below, receiving many wounds from their thorns and considerable shock from the fall itself. We northern people, whose physical adjustment is not in perfect tune with the conditions of tropical life, usually suffer when there more ill effect from any shock or accident, or indiscretion, than do the natives themselves.

Late in the afternoon, we resumed our journey to Viñales, stopping for a few minutes at the top of the descent into the valley to enjoy, once again, the superb view. Words cannot picture the charm of that view any more than can they describe the fragrance of a flower.

The ideal innkeeper of "E1 Central," in Viñales, appeared to be delighted to see us and assigned to us our old room of four cots, with a veranda facing the town square and the ancient church with the bell tower. We counted upon two full days in 
Viñales before the schooner could reach Esperanza, and we laid out a scheme of work upon the neighboring sierras which would tax our endurance to the limit. Martinez, with his two mules and gouty cab, was secured for a six o'clock start the following morning. 


\section{CHAPTER XVII}

\section{Viñales}

Saturday, May 3oth. The first peep from our balcony at daybreak discovered awaiting us the ever-ready and dependable Martinez, our cochero, with his little mules and the dilapidated cab. No doubt this unhappy vehicle once did smart service for some opulent private owner in Havana, and made the usual afternoon tour of the Prado and Malecon with as proud bearing as any other aristocratic turnout on that aristocratic driveway. Losing the bloom of youth, it descended to the humble cast of a cab for hire, and for many years rendered excellent service. When the infirmities of old age reduced its usefulness below the Havana standards, it was banished to Pinar del Rio, where presumably, with the other outcasts, it drifted into senile decay and was eventually abandoned and left for dead upon some scrap pile. Then it was rescued by our own Martinez, who, with pieces of wire and rope, bound up its wounds and with 


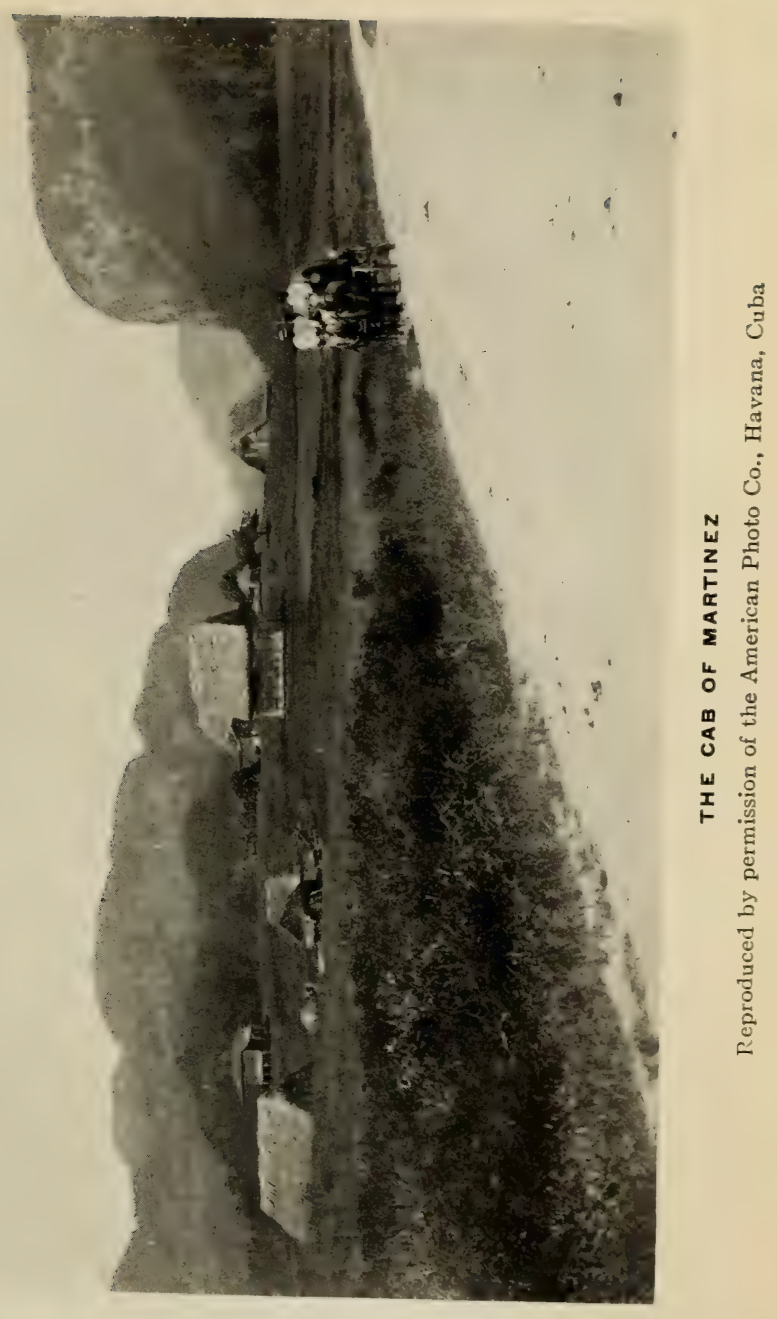




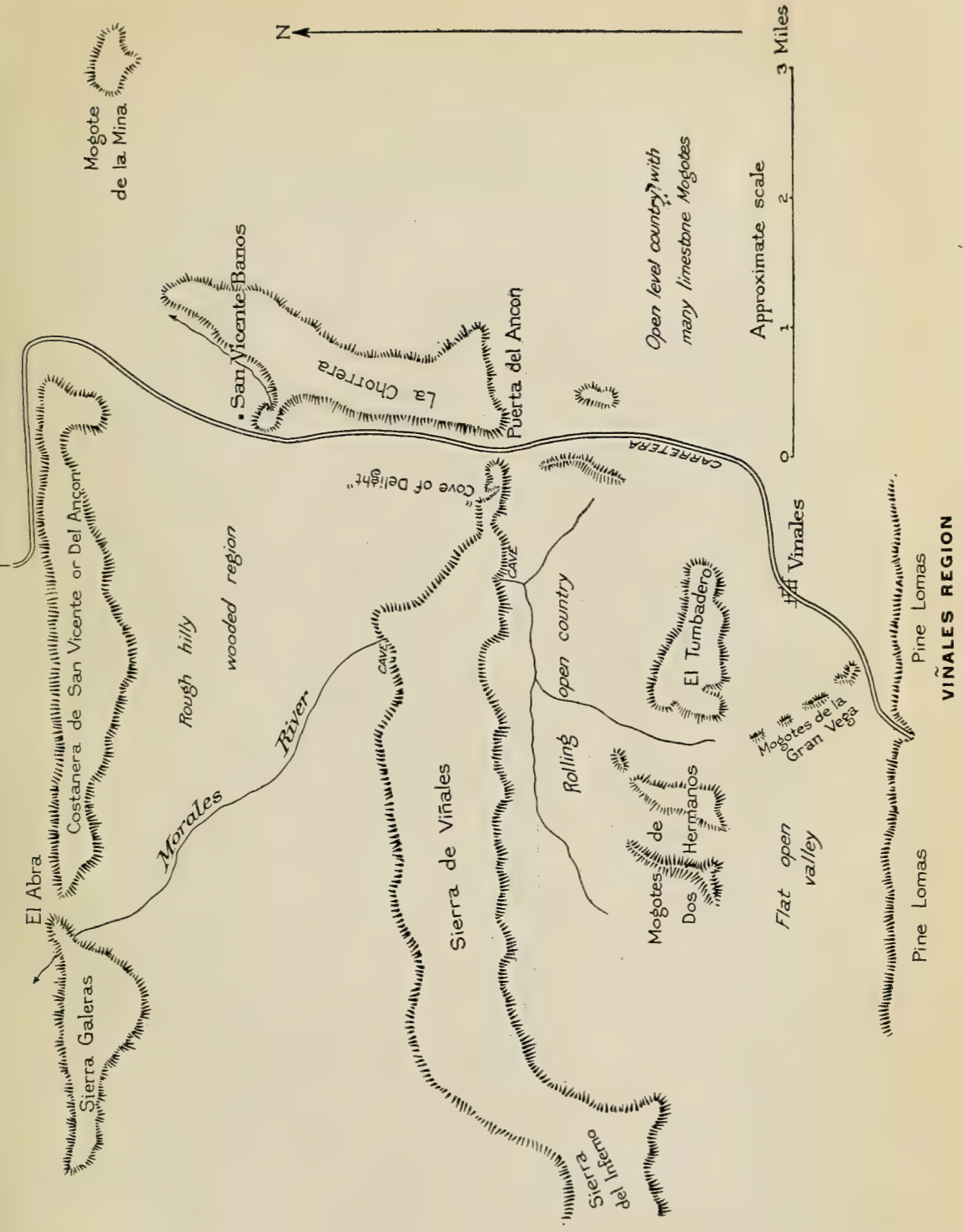

paint anointed its sores. But its spirit is broken. The once haughty vehicle now rattles up to the inn with many a protesting creak and groan as though begging for rest-eternal rest. But Martinez is no believer in rest, while duty still calls.

It was for land-shells chiefly we wished to devote two days about Viñales. Although the region had been considerably worked by various members of our expedition upon other occasions, there still remained for exploration certain unvisited mogotes and parts of the sierra. As before suggested Viñales offers exceptional advantages both for intensive collecting and for study of geographic distribution, for within comparatively easy access of the town several of the sierra systems converge, and are near together. We believed the quickest solution of all sierran faunal problems would be found in the mollusks and for a full collection of these from every mogote and every sierra we felt the time and labor would be well spent.

A series of four mogotes (beginning at a point near the road, about a mile southwest of Viñales) traverse the valley diagonally toward the western end of the large masses of E1 Tumbadero and Dos Hermanos. These four small mogotes appear like 
castellated islands in the green sea of the valley and are richly clothed in the characteristic sierra flora. They bear the local name of "Los Mogotes de la Gran Vega."

Approaching the first of -the series nearest the road, we divided our party of four into two parts, each taking one side of the mogote and working around to meet at the farther end, thence to proceed to the next and repeat the encircling process, and so on to the final end of the last elevation. In this way, proceeding slowly and deliberately, we gathered a harvest of specimens from each one.

There had been some rain at Viñales, but it was very apparent that the wet season was not nearly so far advanced as we had found it to be farther west in the cape region. The mollusks had scarcely emerged as yet from their winter's hibernation and had to be searched for more diligently. The sky above was deep blue and the air felt dry and exhilarating, contrasting agreeably with the moisture-laden atmosphere of San Antonio, although the temperature was quite as high.

The catch from the Vega mogotes represented but few species; their specific affinities are wholly with the main range north of Viñales, showing the 


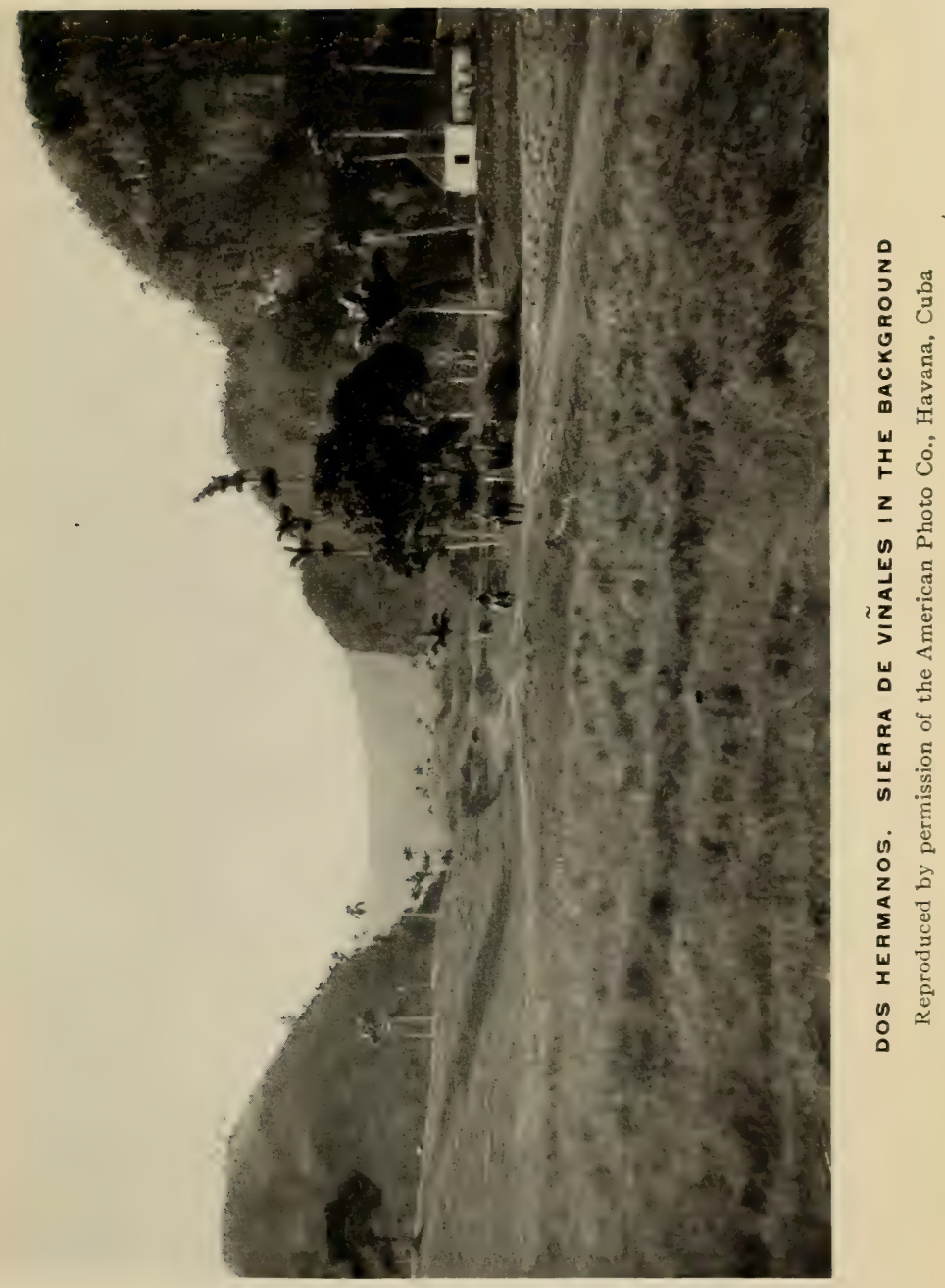



mogotes to be remnants of that system and of no relation to the series now represented by the mogotes of "Kilometer I4."

Having completed these four hills to our satisfaction we proceeded next to the west end of Tumbadero. Here we could expect only to find the regulation species of the sierra unless possibly we might stumble upon one or both of Wright's "lost" species, a possibility that always stimulated us to extra effort when in the neighborhood of Viñales. Our own collecting for many miles about Viñales, as a headquarters, had brought to our bag many species of land-shells not noted by Charles Wright, but we had never found even a trace of the particular two mentioned and to which he had given the simple locality designation of "Viñales." To one, however, he had added "En los paredones de los despeñaderos de Viñales" which means "lofty unscalable places." In a region where there is little else than despeñaderos the designation is not very positive. Wherever this remarkable Blcesospira echinus does live it must be very abundant, for Wright took enough of them to distribute specimens very generally among the collectors of the day. As this genus is unique 
in the one species and wholly different from any other land-shell of western Cuba (its one affinity being in eastern $\mathrm{Cuba}$ ), we were particularly desirous of finding it for anatomical study. An exhaustive search along the base of the high walls of Tumbadero, and far up into its recesses, failed to produce any evidence of its existence. An equally persistent search along the eastern face of Hermanos also gave negative results.

About the open fields, and especially, perhaps, near the base of the mountains, we noted an abundance of the "sensitive plant,"-Mimosa pudica. It is a low-growing plant covering with its doubly compound pinnate leaves the ground in patches of several square yards. The "sensitive" quality that gives it its name is displayed in its curious habit of suddenly shrinking when disturbed. This shrinkage gives an impression of a sudden wilting as though the shrub had been scorched. When touched, however lightly, the leaves of the entire plant instantly droop and fold up. The more vigorous the disturbance the wider the area affected. Can this be some highly specialized form of protection against browsing animals that reject dead fodder? This curious contraction of 


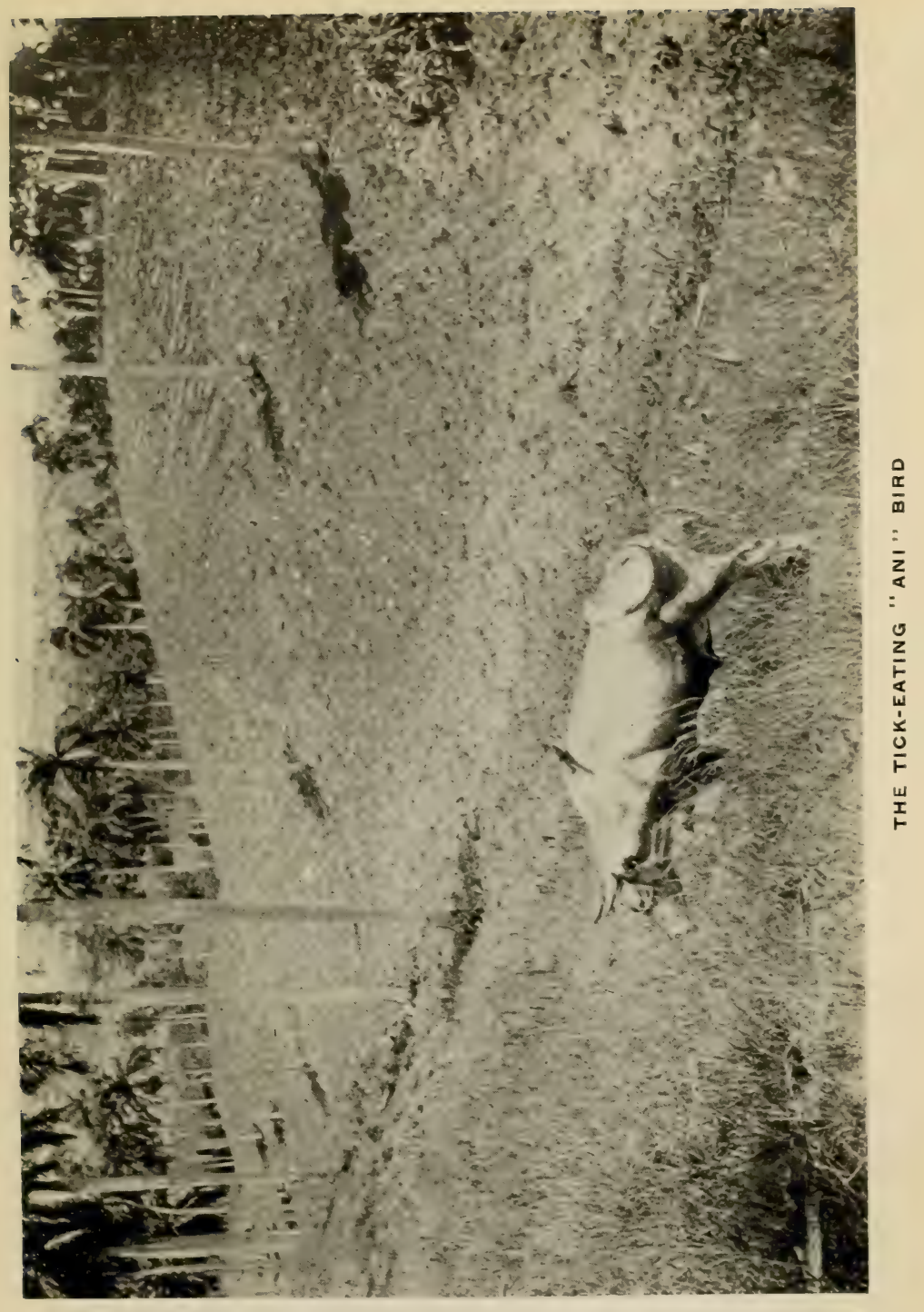



the protoplasm of the plant cells under the stimulus of a touch is not without parallel in certain other plants where the quality is developed to even greater refinement, notably in the fly-catching blossoms of some well-known species. In that case the weight of a small insect causes the flower to close upon and imprison its victim. The Mimosa soon regains its lost "freshness" if not further molested.

The red soil about the base of the sierras like that of the famed Vuelta Abajo is very rich in the elements required for the finest quality of tobacco, and to this purpose the greater part of the valley is devoted. Cultivation is often extended to the very base of the mountain walls. Here the alternate crop is corn and malanga. The valley area is divided into a great number of small farms of not over twenty or thirty acres, upon most of which is a small palm-thatched hut or bohio. Each household must obtain its supply of water from the nearest river, and this is accomplished by the laborious process of dragging a barrel upon runners by horse or oxen, to and from the source, sometimes quite a mile away. This labor is constantly going on, usually under direction of 
the younger members of the family while the men are at work in the fields, plowing or otherwise tending their crops. Stolid oxen, with heads bowed low under the heavy yoke, strain at the primitive plow while their drivers shout orders to them. Oxen not in use, graze in fields fenced off for them, and upon the back of each sits perched a black bird, industriously hunting for ticks. When approached these birds fly in groups to the nearest fence uttering in constant repetition their peculiar cry of "an-nee, an-nee." It is known as the "ani" (Crotophaga ani) and is found everywhere throughout the island wherever there are cattle, even to the outskirts of the larger cities. The bird is black with a metallic sheen, about the size of a small crow, and carries a peculiar crest upon the upper mandible. They live upon the ticks or other parasitic insects on cattle, a decidedly unpleasant diet to contemplate. This is by far the most conspicuous bird in Cuba; the northern visitor is astonished by the unusual habit of perching upon the oxen who seem wholly indifferent to their presence upon their backs. Other birds hop about in front of the grazing cattle to catch the insects disturbed by the big beasts 


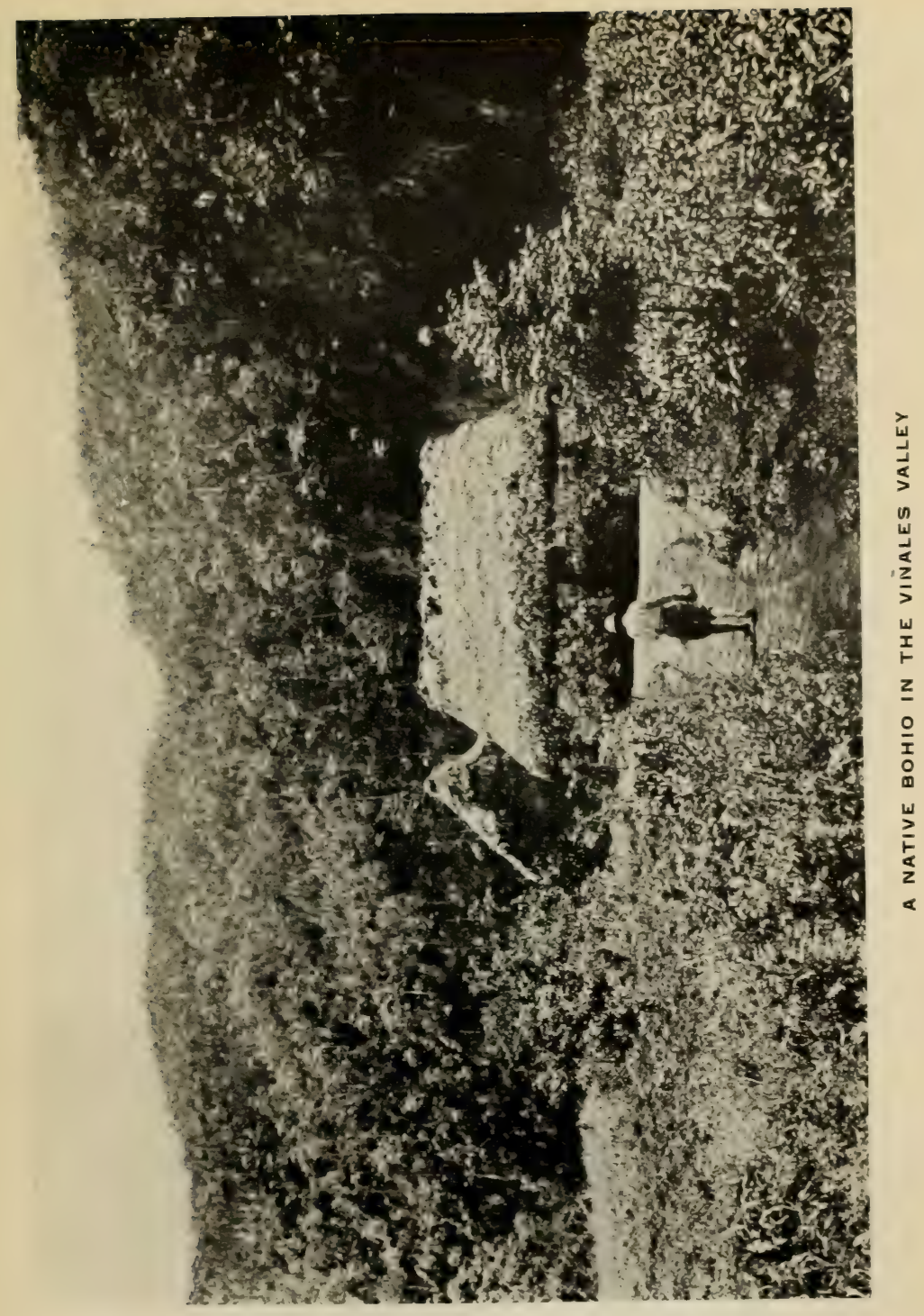



nosing about the tufts of grass. In front of some of the bohios are a few flowering shrubs planted for decoration. Usually about the houses there are several small naked children, always a dog or two of ferocious mien, some chickens, a few pigs and cats, sometimes a goat, generally a parrot, and not infrequently some gamecocks tethered to stakes.

Crossing from Tumbadero to Hermanos, a short quarter-mile over the level valley floor, two of us entered a bohio to beg a drink of water. A very old woman greeted us with apologies that she could not offer us coffee, as she possessed no sugar, and coffee without sugar, we must know, is like a soul without hope or redemption. She wished to know where we came from. "From Washington," a place she had never heard mentioned, but, in general, from the United States. "Holy Saints, and how long does the journey take?" "Several days." "God Almighty, and have you wives and families there?" "Yes, most of us have." "Christ Jesus and his Mother of perfect purity, have you left them there alone?" "Yes," we guiltily confessed, "we have, but we are determined to return to them, come what may." "It is well," and she 
accepted some cigarettes as proof of friendship but not as pay for the water.

The greater part of this rich land is owned by absentee landlords. There can be no high degree of stability, political, social, or otherwise, in a land where the masses of the people do not own their own homes. The peasant farmer, who can sit in the shade of his own fig tree after his work is done, thinks twice before he will exchange his plow for a rifle in the cause of some plausible orator who wishes to be president. Cuba must encourage the small ownership of land in her population for no less reason than for her stability as a nation, even though the system may not make for the "economic efficiency" of large estates. It is enough for any country that its manufactures should be corporate owned and controlled, possibly even better that they should be, but it is not good to make peons of peasants.

The rank and file of the Cuban population is not warlike, nor even disputatious. They merely ask for security and an opportunity to make a living. They are, however, impressionable and temperamental. An orator too easily lashes them into frenzy with a stock-in-trade recital of their 


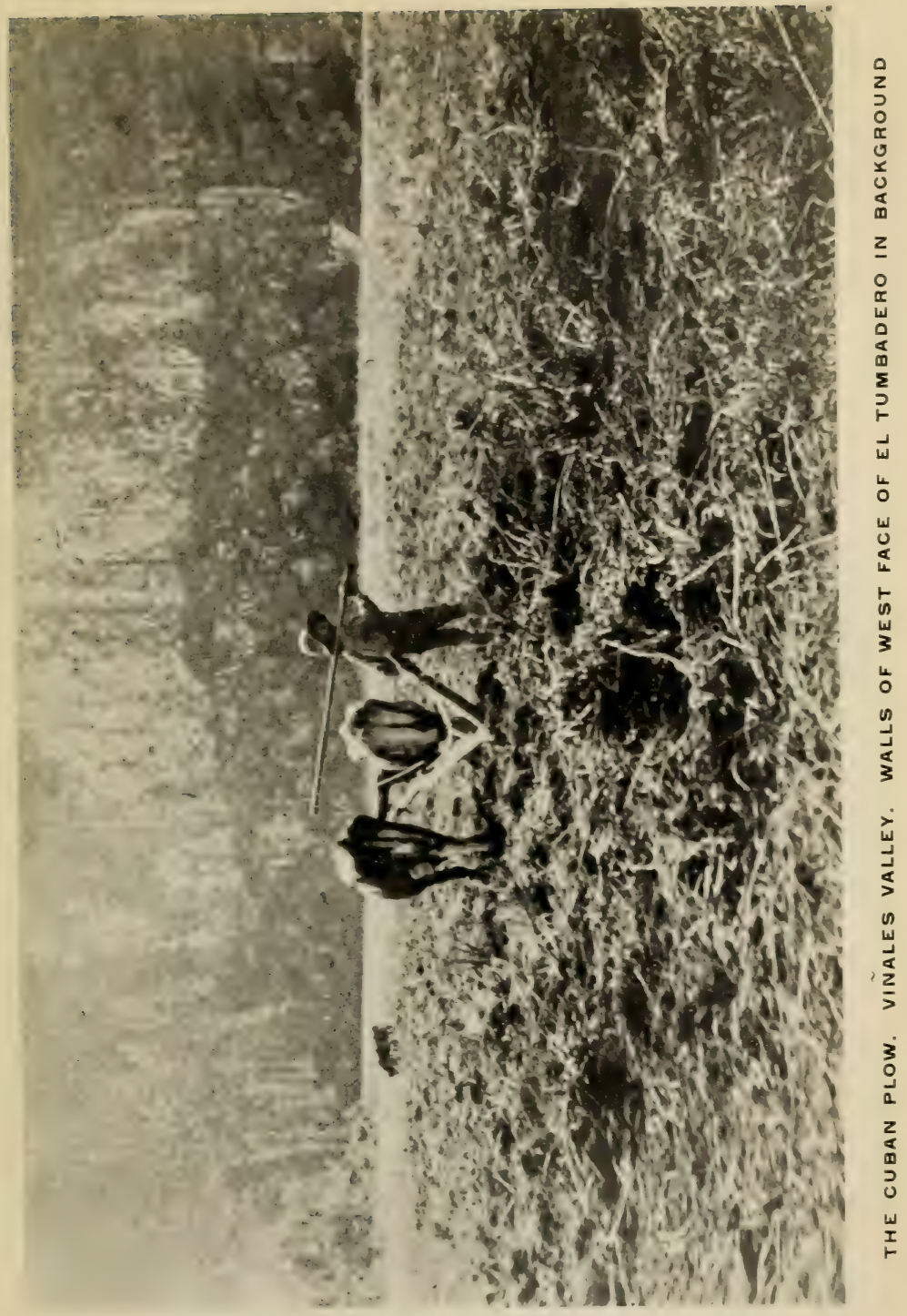



"wrongs" and some sky-rocket patriotism that would make an American audience laugh. $\mathrm{He}$ does not fight because he likes to, as most Americans believe, but he fights for the same reason as would an American. The difference is he is more easily convinced that he ought to fight and that by so doing he will right some terrible economic wrong. 


\section{CHAPTER XVIII}

\section{Sierra de Viñales}

Sunday, May 3Ist. The town of Viñales is dominated by the forested height of E1 Tumbadero which conceals from view the main range (Sierra de Viñales) to the north. The southern face of the main range presents an almost continuous paredon, or vertical wall of rock, extending from the Puerta del Ancon, on the east, to a western termination far beyond sight. This paredon is buttressed by a high and very steep talus covered with guinea grass and in places by a thin scrub forest. Above this talus of some two hundred feet elevation the paredon presents the somewhat unusual sierra feature of an approximately horizontal stratification which is warped and undulating, showing the effect of former great pressure and strain. The rock is discolored and considerably altered by metamorphic process. It is just possible that the limestone of this southern range of the Organos Mountains is a shade older than that 


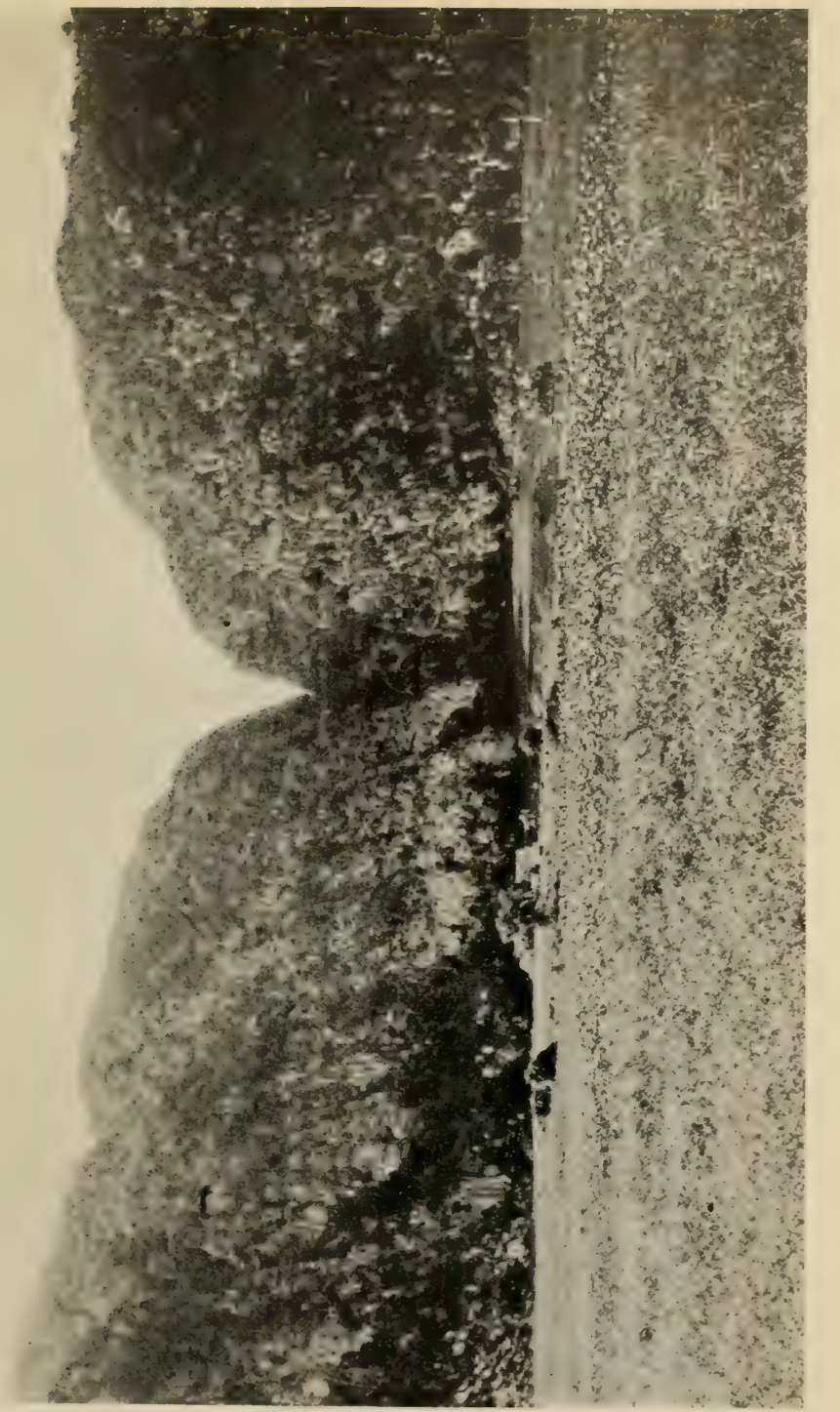



of the northern system (the Costanera), but the folding upward of the two was certainly contemporaneous. All of the mogotes of the Vinales valley, including the large Tumbadero, the Dos Hermanos, and the many smaller ones scattered about the valley floor are clearly but fragments of the main sierra now wholly detached and isolated by erosion. The ammonites, which Dr. Torre has been collecting for several years, come principally from the rocks of this southern range and indicate a probable jurassic origin of the limestone. As heretofore noted, the mogotes about "Kilometer I4" do not belong to the Viñales range, but together with the Cerro de Cabras hills farther west, represent either remnants of a third line of jurassic sierra that once followed a course parallel with the existing ranges, or possibly a later Tertiary deposit upon the flanks of the older mountains. We lacked sufficient data to determine this question. The westward extension of the Sierra de Viñales is locally known as "La Penitencia" or "Sierra del Infierno," two names well chosen in the opinion of anyone who attempts to climb the talus to reach the walls above.

To surmount this talus was our program for 
the day. Possibly the "despeñaderos" of Charles Wright (where lived the elusive Blcesospira echinus) were these very same paredones, and we determined upon their exploration. From the town it is possible to go in Martinez's veteran cab around the western end of Tumbadero and to proceed thence about half-way across the intervening valley extending to the foot of the main sierra. The balance of the way must be accomplished afoot or on horseback.

While proceeding along slowly under the shadow of Tumbadero through an atmosphere surcharged with the uncomplimentary remarks of Martinez to the mules and with occasional stops to retrieve a lamp shaken loose and shed by the cab, we came to a sudden halt; just such a halt as a motor-boat makes when the clutch refuses to disengage in front of a solid pier. Our mules could get over or under or around every kind of obstacle in the road yet discovered, but they declined to pass over a maja snake lying across our path. The size of snakes depends very much upon the observer's state of mind, but this one dispassionately measured eight and a half feet.

The maja is the only Cuban representative of 


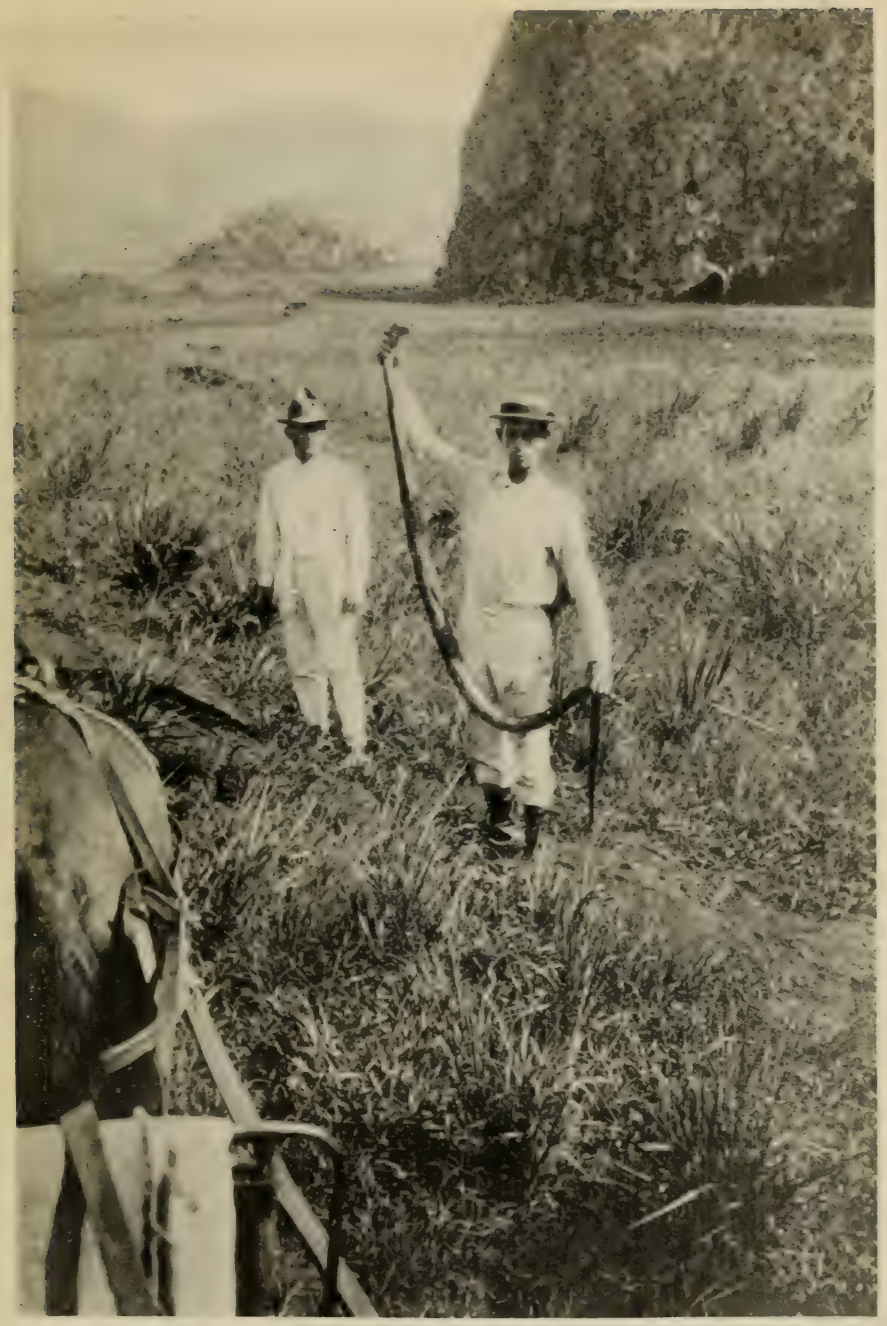

RODRIGUEZ AND THE "MAJA" 

the large boas. Generally distributed over the island, it is more abundant in the mountains and in the swampy coastal regions. It is regarded as harmless but much disliked by those who raise chickens, and that includes the bulk of the rural population. As a sort of reprisal, the natives try out an oil from the maja's intestines that is believed to possess medicinal value. $\mathrm{He}$ is a night prowler not often seen by day. He hides in caves and among the boulders of the sierra, or in the dense foliage of trees. The swamp variety (once considered specifically distinct from the highland form) passes the daylight hours immersed in the water with his elongated head projecting upon some black root or branch. They depend largely for food upon the supply of hutias and follow them relentlessly from tree to tree, the agility of both being about equal. The snake is hardly large enough to be a menace to children; however, there are native records in the Cubitas Mountain region of fifteen-foot specimens, but such records need confirmation. The Cuban naturalist, Gundlach, whose word should be good, even goes further than this and declares the snake attains a maximum length of twenty-one feet. Barbour, 
who has collected many majas, gives twelve feet for present-day specimens, and the conservative Stejneger says an eight-footer is very large. This is the Epicrates angulifer and is confined to Cuba; it is very closely related to the Haitian boa. Like all the boas, they remain for days inactive and sluggish, but the maja is more than usually irritable and resentful of disturbance, striking swiftly and inflicting a painful though not poisonous bite.

Cuba shares the good fortune of the other islands of the greater Antilles, in being wholly free from poisonous reptiles. None of the pit vipers of our moccasin-copper-head-rattle-snake type, so extensively distributed over the mainland of North and Central America, seem ever to have found lodgment in these tropical islands. The venomous Elaps, represented by a number of species in South and Central America (and by the coralsnake in the United States), are also wholly absent from the Antilles. The only dangerous snake in any of the West Indies is the fer-de-lance of Martinique and some other islands of the chain south of the Anegada channel.

The origin and development of a poison sack and hollow, or grooved fangs to inject venom into 
the circulation of a victim, is one of the most interesting problems in biology. There are, for instance, certain families among the Ophidians that include genera of both venomous and of nonvenomous snakes. The fact that a development of the poison glands took place in widely differing genera and in distant parts of the world, quite independently of each other, would indicate that snakes, as a type of animal life, possess a tendency in that direction. If, therefore, the poison apparatus is of benefit to so many kinds of snakes, and all have a tendency to its development, why have so many orders of them no such provision? It is probably true that the majority of non-poisonous species are the more active snakes relying more upon alertness and agility to meet their life requirements, while the reverse is generally the case with the poisonous ones that depend upon their specialized poison equipment to protect themselves. There are exceptions, however, as in the case of the king cobra of India, and to a lesser degree in the fer-delance of Martinique. Among the snakes of our own country, one cannot fail to contrast the sluggish sedentary habit of our pit vipers with the nervous agility of the harmless forms. As a mat- 
ter of fact in most instances prowess in battle must be accorded the non-poisonous species, notably well shown in the case of the king snake of southeastern United States. One can easily fancy what a perfect animal of offense and defense would be a serpent possessing both the agility of the colubers and the poison equipment of the vipers. Such a creature, unless handicapped by some weak spot in his armor, such as defective sight, smell, or hearing, would rule over all the other dwellers of the forest.

A number of smaller species of snakes were captured this day by the intrepid Rodriguez, our enthusiast in that line of study, who employed the simple method of seizing them in his hands and taking the consequences. Courage and cowardice, when analyzed, become largely a matter of knowledge and experience. He knew to just what extent any particular snake could harm him and hence he could overcome the instinctive fear we all have for bodies that glide and coil. To see Rodriguez hurl himself upon a vicious snake and transfer the writhing creature to a bag at first transfixed us with horror, and yet a perfectly harmless hermit crab lumbering about the schooner deck would keep Rodriguez nervously 
apprehensive. In time, however, he worried less about the hermits, and we, on the other hand, became sufficiently valiant to help in the capture of his snakes-provided they were decently small and not too resentful. One of these (a small boid, Ungalia maculata) Clapp and I undertook to capture while Rodriguez was busy at something else. He was probably not over two feet in length but the amount of excitement and nerve force expended on our part would hardly be more than justified in the capture of Lange's fifty-foot Amazon snake. Ungalia represents a genus of smaller Cuban boids. It is also met in other islands of the greater Antilles and has Central American affinities.

From the top of the talus, a superb view of the valley below is obtained. Above, the paredon rises perpendicularly, though not smoothly as is usually the case. Here the horizontal strata permit of a form of erosion that provides many little shelves and projections upon which air plants and agaves find lodgment and relieve the monotony of a solid wall. From above, the sierra forest sends down long streamers of lianes and vines that often swing free from the wall. Here and there clusters of I6 
wasps' nests hang from the under side of projections and to these cling bright brown wasps with amber-tinted wings. These maintain a selfsatisfied noli me tangere attitude, as though conscious of the world's respect, and they ignore our presence. Less formidable creatures would get into a flutter of excitement over the near approach of despoiling man to their nests, but these little demons rely confidently upon their reputation and expect no molestation. Needless to say, if they do get it, it is purely accidental.

We followed the foot of the paredon along the narrow shelf at top of the talus about a mile where it abruptly stops and the wall is bare down to the valley floor. We were obliged to descend without having made a very satisfactory catch of land-shells.

Proceeding on, a mile farther along the base of the range, we found an excellent field of operation in a mass of huge limestone blocks covering quite an acre in extent and piled up against the mountain side fully a hundred feet. What a mighty crash there must have been when this mountain peak toppled to earth from its lofty position. The rock is now smothered in vegetation of be- 
wildering variety and bound tight in miles of green cordage. Here we made a splendid catch of land-shells, but still no trace of the "lost species" of Wright.

On the return trip to the town time was taken to survey the western face of the large twin mogote of Dos Hermanos and also to explore a small detached satellite of these. Nothing of special importance was taken from either station.

At the hotel we found a telegram from Dr. Torre from which we concluded he would be unable to rejoin us here for the balance of our trip to the eastward. This was a great disappointment, for besides the pleasure of his company we had hoped for his aid in making the proposed Guajaibon expedition.

In the late afternoon Greenlaw and Gill arrived by motor car from Esperanza reporting a good run in the schooner from La Fe. No attempt had been made to collect en route. Instead of returning immediately to the schooner we decided to spend another day about Viñales to give the crew a rest and an opportunity for a run ashore. This would also enable us to examine more closely the north 


\section{CRUISE OF THE BARRERA}

side of the Sierra de Viñales, and to explore the river that, flowing under La Chorrera, emerges at the Baños de San Vicente. We hoped to get there some blind fish and crustaceans. 


\section{CHAPTER XIX}

\section{San Vicente Baños}

Monday, June Ist. A certain holiday spirit possessed us this lovely morning, and it soon became apparent from the general levity of the crowd that no very serious work would likely be accomplished. To reach the boat by night and to sail the following day would be quite sufficient. The boxes and bags of the two previous days' collecting were made into parcels, bound in heavy twine, and all the suit-cases and other impedimenta were packed into the groaning cab, and then as many of us as could follow piled in on top. We always felt like cheering when our cab drove up. Martinez opened the throttle by a snap of the whip and we rattled and wheezed along the carretera towards the pass-La Puerta del Ancon. At the narrow pass we left the vehicle with orders to Martinez to continue on to the Baños and deposit our luggage. Then we proceeded afoot to the "Cove of Delight," Clapp and Bartsch continuing 
along the base of the sierra beyond. About noon the party reassembled at the house of Señora Piad and received a delightful welcome from that hospitable family. We must indeed have made a formidable party for any hostess to invite to luncheon. At the table an amusing incident occurred, that, for a brief moment, embarrassed the Señora, but set us all into a whirl of laughter, establishing an entente cordiale which only the general appreciation of a humorous situation can bring about. A venturesome chicken entering the dining-room suddenly flew upon the dinner table and made a dive for the nearest platter of food Those sitting close to the scene of the raid attempted to shoo away the unwelcome guest, but only succeeded in driving it down the full length of the table, leaping from one side to the other to escape threats from every quarter. During this running of the gauntlet, the chicken managed to step (actually!) into every platter of food on the table and at the farther end, amid a general hostile demonstration, it succeeded in seizing a steak from Bartsch's plate and carrying it overboard in its retreat. Any fowl that could accomplish so much, deserved the booty, but such 


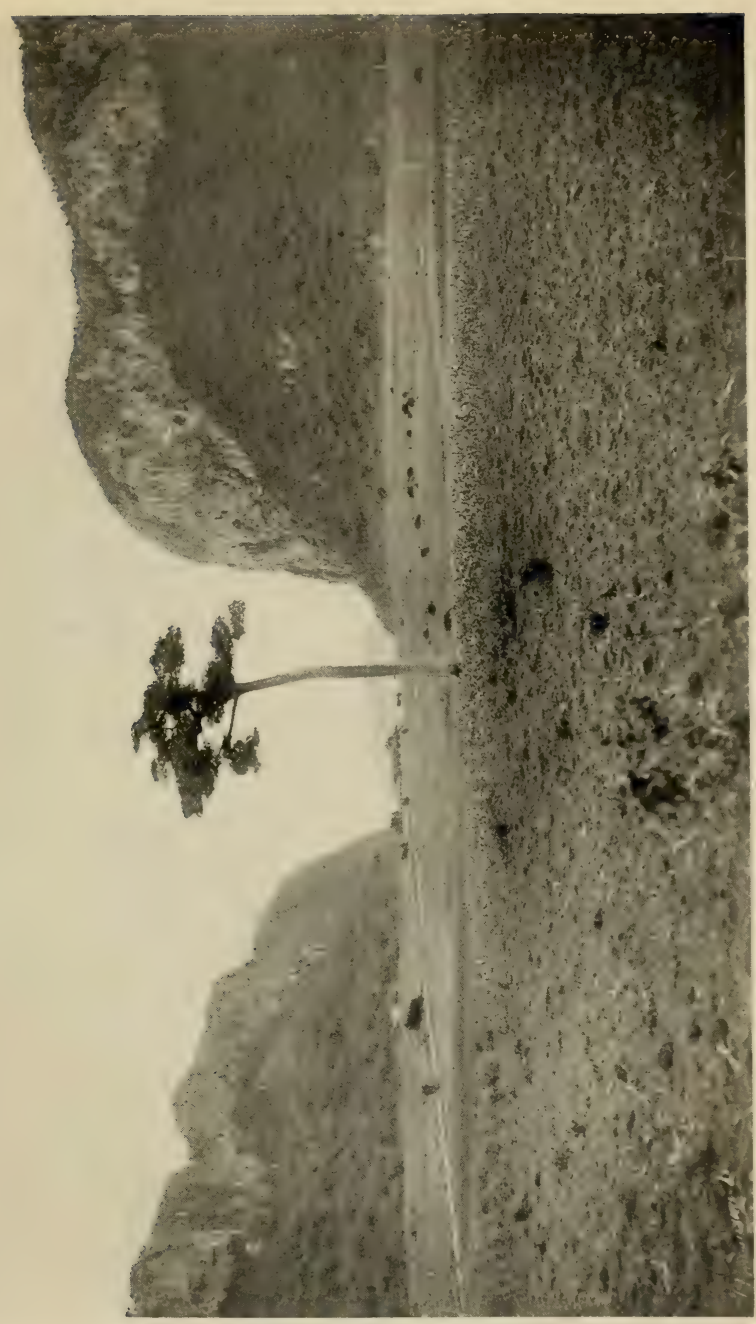

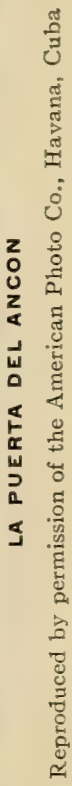



obvious justice was not to be allowed. Once on the floor, a cat leaped upon the meat and two dogs leaped upon the cat. In the mêlée the steak disappeared beyond any possible recovery by the original thief-all of which shows how little equity there is in this world.

At the cave we found the river too full for exploration, especially within the darkness of its tunnel, so we decided upon a good swim in the cold water. Having undressed, we stood about a la September Morn, hesitating a moment to plunge, when someone reported a snake in the water; then another noted two more snakes, and upon closer examination we found the river to be full of them. They seemed, however, to be very friendly and confidential, showing no fear of us, nor hostility, but their presence in the water dampened our ardor for the bath. They were less than a yard long, dark brown, spotted, and with long heads. It is a very common water snake of Cuba that frequents stony rivers and is generally known to Cubans as the cativo (Tretanorhinus variabilis). It is confined to the island and is the only Antillean species of a Central American and Panamic genus. I have never observed 
the cativo during the winter months. We took our bath but with a prodigious amount of splashing.

A notable catch was made here of the exceedingly rare Chondropoma vinalensis which we regarded as one of the real molluscan prizes of the expedition.

Once again we sat under the great mimosa tree by the side of the carretera opposite Señora Piad's house, awaiting the regular motor diligencia for Esperanza, and chatted with the local schoolmaster who has the curious conceit of dressing his boys in feminine furbelows and the little girls in more masculine severity of attire. Mounting the big motor-bus we bowled noisily around the eastern end of the Costanera, passing close under its superb cliffs and then across the gloomy pine lomas to Esperanza on the coast.

On the goleta, we found the Patron and Lesmes absent, and we were informed that our tree ducks had escaped; the Patron, aided by Lesmes, was in hot pursuit. What a hopeless quest! At 9 o'clock that evening they returned worn out but triumphant in the possession of three tiny little wood-duck chicks, captured miles away at the cost of a journey through the wilds of an almost 


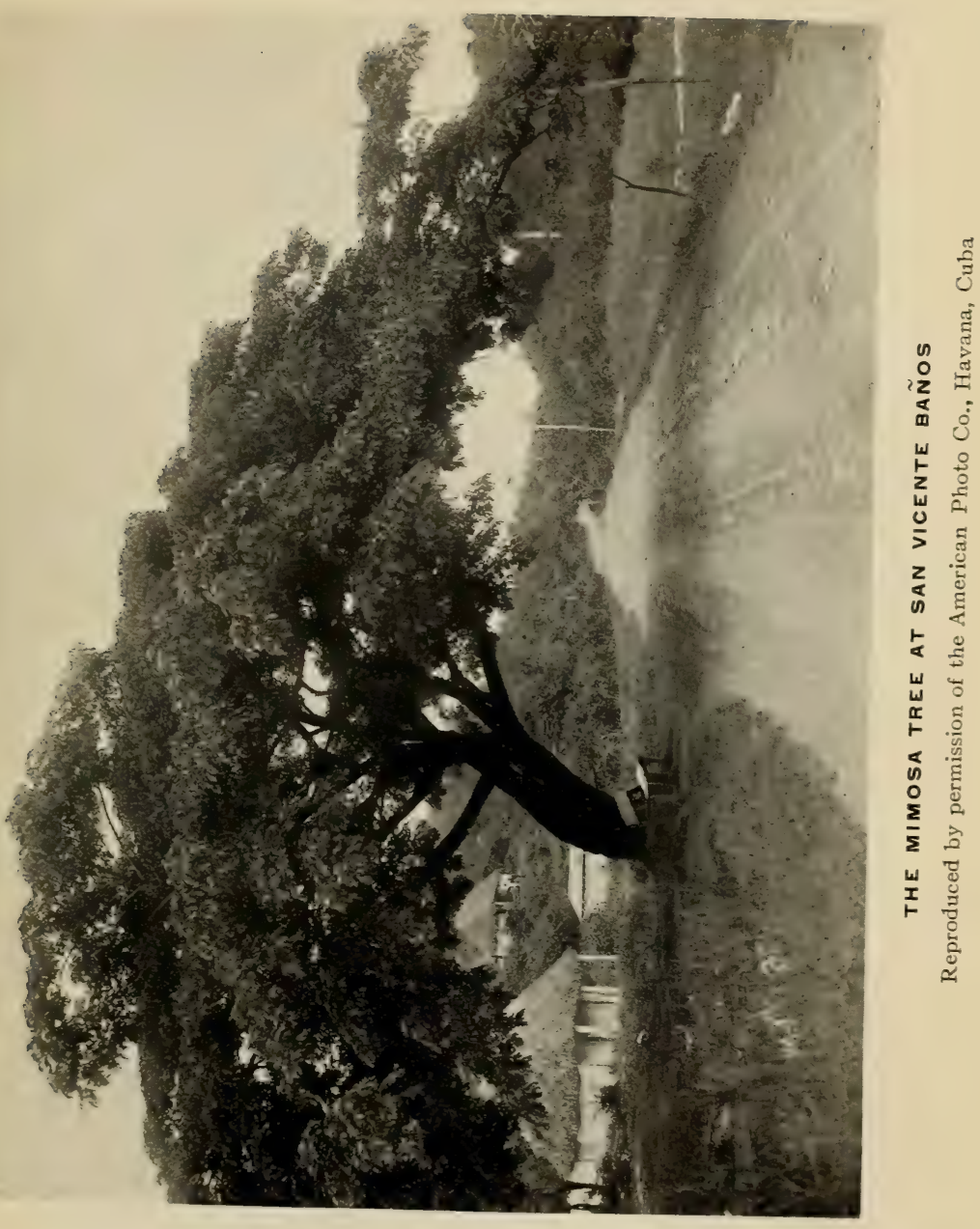



uninhabited country. The escape of the tree ducks (through no fault of his own) had determined the Patron, at once, to make good the loss. The incident showed his fine sense of responsibility.

A glorious night of rare beauty tempted us to neglect sleep. There is nothing in the world so lovely as a still cloudless tropic night on the water. Any description becomes a mere juggling of words that at last conveys only some physical facts which may be compressed into a tabloid form of agreeable temperature and bright stars. What really makes it so fine is the hypnotic effect upon man himself, who, exalted by its poetic charm, gives it the additional qualities which the irreverent call "soul-stuff." 


\section{CHAPTER XX}

\section{Esperanza to Cayo Levisa}

Tuesday, June 2d. Proceeding east from La Esperanza, the fairway between the mainland and the reef is less wide. The reef draws in closer to the shore as the island shelf narrows. Various groups of islands, sometimes with mangrove fringes, are of the same type of formation as are the sand-bars and shoals observed farther to the west, but most of them have sufficient area of dry land to support a considerable amount of vegetation other than merely of a salt marsh nature. The main shore line is also bolder, thus affording a welcome change from the mangrove and buttonwood swamps that are so monotonous a feature of the littoral to the westward.

An early start in the schooner availed us but little, for the air and the glassy surface of the water were still as in the heart of the doldrums. The bottom at about fifteen feet actually seemed too near to make safe a dive from the deck. Our 250 
time, however, was not lost by delay in getting under way, for a few hours of just such quiet conditions were much needed to prepare and pack the catch of the last three days, and a dredging party in the launch improved the opportunity to survey the bottom and select likely looking spots for several excellent hauls. When the first morning puffs of the trade came along we stood out of the bay, rounded Punta Lavanderas, and headed to the east, gathering headway as the trade finally settled down to a steady breeze. The greater number of islands encountered and the closeness of the reef forced the schooner into ever-narrowing passages where the decreasing depth scarcely permitted us to pass. The soft bottom of the narrow fairway is streaked by grooves cut by the keels of fishing craft. Several times we stuck, but skilful jockeying freed us, and we crept on. For a mile or more the legs of our tacks were shortened to fifty feet and the bowsprit grazed the trees as we came about.

A 3 o'clock in the afternoon, having reached a point under the Levisa Keys and opposite a pass through the reef of same name, the Patron announced that the schooner could proceed inside 
no farther. From here on, then, the route to Bahia Honda must be by blue water, as this was the last of the passes that could be safely negotiated by the Barrera. As it was impossible, therefore, to reach the little harbor of La Mulata (our starting point for the Pan de Guajaibon) by the schooner, the only way left for the shore party, who wished to visit the big mountain, was to proceed to $\mathrm{La}$ Mulata in one of the smaller boats. We calculated it to be about twelve miles from our position to Mulata Bay and thence about seventeen more to Bahia Honda. As we knew nothing of Mulata, we decided to await the morrow and by making an early start in the auxiliary we would be enabled to investigate, with a full day ahead, all the possibilities of food and shelter at Mulata, and the means, if any, of attaining Guajaibon. In case of failure, we could at once proceed on, hugging the shore line and feeling our way across the reef and rejoin the schooner in the safe haven of Bahia Honda before night should overtake us.

Having decided on this program, the auxiliary was selected with Luis and Pablo as crew. Provisions and water for several days were put aboard 


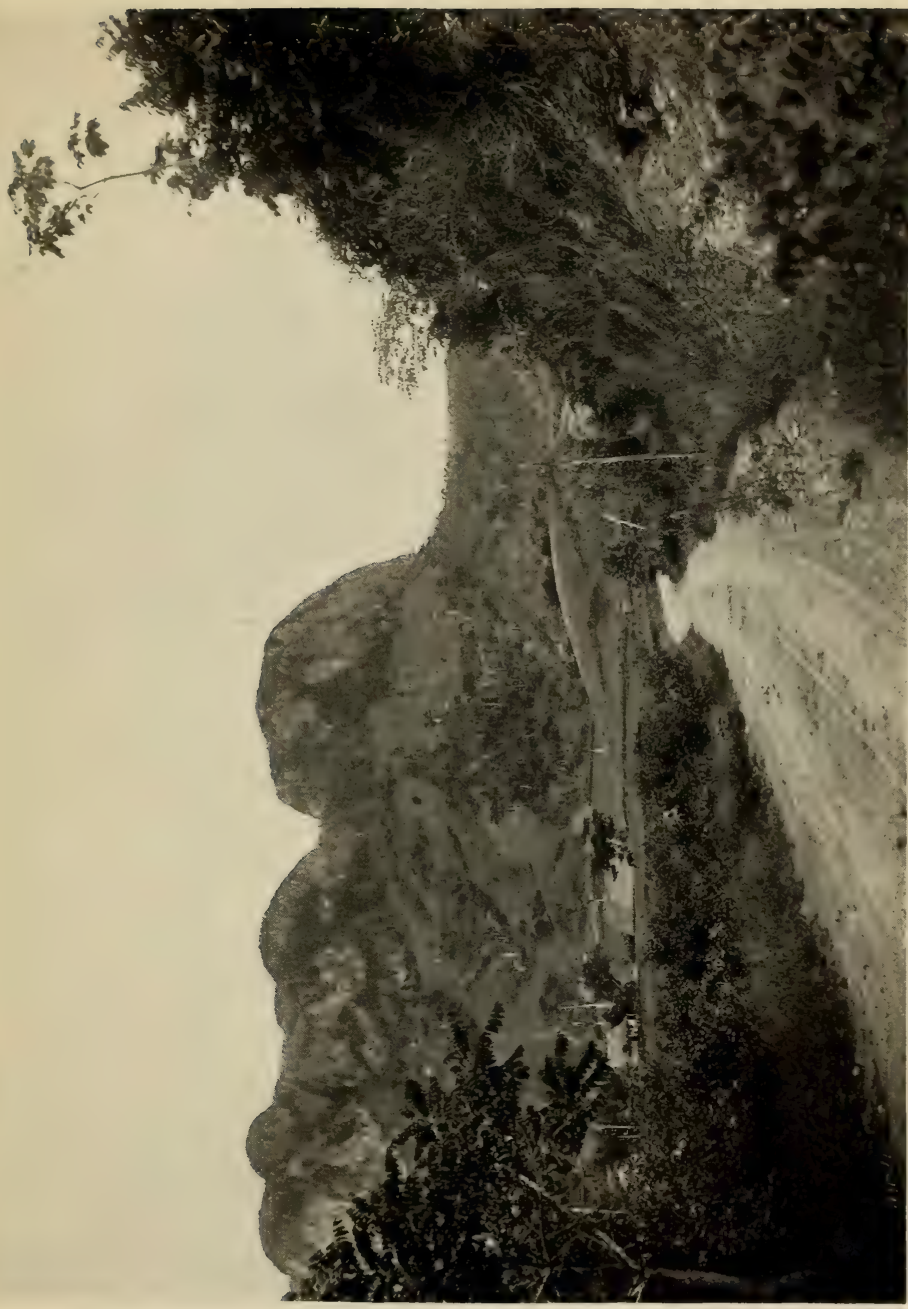

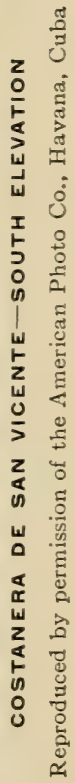



and a full tank of gasolene, giving us a power radius of about one hundred miles.

The sierra, from our new view-point, presented an inspiring sight. The great Pan de Guajaibon, with its three peaks, now seemed to be very near and it dominated all other surrounding heights. Through a gap, in the northern series of high elevations, we could distinguish a confused mass of mountains. One of the highest of these, far to the south, we decided must be the Sierra de Guira, which rises well above the other mountains in the neighborhood of San Diego de los Baños. La Guira belongs to the southern range of the Organos and is a part of the system that encloses Rangel. It is one of the greater mountains seen from the car windows of the railway to Pinar. Between Guira, to the south, and Guajaibon, to the north, is a rough region of complicated mountain structure, imperfectly known to the mapmakers, and it is a country of much interest to both biologist and geologist. Having no roads beyond the merest trails and but few habitations, it is not an easy region to explore.

Our present interest, however, was sharply focused upon Guajaibon. In previous trips to 
western Cuba, this mountain had always been a hoped-for attainment, but, for one cause or another, none of us had ever reached its base. Approaches are difficult from every direction and tediously long except from the north. Even from the north, its approach is well guarded, for the Bay of Mulata, its nearest coast point, is difficult of reach from anywhere.

Guajaibon has twice been visited by collecting naturalists-the plodding Gundlach and the rapid traveler, Morelet. Fifty years ago Gundlach touched the mountain base at two points and took away a wealth of booty that has made the locality stand forth like an exclamation point in the published faunal and floral lists of Cuba. In our imaginations the place had assumed an especial importance-a naturalist's paradise of rich abundance. A year before, Simpson and I were scrambling about the paredones of Guira and talking of Guajaibon, when our guide pointed to a hazy peak of bluish purple far to the north and remarked, "that's it," and we fell silent-even on rich, splendid Guira.

Now, at last, we were upon the very threshold and about to enter our delectable coun- 
try, if we could but find the route from the coast.

The afternoon was spent in an examination of the Levisa Keys and the reef without. Although a very light sea was running, it was, nevertheless, too strong to permit venturing upon the coral patches-especially as diademas were very abundant. A number of hauls of the dredge were made among the sandy patches in and about the reef which proved very profitable. 


\section{CHAPTER XXI}

\section{La Mulata}

Wednesday, June 3d. At 6.30 A.M. the shore party, Bartsch, Clapp, Rodriguez, and myself, boarded the auxiliary, amid furious barking of the two dogs and a volley of adios from the crew. The schooner at once hoisting anchor drew away, and we, in the little boat, proceeded on our course in the opposite direction toward the Alacranes Keys just discernible on the eastern horizon. Before going very far, one of the cylinders of our engine "lay down" and refused to "get up." Without Greenlaw, who is a wizard with engines and speaks their language, we felt very helpless. Everyone, in turn, "got out and got under," and did all that seemed possible to do to any engine. When hope was about dead and we sat bathed in gloom the balking cylinder suddenly started and worked perfectly, and then we forged ahead through the clear water in a most satisfactory manner. Without charts or knowledge of the 
waters, we had some apprehension lest we miss our mark. Taking a course outside the Alacranes Keys we continued until the last one was passed and then turned directly in toward the mainland coast. Here we discovered a wide open bay of deep water, with shores wooded to the edge but with no sign of habitations. Skirting the circular shore line to locate any evidences of an opening into the forest we finally decided upon landing for a reconnaissance where some rocks projected into the bay. Here, to our delight, we discovered a path leading back through a semi-open country with patches of timber. Following this for about a half-mile we suddenly came upon a tienda, or little country store, of the most primitive kind. It was the only habitation in sight in the midst of a fine-looking country. The keeper of the tienda is a large, efficient-looking man of few words. $\mathrm{He}$ looked us over in solemn silence and appeared to gather an unfavorable impression. When we had explained our raison d'être and our aspirations for Guajaibon, he decided, though apparently against his better judgment, to have dealings with us and even to aid and abet us in the accomplishment of our object. Accordingly we were promised nour- 
ishment, beds, horses, and a guide, at which announcement we could have shouted for joy and embraced our sphinx-like host. After all our doubts and misgivings this, then, was really the "town" of La Mulata, the gate to Guajaibon, and the way was open. From the tienda the mountain looked not two miles away, magnificent in its precipitous northern face and great height. We were for leaving our equipment and making a dash directly for it, but the man of the tienda advised patience and horses. To our distress we had to wait. A man would arrive later, he said, who would look after the details and it might be better to wait for him.

Within the tienda was an unfloored room, hung about with sheaves of fodder, onions, garlic, corn, and sundry leather articles connected with harnesses and saddles. At one side was a counter, behind which were some shelves bare of any stock in trade. Upon the counter were a pair of scales, a pile of wrapping paper, and some cord of vegetable fiber for securing packages, all of which seemed needless, when there was no one to buy and nothing to sell. In the ceiling were festoons of webs among which lurked large hairy spiders, and 
sundry rustlings in corners and among the sheaves of fodder aroused thoughts. A swarm of chickens, mongrel dogs, and pigs, passed in and out of the wide open doors. Every few minutes there was a general clearing out of these intruders by the proprietor, but the task once accomplished, the chickens flocked back with the assurance of at least a few minutes' leeway before another attack.

Later on a handsome young man, bearing a Winchester rifle, dashed up to the door upon a spirited horse and dismounted. With rakish air he swept in, glanced at us without sign of interest, and went into executive session with the proprietor. This conference concluded, the young Lochinvar approached us with quiet reserve and dignity of manner. He would get horses and serve us as guide, but the earliest possible start would be the following morning. He must find horses from the country around about, and saddles would be hard to secure for so many, but it could be done. "Adios, gentlemen"; and, like a projectile, he was off upon his pony. Here was a new genus homo indeed.

In the hope of utilizing, to best advantage, the day of enforced waiting, we struck off for the San Marcos River, inland a half-mile distant. The 
country along the river is exceedingly beautiful. Although the soil is of the sandstone type it must contain some admixture of the limestone clays, for the vegetation is superb and of the rich soil kind. Splendid clumps of bamboos wave their feathery plumes over the river, and fine large trees of dark heavy foliage adorn the landscape. Groves of the finest royal palms yet observed, even rivaling those of the Yumuri, add their own peculiar charm to the scene. Flowering shrubs of many kinds, now in full bloom, scattered dashes of bright red and yellow or pink over the earth. We asked ourselves, why is not this splendid country settled and cultivated? With the exception of the tienda and one other house later discovered-the house of our young Lochinvar-there was not a habitation within miles. Lack of communication alone can account for it. Some day when the railroad will be extended from Guanajay, through Bahia Honda to Esperanza, traversing this lovely country, it will become another of Cuba's garden spots - like Viñales, the Yumuri, and Mayari in the east. In the river we captured some crustaceans and melanians and about its banks a few insects, a snake, some lizards, and butterflies. We had not 
been there nearly long enough when a storm of great severity made up about the summit of Guajaibon; with ominous flash and peals of thunder it headed for the coast driving us to shelter in the tienda. When, with distant rumblings, the storm finally passed, the heavy rain clouds disappeared, revealing again the big mountain. A setting sun tinted the dissolving mists with a flush of rose, and the Pan, growing somber in the fading light, took on a deep purplish cast, seeming to actually expand and approach us as darkness crept on. Soon brilliant stars flashed from a cloudless sky, lesser ones gradually filling in the spaces, and the Milky Way glowed like filigreed silver. Fireflies began swinging their bluish-green lanterns in silent signal to each other. Some tree toads called with belllike sound. A herd of cattle drew near to lie upon the ground, close to the tienda, and their audible breathing was the last sound heard as we drowsily turned in upon some cots placed on the salesroom floor. The proprietor barred the doors securely against the fourteenth-century bandits of Spain, and carrying out our only light, a tallow dip, bolted the door into his own apartment. $\mathrm{He}$ took no chances. 


\section{CHAPTER XXII}

\section{Pan de Guajaibon}

Thursday, June 4th. At a very early hour our host entered the shoproom where we slept and opened the doors to the fresh morning air and to the chickens that immediately swarmed in. Eager to get started on our journey we hurriedly laced on our leggings and repacked the canvas saddle-bag containing all we possessed. At six, our young Lochinvar, whose real name is Francisco Gomez, or "Pancho," for short, arrived with four rather tiredlooking little horses that he had gathered the day before from far and near. Their saddles were of great antiquity, with practically all straps broken and mended with pieces of string. The bridles were a composite of leather remnants, rope, clothes-line, and string. The stirrups had all suffered operations of some sort and were bandaged with wire. Pancho smiled faintly as we inspected the outfit and appeared to enjoy the situation. Thus equipped we set forth much like four Sancho Panzas in 


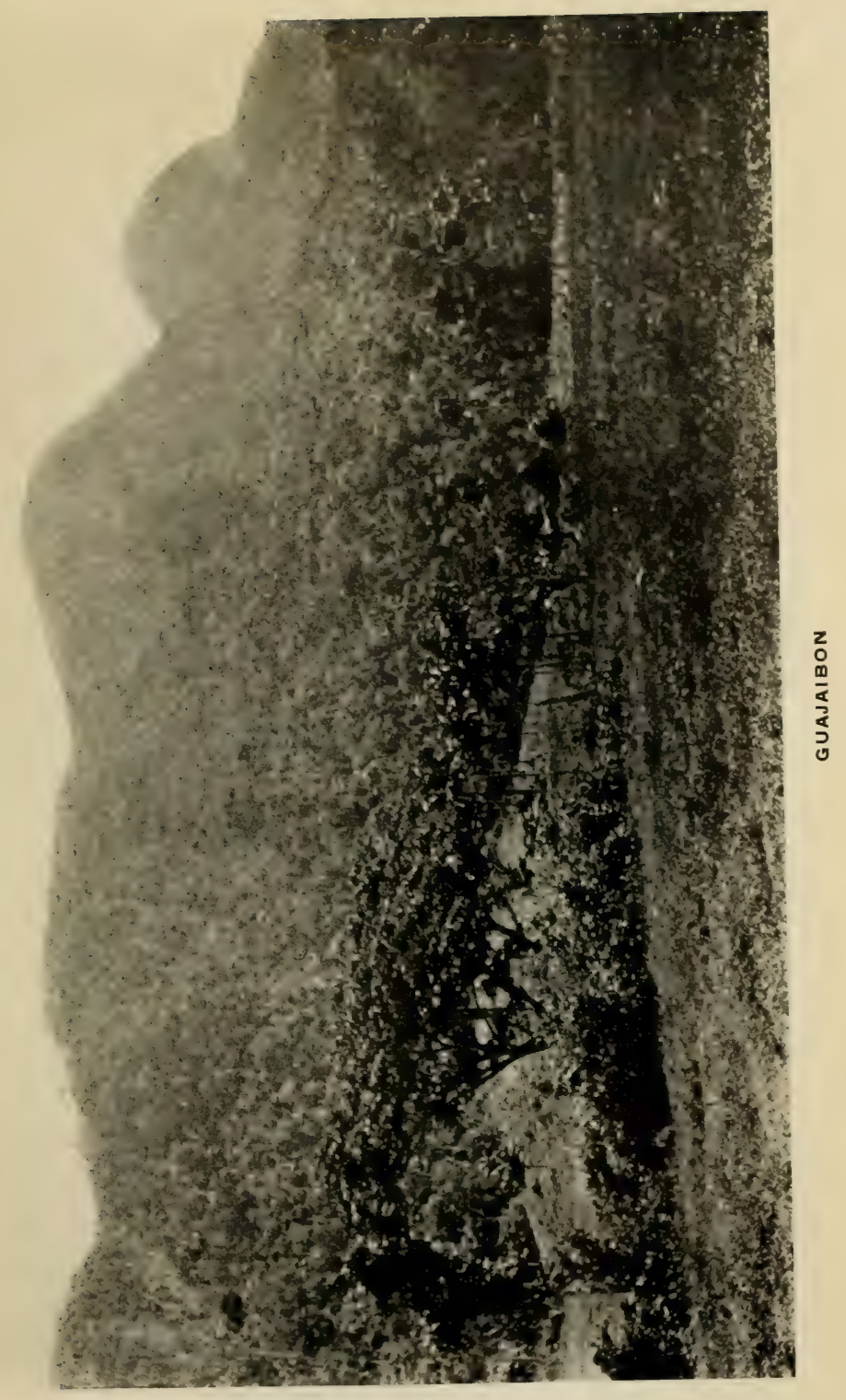



attendance upon Pancho who, finely mounted, led the way, with a Winchester across the saddle and three deerhounds in leash following eagerly by his side.

Owing to high water in the San Marcos River, the more direct route to the Pan was impracticable, and a longer one to the westward had to be taken -one that followed along the steep sides of a very high pine loma and finally crossed the river much farther up where the flood would likely be less. The route we were obliged to choose imposed upon us a ride long to be remembered. The high loma of quite fifteen hundred feet altitude presents a deeply furrowed eastern face and is two or three miles to the west of the direct route between Mulata and the Pan. It seemed almost wicked to have to follow a path that not only took us miles out of our way, but compelled us. also to accept added difficulties of travel. All went well enough as we passed through the lowland country, but the loma once reached our troubles began. This loma is of sandstone and shales, upon a serpentine foundation. It supports the usual scant coniferous forest, but it differs from other lomas theretofore seen in its exceedingly abundant vegetation, 
particularly in the arroyos (ravines) where the floral condition almost approximates that of the sierra in richness. The path is mercilessly rough and steep. Our sudden and precipitous descents down the rocky sides of arroyos, our flounderings through the boulder-strewn beds of mountain torrents, and our equally steep scrambles up the opposite sides, repeated again and again through countless arroyos, got on our nerves. Saddles turned, girths parted, bridles snapped, and stirrups fell off, necessitating many stops for repairs, all to the satisfaction of the horses, however, that seemed thankful for every accident.

Between the arroyos, the path winds along the steep sides of the loma tending always to work upwards, and the recent rains had made the trail very slippery. To make matters worse, our course appeared to take us no nearer the Pan, but threatened, on the contrary, to convey us quite around and beyond our goal and then, after traversing all the mountain ranges of Cuba, to drop us finally into the Caribbean. Pancho was slyly amused at our annoyance, but he kept up our courage by occasional mention of the fact that the path would soon turn in the right direction and we should 
cease boxing the compass and head directly for our destination, which at last it did. We made a final sharp descent into a rain-soaked valley of limestone soil-a perfect quagmire of slippery clay, traversed by many streams feeding into the San Marcos. Fording many of these as well as the larger river itself, we swung at last into the finca of San Juan de Sagua, a tobacco estate, situated at the western end of the Pan and close under the foot of a southwestern spur of the big mountain. Guajaibon at last!

The tobacco plantation of San Juan de Sagua is a very old estate. The owners have cultivated the rich valley lying within a "bay" formed by an insweeping curve of the "shore line" into the western end of the Pan. The mountain rises everywhere precipitately from its base and is densely forested. The valley portion, occupied by the finca, having been reclaimed from the wild state, is now a series of open fields bordered by royal palms and patches of exceedingly dense growth. There is a central house of some pretension, a barn, a large drying shed of semi-open construction with high palm-thatched roof, and scattered about within the palm groves are a 
number of hohios of the natives, who attend the crops.

The complete isolation of the finca, planted in this wild region amid towering peaks and heavy forest, has reacted badly upon its residents who live so very close to nature. Knowing almost nothing of the outside world, they are primitive to an astonishing degree. The effect of isolation in a wilderness has either a degenerating or an improving effect, according to personality. The pioneers of our own country, who left their eastern homes to found an empire in the forests and prairies, expanded and grew. Whatever of roughness or even eccentricity of manner or speech they may have acquired, when long removed from the leveling influences of civilization, they did not, in any sense, become degenerate. They were adventuresome spirits to whom the idea of conquering the wilderness made strong appeal, and they found in the wilds the very elements best suited and adapted to their well-being and they developed into a strong and virile people. Those, however, who through force of circumstances and with no love of the wilderness itself, find themselves exiled away from communities of their own kind, tend 


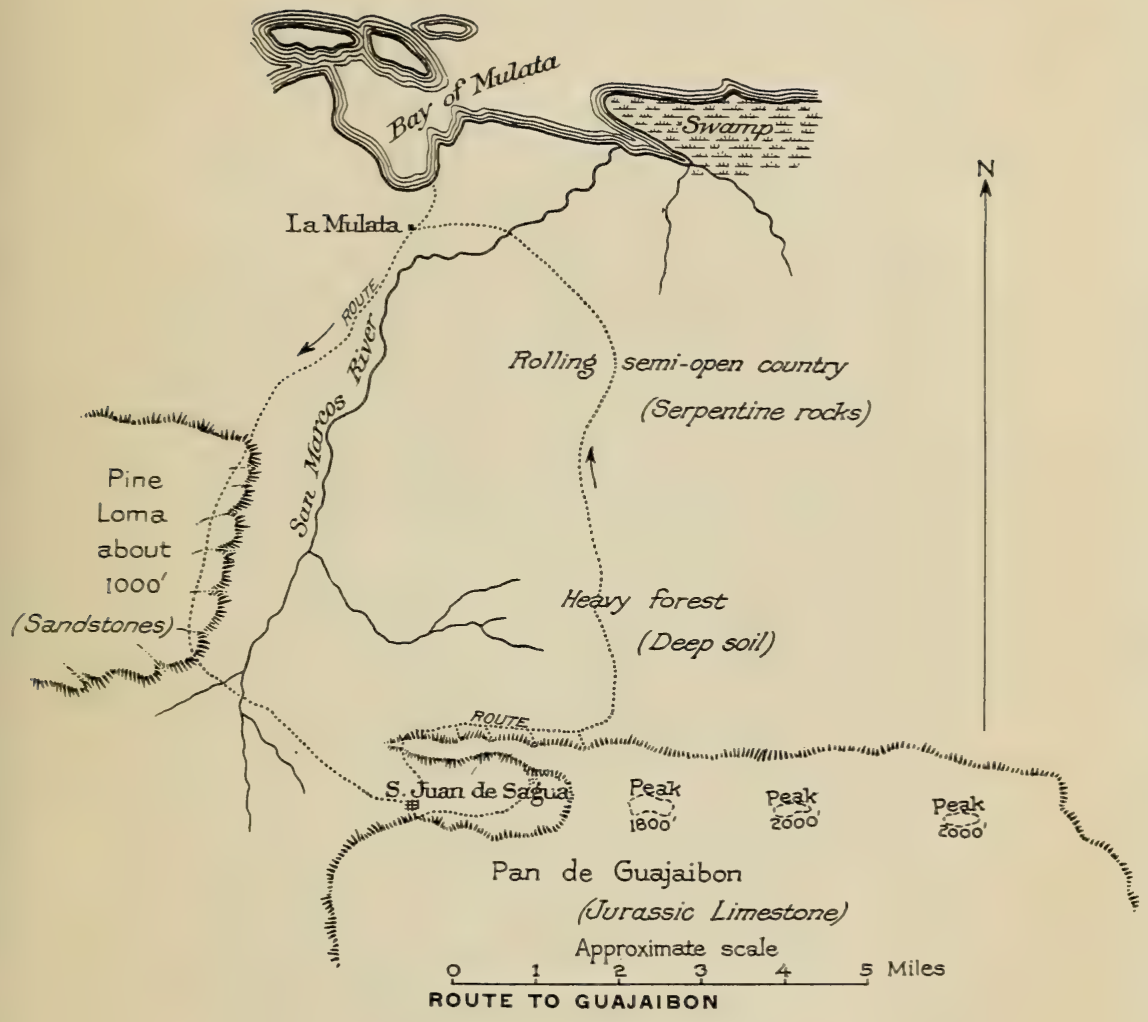



to revert backward, just as do well-bred domestic animals when left to shift for themselves. We had noticed that among the Cubans, who live in remote places, physical degeneracy was by no means the rule. The lesser average size of the people is a racial characteristic and can hardly be accepted as a sign of degeneracy, a smaller stature not necessarily impairing the vigor of the race.

The proprietor of the finca, who was now to become our host, is a dark sinister-looking man with large bristling mustache. He is of the type that we have conventionalized in illustration as the man who broods and foments revolutions. Probably our host did neither, but merely looked the part. The women about the place smoked huge plantation cigars, screamed at their children, and created about them an atmosphere of perpetual turmoil and fussy inefficiency. The youth of the ranch exhibited marked signs of degeneracy in overly large heads, mature faces, and dull perceptions. As a rule, the Cuban children we met showed a lively interest in our pursuits and were keen to aid us in view of financial prospects ahead. They measure as well in intelligence as do children of similar age in any country. The little boys and 
girls of this ranch, however, seemed very apathetic and dull, and they were wholly incapable of sensing a situation of probable advantage to themselves. While our stock of Spanish words was limited, we nevertheless could get on quite well with whomsoever we encountered, even essaying at times little pleasantries. As long as we flew low we had no serious accidents, but here our linguistic accomplishments utterly failed. With our host alone could we converse, and with no one else. About the main house a swarm of domestic animals prowled about in search of food. Green parrots squawked, roosters crowed, turkeys gobbled, dogs barked, pigs grunted, and above the animal chorus arose always the cries of the womenfolk directed at the children. These sprawled about, fell off chairs or steps, and howled at the slightest provocation. Some peculiar-looking farm hands hung about sullenly watching us, giving us the somewhat unpleasant feelings of a visitor to the dangerous ward of an insane asylum.

The scenery about the finca is fine, although too shut in by dominating heights and heavy forest to be wholly pleasing. Nature here seemed almost overpowering. The mountain gave a 
curious impression as if about to slide down upon the vega and bury it under a mass of white boulders. The forest, relentlessly powerful by virtue of a soil, rich as chocolate and wet with daily rains, seemed to threaten a stealthy advance, and an irresistible engulfment of the finca and its people.

Soon after our arrival a small deer appeared in the open, quite near the house, and the greatest excitement ensued. Pancho seized his rifle and started after, followed by the male population of the ranch and all the dogs. Many shots were fired that viciously echoed back and forth among the encircling mountains, but the deer escaped. This is a sub-species of the American deer (Odocoileus virginianus) imported into $\mathrm{Cuba}$ from some unknown place and which has become quite abundant in the pine loma country of Pinar del Rio and in other wild parts of the island.

Pan de Guajaibon is the highest of the Organos Mountains and hence the greatest elevation of western Cuba. The exact altitude is not definitely known but is usually given as about 2500 to 3000 feet, with the base but little above sea level. It is a sierra of limestone formation, probably Jurassic or Cretaceous, and lies a little to the north of 
the true axis of the Organ Mountains, and therefore stands in partial isolation. On the south side, it is connected by lower ridges and spurs with a maze of mountain heights, the alignments and relations of which are not yet correctly mapped out. On the north side it presents to the sea (eight or ten miles away) an uninterrupted front of about five miles of precipitous densely wooded surface. Its summit is marked by three peaks of nearly equal elevation. As there are no considerable heights directly between the mountain and the sea, the full majesty of Guajaibon is thrust upon the observer who sees the mountain practically from its base to the top. This gives to Guajaibon a very massive appearance even beyond that of other individual mountains of the province, though in reality it is no greater than many others except in a few feet of altitude. Viewed from quite near it is no more impressive than is the Costanera de San Vicente (back of Esperanza), for it has not the latter's magnificent vertical walls, but the mountain is considerably higher.

Faunally, Guajaibon is of great interest on account of its partial isolation. The richness of both fauna and flora is, in a measure, accounted 
for by the fact that its rock is but little altered and crystallized by metamorphic processes and is therefore softer and more easily decomposed. It is also likely that its position and height bring to it a greater yearly percentage of moisture. Whatever the true causes may be, the Pan and the country immediately about offer a wealth of animal and vegetable life in excess of any other locality we had seen.

The coffee and chicken-with-rice function was very quickly concluded, and we fairly bolted for the nearest mountain side, just back of the house, some hundred yards away. Pushing through the dense tangle about the base we began a slow ascent of the confused piles of limestone blocks, all buried in forest growth and dripping with moisture. The delights of getting into a region of land-shells new to our collecting were very great, and especially when they were so abundant and active. Besides a wealth of insect life, we found an unusual abundance of batrachians chiefly represented by Hyla or tree toads, of several exceedingly interesting species. One of these of truly stentorian voice for so small a toad is the Eleutherodactylus auriculatus. This little fellow, of loud voice and long name, we 
could only collect by most intensive work, although there must have been many about us upon the trees and shrubs judging from the chorus they persistently kept up. Such species of tree toads as live only upon the mountain side of the sierra must have difficulty in finding water in which to lay their eggs and to shelter their young during the tadpole stage. Standing water is impossible in such stations. We do not know from actual observation that this species lays its eggs in the little water-filled hollows of the bromeliads but such is most likely the case. One or two species of this same genus found in the lesser Antilles are known to do this, and what is more interesting still is the fact that by an adaptation to circumstances the tadpole metamorphosis of these toads is entirely passed in the egg, thus requiring no permanent water station. Our little tree toad here very likely has acquired the same life habit.

Not more than one hour could be given this station according to our careful allotment of time. Feeling that we had scarcely more than glanced at the place, we reluctantly left to proceed across the vega to the western end of the main mountain, 
choosing there for attack a spot on the south side where a small paredon gave indication of a good locality. This paredon begins at a height of about two hundred feet, the rocky talus below being very densely wooded. Our host with some men carrying machetes accompanied us to this place and greatly facilitated our ascent by cutting a path through the jungle. At this spot the richness of animal life was found to be even greater than upon the mountain side nearer the ranch house. We worked feverishly in a drizzling rain seeking to gather a representative collection of the fauna. Victor and Pancho, in search of bats, entered a narrow opening into a cave, from the chamber of which the muffled sound of shots could be heard. So abundant was the life of the place, now in its fullest seasonal activity, that we could hardly focus attention upon any one thing. Tree toads chirruped and rang out their bell-like calls from all sides; myriopods, including some small Iulus, were about in great quantities, while the rocks and trees fairly swarmed with mollusks. None of us had ever seen such profusion of life. It was to the land-shells we devoted most attention, not only because we had a weakness in that I8 
direction but because the species were mostly new to our collecting.

One of the striking forms always in evidencewas the giant Cuban slug (Vaginula occidentalis) which to our unaccustomed sight appeared to be an impossible creature. The largest slug we had ever seen is the common garden Limax from Europe and the Northern States (L. maximus), a large example of which measures in size about one's middle finger. This herculean slug is as large as a man's hand. Its effective mode of protection lies in a sticky mucus which it exudes when irritated, otherwise so tempting a morsel of flesh would soon be appropriated by birds or harassed by the predatory ants that abound in such forest station. Unlike most mollusks, the slugs have no shell into which they may withdraw at an enemy's approach. They have no teeth with which to bite nor legs with which to run, but nature has endowed them with an even better defense, and they thrive in the midst of a world of predatory creatures.

The struggle for existence in so favored a spot is very keen. Those creatures that peacefully browse upon the vegetation and entertain no hos- 
tile designs upon other living things must possess highly specialized methods of defense, like our slug, for no skill in hiding or no scheme of protective coloration could wholly save them from the active swarms of carnivorous insects and myriopods that range over the ground and upon rocks and vegetation. Vast quantities of mollusks, notwithstanding their shelly fortress, fall victims to birds and mice and to other carnivorous mollusks, but just why certain species, conspicuous through lack of protective coloration, do not suffer a like fate, is not altogether clear. Upon this particular paredon are two species of mollusks (Eurocoptis blainiana and Chondropoma sinuata) living more or less in colonies and readily to be seen by reason of their contrasting color with the white limestone. Neither of these appears to be preyed upon by birds, and that they are exempt from attack by other larger enemies is equally certain. The only explanation would seem to be that they are distasteful as food either on account of some acrid flavor or poisonous quality. A most striking example of this immunity is furnished by the very beautiful arboreal snails, Polymita picta of eastern Cuba, which are most conspicuous ob- 
jects upon trees and shrubs, their bright yellow polished surface causing them to appear at a short distance like flowers. Did they not possess some disagreeable quality as food, they certainly could not survive in their present exposed mode of life. Other species of land mollusks inhabiting the same general locality are forced to keep in hiding during the daylight hours to escape the attacks of birds that feed ravenously upon them. The fact that all land mollusks lay eggs profusely would indicate a high mortality from natural enemies.

Despite the vast quantity of individual specimens of land-shells found here, the actual number of species is not great, probably not over twenty or twenty-five inclusive of the minute forms. This might be considered high for an equal area in a northern climate but it can hardly be compared with the astonishing number of species to be encountered in certain Jamaican localities. In one "cockpit" of an area less than ten acres, two of us had once taken seventy species of land mollusks, and upon another occasion a locality of about an acre near Savanna la Mar in Jamaica netted us the extraordinary total of eighty species. But these shells were of the greatest interest to us. 
Several of them represented forms described by Morelet who, in a hasty visit to Guajaibon, seems not to have taken many specimens, and hence his species are usually rare and little known. Gundlach did more to distribute specimens from the Pan, but neither are his very abundant in collections.

Our progress was finally stopped by suddenly finding ourselves upon the edge of a precipiceone of those jumping-off places of the sierras, so completely veiled in foliage as to be unseen and unsuspected until about ready to fall over it. While seeking a way out, we were startled into a realization that night was almost upon us. Our host and Pancho had returned so we beat as hasty a retreat as the tangled jungle would permit. Nothing is so trying to one's equanimity as an attempted dash through a tropic jungle. The slender stems of innumerable vines have a diabolical way of entwining themselves about one's legs and arms, or lifting off one's hat, as though possessed with a playful intelligence. Darkness falls with great rapidity, and to be caught on the mountains without a light would mean a night spent in the woods. Such an idea might be even 
agreeable in a northern forest where one could gather the materials for a camp-fire and lie in security upon the ground.

We arrived at the house of the finca well done up with the heat and wet but thoroughly satisfied with the day's accomplishment. Our host led us to sleeping quarters in the tobacco-drying barn where in company with a number of the reticent farm-hands, we stretched out for the night upon some cots.

Friday, June 5th. At five, our party awoke refreshed and ready for another day's strenuous campaign. Herein lies ample evidence that vigorous outdoor exercise, combined with mental exhilaration, furnishes a panacea for most ills. A body normally prepared for sleep requires neither springs nor mattress. The term "hygienic surroundings " could hardly apply here, and the science of dietetics with its nice proportions of proteids, carbohydrates, and its measures of calories could receive but little consideration. Such things seemed necessary rather to the cities and their dwellers, where only mental effort counts and machinery does away with physical exercise, where sunlight and air are too expensive for general use. 
It is there that the competitive struggle for life, sustained upon adulterated foods and many stimulants, reduces man to a very real necessity for constant attention to his weakening organs. Under such artificial conditions of life everyone's standing army of leucocytes becomes disorganized and inefficient, and humanity's war against its greatest foe, the disease germs, must be fought with ever newly devised weapons. Hence the importance today of antisepsis, the tons of carbolic acid, the throat gargles, and serums. Our natural defenses are becoming worn out. Although nature continues as always to preserve the fit, science must now strive harder and harder to keep alive the unfit.

As we emerged from the tobacco barn, clouds of mist rolled down the sides of Guajaibon, gradually dissipating as the rising sun gathered force. Soon came a little breeze, and we spread out our arms to extend our damp clothes to the wind, as do the buzzards their wings. The morning coffee function, amid the hungry animals, was shortened to the minimum of time, so eager were we to resume our work. Once aboard our sleepy ponies we took the shorter route to the coast, making directly through the lowland forest for La Mulata. This 
is the route that necessitates crossing the San Marcos in its lower reach. Unless the day should prove fine we had been duly warned of difficulties in fording that already swollen stream.

Leaving the finca house our path first led us across the savanna to the extreme western end of the Pan; thence turning east it follows closely the northern base of the mountain, a distance of about two or three miles. This is a heavily forested region. The character of these woods differs markedly from any yet observed. Striking features are the great number of trees bearing flowers of vivid red (suggesting a species of Poinciana), the prevalence of flowering shrubs, also the extensive areas of rose-apple (Eugenia vulgaris) now in ripe fruit. The mountain can only be approached through exceedingly dense jungle, save in a few spots where tobacco clearings have been extended to the actual base. We availed ourselves of all these openings. Along the entire northern front the mountain is almost perpendicular to a height of several hundred feet and thence very steep to its summit. The extreme western end is dwarfed into a sharp ridge of less inclination and height, and there we made our first raid. We 
were exceedingly fortunate in the choice of this place, for not only did we find there nearly all the land-shells of the Guajaibon list that had failed us the day before, but we fell upon a veritable convention assembled of tree toads, lizards, insects, and myriopods. The astonishing abundance of such desirable mollusks as Chondropoma latilabre, Annularia pretrei, and Cepolis sagraiana filled us with delight. For this satisfactory abundance we had to thank the rains. To Rodriguez's disgust we saw no snakes, but he recouped in a fine catch of beetles and butterflies.

None of the other places touched along the base offered so good collecting-yet no station was abandoned without some rewards.

Where the path finally leaves the mountain and turns north through the forest we stopped to take our last nearby look at old Guajaibon. In farewell gaze we were impelled to those same reflections that Azucar and the forests of Cape San Antonio had inspired. How insufficient had been our brief visit! If only we could remain longer! Each one said to himself, "I shall return some day," but knowing too well he never would. As we lingered hating to leave, the crashing noise of some 
huge falling boulder reached us. Probably this mass of rock had been poised on high for centuries, perhaps needing only a last drop of rain to dissolve its last atom of support and send it hurtling down, crashing through great trees and dislodging tons of rock and débris to follow it to earth. When a thousand or so generations have passed, Guajaibon will be a little mogote of vine-clad limestone fragments in the midst of a level plain. Confined upon the little irregular mound of white limestone blocks will live an assemblage of creatures, the dwarfed remnant of a once rich life zone. One can easily imagine some bespectacled naturalist prowling about the stones and speculating upon the fauna, so similar to that of another little mogote to the west and so different from that of another one to the south. Our nature student of the distant future will have the advantage of records kept through a brief moment of cosmic time. When all the little mogotes of to-day were great mountains linked into chains and groups and Dr. Torre's fossil sloth, the Myomorthus, browsed upon their slopes, there were no naturalists pottering about to learn and record the facts as they found them. 
With a last good-bye we reluctantly turned our horses into the rose-apple thicket and then entered the forest jungle. Soon a rumble of thunder growled its warning from far away. The air became moist and hot. Every leaf remained motionless, and the oppressive stillness that forebodes an approaching storm fell upon the forest. Our horses plunged and slipped in the muddy path, as they struggled up one ascent and wallowed down another. They splashed into the swollen streams that flowed through tunnels of vegetation. The darkness of the forest grew deeper and the air more suffocating. Perspiration, that would not evaporate into an atmosphere already surcharged with moisture, plastered our clothes to our backs. A flash of lightning suddenly illuminated the forest with a vividness that fairly blinded us and caused the horses to jump with fright. With the resultant crash came a downpour of rain that may be likened to the breaking of a dam. We huddled together, our horses dejectedly standing with lowered heads.

In about two hours we had passed through the belt of heavy woods and emerged upon a partially 
open hilltop, fairly aflame with the same redflowered trees observed near the sierra.

We observed here a striking bird, present all along the coastal region, the Cuban oriole (Icterus hypomelas). It is a black bird with bright yellow shoulders, rump and tail coverts, the under side of the axillaries of the wing is also yellow. As a general alarmist he reminds one strongly of our own cat-bird at home. A little sneaking about the thicket, as ornithologists must do, will lure the oriole from his hiding-place and cause him to scold and revile the intruder. While vociferating he will often approach close enough to permit of excellent camera shots. The Cuban green woodpecker and the white-eyed vireo are also garrulous birds that are often met in company with the oriole. Along the route we saw numbers of small flocks of Cuban parrots (Amazona leucocephala L.) and noticed the large holes in the upper portion of royal palm trunks excavated by them for nesting sites.

Another hour through sparsely timbered low hills brought us to the San Marcos River, its banks fringed with vivid green bamboos. The water was very high and the current strong, but 
Pablo plunged in and we followed in single file. Pablo knew just how to fold up his legs in front and escape further wetting, but, after all, there is no superlative to wet.

Arrived at the tienda we were surprised to find Lesmes awaiting us with a pilot. It appeared he had been worrying about our finding the way through the reef, when we should finally start for the schooner at Bahia Honda. Yielding to the impulse of rescuing us from a possible danger he secured a local pilot and in a tiny little craft had put back to Mulata to accompany us "home." We appreciated the kindly feelings that had prompted his actions.

In the evening Pablo extended us an invitation to visit his mother and sister at their finca near by. There our suspicions about Pablo were verified. He was not the ordinary campesino that we had been justified in expecting but, on the contrary, a man of education and world experience. His acting as a guide and mozo for us had been but a lark which he had thoroughly enjoyed. We glanced at each other apprehensively at thought of Pablo having possibly understood more of our English than he had admitted. We had 
denounced him roundly for the length of the journey, which, of course was unfair. We found his family most agreeable.

Before turning in for the night we secured some specimens of a huge ground toad that appeared to be quite abundant about the tienda (Bufo peltacephalus). It is one of the largest of all toads, measuring six and a half inches in length and four in breadth; it is confined to Cuba. Its affinities are South American and it has no close relationship with any of our United States species. As one always associates with animals observed a certain size as proper and fitting, to discover one of quite double dimensions is startling. 

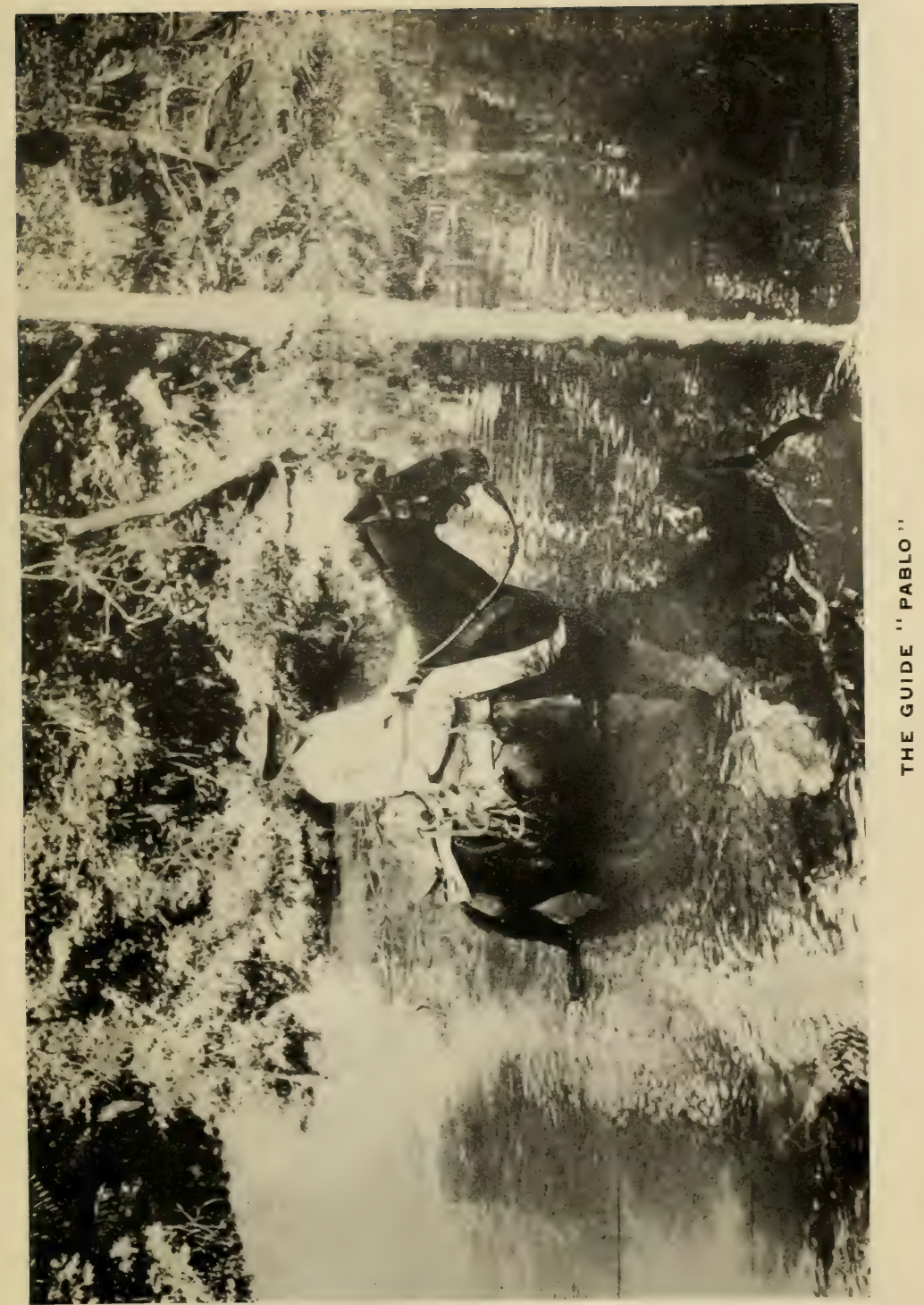



\section{CHAPTER XXIII}

\section{La Mulata to Bahia Honda}

Saturday, June 6th. By six our party in the little Tarpon was well on its way to Bahia Honda. With regrets we gazed back at Guajaibon and the receding ranges to the west, for we had become greatly attached to the sierra country, to its precipitous forested heights and rich valleys. We liked its simple unspoiled people who still retain the courtesies of a past era. We knew the topography and the salient geological features of the region, and believed we understood them. There in splendid revelry nature predominates and man, in his little scattered villages and tiny farms, is of the smallest incident. Now we were about to enter an entirely different country where the wilds are subdued, and man is paramount with his cities, his commerce, his highly cultivated estates, and his restless politics.

We proceeded rapidly steering closely into the shore to avoid the coral patches that became more 287 
and more frequent. Ugly-looking clouds filled the sky, and puffy winds suggested a chubasco. Passing Punta Pereira and the mouth of the Manimani River, a haunt of crocodiles, we entered waters thickly strewn with dark coral patches. The main reef now approached very near the shore. As we made Punta Gobernadora, the way ahead seemed to be entirely blocked by a continuous line of coral which, beginning at the very beach, extended in a wide semicircle to the north and west. Upon this outer barrier the surf broke with considerable violence creating areas of creamy white foam. A strong eastern drift opposing the wind aided us in our course but ruffled the surface into a steep chop resembling a tidal rip. The waves prevented a clear view of the bottom but it seemed uncomfortably close to our keel. Suddenly the pilot altered the course heading directly for the nearby reef. The situation became tense as all strained their eyes to locate the passage through, and no one spoke. When apparently in the midst of the breakers a deluge of warm spray swept the boat; our engine, short circuited, stopped. Fortunately the halt was brief; the engine responded promptly to our coaxing, and we 


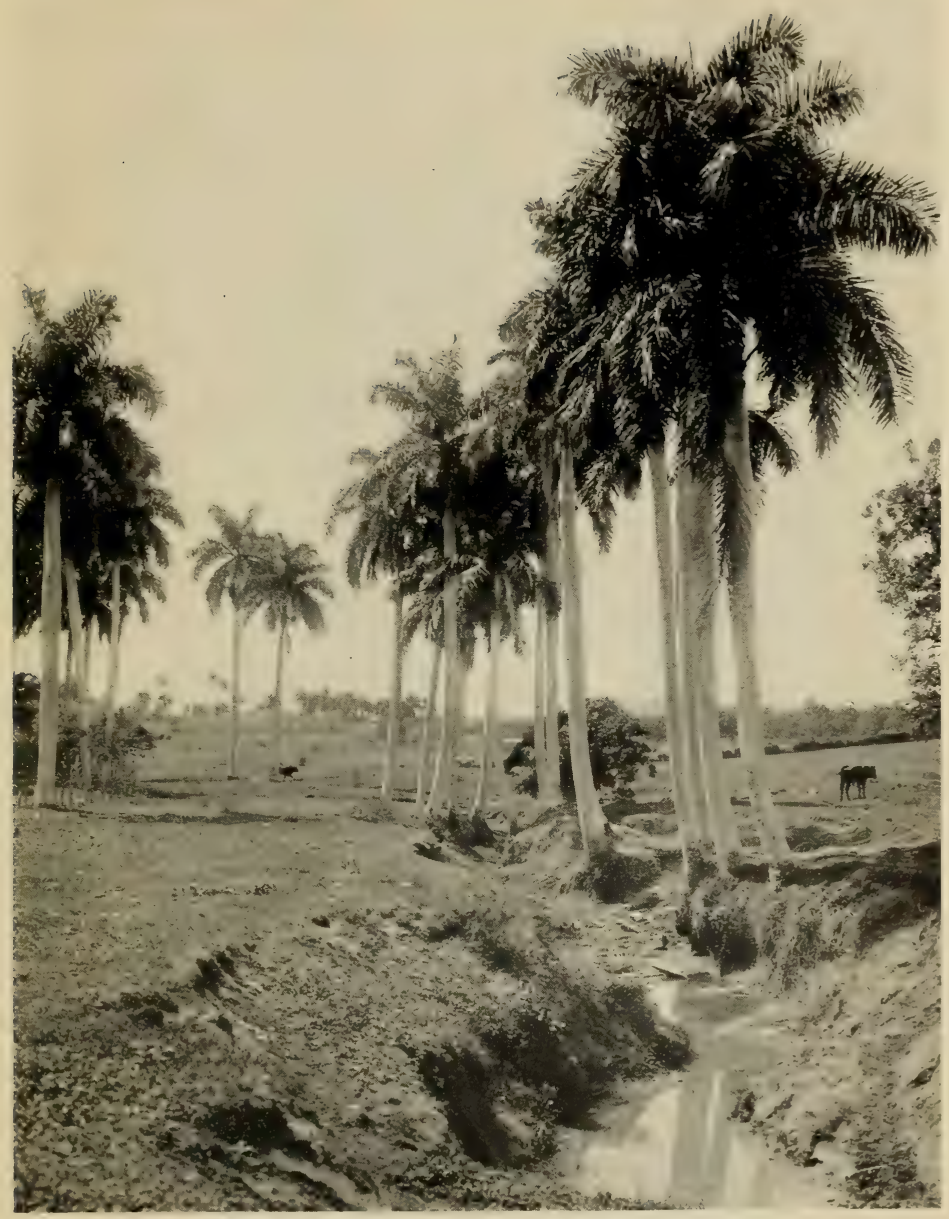

ROYAL PALMS

Reproduced by permission of the American Photo Co., Havana, Cuba 

shot through the welter of white and green into the blue of safety. The long even swell of the open sea made easier going and soon we entered the harbor of Bahia Honda and made the schooner's side. Lesmes was right; the pilot had been necessary. Without him we would have been obliged to await better weather conditions before attempting that reef passage.

Bahia Honda is a typical example of the "flask" or "bottle"-shaped harbors so characteristic of the Cuban shore. Many of these peculiar harbors are met in the eastern end of the island where a series of elevated reefs often provide a strip of highland adjacent to the shore with a lower drainage area behind. The narrow deep harbor entrance (the neck of the bottle) represents a cañon eroded down by a river during the course of a gradual elevation of the shore; the open wide expanse of the harbor (the body of the flask) represents a wider inner valley or a drainage sink, the present condition finally resulting from a subsidence of the coast and drowning of the valley. No better demonstration of the process involved could be imagined than that presented by the Yumuri Valley and the cut through the limestone 
hills made by the river just before it debouches into the sea at Matanzas. A subsidence of a hundred feet would convert the Yumuri Valley into a very large "bottle harbor."

From Gobernadora Point east (to about Cardenas) the island shelf is exceedingly narrow, and the blue water of the ocean depths is seen close into shore. In a few places coral reefs flourish upon this very narrow shelf, especially about the harbor entrances, but there is no opportunity for such extensive growths as we had seen to the west where a wide island shelf furnishes many hundred square miles of suitable depths for the coral polyps.

At Bahia Honda it was at once apparent that we were in quite a new type of country. A range of high hills some ten or twelve miles inland appeared from a distance to be a part of, and continuous with, the Organos system. This, however, is not really the case. Guajaibon is the eastern outpost of the northern series of the Organos Mountains, and the high hills continuing east are structurally different. The southern ranges of the Organos uplift do, however, extend farther east than the meridian of Guajaibon and carry the sierra fauna and flora to about the line of the 
Havana province where they rather abruptly cease. About Bahia Honda and to the east thereof there is a capping of bluish white limestone, probably Tertiary, though more eroded and less in evidence here than in the central eastern part of the same province. The pine lomas, which constitute so important a feature of the Pinar province are here entirely lacking, but the underlying serpentines are more frequently exposed.

Our launch party was received aboard with enthusiastic acclaim. Those remaining with the schooner had spent two wretched nights fighting mosquitoes. Just why this port should be so infested while other wholly similar localities should be exempt, is not clear. In the daytime, the pests are quiescent but at night they are indescribably bad. Fortunately they are less poisonous than the smaller inland species we had encountered at Cape San Antonio.

As some shopping was necessary, most of us, including the Patron, landed at the embarcadero and walked the mile and a half to the town of Bahia Honda. There we obtained a supply of mosquito netting, fresh vegetables, and a wheelbarrow full of delicious mangoes. The town pre- 
sents every appearance of better days and the residents look unhealthy. Ill fortune broods over the place. Trade is low and the death-rate high.

Returning to the landing place, we took a few land-shells in a prosperous looking cemetery. These were of the Havana province type with some common species of very general lowland distribution, but none even suggested the sierra fauna.

Our hopes for good marine collecting in and about the entrance of the harbor had been running too high, for we found in the soft muddy bottom little of life to interest us and any reef collecting outside was made impossible by the rough sea. In Professor Nutting's charming account of the Iowa State University expedition to the Bahamas and Cuba (I895) he relates the misfortunes of the party in this port. We, too, met here our one and only instance of official interference, although we were in no way inconvenienced by it. It amounted merely to a display of a rather fussy authority on the part of the port officer, who seemed much exercised over our lack of clearance papers. Our explanations never fully satisfied him that we were neither pirates nor revolutionary agents. 
For the first time we received here the Patron's positive prohibition against jumping overboard. We were anchored in some forty feet, and the murky water of the bay prevented sight of the bottom. We made up for the restriction by landing on a sandy spit near by where we hunted Cerion and swam to our heart's content, Luis and Mulatica joining us in the sport. Lesmes and the pilot, who seemed determined to attach himself to the Barrera, went fishing in deep water, returning about dark with an interesting catch, claimed to have been made in a thousand-feet depth. We doubted not the word of Lesmes but the correctness of his soundings. 


\section{CHAPTER XXIV}

\section{Bahia Honda to Cabañas}

Sunday, June 7th. Some of the Barrera's party did not awake this morning, for the simple reason that they had not slept. Despite our new nets, most carefully adjusted, we suffered a veritable massacre by the mosquitoes. In the fact that only female mosquitoes bite we may derive a halfhearted consolation. A query naturally arises anent these blood-thirsty insects; How can such countless swarms of them find enough food? Surely, if all mosquitoes had just one square meal, not a drop of red blood would be left-the Mammalia would suddenly become extinct. Obviously blood cannot be their sole diet.

Since the discovery that mosquitoes are the source, indeed the only source, of malarial and yellow-fever infection, a considerable amount of close research work has been devoted to a few species, particularly of the genera Stegomya and Anopheles, which are known to be the disease- 
carrying insects. There are, however, a vast number of species of mosquitoes of unknown habit, except possibly by inference. Generalizations therefore may be dangerous, but from all observations so far made it would appear that the bloodsucking habit is an acquired one, the natural food being, or having been in the past, the juices of plants and fruits. Any liquid containing organic matter is acceptable. The exudation from animal wounds, with its slightly sweetish serum, probably offered to these ravenous insects their first step toward blood-sucking. The highly organized apparatus, especially of the female, for puncturing leaves, needed but slight modification for becoming a most perfect surgical instrument for tapping the skin of animals for their blood. It seems also to be true that the habit of blood-sucking is confined almost wholly to the females, for they have now become dependent upon a supply of blood for the nutriment, not so much of themselves, as of the eggs developing within their bodies. Without such supply their eggs will not mature to the point necessary for oviposit. This very special habit of the females has naturally developed their organs for getting blood to a degree far beyond those 
possessed by the less dependent males. The various species of mosquitoes already studied have been known to feed upon the blood of mammals, birds, snakes, and of other insects, and even upon the dead. With such habit one may easily understand the risk of any mosquito-bite. In the particular case of the fever-breeding species it is now known that the malarial protozoan can only complete its life cycle by a residence for a period within the body of the mosquito, and the same is true of the yellow-fever germ. When the protozoans are ready for transmission to the next host, they occupy the salivary glands of the mosquito there awaiting their transference into the blood of a mammal where they complete their cycle in the hæmoglobin of the blood-corpuscles.

Bartsch and Greenlaw, dissatisfied with dredging results in the harbor, proceeded in the launch to the narrow entrance and made a number of dredge casts in three to fifteen fathoms, getting but meager returns for their labor. Clapp and I undertook the cleaning, preserving, and stowage of the Guajaibon material, a task occupying the entire morning. Another party went for Cerion and finally all joined for a swim at the sandspit. 
Alas for the little tree ducks. Our tenderest care could not save them. Their ambitions to climb the companionway stairs and range the deck proved to be their undoing. We dropped their limp fluffy little bodies overboard and watched them drift away with the tide.

As further stay at Bahia Honda seemed useless, we decided to proceed at once to Cabañas. Bartsch, Clapp, Rodriguez, and I landed again, and at the town caught the motor-bus that makes a daily run to Cabañas, arriving at our destination about 5 o'clock. The country traversed en route takes on more and more the aspects of the Havana region. Low hills of an impure limestone capping a loose disintegrated serpentine are a feature. The decomposition of this rock provides a soil of high fertility as evidenced by many royal palms, ceibas, poinciana, and the dense foliaged Ficus religiosa-the latter grown for ornamental purposes. Sugar estates appear along the road, and the indication of prosperous farming is everywhere sensed. The same range of rather high wooded hills that we recalled as beginning near Guajaibon and continuing unbrokenly to the east still forms the dominant feature of the landscape. 
Just back of Cabañas at a distance of some six or eight miles, the range apparently culminates in a wooded height of about one thousand feet. We could distinguish no paredones or rock walls, but to satisfy our curiosity about these hills we determined upon their exploration the following day and accordingly made arrangements at the hotel for a guide and horses.

The town of Cabañas is too near the larger Havana ever to expand into a real city, but it possesses far more life and brightness than its moribund neighbor we had just left to the west. The open hotel cafe or dining-room appears to be the rendezvous of the local "sports" who gather about its little round tables to sip coffee, throw dice, and settle all sporting matters. These momentous questions sometimes kindled an astonishing degree of heat with much emphatic banging of the tables.

The Barrera left soon after our departure and arrived the same night in the harbor of Cabañas. 


\section{CHAPTER XXV}

\section{Cabañas}

Monday, June 8th. One of the hills in the range south of Cabañas is "Rubi," the unique locality of a rare Urocoptid which Dr. Torre especially wished us to obtain. There is also hereabouts a very desirable but local variety of the widely distributed arboreal snail, Liguus fasciatus, a small form of vivid yellow coloration. At 6 A.M., Bartsch and I mounted the large ungainly horses awaiting us, and fell in behind our cross-eyed guide. The route took us a mile over the carretera that we had traveled the day before in the diligencia, and then south along an ox-cart road which finally attenuated into a bridle path. This led us for a time through a gently rolling country of cane fields, and then ascended into a belt of higher wooded hills of smooth contour and showing no rock exposure. In about two hours we reached the summit of the first line of foothills flanking the high range, not over a mile beyond. As we began 
our descent into the forested valley between, we were obliged to pass through a clearing, in the center of which stood a rude shack. From this emerged two men who signalled us somewhat brusquely to stop and then positively forbade us to proceed. No amount of explanation of our innocent intentions could prevail upon these obstinate men, nor would they offer any reason for their interference. Probably they suspected in us prospectors for mineral. There being no other route to the mountains save by an arduous detour of many miles, we were obliged to content ourselves with this fairly near view of the range. It is quite certain, however, that there is no rock exposure besides one small outcropping visible near the highest point of elevation. This is likely a bit of limestone-capping, although the Cerberus of the mountains assured us it was a friable sandstone. Enough was seen, however, to convince us that these hills had no connection geologically with the Jurassic series of the western province. No sign of any land-shells could be found along the lower hills and we started homeward sadly disappointed. In a bank of reddish clay, a mile or so from the town, we discovered a few crumbling 
fossil marine shells (apparently of existing species) mixed with some land-shells (also of modern forms) but rather larger than their living descendants. These Pleistocene fossils evidently were not in original situ, their matrix having been eroded away. Upon completing our futile eighteen-mile ride, the guide indicated as "Rubi" a treeless hill in quite another direction and then our disgust was complete.

In the meantime Clapp and Rodriguez had been scouring the country between the city and the bay. Their fortunes had also been poor except for one dead specimen of the coveted yellow Liguus and some minute land-shells of no especial interest. The ground was exceedingly dry, no rain having fallen for many days. This seems not a little strange considering the full swing of the rainy season but a few days' journey to the west.

Rejoining the schooner about one o'clock we immediately set out in the launch for the line of reefs that fringe the eastern side of the narrow harbor entrance. Cabañas Bay is a typical "flaskshaped" harbor with an exceedingly narrow and deep entrance cut through an elevation of modern 
limestone. The inner harbor covers two drowned valleys leaving exposed a ridge between them, now represented in part by an island upon which is an old fortress (Reina Amalia) a survival of the era of round cannon-balls. On the western side of the harbor entrance is a rather steep elevation of about two hundred feet-the remnant of a once much higher coastal ridge. It is densely covered by scrub growth and surmounted by a lighthouse.

Being favored by a very low tide we were enabled to examine carefully the entrance shore line, to explore many tide pools and the inner portions of the reef. Our fine catch compensated us for our morning's failures. This proved to be one of our very best littoral stations for marine invertebrates. A few dredge casts were made in the channel with fair success. An attempt to explore the woods was frustrated by the incredible number of mosquitoes. A small Chondropoma of the coastal belt type was discovered, although all our specimens were occupied by hermits. Clapp and the Patron, however, succeeded in getting many Cerion mumia.

A still moonlight night of rare charm followed the close of day, but our pleasure was sadly marred 


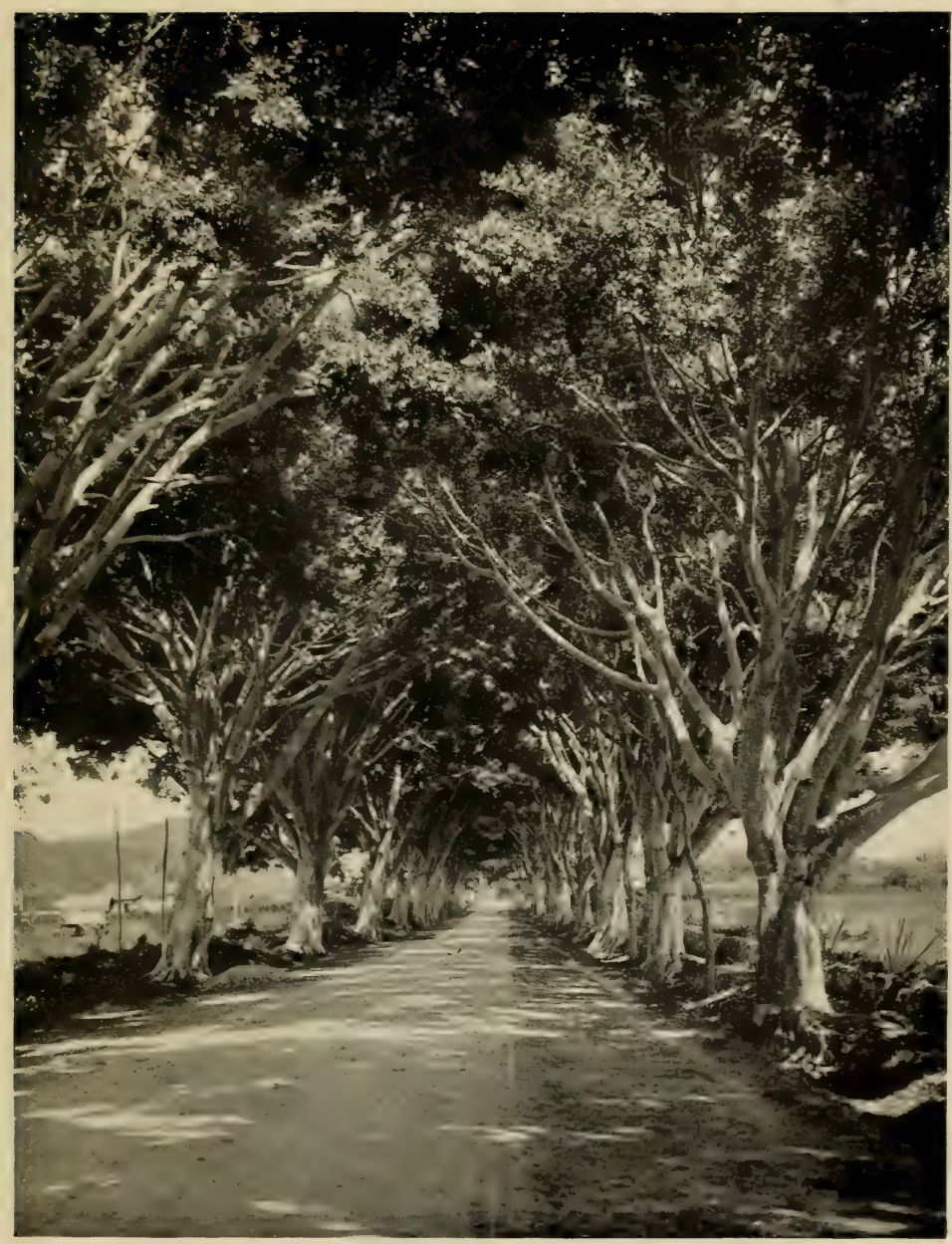

FICUS TREES ALONG A COUNTRY ROADWAY

Reproduced by permission of the American Photo Co., Havana, Cuba 

by mosquitoes that drove even Luis and Mulatica to cover. Without the nets purchased at Bahia Honda we should have fared ill indeed.

Tuesday, June gth. In solemn conclave we had reluctantly decided that this must be our last day of collecting. Already we had exceeded the time of our charter, and most of us, our periods of leave from home. By a division of labor and with forced energies we proposed to "do" Cabañas harbor and vicinity before nightfall. Clapp, Rodriguez, Lesmes, and Pablo mobilized for a raid upon a peninsula in the harbor known as the old "Potrero Constante," their chief object, landshells, with the pretty yellow Liguus in view as a special prize. Bartsch, Greenlaw, and an assistant set forth to dredge in the harbor entrance. They made two fairly successful hauls in twenty-five fathoms and seven in eight fathoms, taking a quantity of small bivalves as the feature of their catch. When the shore party returned, a generally battered appearance fully confirmed their story of mosquitoes and thorny scrub. They had secured but a half-dozen dead specimens of the coveted Liguus.

The next excursion, including all the collectors, 
proceeded first to the island fort, "La Forteleza de la Reina Amalia," where a quantity of Cerion (C. mumia hondensis) was gathered. These white pupæform shells clung to the bushes in astonishing abundance, as though a part of the vegetation itself. Besides these, we were fortunate in securing a good representative series of the coastal strip land-shells including Urocoptis, Subulina, Pupoides, and Thysanophora. The rocks of the island littoral, deeply concaved at the water's edge by wave action, offered a tempting field for marine work and a portion of our party remained to explore them. The Patron and I crossed to the western entrance of the harbor to examine the lighthouse hill, while Bartsch and Greenlaw continued in the launch to the outer eastern shore of the harbor entrance to copper-sulphate the tide pools.

We found ourselves within a scrub forest growing apparently out of the solid reef limestone. Traversing this, we emerged into an open cane field, beyond which rises the hill. The upward path is cut through a very dense jungle of small trees to a clearing on top. In these woods one hears the continual rustle of myriads of hermit 
crabs, many of them occupying the broken or badly weathered shells of our particularly desirable yellow Liguus. Undoubtedly this hill must be the central factory of this very locally distributed variety, but at this dry season no living specimens could be found beyond two or three juvenile ones. Insect life was exceedingly abundant, and we exhausted ourselves in the chase of some exquisite butterflies that defied capture. Unfortunately, Rodriguez, with his net and cyanide jar, was elsewhere.

On the summit of the hill is perched the lightkeeper's house and by its side a skeleton frame structure supporting the lamp. Close by, and almost buried in creeping vines, is the ruin of a large stone house. From its crumbling piles of masonry grow some very large and fine old trees, their roots entwining the broken casements and arches of the structure, and their dense foliage casting upon the ancient foundation a grateful shade. As we approached the keeper's house, a dog, resembling in size, color, and ferocity, a Bengal tiger, rushed out upon us, and the Patron and I drew together in full realization that our end had come. Escape from such a monster was 
obviously impossible and to have to die just then and there seemed indeed a pity, but we resolved to die together and bravely. In the very nick of time, a woman appeared from the house and called off the mammoth creature.

We were most hospitably received by the aged couple who jointly and without assistance attend the light. Their abode, well appointed with many evidences of refined taste, and a model of neatness, at first disconcerted us, so accustomed had we been to the bohios of the peasants. With easy courtesy, reminiscent of Castilian days, this kindly couple insisted upon our lingering over their excellent coffee and cakes, a temptation indeed notwithstanding our eagerness to make the most of our last day in the field. And so we tarried under the charm of their personality, marveling at this gentle Spanish couple, who, amid simple duties and isolated upon this hilltop, had captured the elusive sprite of happiness and induced her to abide with them.

While chatting, a young man in somewhat formal dress appeared. He was also a Spaniard of the ancient régime-a student of philosophic and poetic turn of mind, who found in the lightkeeper 
and his wife a congenial companionship. He had with him some old books, just received from Spain, containing marked passages of especial beauty, which he wished to share with his friends. His graceful sentences were expressed in lisping Castilian and adorned with many subjunctives.

Upon leaving, the hostess pressed upon us some flowers from her garden, the stems of which she carefully wrapped to protect our fingers from possible thorns, and the host presented us with a slip of paper upon which he had written "Antonio Leit-In grateful recognition of a delightful visit." As though our welcome had not yet been wholly complete, the huge dog added his own by leaping upon us to lick our faces.

Among the ruins of the old stone slave house, for such had been its use in slave-importing days, we made a fine catch of insects, land-shells, and lizards. For the latter, the spot seemed a veritable metropolis. Among several lizards caught was one not often seen-the Cuban chameleon (Chamcooleolis chamceleontides). Although not a true chameleon, which is an old-world lacertilian, it passes by that name in Cuba, and the authors of its scientific name have seemingly approved. It 
is in reality an anolid but is the unique species of a genus confined to Cuba. The specimen was light green when taken but turned much darker a few minutes after capture. He surprised us by his bad temper and had to be handled with much caution. We only saw three of these tree lizards in Cuba-one in Viñales and the last at Cabañas. Of smaller species of $A$ nolis there are always many about, running and leaping with the greatest agility. The Cuban species are generally peculiar to the island. In the cane fields below we discovered some Hemitrochus that were quite new to us. While awaiting the return of the launch we took many more excellent things along the exposed flats, adding to our trophies several large species of mollusks and holothurians.

The launch party that had been "doping" the pools of the reef reaped a harvest of marine creatures. Bartsch reported the richest returns yet obtained on the entire trip. Before leaving the harbor entrance, our entire party had the good fortune to assist some fishermen in hauling their purse seine. Their big net slowly drew in, while the Majorcan fishermen chanted a song to mark the time for united efforts in pulling the ropes. 
As the pocket approached, a great commotion and flashing of silvery sides gave assurance of a successful haul. A heavy catch resulted, principally of "biajaiba." Among the many species of edible fish brought to the Havana markets the biajaiba (Neomanis synagris) is probably the first in importance, both in quantity used and in popular estimation. A large specimen weighs about four pounds, and the flesh is well flavored. They are taken in great quantities about the mouth of harbors. This is really a beautiful fish of a bright rose color with silvery tinge below. It is the "Lane snapper" of the Florida Keys and not the better-known red snapper so extensively shipped from the Gulf to northern markets. The next in importance among Cuban food fish is the exceedingly pretty little "yellow-tail" of the Florida Reefs-called here "rabirubia" (Ocyurus chrysurus). One can never do better when ordering at a Cuban restaurant than to call for rabirubia. The size rarely exceeds two or three pounds. In attempting to describe this or any other fish of tropical waters one cannot avoid the superlatives of beautiful, or bizarre. This one is simply beautiful, the predominating colors, being a vivid yellow and blue. Although 
caught about the reefs it is not a reef fish in the sense applied to the many brilliant fish mentioned as living about the corals. The yellow-tail is free swimming. In Havana one constantly sees upon the bill of fare the word "pargo" offered in many varieties of preparation by the clever Cuban cooks. This excellent fish (Neomanis analis) is taken in all the harbors along the coast and ranks about third in commercial importance. It is the "mutton-fish of Florida." The little "cabrillo" with enormous head and spindling body is less often served but is a most delicious fish when prepared in true Cuban style. It ranks about fourth in importance. The various groupers are also used as food, especially the Epinephelus morio, or red grouper, but they are less esteemed. These large reef fishes sometimes take on a poisonous quality, but the fishermen insist upon their ability to distinguish between the good and bad and there are very few "accidents." Strangely enough the Cubans will not touch flounders. There are several species in the shallow waters of the coast and all probably excellent, but owing to some prejudice the fish so highly prized in all other countries is altogether taboo. We selected from the nets examples of 
several species for our collection, notably one of bizarre form called by the fishermen the jorobao. This truly remarkable-looking fish (Selene vomer), which is both beautiful and strange, is of a uniform polished silver and of very peculiar form. Its much elevated compressed body, short head, with nearly vertical profile, and the two or three very elongated filamentous dorsal spines, combined with the flashing brilliance of its silvery sides, make a combination that one can never forget. It is also eaten as a pan fish but does not figure as an important article of diet. It is also found on the Pacific side of the isthmus.

All of the fishes referred to are of general distribution throughout the Antillean region including Southern Florida.

It was well after dark when we returned to the schooner and past midnight before the day's abundant catch could be properly disposed of.

No more beautiful night could be imagined than this, our last one aboard. The doubtful weather conditions of the past several days had given place to that perfection of air and sky which makes all the world seem fair. An almost full moon reflected its light upon the placid waters. 
Ashore, the burning of cane-refuse illumined the fields bringing us the crackle of blazing fires and the aromatic odor of its smoke. Most wonderful of all, there was entire freedom from mosquitoes.

So beautiful a night could but accentuate a gloom oppressing us all, although its perfection appropriately marked the end of our voyage. No friction had marred our close association of many days. Working strenuously toward the common end, a spirit of helpfulness imbued one and all, including our Majorcan crew. Indeed a happy mood of levity and badinage had always reigned, and discomforts had been laughed away. We had been a very happy family in our little floating home. We were now to separate, probably never to reassemble under such similar pleasant auspices.

The following day we left the schooner and proceeded to Havana (by diligence to Guanajay and thence by rail). The schooner arrived the next morning and we at once began the arduous task of packing our material for shipment to Washington-a task that required two full days of hard work. Of the thousand or more jars of alcoholics but one was broken when the crates and barrels were unpacked at the National $\mathrm{Mu}$ - 
seum. The immense amount of material was soon separated into its phyla and consigned to the various specialists who will in due time report upon it.

Leaving Havana by the Key West steamer, Bartsch and I, the last of our party to leave Cuba, waved adios to the Tomas Barrera lying under the shadow of Cabañas fortress, the last episode in a delightful outing and most successful collecting expedition. 



\section{INDEX}

A

Acrocomia lasiospatha, 16

Acropora palmata, 78

Adiantum, 32

Echmeas, I93

EDolids, 122

Agave plants, 89

Alacranes Keys, 256, 257

Alsophis angulifer, 198

Amazona leucocephala, 284

American deer, 269

American Egret, IoI

Ammotrypane, I85

Ampullaria, I77

Anarcardium occidentale, 72

Anhinga bird, IOI

Ani bird, 230

Annularia pretrei, 28I

Annulata (phylum), I24

Anolis, 308

Anopheles, 294

Anthurium, 32

Antillean snakes, 238

Arango, Rafael, 38, 43

Arriero bird, 94

Arroyos, Los, I 37

Audubon's Caracara, 21 8

Avalo (Cape), I43

Azucar, Pan de, 80

B

Bahia Honda (Bay), 289

Bahia Honda (Town), 29I, 292

Bamboos, 260, 284

Barracuda (fish), 48, 5I

Bauhinia heterophyla, 85
Biajaiba(fish), 309

Blasospira echinus, 227

Blind snake, 25

Bob-White (Cuban), 2 I 8

Bottle-palms, I 7

Bottle-shaped harbors, 289

Bougainvillea, 18

Brassavolas, I 93

Brassia, I93

Bromeliads, I93

Bufo peltacephalus, 286

Bulla, IоI

\section{C}

Cabañas (Bay), 30I

Cabañas (Light), 305

Cabañas (Town), 298

Cabrillo (fish), 3 IO

Cacti, 89

Canobita clypeatus, I76

Calliostoma sp., I 85

Calyptronoma swartzi, 72

Cape Avalo, I43

Cape Cajon, I5I

Cape San Antonio, I5I, I86, I87, I9I

Capromys, 197, 198

Capromys melanurus, 197

Capromys pilorides, I97

Capromys prehensilis, 197

Cardisoma guanhumi, I79

Cashew nut, 72

Cativo snake, 247

Catopsis, 193

Cave formation, 32

Cayo Arenas, 47, 5I

Cayo Hutia, 55

Cayos de la Leña, I 5 I, I 54, I 56

3 I5 
Cecropia peltata, 90

Ceiba (tree), 72, 209

Celtis aculeata, 77, 85

Centrochinus setosum, 57, I59

Centurus superciliarus, 195

Cepolis jaudenesi, I82

Cepolis sagraiana, 28I

Cepolis subtussulcata, $3 \mathrm{I}$

Cepolis supertexta, I 7 I, I 83, I95

Cerchneis sparveria dominicensis, 218

Cereus pitajaya, 89

Cerion, 44, 5I, I56, 293, 296

Cerion n. Sp., I7 I

Cerion mumia, 302

Cerion m. hondensis, 304

Cerro de Cabras, 235

Champelia passerina aflavida, 218

Chamaoleolis chamaleontides, 307

Charcoal, 190

Chinese Hibiscus, 18

Chiococca, 85

Chiton, 199

Chondropoma, 302

Chondropoma latilabre, $28 \mathrm{I}$

Chondropoma sinuata, 275

Chondropoma vinalensis, 248

Chrysophyllum olivaforme, I7 I

Chubascos, 65, I41, I74, I89, 209

Clusia, 87

Clusia rosea, 87

Coccolobis uvifera, 170

Colorados Reefs, 56-64

Colpothrinax wrightii, I7

Columba leucocephala, I69

Conus, 199

Copernicia, 72

Copper deposits, I05, 107

Copper sulphating, 204

Corrientes (Cape), 188

Corvus minor, II 6

Costanera, 81

Costanera del Abra, 43
Costanera de San Vicente, 39, 43

Cove of Delight, 32, 245

Cow-fish, 120

Cow-itch, 88

Crew, 12

Crotophaga ani, 230

Cuban Bast (tree), I75, 190

Chameleon, 307

food-fish, 309

Grackle, I95

Green Heron, I0I

Green Woodpecker, I95, 284

Ground Dove, 218

hospitality, 39

mammals, 196

modesty, 42

music, 28

Oriole, 284

Parrots, 284

Slug, 274

Sparrow-Hawk, 218

sub-faunal regions, 34

Trogon, I95

Cyathea, 72

Cyrtopodium, 193

\section{D}

Davallia, 32

Deer, 269

Dendrocygnea arborea, 201

Diadema (sea-urchin), 57, 59, I 59, 160

Dimas, II6

Dos Hermanos (mogote), 231, 235

Drillia, 166

E

Eleutherodactylus auriculatus, 271

El Punto, 77, 81

Emoda, 9I 
Ensenada de Cajon, 152

Epicrates angulifer, 238

Epinephelus morio, 310

Equipment, 7, 8

Erythrina, 86

Eugenia vulgaris, 280

Eurocoptis blainiana, 275

Euterpe manaele, 89

Eutrochatella regina, 76, 9I

\section{F}

Fan Leaf palm, I7I

Farallones, 216

Faulting of strata, 105, 106

Fer de Lance snake, 238

Ficus crassinervia, 76

Ficus religiosa, I 8, 297

Flask-shaped harbors, 289, 301

Flounders, 3 Io

Fossil shells, $2 \mathrm{I} 7,30 \mathrm{I}$

Fringing reefs, 207

\section{G}

Gaussia princeps, 89

Geology of Pinar del Rio, I08, I I I

Gliricidia platycarpa, 86

Goniopsis cruentata, 164

Gorgonia acerosa, I57

Gorgonia heptogorgia, I 57

Gorgonia virgulata, I 57

Groupers, 58, 310

Grus nesiotes, 218

Guadiana Basin, 21 5-2I7

Guadiana (Bay), I 43

Guajaibon, Pan de, 269, 270

Gundlach, Juan, 36

Gumbo-limbo tree, I 92

$\mathrm{H}$

Haloquiscalus gundlachi, I 95 Helicina, 182
Helicinids, 9I

Hemiramphus braziliensis, 202

Hemitrochus, 308

Hermit crabs, I 76

Herradura, I5

Hibiscus rosa-sinensis, 18

Hippocampus, 145

Honeycombed limestone, 16I, I62

Hospitality, 70

Hubo snake, 198

Hutia lighthouse, $5^{2}$

Hutias, 196

Hydroid colonies, 157,158

Hyla, $27 \mathrm{I}$

Hymenophyllum, 32

\section{I}

Icterus hypomelas, 284

Inodes palmata, 16

Inodes umbraculifera, 16

Ipomcea pes-capra, I70

Iron ore, I05

Island shelf or platform, 127I 30,290

Iulus, 92, 273

\section{$\mathrm{J}$}

Jejenes, $\mathbf{5 5}$

Jorobao, 3 I I

\section{K}

"Kilometer 14," 14, 20, 24, 22I, 235

\section{L}

La Chorrera, 38

Lactophrys tricornis, 120

La Esperanza, $4^{\circ}$

Lavicardium, IoI

$\mathrm{La} \mathrm{Fe}, 143,215$

La Mulata, $25^{8}$ 
Land crabs, I79

Land shells, 33

Lane Snapper, 309

Leaf-cutting ants, I8I

"Life-Wheel," 53

Levisa Keys, 25I, 255

Liguus, I77, 195

Liguus fasciatus, 299, 301, 303, 305

Lima, 206

Limax maximus, 274

La Penitencia, 235

List of party, 12

Little Blue Heron, I0I

Littorina angulifera, I65

Littorina lineata, 165

Littorina zigzag, I65

Live-Oaks, 7 I

Livona, 177, 199

Lizard Cuckoo, 94

Loggerhead sponge, 159

Loma, 20

Los Arroyos, I37

Louisiana Heron, ror

Luminous beetles, $9^{8}$

\section{M}

Mcandra areolata, 57

Mahogany, 192

Maidenhair ferns, 32

Maja snake, 236

Malas Aguas River, 77

Malpighia, 73

Malpighia urens, 88

Mangoes, 29I

Manimani River, 288

Marine gardens, 157

Matahambre mine, 73, 74, 105

Melanians, 260

Mendoza, 219

Metamorphosis in coral rock, 164

Metopium, 75

Mexican cormorant, IOI

Mimosa pudica, 228
Mimus polyglottus orpheus, 2 I 8

Mitra, 199

Mocking bird, 218

Mogotes, 20

Mogote de Pan de Azucar, 43, $8 \mathrm{I}, 82$

Mogote de la Gran Vega, 226

Mogote de la Mina, 43

Mogote de la Sagua, 43

Morelet, Arthur, 277

Morse, C. K., 74, 75

Mosquitoes, 29I, 294, 295, 296, 302

Mucuna pruriens, 88

Mucuna urens, 86

Mutton fish, 3 Io

Myomorthus, 282

Myriopods, 92

\section{$\mathrm{N}$}

Neomenis analis, 3 I0

Neomanis synagris, 309

Nerita, 166

Nudibranchs, I22

Nutting, Professor, 292

$\mathrm{O}$

Ocyurus chrysurus, 309

Odocoileus virginianus, 269

Oleacina straminea, 9I

Oncidium, 193

Oolitic mud, I30

Organ Mountains, 2I, 290

$\mathrm{P}$

Pagurids, 176

"Pancho," 262

Pan de Azucar, 80

Pan de Guajaibon, 269, 270

Panulirus argus, 57

Pargo, 310

Pecten, $1 \mathrm{I} 8$

Peña Blanca, 80 
Personnel of expedition, 4,5 , 6,12

Piad, Señora, 38, 246

Picoua, 48, 5I

Pinar del Rio, 22 I

Pinatillo (Cape), I43

Pinus caribca, 72

Pinus occidentalis, 2 I 7

Pisania, 199

Pisonia aculeata, 84

Pitcairnias, 193

Pithecoctenium aubletii, 85

Plankton, 52

Pleistocene, I42

Pleurodonte guanensis, 9I

Plexaura, 157

Poey, Filipe, 37

Poinciana, 280

Poiretia sp. (tree), I9o

Poisonous snakes, 238

Polyborus cheriway, 218

Polymita picta, 275

"Potrero Constante," 303

Priotelus temnurus, 195

Puerta del Ancon, 3I, 32, 245

Pull and Haul vine, 84

Punta Colorado, I4I

Punta Gobernadora, 288

Punta Lavanderas, 25I

Punta Pereira, 288

Pupoides, 304

Pylopagurus discoidalis, 178

Pyramidella dolabrata, 185

Pyrophorus noctilucus, 98

$\mathrm{R}$

Rabirubia, 309

Reddish Egret, I0I

Red Grouper, 3 I0

Reefs, II3-II5

Reef fish, 58

Reina Amalia Fort, 302, 304

Rhipidogorgia flabellum, 157

Rhipsalis, 90
"Roncali" (Lighthouse), I5I, I 87

Rose-apple, 280

Royal Palms, I5, 260

Roystonea regia, I5

Rubi (Hill), 30I

\section{S}

Sacred "Bo" tree, I8

Sacred "Ti" tree, 18

Sand flats, I28, I3I

Sand flies, 55

Sand Hill Crane (Cuban), 218

Sand islands, I28, I3 I

San Andres range, 43

San Juan de Sagua, 265

Santa Lucia, 70

San Marcos River, 259, 263, $265,280,284$

San Vicente de los Baños, 38

Satin leaf tree, I7 I

Saurothera merlini, 94

Sea-grapes, I 70

Seasickness, I I 3

Seborucos, I9I

Selene vomer, 3 I I

Sense organs, II 9

Sensitive plant, 228

Sharks, $48-50,62$

Sheepswool sponge, I 58

Shore strip, I27

Sierra de Guane, 219

Sierra de Guira, 253, 254

Sierra del Infierno, 235

Sierra de los Organos, I4

Sierra de Pan de Azucar, 43

Sierra de Paso Real de Guane, 219

Snake bird, ror

Snowy Egret, Ior

Solenodon, I96

Spanish Cedar, 192

Sphyrana barracuda, 5I 
Spiny lobster, 57

Spondias, 76

Sponges, 158

Spongia equina gossypina, ${ }^{58}$

"Sport," I34

Stegomya, 294

Stony Algæ, 64

Strombus, I77

Strombus pugilis, I02

Submarine light, 52

Subulina, 304

Supercilious Woodpecker, 195

\section{$\mathrm{T}$}

Tapia, Captain Edw., 46

Tarpon, II

Tectarius nodulosa, 165

Tectarius muricata, 165

Tellina, 66, I0I

Temperature effects, 213

Termite nests, 182

Thalassa, 57

Thrinax, 89

Thrinax wendlandiana, I7I, I75

Thysanophora, 304

Tide pools, 203-206

Tillandsias, I93

Toads, 286

Todi (Cuban), 92, 93

Todus multicolor, 92

Tolete (Punta), 144

Tomas Barrera, 9-I I

Toro fish, 120

Tournefortia gnaphaloides, 170

Tree Ducks, I0I, 201, 297

Tree Ferns, 72

Tree Toads, 27I, 273, 28I

Tretanorhinus variabilis, 247

Trichomanes, 32

Trunk-fish, 120

Tumbadero, El, 227, 234, 235

Typhlops lumbricalis, 25

Tylosurus, 202, 203
$\mathrm{U}$

Ungalia maculata, 24I

Urocoptis, 304

Urocoptis dautzenbergiana, 220

\section{V}

Vaginula occidentalis, 274

Valley of Viñales, 25-26

Veneridæ, ror

Viñales, 27

Vireo griseus, 195

Vittaria, 32

Vivero, ro

Vuelta Abajo, 14, 22 I

W

Wasps, 242

Weathering of rock, 162, 163

West Indian Mourning Dove, 218

White-Crowned Pigeon, 169

White-Eyed Vireo, I95, 284

White Ibis, IOI

Wright, Charles, 36

$\mathrm{X}$

Xiphigorgia anceps, $\mathbf{I} 57$

$\mathrm{Y}$

Yellow-Crowned Night Heron, IOI

Yellow-tail, 309

Yumuri Valley, 289

Z

Zenaida Dove, 218

Zenaida zenaida, 218

Zenaidura macroura, 218

Ziphidiopicus percussus, 195 


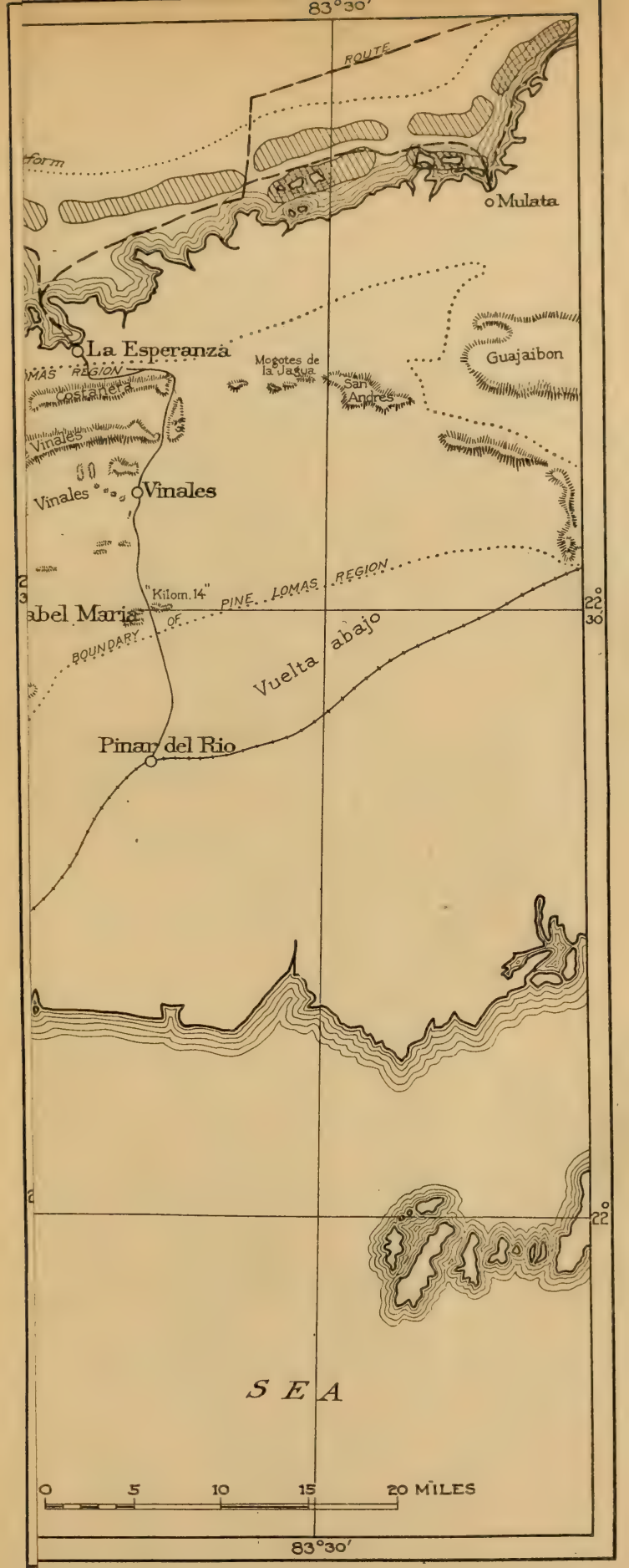





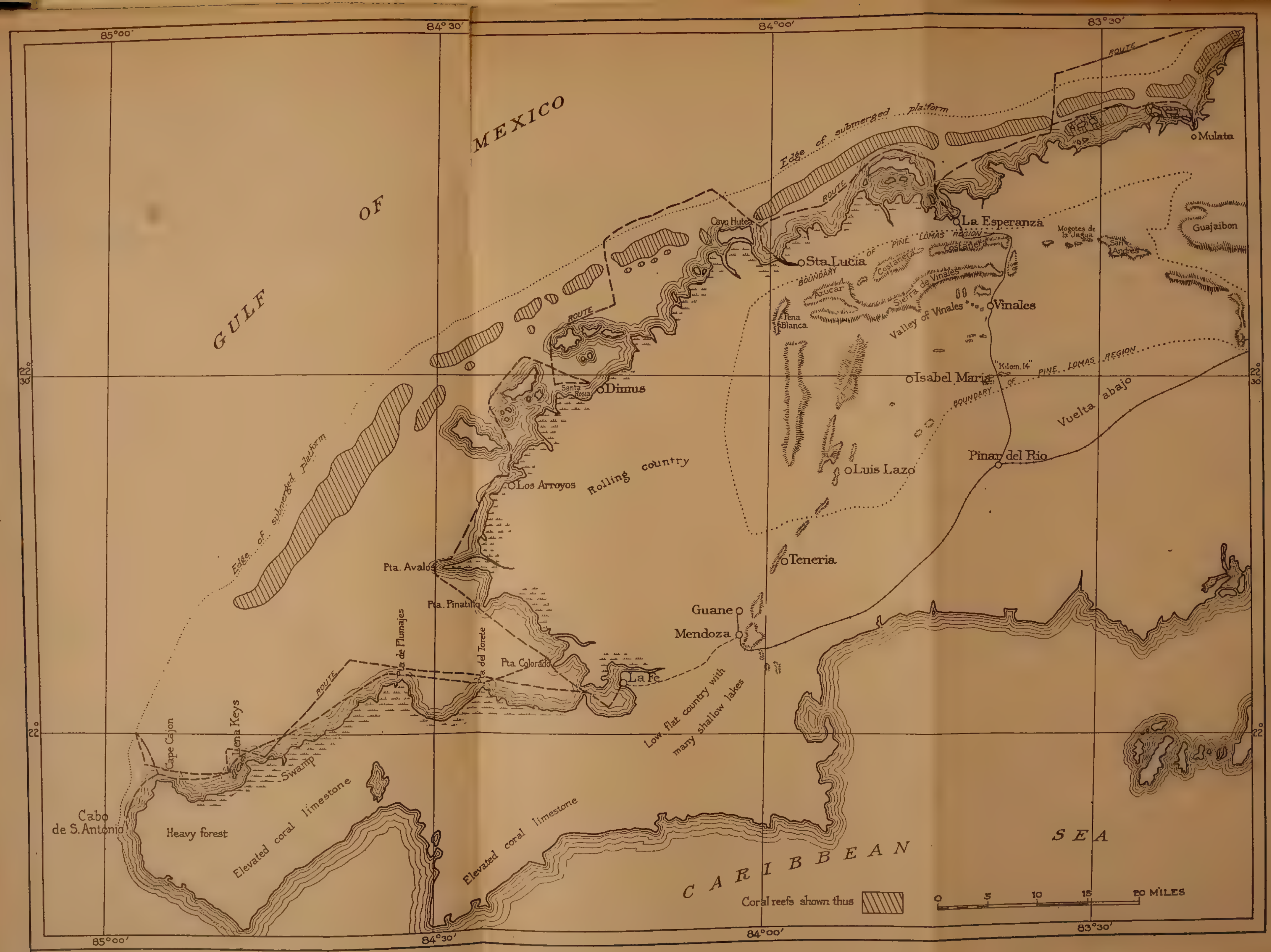










